\title{
POVIJEST REDOVNIŠTVA U SENJU I OKOLICI ${ }^{1}$
}

\author{
Mile Bogović \\ Gospićko-senjska biskupija \\ Senjskih žrtava 36 \\ HR 53000 Gospić \\ Josip Frković $^{2}$ \\ Župa Uznesenja BDM Senj \\ Ogrizovićeva 2 \\ HR 53270 Senj
}

\author{
UDK: 264(497.5Senj)(091) \\ Izvorni znanstveni članak \\ Ur.: 2021-07-10
}

Redovništvo se u Crkvi kao organizirana zajednica javlja nakon 313. godine, tj. nakon što je kršćanstvo dobilo slobodu. Na redovništvo u Hrvatskoj imali su utjecaj i Zapad i Istok, Zapadna i Istočna Crkva, tj. i Katolička i Pravoslavna Crkva. Redovništvo u Senju i okolici ostalo je vjerno Zapadu, ali od Istoka baštini glagoljicu i staroslavensko (starohrvatsko) bogoslužje zbog kojih je odigralo važnu ulogu lokalnih, nacionalnih pa i svjetskih razmjera. Benediktinci su došli na senjsko područje u 12. stoljeću i imali svoje opatije u Svetom Jurju, Senjskoj Dragi i Senju. Templari su došli u Senj u 12. stoljeću, franjevci stoljeće kasnije, a dominikanci u 14. stoljeću. Pavlinski samostani u Ljubotini (danas Spasovac) i Vlaškoj dragi (danas Sveta Jelena) datiraju iz 14. stoljeća, a njihova prisutnost u samom Senju zabilježena je 1634. godine. Oko 1622. godine u Senju su počeli na kratko vrijeme djelovati augustinci. Kada je riječ o materijalnoj potpori redovnicima, posebno su se istaknuli Frankopani, a nakon njih kralj Matijaš Korvin i njegovi nasljednici na prijestolju. Od ženskih redovničkih zajednica koje se javljaju kasnije, u Senju je zabilježeno djelovanje milosrdnica (u 19. i 20. stoljeću), sestara Presvetog Srca Isusova (u 20. stoljeću), sestara družbe "Immaculata" (u 20. stoljeću) i franjevki (također u 20. stoljeću).

Redovničke zajednice na ovom prostoru dale su veliki doprinos u vjerskom smislu, ali i u odgoju, širenju pismenosti i kulture, razvoju gospodarstva i graditeljstvu. Odlaskom sestara Presvetog Srca Isusova iz Senja 1997. godine prekinut je tisućljetni kontinuitet redovničkog života i rada u Senju i njegovoj bližoj okolici.

Ključne riječi: Senj, redovničke zajednice, samostan, crkva, Frankopani

${ }^{1}$ Mile Bogović, crkveni povjesničar i gospićko-senjski biskup u miru započeo je i većim dijelom pripremio tijekom 2020. godine rukopis knjige o kršćanstvu u Senju i bližoj okolici pod nazivom Senia Christiana. Taj rad u suatorstvu s nekadašnjim senjskim župnikom i dekanom te kanonikom Senjskog kaptola mons. Josipom Frkovićem (vidi dolje njegov životopis) planirao je objaviti u Senjskom zborniku, a potom kao posebnu knjigu. Budući da je Bogović umro 19. 


\section{Uvod}

Redovništvo se u Crkvi kao organizirana zajednica javlja nakon što je 313. godine Crkva dobila slobodu i u državi dobila zaštitnika. Postojala je opasnost da vjernici pomisle kako je u savezu Crkve i države ostvareno ono što Crkva naviješta. Tada su se mnogi svojevoljno isključivali iz tog društva i odlazili pojedinačno ili kao zajednica u osamu da svijetu reknu kako je naša domovina

prosinca 2020. godine, knjiga je ostala nedovršena pa zbog toga ovdje objavljujemo samo dio o redovništvu u kojem je Bogović najviše odmakao i, čini se, gotovo ga priveo kraju. U Predgovoru planirane knjige Bogović je napisao sljedeće: "Frković je najopširnije i najdetaljnije opisao senjske crkvene građevine i ustanove. On nije profesionalni povjesničar nego pastoralac. Poviješću se sustavno počeo baviti tek onda kada se zbog bolesti nije mogao baviti pastoralom. ... Svoj rad 'Senjski sakralni objekti' on je već 'učisto' natipkao tako da je pristupačan i iskoristiv onakav kako ga je on doradio. ... Njegov rad dao sam pretipkati još osamdesetih godina prošlog stoljeća kada sam bio ravnatelj Sakralne baštine u Senju gdje se čuva rukopis. ... Frković je opisao ustanove i građevine prije 40 godina i više. Mnogo toga je od tada napisano o onome o čemu govori njegov rukopis, a i ja sam osobno istim temama posvetio dobar dio svoga znanstvenog rada i došao do brojnih saznanja koja su Frkoviću ostala nepoznata. Senjski zbornik je do danas objavio mnogo novih radova kojima sam se, uz tu Frkoviću nepoznatu izvornu građu, obilno koristio. Zato sam odlučio na temelju svega toga Frkovićev rad temeljito preraditi i doraditi. U temama kojima sam se i sam dugo bavio nisam išao na prerađivanje i dorađivanje Frkovićevih tekstova, nego sam preuzeo svoje tekstove obogativši ih Frkovićevim dodacima. To su tekstovi o kaptolu, katedrali, gimnaziji, Bogoslovskom sjemeništu i teološkom učilištu, redovnicima. No, tada se više ne može govoriti o autorstvu jednog čovjeka, nego i njegovom i o mome." Na temelju molbe Uredništva, ovaj Bogovićev rad u rukopisu, obogaćen Frkovićevim dodacima, za objavljivanje u Senjskom zborniku priredio je te Sažetak i Zaključak napisao Franje Puškarić. Slikovne priloge priredila je i ustupila ravnateljica Gradskog muzeja Senj Blaženka Ljubović. Bogović i Ljubović zajedno su tijekom 2020. godine obišli lokalitete u Senju i okolici koji se spominju u ovom radu kao moguće lokacije obitavanja pojedinih redovničkih zajednica. Tako su 18. siječnja obišli lokalitete u Senju: Travicu, predio Velikih vrata, ostatke crkve sv. Franje i Pavlinski trg na kojem su bili crkva i samostan sv. Nikole. Dana 13. svibnja posjetili su lokalitet Abatovo i izvor "Voda" gdje je bila benediktinska opatija te tvrđavu Nehaj i temelje crkve unutar Nehaja za koju se smatra da je templarska. Osam dana kasnije, 21. svibnja, zajedno s konzervatorima ponovno su posjetili područje Abatova s ciljem da se pokrenu arheološka istraživanja kako bi se potvrdilo je li riječ o benediktinskoj opatiji. $\mathrm{Na}$ Veliku Gospu posjetili su Senjsku Dragu, a 16. rujna Rončević Dolac.

${ }^{2}$ Josip Frković rođen je u Ogulinu 21. rujna 1919. godine. Školovao se u Senju i Zagrebu, a za svećenika je zaređen u Zagrebu 11. srpnja 1943. godine. Kao mladomisnik imenovan je kapelanom u Otočcu, a dekretom od 26. kolovoza 1946. godine premješten je za župnika u Donjem i Gornjem Kosinju. Iz Kosinja je premješten za upravitelja župe u Donjem Pazarištu, Aleksinici i Klancu, a potom za upravitelja župe u Perušić odakle je upravljao također župom Kaluđerovac i vršio službu dekana Perušićkog dekanata. Godine 1963. premješten je za župnika u Senj. Imenovan je kasnije kanonikom Senjskog kaptola, članom Prezbiterskog vijeća Riječkosenjske nadbiskupije i tajnim komornikom pape Pavla VI. U nekoliko navrata bio je dekan Senjskog dekanata te 1966. godine dekan Jablanačkog dekanata. Umro je u Senju 26. veljače 1985. godine i pokopan je u kaptolskoj grobnici u Senju. 
na nebesima i da prema njoj putujemo. Tek u njoj je postignuće našeg konačnog cilja. Biti svjedok te vječne domovine, bitni je čimbenik svakog redovničkog života, ali se to svjedočanstvo daje na mnogo načina. To svjedočanstvo daje i Crkva u cjelini i svaki vjernik, ali kod redovnika je prisutno odricanje od dobara ovoga svijeta u jačoj mjeri nego se to od svakog vjernika traži.

Redovništvo je odigralo važnu ulogu u životu Crkve, ali i u životu društva općenito. Mnoge službe koje danas obavljaju državne ustanove (školstvo, zdravstvo), u srednjem vijeku obavljali su redovnici. To je u Senju vidljivo i u prvim stoljećima novog vijeka. U Senju su, na primjer, redovnici pavlini imali na brizi ugrožene putnike u Senjskom kanalu.

Oni koji se odriču dobara ovoga svijeta radi kraljevstva Božjega (vječne domovine) ne žive kako se kome svidi, nego imaju neka pravila života (regulu, propisani red) i zato se zovu redovnici. U prvom tisućljeću najproširenije pravilo dao je sv. Bazilije Veliki (+379.), a na Zapadu sv. Benedikt (547.). Prvi se obično zove otac istočnog (redovništva) monaštva, a drugi otac zapadnog redovništva (monaštva). Kod svih monaha zajedničko je beženstvo i osobno siromaštvo. Geslo je benediktinaca Moli i radi! (Ora et labora!). Njihove zajednice bile su doista radne zajednice u kojima je sudjelovalo i okolno stanovništvo i na taj način naučilo se moliti, ali i raditi. Nakon seobe naroda bilo je potrebno mačeve i koplja prekovati u lopate i motike i dati se na posao. Benediktinske zajednice bile su škole kako se radi; tako je Europa naučila raditi, a sv. Benedikt priznat kao zaštitnik Europe. ${ }^{3}$

U Crkvi je u skladu s kulturom i običajima nastalo više obreda, načina kako se slavi bogoslužje. Na Istoku je bilo više kultura pa je nastalo i više obreda; na Zapadu se nametnuo jedan obred (rimski ili latinski) jer je sav crkveni život bio u kulturnom smislu prožet jednom kulturom (rimskom ili latinskom). Nakon što se 1054. godine kršćanstvo podijelilo na pravoslavce i katolike, na Pravoslavnu i Katoličku Crkvu, svaki dio Crkve ima svoj posebni razvoj redovništva. Za naše krajeve, posebno za Senj, ta podjela imala je veliko značenje jer smo na granici Istoka i Zapada pa je na naš povijesni hod imala veliki utjecaj jedna i druga strana. Hrvatska se s knezom Branimirom (879.) definitivno okrenula prema Zapadu, ali mnogo toga baštini i od Istoka, kao npr. glagoljicu i staroslavensko (starohrvatsko) bogoslužje. Na tom području Senj je odigrao ne tek važnu lokalnu ili hrvatsku, već i ulogu svjetskih razmjera. Ključnu ulogu imalo je u tome upravo redovništvo. ${ }^{4}$

\footnotetext{
${ }^{3}$ Usp. S. KOVAČIĆ, 1980, 327-339; S. KOVAČIĆ, 2010, 97-112.

${ }^{4}$ Usp. S. KOVAČIĆ, 2008, 221-232.
} 
Istokje u pogledu redovništva ostao na onome što je bilo u prvom tisućljeću, a na Zapadu, u Katoličkoj Crkvi nastale su razne vrste redovništva. Na osnovi benediktinskog pravila nastadoše još cisterciti, kartuzijanci, trapisti, a nastala su i nova pravila. Revoluciju je unio sv. Franjo sa zavjetom općeg siromaštva (osobnog i siromaštva zajednice). To je okvir u kojemu nastaju tzv. prosjački redovi (franjevci, dominikanci, karmelićani), a poslije su došli i drugi. Svaki red ima svoj muški i ženski ogranak. Nastale redovničke zajednice bile kao neki kršćanski odgovor na potrebe društva, npr. jedni za školstvo, drugi za bolničku službu i sl. Veliku novost uveo je u crkvu u 17. stoljeću sv. Vinko Paulski kada je organizirao ženske redovničke zajednice i time aktivirao u društvenom smislu sposobnost žena da organizirano služe siromasima i bolesnima.

Sve glavne redovničke karizme našle su na plodno tlo i u Senju. U ovom radu pokušat ćemo današnjem naraštaju Senjana i svima koji su na bilo koji način sa Senjom povezani predstaviti život, rad i utjecaj tih redovničkih zajednica na društveni i vjerski život Senja i okolice u razdoblju u kojem su djelovale.

\section{Muške redovničke zajednice}

\section{a) Benediktinci ${ }^{5}$ - opatija sv. Jurja kraj Senja}

\section{Svjedočanstvo Senjske ploče}

Bizantski misionari su u vrijeme kada je Dalmacija bila pod Carigradom među Slavenima (Hrvatima) na tom prostoru uvodili narodni jezik u bogoslužje sa slovima (grafemima) za slavenske (hrvatske) glasove (foneme). Na Krku su se zarana razvila jaka hrvatska sela. Otuda je hrvatski misionar prenio tu bizantsku praksu na susjedno kopno. To kopno, Senj i okolina, bilo je svakako rekristijanizirano s otoka Krka. Tako je pokršćanjeno hrvatsko kopno dobilo ono što je bilo već ostvareno na Krku. S pravom se pretpostavlja da je i Senjska ploča - kao i Bašćanska - bila ugrađena u jednu glagoljašku redovničku crkvu i tako je otvorila poglavlje o prisutnosti redovnika glagoljaša u Senju. Ako u Baški poslije nalazimo u crkvi benediktince glagoljaše, logična je pomisao da ćemo isto naći i na susjednom kopnu u Senju. Bašćanska i Senjska ploča ne svjedoče za isto pismo, ali i za slične događaje. ${ }^{6}$

Rekristijanizacija Senja, dakle, dolazi s Krka. Nosioci misijskog djelovanja bili su redovnici (monasi) jer je biskupijski kler vezan uz službe unutar mjesne

${ }^{5} \mathrm{O}$ brojnosti literature koja govori o benediktincima u nas vidi M. TROGRLIĆ $-\mathrm{T}$. GALOVIĆ, 2018, 421-442.

${ }^{6}$ Usp. T. GALOVIĆ, 2015-2016, 327-340. 
Crkve. U vrijeme rekristijanizacije ti redovnici bili su bizantskog obreda koji je - nasuprot rimskom - uvodio narodni jezik u bogoslužje.

Na područje hrvatske kneževine i kraljevine dolaziloje zapadno redovništvo sa zapadnim (rimskim) obredom i latinskim jezikom u bogoslužju. Sredinom 11. stoljeća vlast hrvatskog kralja i jurisdikcija zapadnog patrijarha, pape, proteže se i na sjevernojadranske otoke gdje se uvodi rimski obred, ali ostavlja u bogoslužju narodni jezik i glagoljica kao pismo. Bašćanska ploča nam svjedoči o posjetu hrvatskog kralja Zvonimira Krku, ali i o presađivanju benediktinske regule na prostor gdje je bilo bizantsko (hrvatsko glagoljaško) monaštvo: iz benediktinske opatije u Otočcu u krčko redovništvo. ${ }^{7}$ Ista Ploča svjedoči također da je hrvatski kralj podržao taj susret zapadnog redovničkog pravila i bizantske prakse među Hrvatima. Takav susret dogodio se, naravno, bez fizičke prisutnosti kralja, ali uz njegovu podršku, na svim područjima koja su iz bizantske jurisdikcije ušla pod vlast hrvatskog državnog i pape kao duhovnog poglavara. Tako je glagoljsko stablo među Hrvatima zasađeno od Istoka raslo, cvalo i donosilo plodove unutar zapadnog kršćanstva, nakon što se ono raskolom 1054. godine odijelilo od onoga istočnog. Redovništvo je postalo čuvar i prenositelj bizantske prakse da se svakom (većem) narodu dadu bogoslužne knjige na njegovom jeziku. ${ }^{8}$

Zvonimir "v' dni svoe"9 dolazi na Krk sa zapadnim redovnicima iz Otočca ${ }^{10}$ i time otvara "benediktinizaciju" istočnog monaštva. Na Krku je najjači svjedok toga procesa Bašćanska ploča, a na kopnu Senjska glagoljska ploča. Na kopnu je u te dane nastala slična benediktinska glagoljaška zajednica. Zacijelo je to bio dulji proces tako da su se tragovi bizantskog monaštva još neko vrijeme osjećali. ${ }^{11}$

\footnotetext{
${ }^{7}$ Slično misli i Andrija Rački. On kaže da su u Otočcu benediktinci imali svoj samostan "koncem 11. vijeka, a možda i prije, da su iz njega potekli redovnici koji su sagradili samostan benediktinski u Baški te da je za vlade templara u Gackoj nestalo samostana i benediktinaca" (A. RAČKI, 1904, br. 31, 368). Međutim, A. Rački ne navodi nikakve konkretne izvore i potvrde za to. Suprotno stajalište o "Otočcu" vidi u: B. FUČIĆ, 1997, 114-129.

${ }^{8}$ O hrvatskim glagoljašima v. P. RUNJE, 1990. i P. RUNJE, 2012.

${ }^{9}$ Usp. T. GALOVIĆ, 2018, 265-285.

${ }^{10}$ Napominjemo da i nadalje to ostaje otvoreno pitanje, tj. gdje se nalazio "Otočac" Bašćanske ploče. Vidjeti: L. MARGETIĆ, 2000, 50-52.

${ }^{11}$ Iz svega rečenoga proizlazi da crkva koja je otkrivena pod temeljima Nehaja nije benediktinska, nego gradska, templarska pa opet gradska, posvećena zaštitniku grada sv. Jurju. Iz toga pak proizlazi da ni Senjska ploča ne pripada crkvi koja je otkrivena pod Nehajem. Senjska ploča je donesena iz neke druge, redovničke crkve. Moguće je da je to crkva u Abatovu, ali ako je najstarija redovnička zajednica ona u Kaštelini u Sv. Jurju, postavlja se pitanje kako je Ploča dospjela iz crkve deset km udaljene od Nehaja? Pa zar nije moguće da je Lenković koristio obrađeno kamenje iz udaljenih građevina, a crkve su bile najbolji izvor za obrađeni kamen?
} 
Senjska ploča nađena je na istom lokalitetu gdje je - pod zidinama Nehaja - jedna crkvica pa bismo poprijeko mogli riješiti pitanje da povežemo tu crkvu i Senjsku ploču. Lakša rješenja često nisu i dobra rješenja. Po dimenzijama crkve i Ploče ne bi bilo teškoća staviti Ploču na slično mjesto na kakvom je bila Bašćanska ploča u crkvi sv. Lucije. Treba ipak voditi računa da se na Trbušnjaku pri gradnji Nehaja našla hrpa kamenja koje je skupljeno po srušenim građevinama uokolo, a najviše po crkvama i samostanima gdje je bilo najkorisnije građe za jednu tvrđavu kakva je Nehaj. Nije bez temelja pretpostavka da je Ploča nastala u jednoj glagoljaškoj monaškoj (redovničkoj) zajednici, kao i ona u Baški. ${ }^{12}$ Crkva pronađena pod zidinama Nehaja bila je gradska, a ne redovnička crkva. U vrijeme rušenja crkava u prvoj polovini 16. stoljeća imali smo od redovnika na senjskom području benediktince, franjevce i pavline. Neće nikome pasti na pamet da pripiše Senjsku ploču franjevcima i pavlinima jer su oni nastali mnogo kasnije iza Senjske ploče, da ne govorimo o vremenu njihove pojave u senjskoj okolici. Ostaju nam još samo monasi glagoljaši koji su bili ovdje nakon raskola Crkve na pravoslavce i katolike 1054. godine. Monasi na otocima koji su prihvatili benediktinsku regulu (benediktinci glagoljaši) kao misionari djelovali su i na susjednom senjskom kopnu.

Tragom toga dobro nam dođu i neki dokumenti koji ostaju i dalje u nekim svojim postavkama nejasni. Jedan od njih je i darovnica kojom papa Inocent III. daje 1216. godine ugarskim hospitalcima samostan sv. Jurja u Kastelcu (de Castelluz) kraj Senja - jer je nenastanjen. ${ }^{13}$ Lokalitet se spominje u oporuci

Naime, ne samo da nema obrađenog kamena na mjestima gdje su bile u blizini crkve sv. Franje, sv. Petra i ona u Abatovu nego nema takva kamena ni u Sv. Križu u Senjskoj Dragi, ni u Kaštelini, odnosno na mjestu gdje je bila opatijska crkva sv. Jurja Lisačkog. Frančišković izrijekom kaže da se u zidovima Nehaja prepoznaje kamenje kakvoga nema u blizini Senja (J. FRANČIŠKOVIĆ, 1927, 491). Nije li i Ploča stigla s područja Sv. Jurja? Ovo razmišljanje korisno je uzeti u obzir u smislu poticaja za daljnja istraživanja.

${ }^{12} \mathrm{O}$ tome da su monaške (redovničke) zajednice prihvatile, prenosile i sačuvale glagoljicu u prvom tisućljeću pisao sam opširno u svojoj knjizi Glagoljica - bitna odrednica hrvatskog identiteta (Zagreb, 2019, 42-55).

${ }^{13} \mathrm{v}$. Cathalogus mss. Bibliothecae regiae scientiarum Universitatis Budapestensis, Budapest, 1894., tom. XIII, p. 94. Izvor nije toliko jasan da bismo mogli na temelju njega donositi velike i sigurne zaključke, ali u ovo škrto vrijeme u vrelima ne propuštamo nijednu nit da otkrijemo vezu krčkih glagoljaša s kopnom i Senjom. Šanjek, slijedeći Japundžića, misli da je tu riječ o bazilijancima u Senju $(1988,62)$. U registrima Inocenta III. u Vatikanskom arhivu nisam uspio naći papinu potvrdu. Ni Šanjek ne navodi izvor svoga podatka. Ipak je jasno da se radi o istoj stvari. To pokreće jedno novo, kod nas neriješeno pitanje: kada su samostani na našem priobalju postali "benediktinski", tj. kada je učinjen prijelaz od tipa prvotnog monaštva na reformirano redovništvo zapadnog tipa. Na Zapadu je taj proces počeo u 9. stoljeću. Kod nas je to išlo sporije, tim više što je utjecaj bizantske vlasti pogodovao čuvanju prijašnjih tradicija. Na Splitskoj sinodi 925. 


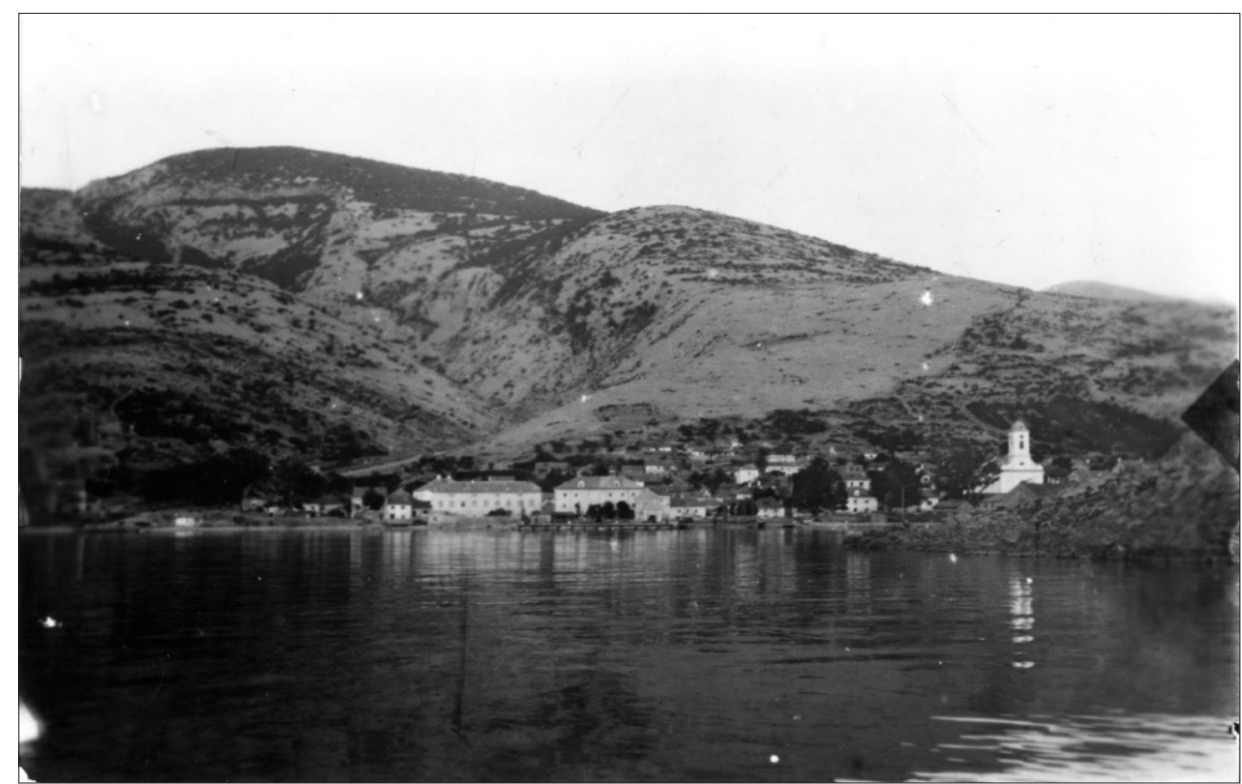

S1. 1. Sv. Juraj - pogled s mora (izvor: Gradski muzej Senj)

Desinje Androšića u kojoj ostavlja vinograd s komadom neobrađene zemlje u senjskom kotaru u mjestu koje se zove Costigline. ${ }^{14}$ Uz Kaštelinu tekao je potočić koji je često znao postati bujica, tako da je vode bilo "više nego dovoljno", kako kaže arheolog Miroslav Glavičić. ${ }^{15}$ Nakon 1340. godine opatija se gotovo redovito naziva Sv. Juraj Lisački (de Lisac), a u Sv. Jurju postoji brdo i Gradina koja se tako zove kao i otočić uz samo mjesto. Poslije će, dakako, biti i drugih dokaza da je u Sv. Jurju bila benediktinska opatija, ali nije bilo poznato da su počeci te opatije na području Sv. Jurja.

godine redovnicima je, kako je na drugom mjestu rečeno, dopušteno upotrebljavati "slavenski" jezik i pismo. Te redovnike su poslije nazvali benediktincima glagoljašima, a u stvari se radi o redovnicima koji su, u vrijeme kada se zapadno redovništvo obnavljalo po uzoru na zapadnu (benediktinsku) redovničku regulu, sačuvali svoje prijašnje običaje. Takva vrsta redovnika mogla je biti i u Jurandvoru i u Sv. Jurju kraj Senja u vrijeme nastanka Bašćanske, odnosno Senjske ploče.

${ }^{14}$ CD XI, 54. Costigli(o)ne na hrvatskom znači upravo Kaštelina. Kaštelina se spominje i 1379. godine u oporuci Senjanina Desinje koji ostavlja svoj vinograd "in districtu Segnie in loco vocato Casiglione" (CD XVI, 54). Ne može se iz teksta točno locirati gdje je taj "kaštelina", ali nije isključeno da je to upravo u Sv. Jurju.

${ }^{15}$ Spomenica Sv. Jurja, 46; usp. jedan peljar iz 1639. godine u kojem stoji "Suetti Iuray dobar porat za brode male i velike i za ribu loviti u kom je portu dobre slatke vode ke nigdar ne manka.... I oni je kloštar i criqua i nekoliko chuch zidanih pustich i ta je porat daleko od Segnia migl pet lattinskih" (R. LOPAŠIĆ, SHK, II, 1885, 211; LJ. KRMPOTIĆ, 1997, 322, 42). 
Nalazimo, dakle, monahe glagoljaše u Kaštelini (Sv. Jurju) 1216. godine, ali svakako da su tu mnogo prije te godine. Oni su imali u 14. stoljeću i svoju podružnicu ili priorat u blizini Senja (Abatovo), ali ta podružnica je mnogo mlađa od Senjske ploče. Imajući u vidu povijesni kontekst, Ploča je, dakle, najvjerojatnije nastala u Kaštelini (Sv. Jurju).

Jasno je da će svi uprijeti prstom u poteškoću jer se spontano javlja pitanje: Otkud u zidinama Nehaja? To je pitanje sebi postavio i Frančišković pa odgovara: A gdje je sada onaj silni materijal? Pogledamo li Nehaj-tvrđavu, vidjet ćemo na njemu različito kamenje. Na podnožju nalaze se blokovi od domaćeg, na mjestu nađenog kamenja, povrh toga dolazi tesani bijeli kamen. Odakle je ovaj? Domaći nije. Tvrđava se morala graditi navrat na nos, jer je neprijatelj bio pred vratima, nasrćući svaki čas otkad mu je Lika u rukama, pa nije bilo vremena da se nabavlja izvana bijeli kamen kad ima u tu svrhu dobrog i ovdje. ${ }^{16}$

Najbolji kamen je korišten za gradnju crkvi pa nije dovoljno reći da su crkve rušene samo zato da ne budu zaklon turskim napadačima, već i zato da se dobije kvalitetan kamen za gradnju Nehaja. Posebno je bio kvalitetan kamen benediktinskih crkava. Zato neće ni u Sv. Jurju, ni u Abatovu, ni u Sv. Križu ostati lako prepoznatljivih tragova opstojnosti tih opatija. Svakako treba računati s time da je za gradnju Nehaja korišten kamen i od opatije sv. Jurja Lisačkog (Sv. Juraj) i od podružnica u Abatovu te od opatijske crkve Sv. Križa u Senjskoj Dragi. $\mathrm{Na}$ tim mjestima je sve tako počišćeno da nije ostao "ni kamen na kamenu". Pronađeni su u zidovima Nehaja ostaci ploča iz porušenih pavlinskih crkava, a ne bi nas trebalo iznenaditi da otkrijemo u njima jasan znak da je onamo dospio i kamen iz benediktinske crkve sv. Jurja. Pretpostavljam da je to Senjska ploča, ali još nemamo stvarne potvrde te pretpostavke. Još je Đ. Szabo primijetio jednu krhotinu s desne strane ulaza u Nehaj s natpisom: "RELIGIONI SCTI PAULI" (reda sv. Pavla). ${ }^{17}$ Glavičić je pronašao u istim zidinama veliku slomljenu ploču Ivana Kosinjskoga koja također upućuje na pavlinsku crkvu, ali je teško pročitati ime crkve. Glavičić misli da je to crkva Sv. Duha (Spiritus), ali po svemu sudeći riječ je o crkvi Sv. Spasa (Salvatoris) ${ }^{18}$ jer je poznato da su Kosinjski bili povezani sa samostanom Sv. Spasa. U njihovoj crkvi Lacko Kosinjski podigao je oltar. Ako je, dakle, kamen iz uvale Ljubotina dospio u nehajske zidine, nema razloga da tim putem ne krene i kamen iz Kašteline (Sv. Jurja), a s njime i Senjska ploča jer je poznato da su benediktinske crkve bile često građene kvalitetnim kamenim kvadrima; redovito su po građevnom materijalu solidnije od pavlinskih.

\footnotetext{
${ }^{16}$ J. FRANČIŠKOVIĆ, 1927, 491.

${ }^{17}$ Hrvatski kulturni spomenici, 51.

${ }^{18}$ Usp. A. GLAVIČIĆ, 1981-1982, 88.
} 


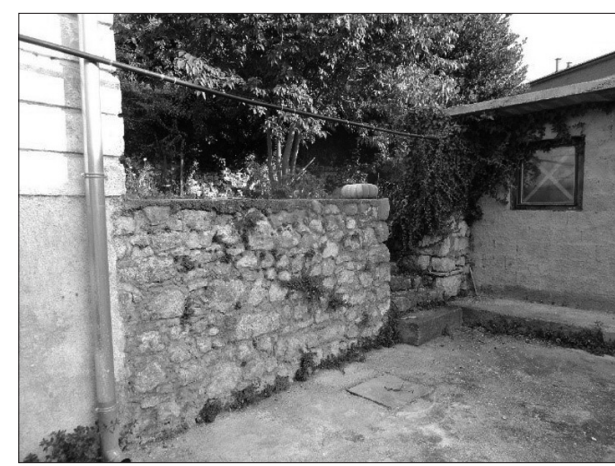

S1. 2. a) Župa sv. Juraj, župni stan (foto: B. Ljubović)

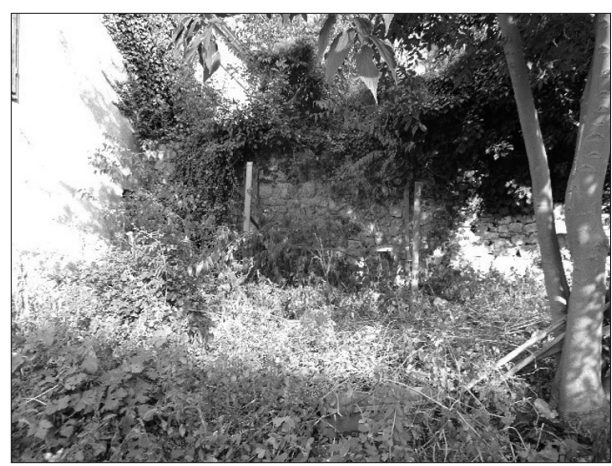

S1. 2. b) Župa sv. Juraj, ostaci zida starije građevine (foto: B. Ljubović)

\section{Sveti Juraj "Kaštelina"}

Da bi gore rečeno bilo razumljivo, treba ispraviti krivo mišljenje da su benediktinci u Senj došli tek nakon odlaska templara (1269.). Svakako je najjači dokaz za to Senjska ploča. Nakon toga tragovi benediktinske prisutnosti dosta su siromašni. Jednako su siromašni i oni na susjednom Krku. Ipak, nedvojbeni dokazi postoje počevši od 13. stoljeća.

Škrtost izvora navela je neke na krive zaključke. Tako je prošireno mišljenje da su templari dobili 1184. godine u Senju crkvu sv. Jurja i ondje sagradili svoj samostan u koji su se, nakon njihova odlaska, naselili benediktinci. Pozorno čitajući već odavno objavljene dokumente lako je uočiti da su benediktinci prisutni u senjskoj okolici za vrijeme templara, a zacijelo i prije. Zamka je bila i u tome što su templarska i benediktinska crkva posvećene istom svecu. Kako je već gore rečeno, na području Sv. Jurja živjela je benediktinska zajednica i to na prostoru koji narod zove Kaštelina. Andrija Rački tvrdi da se od benediktinskog samostana spasilo u selu Sv. Juraj nekoliko kamena što se nalaze uz župni stan. ${ }^{19}$

Sljedeći poznati dokument jasno pokazuje da su u isto vrijeme na području Senja živjeli i templari i benediktinci. Ni 20 godina nakon toga nalazimo kraj Senja siguran podatak o postojanju benediktinske opatije sv. Jurja. Naime, 4. svibnja 1245. templarski meštar Ivan de Metis presuđuje u pitanju granica posjeda u Gackoj između templara i monaha Sv. Jurja. Ondje postoje zemlje monaha Sv. Jurja i templarske zemlje; podijeljeno je tako da pola pripadne

${ }^{19}$ A. RAČKI, 1904, br. 31, 366. Rački inače misli da je u Sv. Jurju bio templarski samostan, a da su benediktinci došli u nj nakon odlaska templara. 
templarima, a pola monasima. ${ }^{20}$ Većina autora smatra da su benediktinci došli nakon templara pa ovdje ne uočava njihovu prisutnost iako se već po naslovima jasno vidi prisutnost i templara i monaha. Bio je tada preceptor Senja brat Ivan, preceptor Gacke brat Bernard, a opat Sv. Jurja je Ivan. Dok je preceptor izraziti templarski pojam, opat je poglavar jedne monaške (benediktinske) zajednice. Kako se u tekstu spominju monasi Sv. Jurja, jasno je da se ne radi o templarima, već o monasima (redovnicima benediktincima). $\mathrm{K}$ tome je u povelji riječ o razgraničenju između templara i monaha Sv. Jurja pa već iz toga proizlazi da ti monasi ne mogu biti templari. To pak znači da nisu došli nakon templara, nego su bili u njihovo vrijeme, a čini se i prije.

$\mathrm{O}$ prisutnosti monaha u vrijeme templara svjedoči i sljedeći podatak. Godine 1248. sporazumijevaju se templari s predstavnicima mletačke vlasti da će platiti štetu koju su imali krčki i rapski trgovci prigodom zauzeća i paljenja Senja 1239. godine, ali će i mletački podanici, stanovnici Baške, trebati dati odštetu redovnicima Sv. Jurja koje su opljačkali kad su ovi pred Tatarima prebjegli u Bašku. ${ }^{21}$ To nedvojbeno znači da u slučaju kada se spominje samostan, monasi ili opatija sv. Jurja ne može biti riječ o templarima, nego da su u senjskoj okolici benediktinci imali svoj samostan i u vrijeme dok su ondje gospodari bili templari. To znači da je otvoren put za istraživanje benediktinske prošlosti u Senju i okolici i prije templara - do Senjske ploče.

\section{Abatovo}

Dok se prisutnost benediktinaca u 13. stoljeću može vezati uz opatiju sv. Jurja na prostoru današnjeg mjesta Sv. Juraj, u 14. stoljeću ih nalazimo u

${ }^{20}$ Godine 1245. "Frater J(oannes) de Metis magister militie templi... nos vero igitur terram, quqm sanctus Georgius in Gecka habet, emendauimus. ... dimidiam partem templaribus et dimidiam monacis.... Temporibus. Actum est hoc et firmatum per consilium fratrum nostrorum et in tempore abbatis Johannis,..." (CD IV, 277)

${ }^{21}$ Š. LJUBIĆ, Listine, I, 76-77. Taj ugovor sklopljen je 25. travnja 1248. godine. Dana 3. svibnja iste godine određuje se način izvršenja odštete i tu je formulacija nešto drugačija. Naime, u prvom spisu stoji da templari neće tražiti nikakve odštete "exceptis de dampnis datis per homines Beske fratribus, qui fugiebant a Tartaris ex monasterio sancti Georgii". U slijedećem spisu se traži "ut fratribus milicie Templi, qui fugiebant a Tartaris, et monasterio sancti Georgii super dampnis datis eisdem per homines Veglie cognoscant" (Nav. dj. str. 78). Mile Magdić (1877, 53), a poslije njega i drugi, smatra da se radi o redovnicima templarima koji su pobjegli iz svog samostana sv. Jurja u Bašku. Imajući u vidu prethodni dokument iz 1245. godine može se i ovdje odijeljeno promatrati templare s jedne, a samostan sv. Jurja s druge strane. Tim više što je neuobičajeno da se templarske nastambe nazivaju samostan (monasterium). Oni imaju svoje kuće (domus Militiae Templi), a ne samostane. 


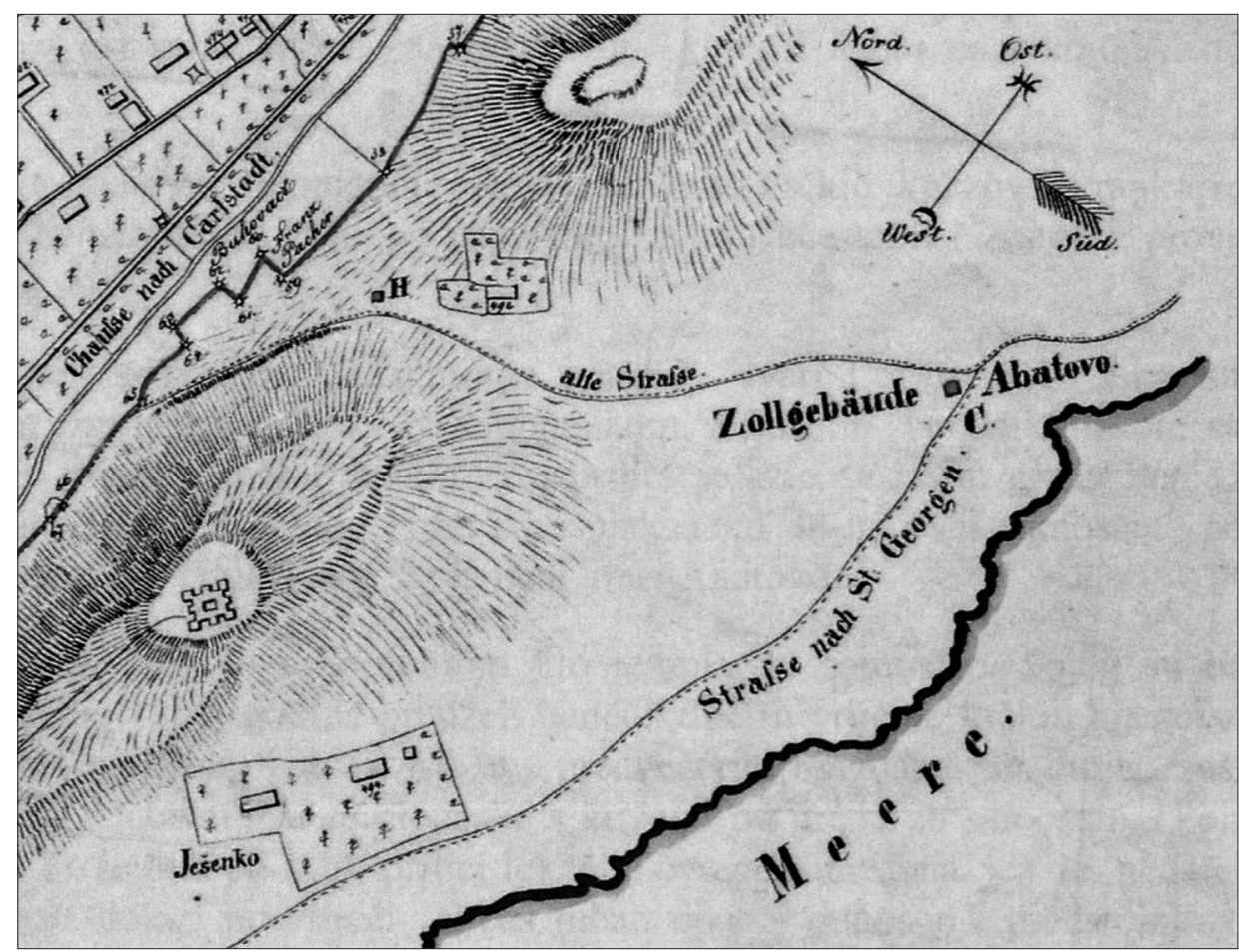

S1. 3. Karta iz 1853. s templarskim, a kasnije benediktinskim samostanom sv. Jurja na Abatovu ${ }^{23}$

neposrednoj blizini Senja, na lokalitetu danas zvanom Abatovo, ali pod istim imenom: opatija sv. Jurja. To je prikazao Josip Frančišković u svom radu Gdje je bila Opatija sv. Jurja. ${ }^{22}$ Njegova je teza: Opatija sv. Jurja kraj Senja je postojala, ali ne na području današnjeg Sv. Jurja, nego na području današnjeg lokaliteta Abatovo, oko 2 km od Senja, a ne oko 10 km koliko je udaljeno mjesto Sv. Juraj.

Za razumijevanje problema, treba reći da se benediktinske zajednice nazivaju opatije, priorati, monaške prepoziture, rezidencije, cele, hospiciji; da ne spominjemo one koje su bile privremena boravišta manjeg broja redovnika. Ova kraj Senja je jedna od njih, vjerojatno ona odmah do opatije. Izgleda da je i opat ondje neko vrijeme boravio, ali je opatijsko središte i dalje bilo u Sv. Jurju pa nije u Abatovu mogla biti samostalna zajednica ili opatija. Očito je također,

\footnotetext{
${ }^{22}$ J. FRANČIŠKOVIĆ, 1927, 489-492.

${ }^{23}$ Izvor: SENJSKI SAMOSTANI, Senj - moj virtualni muzej, URL: https://www.facebook. com/2060876087281881/photos/a.2954223551280459/2954228464613301
} 
da su odnosi između samostana i knezova bliski jer govore o svom samostanu (monasterium nostrum).

$\mathrm{Za}$ postojanje benediktinske zajednice u neposrednoj blizini Senja Frančišković navodi dva sigurna izvora. To je dokument iz 1314. godine gdje je riječ o sajmu u Senju i Statut Senjskog kaptola koji spominje opatijske crkve Sv. Križa i sv. Jurja iz čega se vidi da je crkva sv. Križa dalja od Senja nego opatijska crkva sv. Jurja. Ako je to tako, onda treba tu crkvu i samostan tražiti bliže Senju. U tom traženju Frančišković je vidio da je ta crkva mogla biti u Abatovu. U dokumentu iz 1314. godine riječ je o dogovoru između Rabljana i krčkih i senjskih knezova Dujma i Fridrika. Između njih vodio se neki spor (možda zbog Jablanca). Knezovi su Rabljanima predložili najpogodnije mjesto i termin. To je samostan sv. Jurja Senjskoga na blagdan sv. Jurja kada se ondje okuplja veliko mnoštvo naroda. ${ }^{24} \mathrm{Nema}$ sumnje da se ovdje radi o samostanu koji je u neposrednoj blizini grada Senja.

Drugi dokaz da je samostan blizu Senja Frančišković s pravom nalazi u Statutu Senjskog kaptola. U Statutu iz 1340. godine ${ }^{25}$ spominju se opatije sv. Križa i sv. Jurja. Prema tim odredbama jasno je da je opatijska crkva sv. Jurja bliža Senju nego ona sv. Križa. Naime, kada kaptol ide za blagdane u Sv. Križ treba opatija senjskom arhiđakonu poslati konja, a opatiji sv. Jurja to ne treba. Onamo se ide u procesiji i s križem, i u predvečerje i na sâm dan. Sve to govori da je samostan sv. Jurja blizu Senja, bliže nego je Sv. Križ. Kad bi se u spomenutim izvorima govorilo o samostanu na području današnjeg Sv. Jurja, postali bi gornji govori nerazumljivi. ${ }^{26}$

Frančišković se dao na traženje lokaliteta u blizini Senja koji bi bio najpogodniji za jedan benediktinski samostan i tako je došao do Abatova. Da navedemo Frančiškovićeve riječi: "U blizini Senja, pokraj Nehaja ispod brda Trbušnjak na cesti prema Sv. Jurju nalazi se uvala zvana Abatovo. Ovaj naziv opravdava položaj samostana sv. Jurja, a od senjske stolne crkve Abatovo je

${ }^{24}$ Godine 1314. "monasterium nostrum Sancti Georgii de Segna" (Š. LJUBIĆ, Listine, I, 281).

${ }^{25}$ Ustalilo se mišljenje da je Statut donesen 1380. godine. Mislim da sam donio dovoljno dokaza da je on donesen 1340. godine, ili možda godinu prije ili poslije (M. BOGOVIĆ, 1988, 25-26). Tekst statuta objavio je Sladović (M. SLADOVIĆ, 1856, 182-186) i ovdje se navode tekstovi prema tom izdanju.

${ }^{26}$ Frančišković je dobro uočio da su benediktinci opatije sv. Jurja imali svoju crkvu i samostan u Abatovu, ali se ne možemo složiti s njime kada isključuje postojanje opatije na području današnjeg Sv. Jurja, kao što se ne slažemo ni s njegovom tvrdnjom da su benediktinci crkvu i samostan u Abatovu naslijedili od templara. Postojala je opatija u Sv. Jurju, a templari su dobili crkvu na današnjem Nehaju, a ne u Abatovu. 


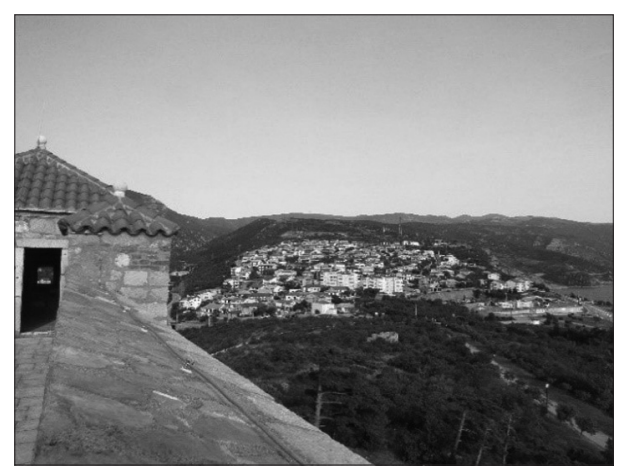

Sl. 4. Pogled s Nehaja prema Trbušnjaku (foto: B. Ljubović)

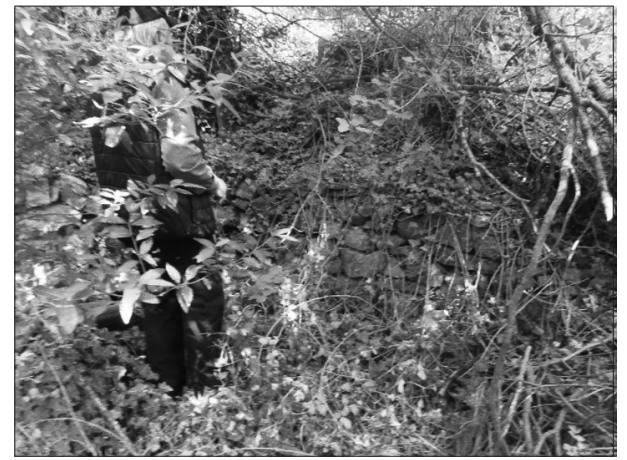

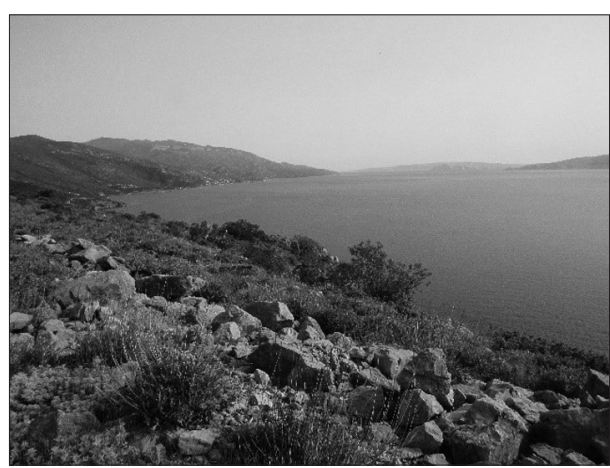

Sl. 5. Pogled s Trbušnjaka prema Sv. Jurju (foto: B. Ljubović)

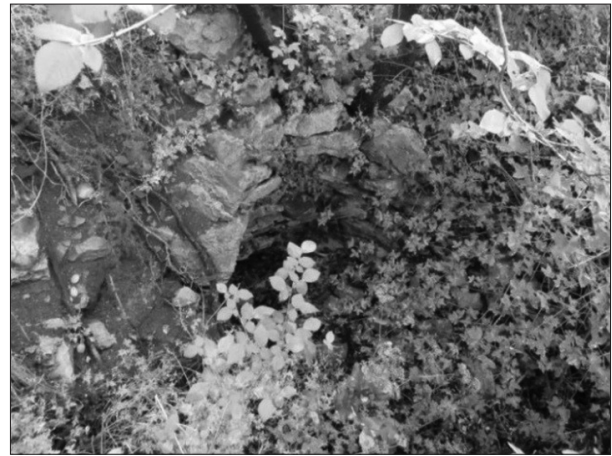

Sl. 6. a) i b) Mile Bogović na lokalitetu Abatovo; ostatci zidova i bunara, 14. svibnja 2020. (foto: B. Ljubović)

udaljeno jedva četvrt sata i zato se je ovamo mogla voditi procesija u predvečerje $i$ na dan sv. Jurja. No, moglo bi se prigovoriti da osim naziva Abatovo nema nikakvog drugog znaka, koji bi svjedočio da je u Abatovu bila crkva i samostan. (Sačuvana je samo jedna cisternica za koju narod veli da potiče iz vremena grčkih).

Ovaj prigovor lako otpada kad znademo da je general Lenković dao porušiti sve kuće, crkve i samostane izvan zidina gradskih, da se neprijatelji Turci nemaju gdje zadržavati i sakrivati, pa je tako porušen (ukoliko nije već prije) i samostan sv. Jurja sa crkvom u Abatovu."27

Na prostoru Abatova u drugoj polovici 20. stoljeća nastalo je naselje, a i danas jedna od glavnih ulica zove se Abatovo, što nas podsjeća na nešto slično

${ }^{27}$ J. FRANČIŠKOVIĆ, 1927, 491. 

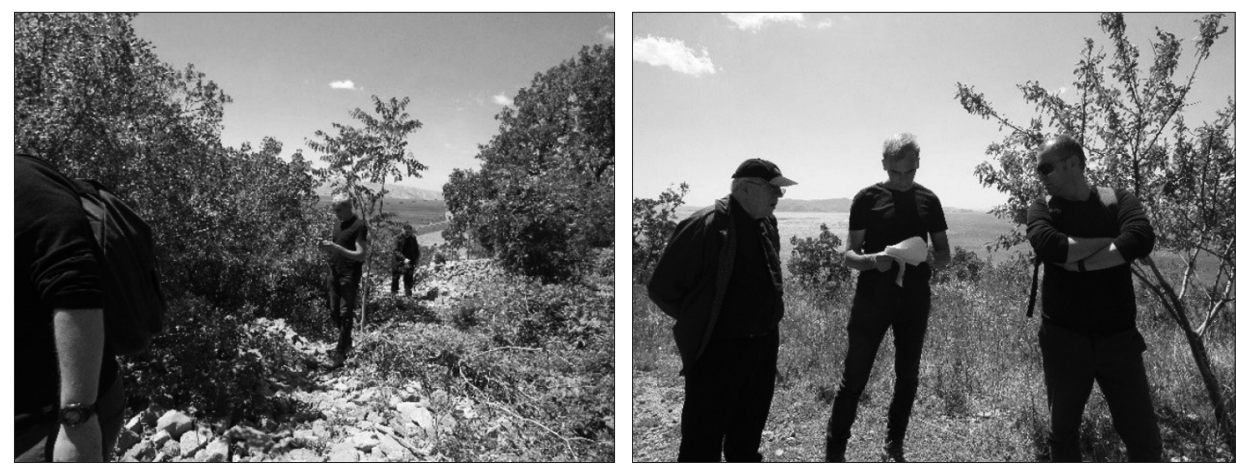

Sl. 7. a) i b) M. Bogović s konzervatorima Nediljkom Vančom i Vinkom Madiracom na lokalitetu Abatovo, 21. svibnja 2020. (foto: B. Ljubović)

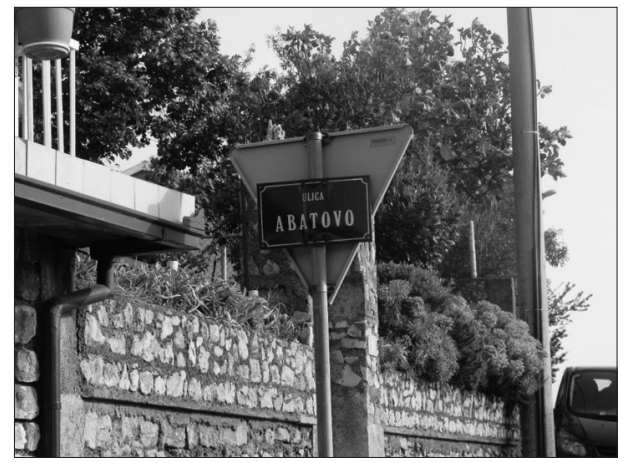

Sl. 8. Ulica Abatovo u naselju Trbušnjak u Senju, 13. svibnja 2020. (foto: B. Ljubović)

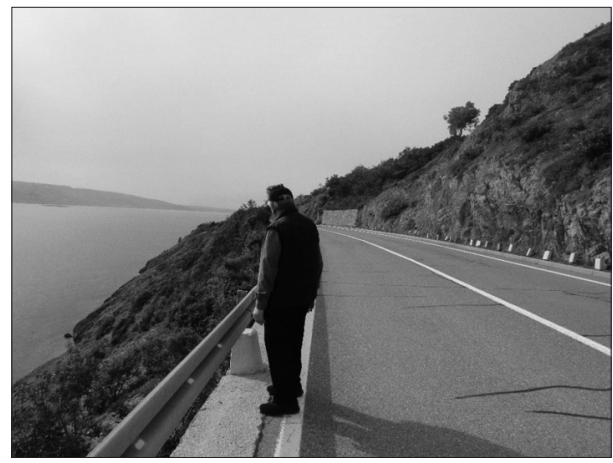

S1. 9. Pogled na lokalitet "Voda" - izvor potočića u more, 13. svibnja 2020.

(foto: B. Ljubović)

kao opatija (Abbatia). U vrtu je do nedavno stajala kuća poljarica u suhozidu i tzv. "grčki" bunar. Tuda je prolazila stara rimska, a kasnije srednjovjekovna cesta koja je više služila karavanskom nego kolskom prometu. Cesta je išla preko Trbušnjaka ispod Hrmotina za Sv. Juraj i dalje uz more prema Dalmaciji.

Tu se i danas nalaze ostaci brojnih terasa i ogradnih zidova koji su s vremenom zapušteni i propali. Ovdje se na površini i pod zemljom našlo fragmenata rimske i srednjovjekovne keramike, opeke, glaziranih posuda i dr. Sve to govori da su tu djelovale mnoge radne ruke koje su često hvatale radne instrumente $\mathrm{i}$ često se sklapale na molitvu. Ta redovnička nastamba imala je svoje najsvjetlije trenutke sredinom 14. stoljeća, da bi se koncem istog stoljeća ili početkom idućega ugasila kao redovnička zajednica. Ostalo je opatijsko 

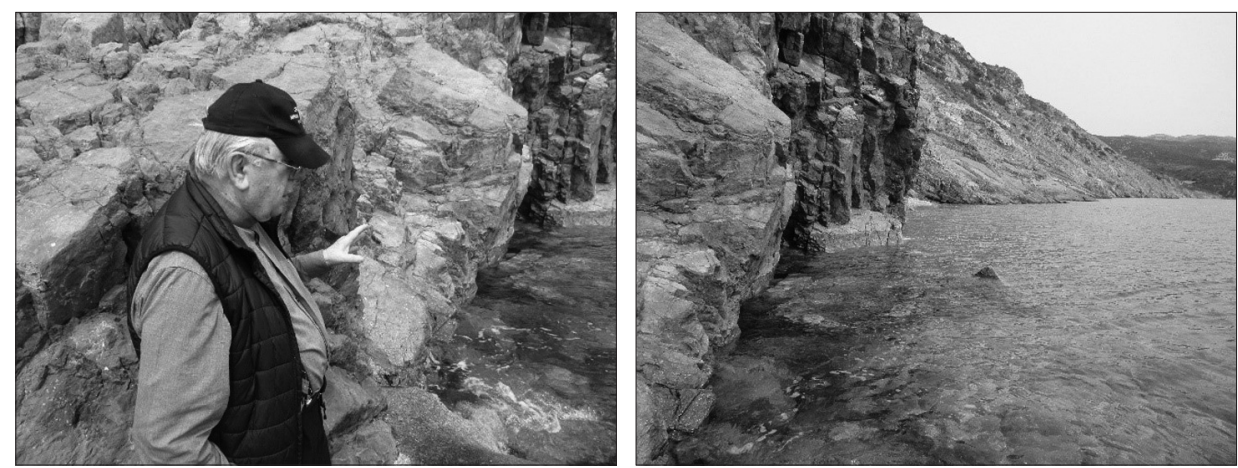

Sl. 10. a) i b) M. Bogović na lokalitetu "Voda", 14. svibnja 2020. (foto: B. Ljubović)

imanje koje su kao nadarbinu dobivali najprije komendatarni, a poslije naslovni opati koji nisu bili iz benediktinskog reda. Crkva je po svoj prilici postojala i dalje, kao i samostanske kuće jer su zemlju obrađivali kmetovi ili koloni koji su komendatarnim opatima trebali dati dio prihoda. Zadnji od njih bio je otočki biskup Vinko de Andreis koji se još 1515. godine neuspješno trudio da sačuva cjelinu opatijske nadarbine. Život je ondje bio sve do oko godine 1522. kada su Turci spalili i porobili sve kuće, crkve i samostane izvan gradskog bedema, a senjski kapetan Ivan Lenković dao preostalo oko 1540. godine do temelja sve od reda porušiti da se u njima ne bi utvrdio neprijatelj.

Nakon što sam i sâm i s arheolozima dobro pregledao prostor Abatova, shvatio sam još bolje da je Josip Frančišković u svom radu Gdje je bila Opatija sv. Jurja? dobro procijenio da je u Abatovu mogla biti jedna benediktinska ustanova. Ono je kud i kamo prikladnije nego brdo na kojemu je danas tvrđava Nehaj. Mjesto današnjeg Nehaja bilo je prikladno za okupljanje, ali ne i za život i za rad. Benediktinske kuće građene su na mjestima gdje ima dosta obradive zemlje, uvijek uz vodu ili izvor. U Abatovu imamo zdenac i potočić koji danas izlazi podzemno u more i taj lokalitet na moru naziva se službeno "Voda". ${ }^{28}$

$\mathrm{Na}$ širokom prostoru između gradskog zaštitnika sv. Jurja na mjestu današnjeg Nehaja i opatijskog samostana u Abatovu bilo je dosta mjesta za narodna okupljanja i za sajmove. Očito da su gospodari Senja krčko-senjski knezovi bili u dobrim odnosima s opatijom, a i svetkovina sv. Jurja za Senjane bila je narodni zbor. Opat je uživao veliki ugled, tim više što su biskupi bili

${ }^{28}$ Ante Glavičić kaže da na području grada Senja nisu pronađeni izvori žive vode. Izuzetak u tome predstavlja Senjska Draga i izvori na samoj obali (u moru ispred bivše crkva sv. Ambroza i južno prema Spasovcu, južno od Abatova $(1968,39)$. Očito je da se radi o mjestu o kojem ovdje govorimo. 
često odsutni jer su ih kraljevi i pape slali na razne strane kao svoje poslanike. Moguće je da je već te godine opat bio Bernard kojega je Senjski kaptol izabrao 1333. godine za biskupa, a sve crkvene i civilne vlast i u Senju jednodušno su to prihvatile. No, i pored toga Bernard se nije mogao održati.

\section{Opat i biskup Bernard}

U to vrijeme avinjonski pape, ostavši bez sigurnih izvora prihoda u Italiji, izgrađivali su posebni sustav izdržavanja papinske kurije na način da je stvorena jaka mreža u cijelom katoličkom svijetu po kojoj su beneficirani dostojanstvenici i ustanove trebali papinskoj komori davati propisani iznos. Jednako tako je planski rađeno da pojedine crkvene institucije dođu u ruke onima koji su zasvjedočili svoju vjernost središnjici Crkve. To se osjetilo i u Senju. Za vrijeme biskupa Jurja (+1332.) papa Ivan XXII. dogovorio se s njime da nakon njega samo papa ima pravo imenovati nasljednika. Kad je Juraj umro, papa je 4. siječnja 1333. godine imenovao njegovim nasljednikom augustinca Ivana iz Pise i poslao ga da preuzme upravu Senjske biskupije. U međuvremenu umro je papa Ivan XXII., a naslijedio ga Benedikt XII. No, u Senju su bili još brži pa je po dotadašnjem običaju i pravu ${ }^{29}$ Senjski kaptol izabrao za Jurjeva nasljednika Bernarda, opata Sv. Jurja kraj Senja. Nadležni splitski metropolit potvrdio je izbor i Bernard je posvećen za biskupa i preuzeo je upravu biskupije. Podršku Bernardu dali su i krčki i senjski knezovi Dujam i Bartol. Međutim, papinski kandidat Ivan krenuo je prema svojoj biskupiji i došao do Raba. Ondje je saznao da ga u Senju na žele primiti jer već imaju Jurjeva nasljednika. Ivan se, pomognut rapskim biskupom, koristio svim crkvenim kaznama, izopćenjem krivaca i zabranom svake službe Božje u Senju (interdiktom), ali nije polučio uspjeh jer se sav Senj našao oko Bernarda. Uz njega su bili dostojanstvenici kaptola: Jakov arhiđakon, Juraj arhiprezbiter i Ivan primicer s ostalim kanonicima, zatim oba opata - Sv. Jurja opat Mihovil i Sv. Križa opat Franjo, plemići David, Jakov i Vid te gradski suci Kresola i Raužan. Svi su oni otvoreno stali u obranu Bernarda i usprotivili se prihvaćanju biskupa Ivana.

${ }^{29}$ Patronatsko pravo imenovanja biskupa dobio je "apostolski kralj" sv. Stjepan. Ugarski kraljevi su to pravo svojatali kao nasljednici sv. Stjepana. Rimska kurija je nekada to prihvaćala a nekada pravo ograničavala na osobno pravo sv. Stjepana. Hrvatsko-ugarski kralj Ladislav Kumanac izdao je 11. lipnja 1289. godine povelju kojom potvrđuje Krčkim knezovima u biskupijama Krbavskoj i Senjskoj (CD VI, 653-656); usp. M. BOLONIĆ, 1973, 232-234, 242). U ovom slučaju nije jasno koliko je to bio pravni temelj za izbor Bernarda, ili se oslonilo na pravo kaptola. Prema citiranom pismu papa Benedikta XII. više je vjerojatno da se kaptol oslanjao na svoje, a ne na pravo Krčkih knezova. 
Ivan se potužio papi Benediktu XII., a ovaj je imenovao kardinala Petra da osobno pokaže pisanu papinsku odluku i izvidi prilike. Koliko se dade iščitati iz pisma, kardinal se koristio sličnim sredstvima kao i biskup Ivan, ali nije ni on imao naročita uspjeha. Tako je to trajalo više od tri godine. Novi papa potvrđen je tek 1335. godine pa se nije mogao odmah zauzeti za slučaj i pomoći Ivanu iako se dobro razumio u problematiku jer je on cistercit (reformirani benediktinac). Kao papa radio je na obnovi redovništva. Apostolskim pismom 1336. godine $u$ buli (svečanom pismu) "Summi magistri", koju se često naziva "benediktina", temeljito preuređuje ustrojstvo reda: samostani su podijeljeni u 32 provincije, opati se trebaju naći na kapitulu svake treće godine, a svaki dvadeseti monah treba završiti sveučilišne nauke. Vjerojatno je ta obnova zahvatila i opatiju sv. Jurja. Senjski slučaj papa je izravno preuzeo tek početkom 1338. godine. On je 7. siječnja 1338. godine odredio provedbeno povjerenstvo u kojemu su bili rapski i osorski biskup te opat Sv. Petra u Rabu. ${ }^{30} \mathrm{U}$ tom pismu iznosi pojedinosti od kojih su neke navedene i u gornjem tekstu. $\mathrm{U}$ isto vrijeme pisao je splitskom nadbiskupu ${ }^{31}$ i senjskim vjernicima ${ }^{32}$ da prihvate i podrže biskupa Ivana. Nije nam poznato što se sve dogodilo da do tog prihvaćanja dođe, ali ono je svakako došlo jer nakon toga spominje se kao upravitelj biskupije biskup Ivan. Biskup Ivan pokazao se sposoban i dobar pa je nakon Senja dobio Splitsku nadbiskupiju. ${ }^{33}$

Izgleda da mir nije uspostavljan samo po kaznama. Bernardu je svakako oduzeta uprava biskupije, ali se poslije mogao vratiti na čelo opatije. No, i za vrijeme njegove službene uprave, opatiju je ustvari vodio papin kandidat Nikola, rodom iz srednje Italije (biskupija Frosinone). Bernard je umro 1352. godine. ${ }^{34}$ Naslijedio ga je opat Nikola koji je i prije bio stvarni njezin upravitelj. Dakle, na samo biskupija, nego je i opatija dobila upravitelja izvana (s Apeninskog poluotoka).

Nakon Bernardove smrti nastali su nemiri slični onima nakon 1333. godine jer se nametnuo za opata neki Martin iz Krčke biskupije. I on je imao podršku među senjskim građanima, a posebno ga je podržavao neki Vidonja (vjerojatno

${ }^{30} \mathrm{CD} X, 363-367$.

${ }^{31} \mathrm{CD} X, 367-369$.

${ }^{32} \mathrm{CD}$ X, 369-371.

${ }^{33}$ O biskupu Ivanu v. M. BOGOVIĆ, 2017, 38-39.

${ }^{34}$ Nikola se spominje još za života Bernardova kao opat 13 . kolovoza 1349. kada je platio Apostolskoj komori "33 florenos auri et terciam partem" ("frater Nicolaus abbas monasterii s. Georgii de Lissa" (CA I, br. 174; II, br. 1248), ali se godinu dana poslije kaže da je postao opat nakon smrti Bernardove (1352. "fit abbas 4. Julii 1452. "per obitum Bernardi" (Camera apostolica, dalje: CA, I, br. 174). 
onaj koji se prije naziva Guido/Vid). ${ }^{35}$ Nemiri nisu zadobili razmjere slične onima nakon smrti biskupa Jurja jer je sada na kormilu biskupije kao biskup bio papin kandidat Portiva (Protiva). Iako ni ova intervencija protiv volje vrhovnog crkvenog poglavara nije imala u konačnici uspjeha, iz nje se vidi povezanost senjske općine i njezinih gospodara s opatijom sv. Jurja. Opat Nikola bio je 1354. godine premješten za opata $u$ lokrumski samostan u Dubrovačkoj biskupiji, a na čelo opatije sv. Jurja u Senj došao je Kuzma iz opatije sv. Kuzme i Damjana, iz Zadarske nadbiskupije. ${ }^{36}$

Kako je prije spomenuto, biskup Ivan pokazao se sposoban i dobar pa je nakon Senjske biskupije dobio Splitsku nadbiskupiju. Najzapaženiji njegov uspjeh je donošenje Statuta Senjskog kaptola. U njemu nema više govora o pravu Kaptola na izbor novoga biskupa. Nama je Statut ovdje važan i zbog toga što se u njemu govori o opatiji sv. Jurja.

\section{Sveti Juraj Lisački (de Lisac)}

Nakon nemira u Senju vezanih uz nasljednika biskupa Jurja (+1332.) i donošenja kaptolskog statuta 1340. godine, javlja se opatija pod novim nazivom: opatija sv. Jurja Lisačkog (de Lisac). Uz Sv. Juraj postoji jedno brdo koje se zove Lisac, a i otočić nasuprot crkve sv. Filipa i Jakova ima isti naziv. Neki misle da izraz dolazi od stare Lopsice koja je tu bila u starom vijeku, ali to nam ovdje nije posebno važno. Prvi put za opatiju sv. Jurja naziv "Lisački" (de Lesac) nalazimo 24. kolovoza 1343. godine kada Andrija de Orlandis, monah samostana sv. Jurja Lisačkog moli Svetu Stolicu da dobije pravo glasa u svojoj opatiji. ${ }^{37}$ Poslije toga će se opatija i opati gotovo redovito zvati Lisački (de Lisac). Glavnina posjeda opatije bila je na području današnjeg Sv. Jurja pa je i naselje dobilo naziv po

${ }^{35}$ Dana 2. srpnja 1352. godine papa Klement VI. naređuje da svi prihvate opata Nikolu. Još za života opata Bernarda papa je zadržao za sebe imenovanje nasljednika i imenovao je Nikolu. Međutim, neki Videnja iz Senja, podržan još nekim građanima, sprječavao je preuzimanje opatije od strane Nikole i podržavao Martina iz benediktinskog samostana Krčke biskupije. (Archivio Segreto Vaticano, dalje: ASV, Reg. Vat., vol. 212, f. 359rv)

${ }^{36}$ Godine 1355. papa Inocent VI. kaže da je opata Nikolu premjestio za opata Sv. Marije u Lokrum, Dubrovačke biskupije, a za opata sv. Jurja Lisačkog imenuje Kuzmu, monaha iz samostana sv. Kuzme i Damjana, Zadarske biskupije (Reg. vat. 228, f. 40r); 4. veljače 1360. godine Kuzma podmiruje pristojbe Kuriji: 16 florena i 16 solidi za prethodnika Nikolu i 8 florena, 11 solidi i 4 dinara za sebe (CA, I, br. 272; II, br. 554 i 555); "Kuzma, abbas monasterii s. Georgii O.S.B." 1355. godine platio je istu svotu za sebe i za svojega predšasnika Mihovila, dok su se komendatari samostana "s. Georgii de Lisac Segniensis" u početku 16. stoljeća obvezivali na 50 for.

${ }^{37}$ Andreas de Orlandis ... monachus monasterii s. Georgii de Lisetz (v. Arpad BOSSANY, Regesta supplicantionum, Klement papa 1342-1352, Budapest, 1916. pod gornjim datumom). 

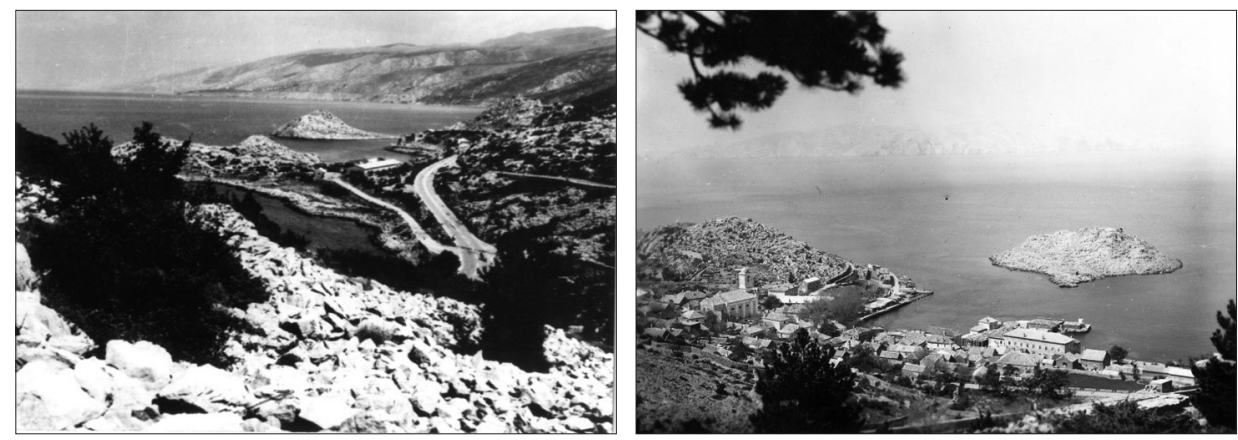

Sl. 11. a) i b) Sv. Juraj - pogled na otočić Lisac (izvor: Gradski muzej Senj)

opatiji (Sv. Juraj). Početkom 14. stoljeća (1318. godine, za što imamo podatke) javlja se već i Sv. Juraj kao posebno naselje.

Kada u spomenicima nalazimo opatiju sv. Jurja de Lisaz, de Lisacz, de Lisazio in Liscacz, de Lissetz, de Lissia ili de Lisac, kaže se da je taj Lisac bio u Senjskoj biskupiji. Tako je npr. splitski nadbiskup Andrija godine 1388. globio opata Sv. Jurja (abbatem S. Georgii de Lisac Seniensis dioecesis) što nije došao na sinodu u Splitu. Na nekoj povelji Nikole Frankopana iz 1426. godine svjedok je Josip, opat Sv. Jurja Lisačkoga, Senjske biskupije. Isto tako je papa Nikola V. (1447. - 1455.), kada je htio dokinuti benediktinsku regulu i opatsku čast u samostanu sv. Mihovila i sv. Lovre na Krku, delegirao za taj posao Bartolomeja, opata Sv. Jurja Lisačkoga u Senjskoj biskupiji. Istom oznakom služi se Rimska kurija više puta.

Dodatak de Lisac (Lisački) upućuje da je u to vrijeme došlo do nekih promjena u samoj opatiji. Ako je opat neko vrijeme i boravio privremeno u Abatovu, on se vratio u Sv. Juraj. Mogle su biti posrijedi i kakve crkvene sankcije zbog ponašanja članova reda povodom imenovanja opata Bernarda biskupom i njegova uklanjanja s biskupske stolice. Mogao je utjecati i poziv kralja Karla IV. senjskim benediktincima da dođu u Prag i ondje otvore glagoljaški samostan. ${ }^{38}$ Ako se više senjskih benediktinaca ${ }^{39}$ odazvalo, vjerojatno ih je premalo ostalo da drže i podružnicu u Abatovu i središnjicu u Sv. Jurju pa je izabran Sv. Juraj kao pogodnije mjesto, što on doista i jest. Glavnina opatijskih posjeda bilo je na tom prostoru, što potvrđuje i dokument iz 1515. godine. U Abatovu bila je i dalje crkva koja je pripadala opatiji sv.

${ }^{38}$ M. BOGOVIĆ, 2019, 88-94. U to vrijeme (1353.) nastaje u Senju u crkvi sv. Kuzme i Damjana Kirinov ili Lobkowiczov psaltir.

${ }^{39}$ Usp. T. GALOVIĆ, 2016, 139-150. 

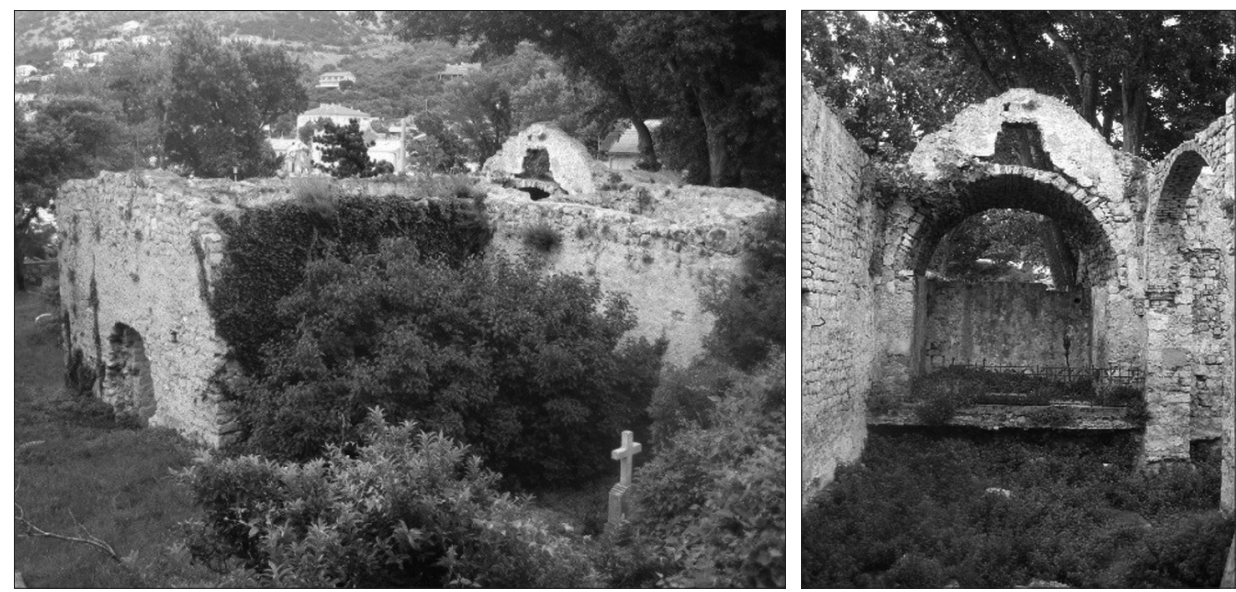

Sl. 12. a) i b) Crkva sv. Filipa i Jakova u Sv. Jurju, 7. lipnja 2008. (foto: Darko Nekić)

Jurja, ali nije morala biti posvećena sv. Jurju. Samostan sv. Jurja ne spominje se godine 1472. u povlastici kojom kralj Matijaš Korvin potvrđuje stara prava senjskih građana: "Građani i njihovi kmetovi, kao i kmetovi crkava sv. Jurja, sv. Križa i sv. Dujma oslobođeni su od plaćanja svake daće." ${ }^{40}$ Dok se spominju crkve, o samostanu nema više spomena.

Opatija je vjerojatno od početka do kraja imala sjedište u Kaštelini, ali je imala crkvu i posjed u Abatovu; često je ondje stanovao i opat. Kaštelina i Abatovo bili su jedno kao Otočac i Baška. Nakon 1338. godine izgleda da su monasi iz Abatova otišli u Kaštelinu, a Abatovo ostalo samo imanje s crkvom. Bernard je - ako je prije stanovao u Abatovu - poslan u Kaštelinu (Sv. Juraj). Da je ondje bilo središte, vidi se i po dodatku Lisački (de Lisac). Crkva u Abatovu pripadala je i dalje opatiji sv. Jurja, ali nije morala biti posvećena istom svecu. Mogla je biti posvećena sv. Dujmu. ${ }^{41}$

Zorislav Horvat sklon je mišljenju da je crkva sv. Filipa i Jakova u Sv. Jurju građena u maniri cistercitskih graditelja 13. stoljeća, što bi značilo

40 "Cives, nec non jobagiones tam ipsorum, tam etiam ecclesiarum sancti Georgii, sanctae Crucis et sancti Duymi exempti et liberati sunt a solution cuiuslibet tributi de quibuscumque rebus et bonis suis mercemonialibus" (M. MAGDIĆ, 1899a., 142; usp. M. MAGDIĆ, 1877, 90). Ovdje se prvi put javlja crkva sv. Dujma. To bi mogla biti crkva koju je opatija sv. Jurja imala u Abatovu. Ta crkva ima svoje kmetove, što upućuje na benediktinsku nadarbinu. O tome će biti više riječi u prilogu o crkvi (opatiji) sv. Dujma.

${ }^{41}$ A. BADURINA - T. GALOVIĆ, 2014, 426-427. 
da je cictercitska opatija u Topuskom ondje sagradila crkvu i potrebne kuće u smislu njihove molbe koju su 1240. godine uputili templarima, tadanjim gospodarima Senja. ${ }^{42}$ Cistercita na tom mjestu nema sredinom 14. stoljeća pa je tako opatija sv. Jurja Lisačkog dobila ondje dodatne prostore. ${ }^{43}$

Ovaj "scenarij" o odlasku redovnika iz Abatova u središnji samostan opatije sv. Jurja pretpostavlja se kao vjerojatan, ali je još nemamo za to takvih dokaza da bismo pitanje smatrali zaključenim. Do velikih promjena unutar opatije svakako je došlo. To se vidi i po novom nazivu. Već je u to vrijeme mjesto gdje je bilo središte opatije nosilo ime Sv. Juraj (prvi poznati spomen je 1318. godine) pa nije bilo prikladno da se opatija zove Sv. Juraj u Sv. Jurju pa je i to, predmnijevam, bio bar jedan od razloga da se opatiji doda ono "Lisački". ${ }^{44}$ Riječ je, dakako, o istoj opatiji samo je u novim okolnostima dobila spomenuti dodatak.

Time je riješena još jedna dilema: nisu to dvije opatije, nego jedna ista. Ipak su ta dva središta djelovala dosta samostalno pa se - i zbog neusklađene terminologije - katkada javljaju pod različitim imenima, odnosno kao dvije opatije. No, iz dokumenata se vidi da je riječ ojednoj opatiji i o jednom opatijskom imanju. Ona je ostala uvijek cjelovita. Tek kada je opatija ostala bez imovine, nije bilo nikakvih posljedica ako dobijemo dvije različite naslovne opatije: sv. Jurja kraj Senja i Lisačkog; pa i onu treću: sv. Dujma. U Rimskoj kuriji taksirana je jednako u vrijeme Ivana XXII. (1316. - 1332.), kao i Sv. Juraj Lisački 50-ih godina istoga stoljeća. ${ }^{45}$

${ }^{42} \mathrm{O}$ tome detaljnije u dijelu o templarima.

${ }^{43}$ Z. HORVAT, 2001, 29. To, dakako, otvara novo pitanje je li ova crkva izvorno benediktinska ili je to današnja župna crkva sv. Jurja.

${ }^{44} \mathrm{O}$ benediktincima na području Senjske i Modruške ili Krbavske biskupije imamo malo sigurnih povijesnih izvora pa su pisci nadoknađivali tu neimaštinu maštom i čudnim kombinacijama. Tako je u shematizmima 19. i 20. stoljeća vođeno da su dvije opatije sv. Jurja: sv. Jurja kod Senja (S. Georgii penes Segniam) i sv. Jurja Lisačkog (S. Georgii de Lisac). Ova druga bi po tom mišljenju bila u Modruškoj biskupiji (usp. Schematismus Cleri ... 1915, 43-44). Neki misle da je Sv. Juraj Lisački (de Lisac) u Modruškoj biskupiji i to nedaleko Slunja prema Karlovcu na brdu koje se zove Lisac. Nisu primijetili da je taj Lisac u srednjem vijeku bio u Zagrebačkoj biskupiji. Mnoge je zaveo i Sladović (M. SLADOVIĆ, 1856, 246). Međutim, sve relevantno o benediktincima na području Senjske i Modruške ili Krbavske biskupije sakupio je Ivan Ostojić (I. OSTOJIĆ, 1964).

${ }^{45} \mathrm{U}$ vrijeme spomenutog pape Ivana XXII. bio je među ostalim samostanima taksiran sa 33 forinta "pro comuni servitio" (CD VII, 443). Jednako je tako platio 1351. godine Nikola "abbas monasterii s. Georgii de Lissa" (CA, I, br. 174; II, br. 1248). 


\section{Komenda}

Benediktinski red razvio se u vrijeme feudalizma i u vrijeme svoga najvećeg rasta nosio je biljege toga društvenog uređenja. Svaka opatija imala je nadarbinu (zemlju, šume, vode, i sl.) na kojoj je zajednica radila i od čega se uzdržavala. Nadarbina je donosila određene prihode. U vrijeme kada su samostani propadali nadarbina je mogla poslužiti krajnjem vlasniku da je dade drugome. Tako se događalo da je nadarbina sačuvala svoju cjelinu, a da više nema nijednoga redovnika, ili ih ima premalo da bi opatija funkcionirala kao redovnička zajednica. Novi korisnik nadarbine zvao se također opat, ali komendatarni jer je njemu povjerena (commendata) nadarbina opatije. On je redovito klerik, ali bilo je slučajeva da bude i laik. Nadarbine su služile papama i kraljevima da nagrađuju i plaćaju zaslužne dostojanstvenike. Dakako da je taj sustav još više pospješio propadanje benediktinskog reda. Još krajem 14. stoljeća došlo je do velikog pada broja benediktinskih samostana u svijetu, a to se osjeća i na hrvatskom prostoru. Jasno je da nadarbina nije mogla donositi prihode ako na njoj nije bilo radnika. I za vrijeme dok je opatija imala dovoljan broj redovnika, imala je još više radnika laika koji su obavljali razne poslove. Radnici su se zvali kmetovi ili koloni i oni su komendatoru radili na nadarbini i donosili urod. Spomenuli smo već da je kralj Matijaš Korvin 1472. godine oslobodio kmetove, odnosno, kolone crkava sv. Križa, sv. Jurja ${ }^{46}$ i sv. Dujma od svake daće. Nadarbine bivših benediktinskih opatija i dalje postoje, ali na njima rade kmetovi u organizaciji komendatarnog opata.

Ne možemo točno utvrditi kada je nestala benediktinska zajednica u opatiji sv. Jurja. Svakako je to bilo najkasnije 1447. godine kada je opata Josipa, koji je bio benediktinac, naslijedio opat Bartolomej, koji je bio dominikanac. Moglo je tada u samostanu biti još nekoliko benediktinaca, ali oni nisu bili u stanju upravljati opatijom i njezinim imanjem. Redovito su se komendatarni opati brinuli za crkvu i nju su opsluživali radi pastoralnih potreba jer je čest slučaj da je oko opatije nastalo naselje o kojemu je pastoralnu skrb vodio opat. Ako to nije mogao vršiti komendatarni opat, trebao je naći kapelana. Dana 2. lipnja 1454. godine spominje se svećenik Ivan iz Senja kao kapelan Sv. Jurja Lisačkog. Opatija je imala i dalje svoje kmetove, ali su oni radili na državnom (kraljevom) dobru. Nakon što je kralj Matijaš 1472. godine oslobodio kmetove Sv. Jurja, Sv. Križa i Sv. Dujma svake daće ${ }^{47}$, opatije.

${ }^{46}$ Kmetovi opatije sv. Jurja koji su radili na posjedu u Abatovu i na drugim posjedima iste ${ }^{47}$ M. MAGDIĆ, 1877, 90. 
opatija je svome vlasniku i dalje donosila prihode. Tako Matijašev nasljednik kralj Vladislav daje 1498. godine Senjanima 100 libara i 16 florena od svojih dobara u Sv. Jurju i Kozjanu..$^{48}$

Da je mjesto Sv. Juraj smatrano središtem opatije, znamo i po tome što se godine 1459. obavezao neki Morsa, stanovnik na Velebitu, da će dovesti grede za gradnju franjevačke crkve u Kamporu na Rabu na more opatije sv. Jurja senjskoga. ${ }^{49}$ Očito je riječ o mjestu Sv. Juraj. Dakako da se i nadarbina postupno rastakala. Njezine posljednje obrise vidimo 1515. godine u sporu između otočkog biskupa Vinka de Andreisa, zadnjeg poznatog komendatarnog opata Sv. Jurja, i senjske općine.

Biskup Vinko Andreis imenovan je još 1504. komendatarnim opatom Sv. Jurja Lisačkog blizu Senja (abbatia sancti Georgii de Lisacz prope Segniam), ali nije mogao preuzeti imanje te opatije jer je ono već dugo bilo u vlasništvu senjske općine (Kaštela i grada Senja). Biskup se potužio kralju Ladislavu i on izdaje 15. kolovoza 1515. godine darovnicu kojom opatijsko područje oduzima Senju i daje ga biskupu. U darovnici se navodi šest selišta (sessiones). Dva su u Liscu (in villa seu possessione Lisacs), dva su vlaška (stočarska) u Dolcu i dva su na Brdu sv. Jurja, a zovu se Nalaza i Čužova (Chuxova). ${ }^{50}$ Kralj je naložio Senjskom kaptolu da uvede Andreisa u posjed opatije sv. Jurja. Prethodno je trebalo izvidjeti ima li tko razložni prigovor tom darovanju. Pred opatskom crkvom sv. Jurja u Liscu trebao je Andreis 7. listopada iste godine biti službeno uveden u posjed pred predstavnikom Kaptola (kanonik Bartol Dušica) i pred kraljevim čovjekom (Matej Luković iz Gacke). Međutim, na tom sastanku je zastupnik senjske općine Kristofor Galzigna, zakoniti prokurator općine grada Senja, javno protestirao pred zastupnikom otočkog biskupa Andreisa i svim nazočnima protiv zaposjednuća ovih šest zaselaka od strane otočkog biskupa jer ona od starine pripadaju

${ }^{48}$ M. MAGDIĆ, 1899a, 145. U to vrijeme Frankopani su nastojali oteti kralju Senj pa je Anž Frankopan upravo u Sv. Jurju izgradio utvrdu kao uporište za napad na Senj. Nepoznati pisac javlja iz Senja da Anž "ha fatto uno bastione alla marina di Sto Zorzi" (F. ŠIŠIĆ, 1937, 22).

49 "ad mare abbatiae sancti Georgii de Segnia" (Državni arhiv u Zadru, Sudski arhiv u Rabu, Acta de Stantiis, 326-327).

${ }^{50}$ Brdo Svetog Jurja je vjerojatno današnje brdo Nehaj. Nalaza bi mogla biti uvala između Nehaja i Abatova. Stara riječ "laz" nestala je iz uporabe; sačuvala se s prefiksima: $u(l a z), z a(l a z)$, pro(laz). Toj vrsti riječi pripadao i je i naziv $\mathrm{Na}(\mathrm{laz})$ a. Na starim kartama nalazimo na prostoru današnjeg Rončević Dolca naselje Dolac, a još u 19. stoljeću ono se zvalo Kaluđeri. Vjerojatno je ovdje riječ o tom Dolcu. Prošao sam tim putem u rujnu 2020. godine. Dolci su samo prije sela Rončević Dolac. Mještani kažu da je ispod sela bilo više dolaca, ali je sada sve zaraslo pa to nije više tako uočljivo. 
općini grada Senja. ${ }^{51}$ To je zapisnički provedeno pred senjskim kapetanom Jeronimom Petelineom. Daljnji razvoj parnice nije nam poznat, ali smatram da je on nakon 1522. godine, kada su Turci počeli paliti i pljačkati oko Senja, postao bespredmetan.

Čini se da su na dan sv. Jurja godine 1522. Turci martolozi iznenada navalili i zarobili silu svijeta pred crkvom sv. Jurja. To tzv. "svetojursko roblje" oslobodio je ban Karlović. Kao i ostali samostanski objekti izvan zidina Senja, tako je opatijska crkva u Abatovu napuštena, a 1540. godine porušena je kao i druge građevine izvan zidina da ne bi poslužila kao zaklon Turcima kod sljedećeg napada. Nakon što je opatija sv. Jurja prestala postojati kao redovnička zajednica, sada je prestala postojati i kao posjed (nadarbina) i ostao je samo počasni naslov uglednim crkvenim dostojanstvenicima, uglavnom senjskim kanonicima.

\section{Naslov}

Dobra napuštenog samostana sv. Jurja preuzela je država (senjska općina), dok se ime opatije sv. Jurja sačuvalo do najnovijih vremena u časti naslovnog opata koja se podjeljuje crkvenim dostojanstvenicima (kanonicima) u Senjskoj biskupiji (abbatia titularis s. Georgii M/ilitis/ et M/artyris/ penes Segniam).

Iz vremena nakon što je nestalo zajednice i nadarbine spominju se kloštar i crkva 1639. godine u jednom obalnom "peljaru" od Senja do Dračevca. Ondje je luka u kojoj mogu pristati mali i veliki brodovi, ondje je crkva i kloštar. ${ }^{52}$ Car Leopold I. 1685. godine spominje opatiju sv. Jurja i kaže da se nalazi pod senjskim gorjem. ${ }^{53}$ Car Leopold I. imenovao je oko godine 1680. senjsko-

${ }^{51}$ Što se tiče crkve sv. Jurja, gradskog zaštitnika, može se reći da je ona od davnine (diu et $a b$ antiquo) pripadala senjskoj općini. Općina je pravno imala patronat nad opatijom Sv. Križa jer se to izričito spominje u Statutu iz 1388. u par. 167 (M. MAGDIĆ, 1877, 79; L. MARGETIĆ, 1985-1987, 78, 94), ali je i pored toga Sveta Stolica imenovala komendatarne opate. Opatija sv. Jurja ne spominje se u Statutu iz 1388. godine, ali se spominju kmetovi Sv. Jurja u povelji kralja Matijaša 1472. godine u kojoj kralj potvrđuje stara prava grada Senja i dodaje neka nova, a upravo u tim novima spominje se crkva opatije sv. Jurja (M. MAGDIĆ, 1877, 90). Budući da kralj u dokumentu kojim potvrđuje "senjske pravice" oslobađa kmetove crkve sv. Jurja svake daće, može se time opravdavati tvrdnja prokuratora senjske općine 1515. da je nadarbina opatije sv. Jurja od davnine (diu et ab antiquo) u vlasništvu senjske općine.

52 "Suetti Iuray dobar porat za brode male i velike i za ribu loviti u kom je portu dobre slatke vode ke nigdar ne manka.... I oni je kloštar i criqua i nekoliko chuch zidanih pustich i ta je porat daleko od Segnia migl pet lattinskih" (R. LOPAŠIĆ, SHK, II, 1885, 211; LJ. KRMPOTIĆ, 1997, 322. 42).

53"abbatia sancti Georgii in submontanis Segniae" (M. MAGDIĆ, 1899a, 150). 
modruškim biskupom Franju baruna Čikulina, koga Sv. Stolica nije potvrdila. Čikulini se vladao da je sve regularno i izdavao je razne odredbe. Tako je spojio župu Sv. Juraj i opatiju istoga naslova u jedno i imenovao Stjepana Pribinovića opatom i župnikom župe Sv. Juraj. Senjski kaptol je protiv toga imenovanja godine 1681. prosvjedovao kod ugarskog ostrogonskog primasa, dokazujući da je župa Sv. Juraj od pamtivijeka ( $a$ b immemorabili) inkorporirana Senjskom kaptolu, a pravo prezentacije izbora opata sv. Jurja također od pamtivijeka pripada senjskom municipiju. Kaptol je za to pitanje zainteresirao i papinskog nuncija u Beču. Ostrogonski primas odgovara da mu o imenovanju Stjepana Pribinovića nije ništa poznato, a papinski nuncij 1682. godine upozorava Senjski kaptol neka se posluži svojim pravom glede imenovanja župnika u Sv. Jurju. ${ }^{54}$

Još je jednom izbilo na površinu pitanje senjske opatije sv. Jurja. Godine 1686. podijelio je car Leopold I. naslovnu opatiju sv. Jurja Tomi Chamsi, župniku u Lovranu, koji si je prisvojio pravo na čitavo Podgorje (potpisivao se kao "opat sv. Giurgia i svega podghoria" pa je čak 9. svibnja 1688. imenovao nekog Šimuna Lovrinčića župnikom u Karlobagu. U posjed ove opatije uveli su ga suci grada Senja. Kaptol je senjski protestirao na to kod bečkog nuncija i to u pogledu dohodaka iz sv. Jurja koji su već 50 godina do tada pripadali Senjskom kaptolu. Bečki nuncij se obratio Karlovačkom generalu moleći ga da stane na put presizanju i uplitanju Chamse u tuđa prava. Za opatsku crkvu sv. Jurja veli se u ispravi Senjskog kaptola od 10. svibnja 1688. godine da se od nje mogu vidjeti samo ruševine..$^{55}$

U vrijeme biskupa Benzonija (1730. - 1745.) imao je nad senjskom opatijom sv. Jurja patronatsko pravo ugarski kralj i on se tim pravom služio te je predlagao opate senjskom biskupu koji bi im onda podijelio blagoslov. Tako je 1742. godine kraljica Marija Terezija izabrala za mitronosnog opata sv. Jurja kod Senja Jurja Wolfganga Čolića, arhiđakona i generalnog vikara, kasnijeg nasljednika biskupa Benzonija. Nastade u ovome izmjena jer od tada za ovu naslovnu opatiju ima "jus praesentandi" senjski biskup. Zadnji naslovni opat sv. Jurja kod Senja bio je kanonik u Bribiru Franjo Lorbek (+1936.).

Neusklađena terminologija navela je neke da misle o različitim opatijama: jedna kraj Senja, a druga izvan Senjske biskupije. Shematizmi Senjsko-modruške ili Krbavske biskupije iz 20. stoljeća naznačuju u isto vrijeme dva mitronosna opata sv. Jurja i razlikuju dvije opatije sv. Jurja: jednu kod Senja (penes ili prope Segniam), a drugu de Lisac u Modruško-krbavskoj biskupiji. Tako bi opatija Sv.

\footnotetext{
${ }^{54}$ M. SLADOVIĆ, 1856, 178.

${ }^{55}$ J. BURIĆ, 2002, 161.
} 
Jurja bila jedno, a opatija Sv. Jurja Lisačkog drugo. Ona de Lisac mogla bi biti i na brdu Lisac kraj Slunja. ${ }^{56}$ No, jasno je da je područje slunjskog Lisca bilo u srednjem vijeku u Zagrebačkoj biskupiji pa tu mogućnost treba odmah isključiti jer je uz naziv opatije redovito dodatak "Senjske biskupije". Pored toga, jasno proizlazi iz samih spisa da su ista imena opata jednom spomenuta uz naziv Sv. Jurja kod Senja, a drugi put uz naziv Sv. Jurja "de Lisac". U Modruško-krbavskoj biskupiji bilo je još nekoliko Lisaca pa neki traže lisačku opatiju između Dabra i Jesenica. To nikako ne stoji, a još manje bi to mogao biti sv. Juraj u selu Liscu kod Jelšana povrh Rijeke. ${ }^{57}$ Prema tome, nema sumnje da se radi o jednoj, a ne o dvije opatije.

\section{Opati}

a) stvarni:

Ivan 1245.

Bernard 1333.

Mihovil 1333. - 1338.

Bernard (1338. - 1352.)

Nikola (1349. - 1352.) 1352. - 1354.

Kuzma 1354. - 1360.

Nikola 1426.

Josip 1426. - 1445.

b) komendatarni:

Bartolomej 1445. - 1457.

Juraj 1463.

Stjepan Belohant 1463. -

Blaž de Vimica 1469. -

Donat, krčki biskup, 1491. -

Vinko de Andreis, otočki biskup, 1504. - 1515.

Jakov Blažiolović, senjski biskup, 1504.

c) naslovni:

Stipan Pribinović 1682.

Toma Hanza de Dobrontal, vranski župnik, 1685.

Petar Antun Gaus, riječki arhiđakon pa pićanski biskup, 1688. -1693.

Nikola Pohmajević, senjski biskup, 1718. - 1730.

Juraj Vuk Čolić de Lewensperg, senjski biskup, 1746. - 1764.

${ }^{56} \mathrm{O}$ tome i o drugim relevantnim podacima vidi: I. OSTOJIĆ, II, 206-208.

${ }^{57}$ M. SLADOVIĆ, 1856, 246. 
Đuro Primes, šopronski župnik, prije 1777.

Đuro Dolović, čazmanski kanonik, 1777. - 1793.

Franjo Ksaver Lučić, zagrebački kanonik, 1818. - 1835.

Toma Dujmović, župnik Otočca, 1836.

Antun Vukasović, zagrebački kanonik, 1841.- 1852.

Franjo Crnogorčević, senjski kanonik, 1852.- 1863.

Stjepan Vuković, zagrebački kanonik, 1869.- 1871.

Augustin Kajetan Bedini, senjski kanonik, 1882.-1889.

Franjo Canjuga, župnik Gospića, 1897.- 1910.

Franjo Lorbek, modruški kanonik, 1913. -1936.

Sv. Juraj Lisački (de Lisac)

a) naslovni

Franjo Lužić, zagrebački kanonik, 1827.

Antun Vukasović, senjski i zagrebački kanonik, 1841. - 1855.

Stjepan Sarkotić, župnik u Perušiću, 1861.- 1880.

Pavao Miler, župnik u Mitrovici, 1882. - 1902.

Mate Cvetko, modruški prepozit, 1913. - 1939

\section{Opatija Sv. Križa u Senjskoj Dragi}

Jedini sigurni podatci o ovoj opatiji jesu pismo pape Benedikta XII. iz 1338. godine i Statut senjskog kaptola dvije godine poslije toga. Počeci opatije zacijelo su mnogo stariji, ali tu prošlost ne možemo provjeriti. Od kraja 14. stoljeća ona je vezana uz Senjski kaptol, a arhiđakon je često bio i opat Sv. Križa, što je bio također slučaj sa senjskim tiskarom Silvestrom Bedričićem koji je ondje i boravio. Tako nas taj podatak vodi prema zaključku da je u Senjskoj Dragi bila glagoljska tiskara što će kasnije biti zabilježeno. ${ }^{58}$

Nakon smrti senjskog biskupa Jurja, papa Ivan XXII., u skladu s prethodnim dogovorom s istim Jurjem, imenovao je 3. siječnja 1333. godine Jurjevim nasljednikom augustinca Ivana iz Pise. Taj je krenuo prema Senju, ali u Rabu je doznao da ga u Senju ne žele primiti jer je Senjski kaptol, u skladu s prijašnjom praksom, izabrao za Jurjeva nasljednika Bernarda, opata benediktinske opatije sv. Jurja kraj Senja, a splitski nadbiskup je istoga Bernarda posvetio za biskupa. Tada je nasljednik Ivana XXII., papa Benedikt XII., 1338. godine poslao u Senj pismo kojim izopćava one koji podržavaju

${ }^{58}$ V. KRALJIĆ, 1975, 77-80. 


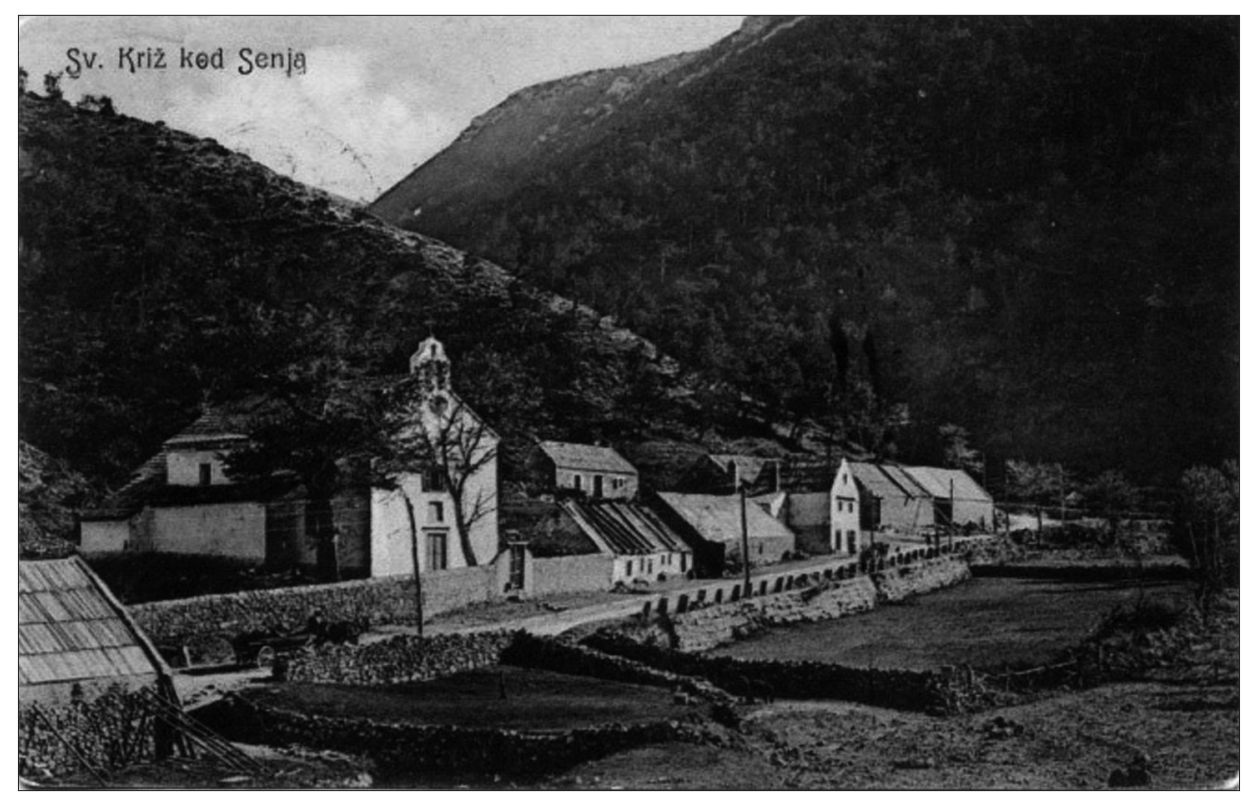

Sl. 13. Senjska Draga - Sveti Križ početkom 20. st. (izvor: Gradski muzej Senj)

Bernarda. Među onima koji su podržavali Bernarda bio je i Franjo, opat Sv. Križa u Senjskoj Dragi. Papin kandidat Ivan uskoro je preuzeo upravu Senjske biskupije, a kaptol je donio Statut u kojemu se više ne spominje njegovo pravo da izabire biskupa. U donesenom Statutu (1340. godine) govori se pak o odnosu kaptola prema opatiji Sv. Križa. Kada kaptol svečano dolazi na crkveno slavlje u opatijsku crkvu u Senjskoj Dragi, navodi se koje su obveze kaptola prema opatiji i opatije prema kaptolu. "Kada kaptol dođe sa križem do mojstira sv. Križa na blagdan Našašća sv. Križa, samostan ima dati kaptolu objed, a opat ima poslati konja po arhiđakona senjske crkve, te na blagdan sv. Ćirila dati kaptolu jedan star pšenice i jedan sir." Uz to, statuti Senjskog kaptola određuju da ovaj samostan ima davati Senjskom kaptolu svake godine šest libara, a u slučaju bilo kakve kontribucije (nametanja kakvih podavanja "niki daci") Senjskoj biskupiji jednu četvrtinu od ukupnih tereta ima platiti opatija Sv. Križa zajedno s opatijom sv. Jurja kod Senja. ${ }^{59}$

U potrazi za sjedištem te opatije (i poslije društvene organizacije) možemo tražiti na trima putovima potoka ili bujica koji se s vratničkih visina

${ }^{59} \mathrm{O}$ tim događajima opširno sam pisao u svom članku Crkvene prilike u Senju u 14. stoljeću i Statut Senjskog kaptola, 1988, 15-27. 


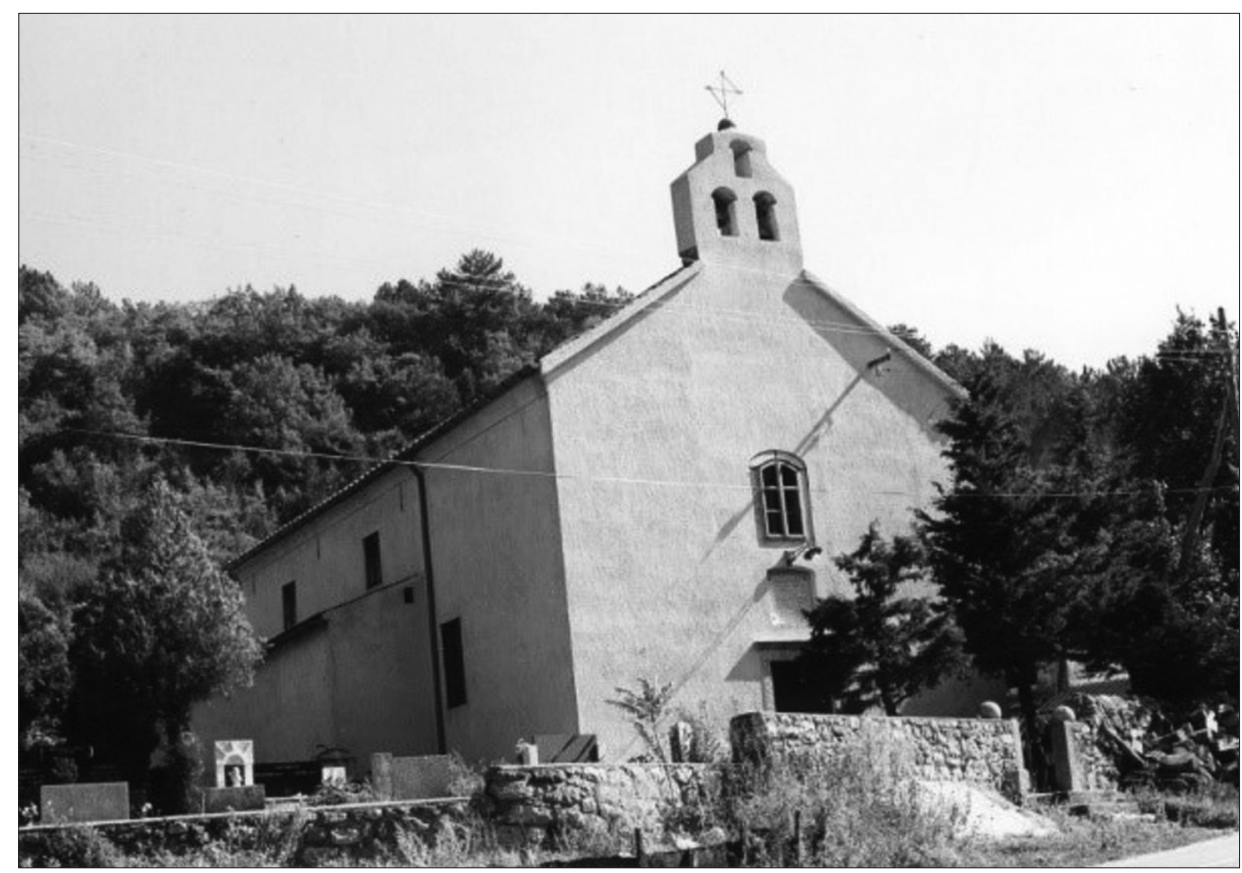

S1. 14. Crkva Sv. Križa u Senjskoj Dragi (izvor: Gradski muzej Senj)

spuštaju prema Senju. Uz te tri jaruge-potoke-bujice nastala je opatija i poslije gospodarska organizacija. Jedna mogućnost je da je to središte bilo na prostoru današnjih Gornjih Lopaca gdje je još krajem 18. stoljeća bilo naselje zvano Kaluđeri. Onuda prolazi jedna od triju bujica-potoka. Druga je mogućnost da je središte bilo na mjestu današnje crkve Sv. Križa gdje se ta bujica-potok spaja s Kriškim potokom.

Treća mogućnost jest da je središte bilo na izvoru Kriškog potoka jer se ondje i danas vide podzidi koji svjedoče da je tu nekada bilo veliko gospodarstvo. Iako su tragovi većeg gospodarstva tu najprepoznatljiviji, oni mogu potjecati iz vremena kada ondje nije više postojala redovnička zajednica. Naziv Kaluđeri nalazimo i u dolcu niže današnjeg Rončević Dolca, ali je vjerojatnije da je ondje bio neki gospodarski pogon nego središte opatije. Veću vjerojatnost za središnju poziciju ima lokacija tzv. Krajačevi mlinovi gdje se u Kriški potok sliva središnji potok-bujica, ali i ta varijanta nije sigurna. Moguće je i to da se središte stvarne opatije ne poklapa sa središtem opatije komende (gospodarstvene organizacije). No, i u vrijeme kada je opatija tretirana kao 

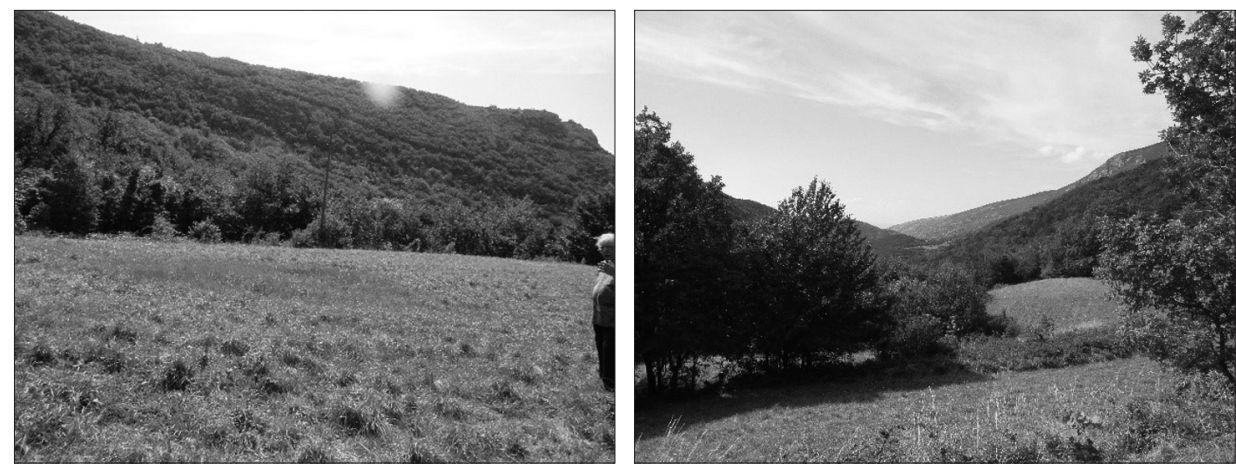

Sl. 15. a) i b) M. Bogović u potrazi za opatijom Sv. Križa u Senjskoj Dragi, 15. kolovoza 2020. (foto: B. Ljubović)
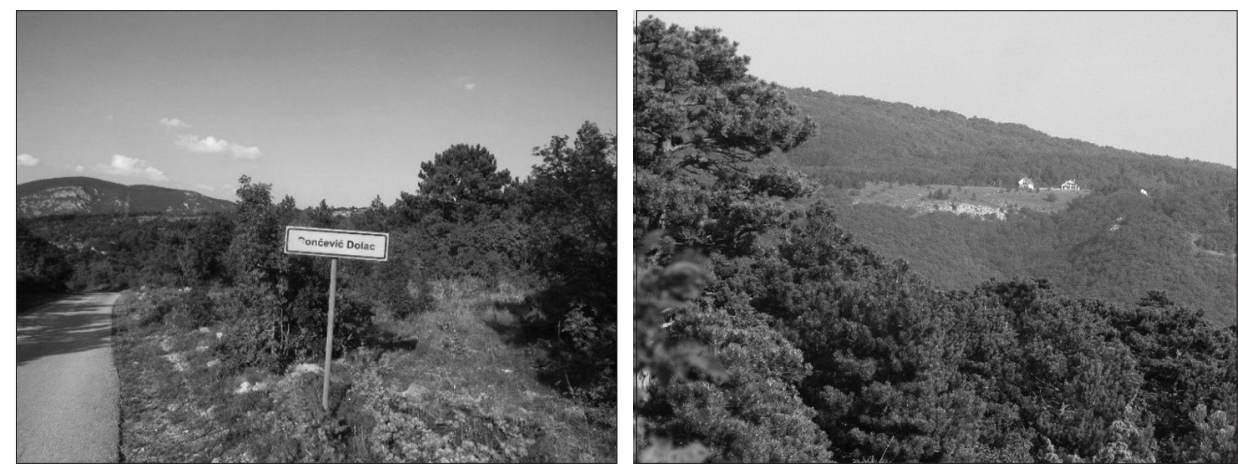

Sl. 16. a) i b) Obilazak lokaliteta, Rončević Dolac, 16. rujna 2020. (foto: B. Ljubović)

komenda, ona je sačuvala svoj crkveni karakter jer je imala svoju crkvu i bila je uključena u crkveni ekonomski sustav. ${ }^{60}$

Svakakoizvori nedvojbeno govore o postojanju te opatije kao benediktinske redovničke zajednice, a ne samo kao komendatarne opatije, tj. posjeda koji se za nagradu ili plaću daje neki crkvenim dostojanstvenicima.

Crkvu Sv. Križa spominje i Statut grada Senja 1388. godine. Paragraf 167. glasi: "Plemići senjski imaju pravo patronata u crkvi sv. Križa imenovati župnika ili opata te crkve"61, a što ponavlja i Statut iz godine $1640 .{ }^{62} \mathrm{Ne}$ govori se ni

${ }^{60} \mathrm{Ni}$ Ante Glavičić, iako je upućen u dotadanja mišljenja i u predaju u narodu, nije uspio riješiti zagonetku gdje je bilo središte, s crkvom i samostanom, benediktinske opatije Sv. Križa (v. A. GLAVIČIĆ, 2003, 28-30).

${ }^{61}$ L. MARGETIĆ, 1985-1987, 65, 78.

62 "... Item, quod nobiles civitatis Segnie habent jus patronatus in ecclesia Sanctae Crucis de Valle Segnie in elligendo plebanum seu abbatem illius ecclesiae" (M. MAGDIĆ, 1900a, 80, 93). 
1388. godine o redovničkoj zajednici, nego samo o župi čiji župnik nosi naslov opata po opatiji koja je tu postojala..$^{63} \mathrm{Da}$ opatija u to vrijeme više ne postoji kao redovnička zajednica, potvrđuje i suvremeni izvor iz 1389. godine. Te godine je održan metropolijski sabor u Splitu na kojem su trebali sudjelovati svi biskupi i opati iz Splitske metropolije. Budući da iz Senjske biskupije nisu bili ni biskup ni opati sv. Jurja kraj Senja ni opet sv. Nikole u Otočcu, svu trojicu metropolit je novčano kaznio. ${ }^{64}$ Nema spomena opata Sv. Križa u Senjskoj Dragi. Istina, mogao je samo taj opat ići u Split, ali to je mala vjerojatnost.

Taj samostan kao nadarbina spominje se 4. svibnja 1452. godine. Toga dana Sveta Stolica upućuje dopis senjskom biskupu da Ivana iz Dubrovnika (Johannes de Ragusa) imenuje na ispražnjeno mjesto opata benediktinske opatije Sv. Križa u Senjskoj Dragi. Ivan je franjevac i kapelan Stjepana Frankopana koji se za njega zauzeo kod Apostolske komore u Rimu posebno zato što ima staru i teško bolesnu majku. Opatija je do tada bila taksirana s 35 florena; već dugo je ispražnjena, napose nakon što je na njoj rezignirao opat Blaž. Kao razlog te molbe navodi knez i siromaštvo koje je zavladalo u zemlji. ${ }^{65}$ Očito je da tada u opatiji nisu benediktinci, a nisu bili već duže jer se preporučuje franjevca za opata. Imanje koje je prije bilo vezano uz opatiju, povezuje se uz crkvu Sv. Križa. Tako kralj Matijaš Korvin potvrđujući 1472. godine stara prava senjskih građana kaže da među ta prava spada i pravo "patronata u crkvi sv. Križa imenovati župnika ili opata te crkve", kako je gore rečeno. Uz to, dodaje kralj i pravo kmetova Sv. Križa, zajedno s onima Sv. Jurja i Sv. Dujma, da ne plaćaju nikakve dace.$^{66}$ Svakako, više se u pogledu opatijske crkve ne pita ništa Frankopane, nego kralj odlučuje kome će se ona povjeriti. Vjerojatno je u tom smislu bilo dogovoreno 1484. godine ročište u Bužanima na kojem su bili predstavnici senjskog biskupa i Senjskog kaptola s jedne strane, a draški opat Ivan s druge strane. Budući da se nije pojavila ključna osoba, modruški biskup Antun, ročište nije održano. ${ }^{67}$ Svakako su senjska

${ }^{63}$ U latinskom originalu župnik se naziva "plebanus" (plovan), tj. župnik za puk (plebs), za razliku od župnika grada (civitatis).

${ }^{64}$ CD XVII, 236-237. Doduše, teoretski bi opat Sv. Križa mogao doći u Split na sinodu iako nitko drugi iz njegove biskupije nije došao, ali je to malo vjerojatno.

${ }^{65}$ ASV, Reg. Supl., vol. 459, f. 52v-53r, regest kod P. LULCSICS, 1938., br. 1264; pismo senjskom biskupu objavljeno je u: Bullarium franciscanoruum, Nova series I (1439. - 1455.), ad Claras Aquas, 1929.

66 "Građani senjski, koli kmetovi senjski, toli crkva sv. Jurja, sv. Križa i sv. Dujma, prosti su od plačanja svake daće" (M. MAGDIĆ, 1877, 90). Znakovito je da se ovdje spominju i druge dvije crkve: sv. Dujma i sv. Jurja. Jedna od njih vjerojatno je ona u Sv. Jurju, a druga u Abatovu.

${ }^{67}$ Đ. ŠURMIN, 1898, br. 190, 300-302. 
općina i Senjska biskupija ubrzo uspostavili svoje pravo na Senjsku Dragu, što se dade iščitati i iz dopisa pape Aleksandra VI. koji 19. studenoga 1499. godine naređuje senjskom biskupu (ne spominje ime!) i arhiđakonu Blažu (Balasu) iz Baške da predaju u cijelosti opatiju sv. Križa Jakovu Blažioloviću. Naime, opat Ivan odrekao se opatije i predao je biskupu Mihovilu Božičeviću. Ovaj ju je predao Jakovu Blažioloviću, ali je za sebe zadržao materijalnu i duhovnu upravu. ${ }^{68}$ Od tada su senjski arhiđakoni i prepošti često dobivali na upravu tu opatijsku crkvu. Nju je dobio na upravu 1500. godine i senjski arhiđakon Silvestar Bedričić i upravljao njome do smrti 1512. godine.

U to vrijeme pada i druga faza djelovanja Senjske glagoljske tiskare kojoj je čelna osoba bio upravo Bedričić. Arhivist Biskupskog arhiva u Senju, mons. Vladimir Kraljić, pronašao je podatak o postojanju glagoljske tiskare u Senjskoj Dragi. Naime, u vrijeme vizitacije Senjskog kaptola od strane biskupa Čolića 1751. godine, biskupu su senjski svećenici trebali odgovoriti na više pitanja: o svakoj crkvi, o kaptolu, o pojedinim svećenicima i o važnim događajima iz prošlosti. Na pitanje o arhiđakonu Ivan Krstitelj Dragančić, arhiprezbiter, odgovorio je: "Arhiđakon pak, kako se sjećam da sam čitao u nekoj glagoljskoj knjizi grofa de Conti, stanovao je u Dragi ili Valle i ondje je bila glagoljska tiskara". ${ }^{69}$ Postavilo se pitanje je li to otkrivena nova tiskara ili je ta tiskara sastavni dio Senjske glagoljske tiskare. Nitko nije analizirao povijesni kontekst pa je pitanje ostalo neodgovoreno do danas. Prvi dio rada tiskare vezan je uz Blaža Baromića i uglavnom je neka suglasnost da je njegova tiskara bila u blizini katedrale, odnosno u gradskom središtu. Druga faza vezana je uz arhiđakona Silvestra Bedričića pa se već po naslovu arhiđakona moglo pomisliti da bi se zapis mogao odnositi na drugu fazu rada senjske tiskare. $\mathrm{U}$ kolofonu Naručnika plebanuševa i Transita sv. Jeronima izričito se spominje arhiđakon Silvestar Bedričić. Kada se zna da je opatijska crkva Sv. Križa od kraja 15. stoljeća pa dalje davana često senjskom arhiđakonu, onda se nekako sve poklapa da je to i u ovom slučaju bilo. Kada je ta opatijska crkva došla u nadležnost Senjskog kaptola, dobio je kaptol i velike prihode. Prije razorenja

${ }^{68}$ ASV, Reg. Lat., vol. 1058, 225v-228r. Ivan je 3. ožujka 1455. godine platio Apostolskoj komori taksu od 12 florena (CA, II, br. 704, str. 392, br. 331, str. 234), a kod imenovanja Jakova Blažiolovića 1499. godine navedeno je da se od opatije Sv. Križa ne plaća pristojba (CA, II, br. 331, str. 234).

69 "Archidiaconus autem ut memini me legisse in aliquo libro Glagolitico Comitis de Conti, habitabat in Draga sive in Valle, ibique Typographia Glagolitica fuit" (Biskupski arhiv Senj - dalje: BAS, F I, 49 B; V. KRALJIĆ, 1975, 77-80). Cijeli razgovor Dragančića i Biskupa objavio je Šime Demo (Š. DEMO, 2007, 137-141). Kraljić stalno piše: Draganić, a Demo: Dragančić. 
opatijski beneficij donosio je 1000 škuda godišnje, kako piše opat Vuk Homolić sredinom 18. stoljeća. ${ }^{70}$ Zato nam djeluje uvjerljiva Dragančićeva izjava da je arhiđakon stanovao u Dragi i da je ondje bila glagoljska tiskara. Ipak, mislim da izgleda sve sigurnije da je riječ o istoj tiskari kada se govori o drugoj fazi Senjske glagoljske tiskare i kada se govori o tiskari u Senjskoj Dragi. Povezuje ih ista osoba senjskog arhiđakona (Silvestra Bedričića). Poslije Bedričića teško bi se koji senjski arhiđakon usudio stanovati u Senjskoj Dragi, a još manje ondje osnivati tiskaru, jer su nadolazili opasni dani za sve izvan senjskih zidina, a ti opasni dani vjerojatno su bili razlogom da se Senjska glagoljska tiskara već nakon druge godine rada ugasila. Ostaje ipak jedna nedoumica zašto Dragančić ne spominje ni Sv. Križ ni opatiju, nego samo Dragu. Senjska Draga počinje već kod današnjeg groblja pa je tiskara mogla biti mnogo bliže Senju nego što je bila opatijska crkva Sv. Križa. ${ }^{71}$ Ovo je još jedan poticaj da se senjsko glagoljsko tiskarstvo i dalje istražuje.

U vrijeme kada se rušilo sve što je izvan senjskih zidina, zacijelo je srušena i opatijska crkva. Možda je upravo opasnost od turskih provala zaustavila rad Senjske glagoljske tiskare. Koloni su pobjegli sa zemljišta pred Turcima, a drugo su razgrabili privatnici. Ostalo je samo nekoliko komada zemlje uz crkvu. Tek je 1682. godine imenovan Mihovil Desantić za opata tako da se donekle znalo tko treba voditi brigu o opatijskom imanju. Biskup Martin Brajković javlja u svom izvješću 1700. godine da je opatija srušena. ${ }^{72}$

Patron ove opatije bila je i u novom vijeku senjska općina (municipij), koja je novoga opata prezentirala ostrogonskom nadbiskupu da mu dade blagoslov. Primas bi ga potvrdio javnom ispravom i predao bi mu mitru $v i$ brevi apostolici. Ta praksa zabilježena je još u Senjskom statutu 1388. godine. Godine 1749. nastao je nesporazum prigodom imenovanja opata Sv. Križa. Kraljica Marija Terezija bila je tu čast podijelila poznatom povjesničaru i zagrebačkom kanoniku Baltazaru Krčeliću, a senjski je municipij bio predložio za tu čast primicera Senjskog kaptola Vuka Homolića. Krčelić, uvidjevši da se nepropisno postupilo, rezignirao je na časti i dobio naslov neke druge opatije. Od naslovnih opata Sv. Križa spominje se svega šest.

${ }^{70}$ V. KRALJIĆ, 1980, 326. Možda je to bio kotač koji je pokrenuo tiskaru. U molbi Stjepana Frankopana 1452. godine da se opatija dade njegovom kapelanu Ivanu iz Dubrovnika stoji da godišnji prihodi ne prelaze 20 zlatnih dukata godišnje (ASV, Registri Supplicantium, vol. 459, f. $52 \mathrm{v}-53 \mathrm{r}$ ).

${ }^{71}$ P. TIJAN, 1994, 109-116.

72 "In Valle Segniensi cernitur destructa Abbatia S. Crucis" (D. FARLATI, 1769, 155; M. BOGOVIĆ, 2003, 423). 
Farlati veli da je opat Sv. Križa u Senjskoj Dragi imao odvajkada pravo na pontifikalna insignia i da se tim pravom služio. Tako je npr. opat Sv. Križa Juraj Homolić aktivno sudjelovao kao sukonsekrator kod biskupske konsekracije biskupa Nikole Pohmajevića 1718. godine. ${ }^{73}$ Opatija Sv. Križa spominje se i 1726. godine. Ugarska dvorska kancelarija pozvala je te godine senjske plemiće neka joj kroz mjesec dana podastru dokaze o svom pravu da biraju naslovnog opata i župnika Sv. Križa. ${ }^{74}$ To su podaci, a ostalo su nagađanja. Neka od njih mogu biti točna, ali nemamo za njih potvrdu u izvorima. Razna mišljenja o toj opatiji opisao je Ivan Ostojić u svom monumentalnom djelu o benediktincima u Hrvatskoj. ${ }^{75}$

Što se dogodilo s tom opatijom da je ostala još u drugoj polovici 14 . stoljeća bez redovnika, a dalje da je postojala tek kao nadarbina? I tu možemo samo nagađati. Jedno od mišljenja je da je redovnika nestalo zato jer je u to vrijeme dosta benediktinaca otišlo iz senjskog kraja u Prag na poziv kralja Karla IV. i ondje je ustanovljena glagoljaška opatija na lokalitetu Emaus. ${ }^{76}$ Moguće je da su se redovnici preselili u Prag, a njihova prijašnja opatija da je ostala samo nadarbina koja se davala i nebenediktincima.

Položaj nekadašnjega samostana je na cesti prema Vratniku, $5 \mathrm{~km}$ istočno od Senja, na teritoriju današnjeg sela Sv. Križ. Isto ime sačuvano je i u časti mitronosnog opata Sanctae Crucis in Valle Segniensi. Danas gotovo i nema ostataka od toga samostana, a nova župna crkva podignuta je za taj kraj zapadnije uz potok oko 1700. godine.

\section{Opati}

Franjo, 1333. - 1338. To je jedini poznati opat benediktinskog samostana Sv. Križa u Senjskoj Dragi.

a) komendatarni (nema redovnika, ali je ostao njihov posjed):

Blaž (je li on dobio opatiju sv. Jurja Lisačkog?), prije 1452.

Fra Ivan iz Dubrovnika, franjevac, 1452. - 1484.

Mihovil Božičević

Jakov Blažiolović, 1497. - 1499.

Silvestar Bedričić, 1499. - 1512.

${ }^{73}$ M. SLADOVIĆ, 1856, 119.

${ }^{74}$ 1726. Vienae 14. Martii "abbatiam S. Crucis de Valle Segniensi" (M. MAGDIĆ, 1899a, 152).

${ }^{75}$ I. OSTOJIĆ, II, 209-210; III, 239.

${ }^{76}$ M. BOGOVIĆ, 2019, 27-28, 88-93; T. GALOVIĆ, 2016, 145. 
b) naslovni (počasni) opati:

Mihovil Desantić, 1662.

Ivan Weiss (Bajs), 1674.

Juraj Homolić, 1718. - 1733.

Ivan Homolić, 1733. - 1748.

Baltazar Adam Krčelić, zagrebački kanonik, 1749.

Vuk (Wolfgangus) Homolić, senjski kanonik i primicerij, (1749.) 1754. - 1796.

Dane Hreljanović

Filip Vukasović, veliki prepošt i opat, 1807. -

Agrikola Kargačin, modruški prepozit, 1856.

Ignacije Vinski, senjski kanonik, 1862. - 1901.

Ivan Vidas, senjski kanonik, 1913. - 1939.

\section{Opatija sv. Dujma iznad Senja}

Sveti Dujam kao crkva spominje se prvi put u Senju u ispravi kralja Matijaša Korvina kojim on, nakon što je oteo Frankopanima Senj, potvrđuje stare senjske pravice. Uz to, dodaje još četiri nove, a prva od njih je oslobađanje od svake daće kmetova crkava sv. Križa, sv. Dujma i sv. Jurja. ${ }^{77}$ Redovnici prije prosjačkih redova (prva polovica 13. stoljeća) imali su svoje posjede kao što su ih imala feudalna gospoda, pa i svoje kmetove. Kada je nestalo redovnika, ostao je feud, imanje koje se kao nadarbina moglo davati raznim institucijama i pojedincima. Budući da je u ovom slučaju riječ o crkvama koje imaju svoj posjed i svoje kmetove, računa se da su to bile nekada benediktinske crkve. Za crkvu sv. Križa imamo podataka iz 14. stoljeća da je bila benediktinska opatija. Poznato je da je kraj Senja bila također benediktinska opatija sv. Jurja. Opatiju sv. Dujma ne nalazimo u vrelima starijim od 1472. godine, a da je bila vezana uz benediktince govori nam upravo činjenica da ima svoje kmetove. Dakako, postoji također mogućnost da se s vremenom počela nazivati opatijskom jer je bila obdarena posjedom i kmetovima kao što je to slučaj s benediktinskim crkvama. Takva "obdarena" crkva svakako je bila ona na "Senjskom brdu" koju su najprije dobili templari, a poslije njih Krčki knezovi, odnosno Frankopani.

Prema dokumentu iz 1515. godine opatija sv. Jurja Lisačkog imala je posjede na Senjskom brdu Chuxova i Nalaze. ${ }^{78} \mathrm{Ne}$ govori se da je ondje crkva

77 "Građani senjski, koli kmetovi senjski toli crikva sv. Križa i sv. Dujma, prosti su od plaćanja svake daće"(M. MAGDIĆ, 1877, 90). "Cives necnon jonagiones tam ipsorum, tam etiam ecclesiarum Sancti Georgii, sanctae Crucis et sancti Duymi exempti ac liberati sunt a solutione cuiuslibet tributi et bonis suis mercemonialibus" (M. MAGDIĆ, 1899, 124).

${ }^{78}$ Kaptolski arhiv Senj (KAS), I, 22. 


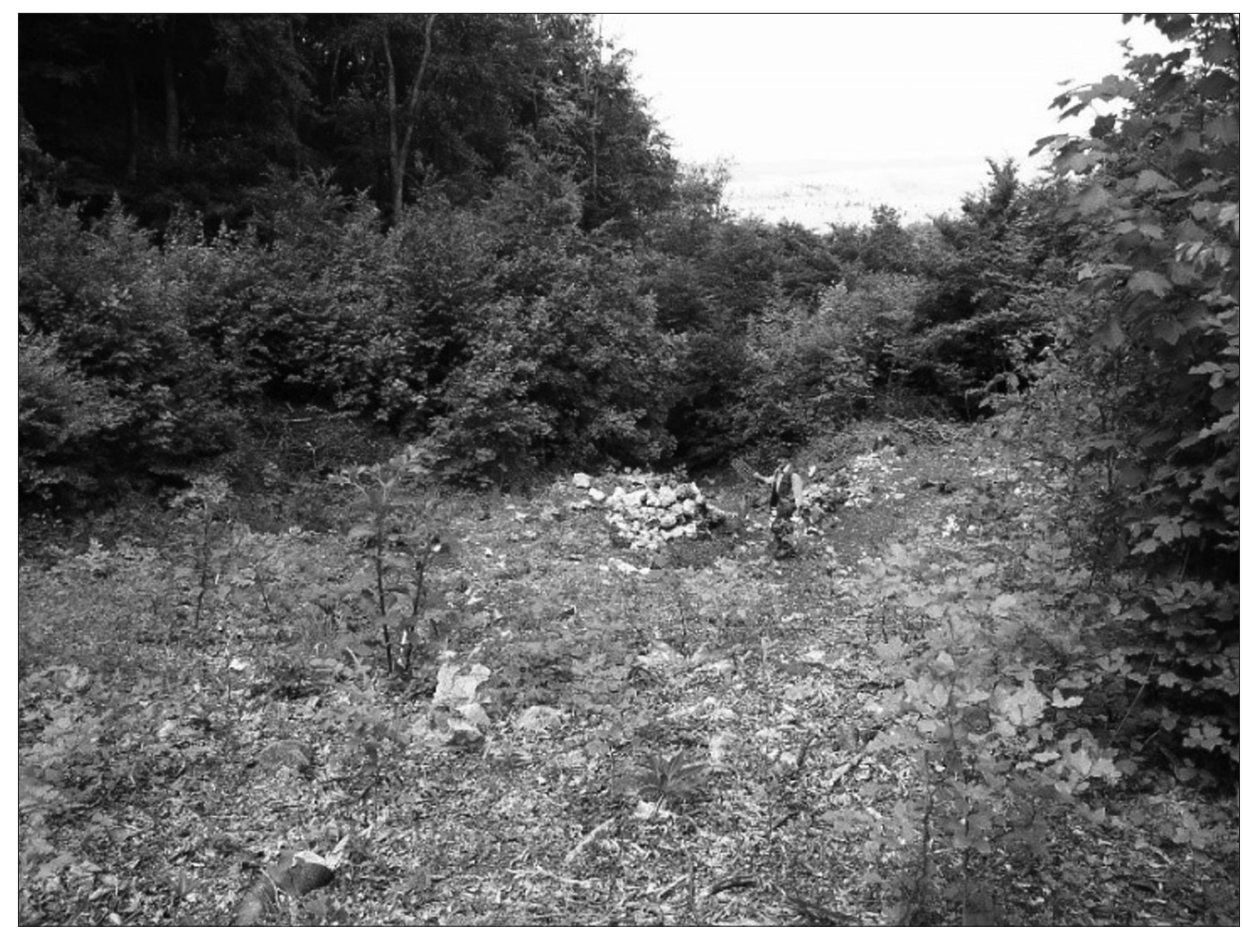

Sl. 17. U potrazi za opatijom sv. Dujma, Francikovac, 2008. (foto: B. Ljubović)

ili samostan. Sljedeći spomen te crkve je 1528. godine kada kralj Ferdinand I. potvrđuje ponovno sve ono što se navodi u ispravi Matijaša Korvina $1472 .{ }^{79}$ Još uvijek ne nalazimo riječ "opatija" uz sv. Dujma.

Prvi spis u kojem se ta opatija izričito spominje potječe iz 29. siječnja 1550. godine kada kralj Ferdinand imenuje Nikolu Barovića ${ }^{80}$ ravnateljem i upraviteljem (rectorem et gubernatorem) opatije sv. Dujma koja se nalazi na Senjskom brdu. Na marginama toga teksta uz ime "sv. Dujma" druga ruka svaki put je dopisala "sv. Jurja". Pored toga, kaže se za opatiju da se nalazi "na senjskom brdu" (in monte Segniensi) ${ }^{81}$ Neki tu opatiju žele smjestiti u Francikovac jer navodno već iz imena proizlazi da se radi o mjestu koje su imali redovnici. ${ }^{82}$

\footnotetext{
${ }^{79}$ M. MAGDIĆ, 1877, 102; M. MAGDIĆ, 1899a, 147.

${ }^{80}$ Druga ruka je na marginama mjesto Barovića stavila: Thomas Kattridaritz, presbytero.

${ }^{81}$ E. LASZOVSKI, MH III, 361.

${ }^{82}$ B. KRMPOTIĆ, 1980, 323; M. SLADOVIĆ, 1856, 246.
} 
Istina je da su ga imali redovnici, ali franjevci (Franciscani), što među ostalim dokazuje i isklesani ljiljan u zidu jedne kuće, a za ljiljan znamo da govori o franjevačkoj prisutnosti. Trsatski franjevci, kao nasljednici senjskog samostana, tek su u prošlom stoljeću prodali posjed u Francikovcu. Pored toga, Francikovac nije "na senjskom brdu" kako kaže spis iz 1550. godine. Teško nam je zamisliti da se u ono vrijeme kada su rušene kuće izvan senjskih zidina može osmisliti neka darovnica za Francikovac.

Teško je nešto suvislo kazati nakon svih tih nepovezanih podataka. Jedna od mogućnosti je da su benediktinci iz Abatova sredinom 14. stoljeća otišli na područje današnjeg Sv. Jurja, ali je ostala njihova crkva sv. Jurja u Abatovu. Da ne budu dvije crkve istog imena u blizini, crkva sv. Jurja koju su templari dobili oko 1184., a poslije Krčki knezovi 1369., preimenovana je u crkvu sv. Dujma. Kako je ona imala sličan status kao i susjedna opatijska crkva sv. Jurja, pridodan joj je naslov opatijske crkve. Iako je ona već 1550 . godine bila ruševina, i dalje su neke nekretnine vezane uz nju. Naime, sam kralj u darovnici spominje da je opatija sv. Dujma nad Senjom uslijed nekadašnjih nemira i ratova pretvorena u ruševine. Neki kažu da se često ime Damjan u izvorima zamijeni s Dujam. U tom smislu navodim kao čistu mogućnost da je ovdje riječ o crkvi sv. Kuzme i Damjana, koja je doista postojala u Senju, o čemu imamo više svjedočanstava, a prvo je dao 1359. godine žakan Kirin koji je u toj crkvi pisao svoj glagoljski psaltir, danas poznat kao Lobkowiczov psaltir. ${ }^{83}$ Crkva sv. Kuzme i Damjana nalazi se u Senju i 1550. godine. ${ }^{84} \mathrm{U}$ novom vijeku često se spominje naslovna opatija sv. Dujma.

Senjski biskup Martin Brajković (1699. - 1704.) u svom izvješću Svetoj Stolici o stanju biskupije piše da su na području njegove biskupije ove 4 opatije: Abbatia Sanctae Crucis, altera sancti Georgii et Tertia S.... penes Segniam, quarta Sancti Nicolai de Gatska in Ottohaz. ${ }^{85}$ Sve tri spomenute opatije, čiji su se naslovi u ovom izvještaju sačuvali, bile su benediktinske. Vjerojatno je takva bila i ona četvrta, kojoj je ime na trošnom papiru propalo. Prvi i jedini komendatarni opat bio je Nikola Barović, 1550. godine. Uz njegovo ime dodano je za istu godinu i ime Tome Katridarića. Poslije toga ne spominje se opatija.

${ }^{83}$ M. PANTELIĆ, 1980, 357. Na povezanost imena Dujam i Damjan upozorio me M. Mihaljević. On misli da je crkva sv. Kuzme i Damjana bila benediktinska jer je Psaltir došao u Češku u vrijeme kad su onamo išli benediktinci iz Hrvatske, noseći sa sobom glagoljske knjige. O rasprostranjenosti patronima sv. Dujma v. A. BADURINA - T. GALOVIĆ, 2014, 415-439.

${ }^{84}$ Vjestnik, II (1900), 1, 48.

${ }^{85}$ M. BOGOVIĆ, 2003, 423. Sladović taj tekst na hrvatskom i treću opatiju je pročitao "Dujma" (M. SLADOVIĆ, 1856, 51). Spominje je poslije i biskup Benzoni u svom izvješću Svetoj Stolici (M. BOGOVIĆ, 2003, 185). Usp. I. OSTOJIĆ, II, 210-2 11. 
Od godine 1836. do Drugog svjetskog rata nosili su počasni naslov Abbas S. Doimi supra Segniam sljedeći prelati:

Nikola Mrzljak, senjski kanonik, 1836. - 1841.

Ignacije Ročić, zagrebački kanonik, 1851. - 1854.

Mihovil Manzoni, senjski kanonik, 1854. - 1873.

Antun Sokolić, senjski kanonik, 1874. - 1889.

Ivan Potočnjak, modruški prepozit, 1894. - 1909.

Ivan Pavelić, modruški kanonik, 1913. - 1919.

Nikola Polić, 1939. arhiđakon ličko-krbavski i župnik u Gospiću (+1940). Za godine 1851., 1874. i 1894. veli shematizam: "vacat".

\section{Templari}

Templari su viteški red koji je nastao u vrijeme križarskih ratova. Osnovao ga je u Jeruzalemu 1119. godine Balduin III. i smjestio ga na istočnu stranu bivšeg jeruzalemskog hrama (templum). Otuda im i ime templari. Samostani im se nazivaju "templa". To je bio ujedno vojnički i monaški red; nosili su redovničku odjeću (bijeli plašt s crvenim križem). Njima je upravljao veliki meštar kome su bili podređeni priori pokrajina, a ovima opet preceptori ili komturi ili upravitelji većeg broja crkvenih imanja. Izravno su bili podređeni rimskim papama, od kojih su bili obdareni raznim povlasticama. Još 1169. godine javljaju se templari u Hrvatskoj pod imenom "božjaci", i to najprije u Vrani (kod Zadra) ${ }^{86}$ koju im je darovao papa Aleksandar III., odakle su se proširili po Hrvatskoj, Slavoniji i Ugarskoj. Glavni samostani u Hrvatskoj su Zagreb, Senj, Božnjakovina i Našice. Kad je papa Klement V. 1312. godine na koncilu u Vienni dokinuo red templara, njihovi su posjedi pripali ivanovcima ili hospitalcima.

Templari dolaze, dakle, u Senj oko 1183/4. godine. To doznajemo iz pisma pape Lucija III. koji im potvrđuje darovnicu kralja Bele III. ${ }^{87}$ Nije nam poznata kraljeva darovnica pa ne znamo točno njezin opseg. U papinu pismu stoji da templarima pored Senja pripada i crkva sv. Jurja. Međutim, kada 1209. godine kralj Andrija II. potvrđuje darovnicu svoga prethodnika, on kaže da je Bela darovao templarima Senj, a splitski nadbiskup crkvu sv. Jurja koja se nalazi

\footnotetext{
${ }^{86}$ Usp. T. GALOVIĆ, 2017, 239-255.

87 "Vestris justis postulationibus grato concurrentes assensu vilam Signye a charissimo in Christo filio nostro Bela... illustri Hungarie rege cum omnibus petinenciis pia domui vestre liberali tete collata cum ecclesia sancti Georgii et omnibus, que in eodem loco de donatio ne regia rationabiliter possidetis, vobis et successoribus vestris apostolica auctoritate confirmamus" (CD II, 191).
} 


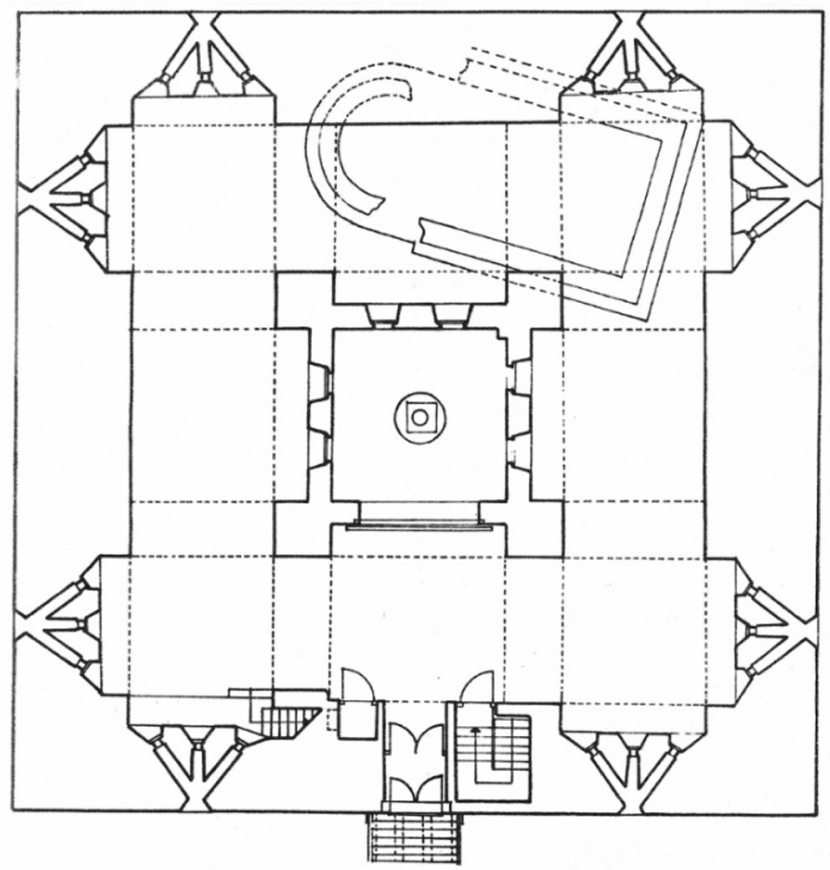

S1. 18. Tlocrt prizemlja Tvrđave s temeljima crkve sv. Jurja iz 11./12. st. (izvor: M. VILIČIĆ, 1971.)

na području koje pripada istom gradu.$^{88}$ Vjerojatno je Andrija imao pred sobom tekst Beline darovnice pa je mogao točnije navesti tko je što darovao. Uz to, valja spomenuti da je u prvoj darovnici Senj naselje (villa), a u drugoj je već grad (civitas). Kralj uzima u zaštitu templare po Dalmaciji i Hrvatskoj i naređuje da se templara ne smije ničim teretiti niti od njih uzimati nikakve daće.

Koja je to crkva koju su templari dobili? Najvjerojatnije je to crkva koja je otkrivena pod temeljima Nehaja. Ona je stradala 1522. godine kada su Turci

88 "Civitas vcro Scev, quam eis illustris B(ela) rex pie recordations in puram contulit elemosinam cum omnibus appendiciis suis, silvis scilicet et pascuis ceterisque ad jus regale spectantibus, ipsis fratribus semper firma permaneat et jure perpetuo inconcussa cum ecclesia beati Georgii in ei usdem civitatis territorio sita, quam eis Petrus archiepiscopus Salonie dedit, consistat" (CD III, 85-86). "In eiusdem civitatis territorio" treba shvatiti "na području koje pripada gradu Senju, a ne da je crkva unutar samoga grada. Senj najkasnije od 1169. godine ima svoga biskupa Mireja, ali je on jedno vrijeme bio suspendiran jer se sporio s ninskim biskupom za Liku (M. BOGOVIĆ, 2017, 32). Vjerojatno je zato darovnicu za crkvu sv. Jurja izdao metropolit u Splitu. Mireju je vraćena uprava biskupije 1179. godine pa je vjerojatno da je darovnica metropolita bila te godine ili nešto prije. 


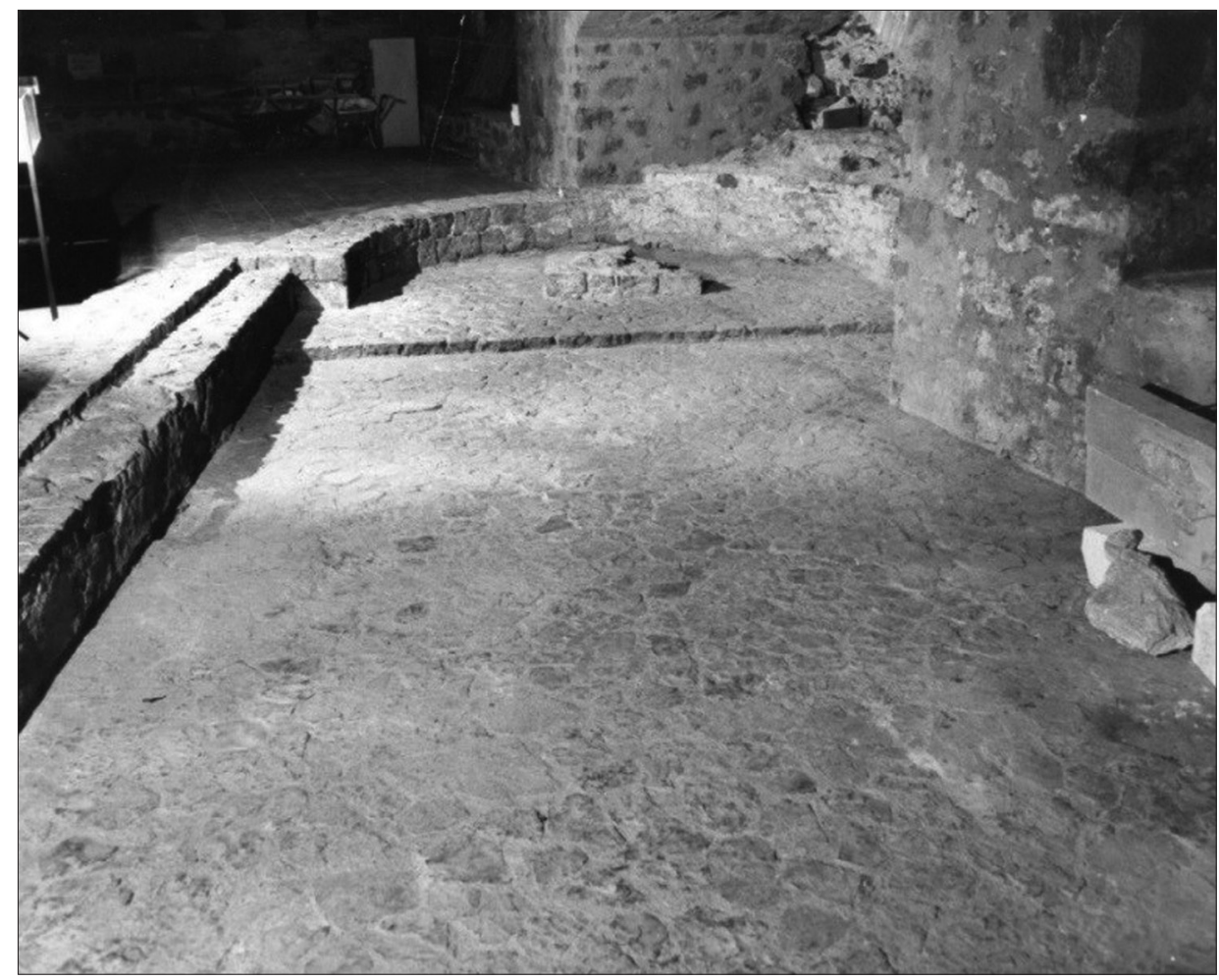

Sl. 19. Tvrđava Nehaj, temelji crkve sv. Jurja iz 11./12.st. (izvor: Gradski muzej Senj)

napali Senj, a srušena je 1540. godine radi gradnje tvrđave. Kao što su u to vrijeme porušene i druge crkve izvan zidina i neke od njih sagrađene unutar zidina (sv. Franjo, Sv. Duh), zacijelo je grad Senj sagradio novu crkvu (sličnih dimenzija) u srcu grada (uz katedralu).

Teško je prosuditi kakva su prava dobili templari nad Senjom i okolinom. Najprihvatljivije rješenje ponudio je Vjekoslav Klaić. Po njemu, Senj je u vrijeme templara bio najveće naselje u podvelebitskom kanalu, s biskupskim sjedištem, poznata drvna luka na Jadranu. Imala je svoje brodogradilište (škver) za trgovačke i ratne brodove: "Vjerojatno da su Templari držali samo gradsku tvrđu, kao i teritorij u okolišu gradskom, te pobirali neke dohotke gradske, dočim su se građani upravljali sami, sastajući se u vijeće, te birajući sami svoje sudce (judices). Čini se da su građani već tada imali svoj općinski 


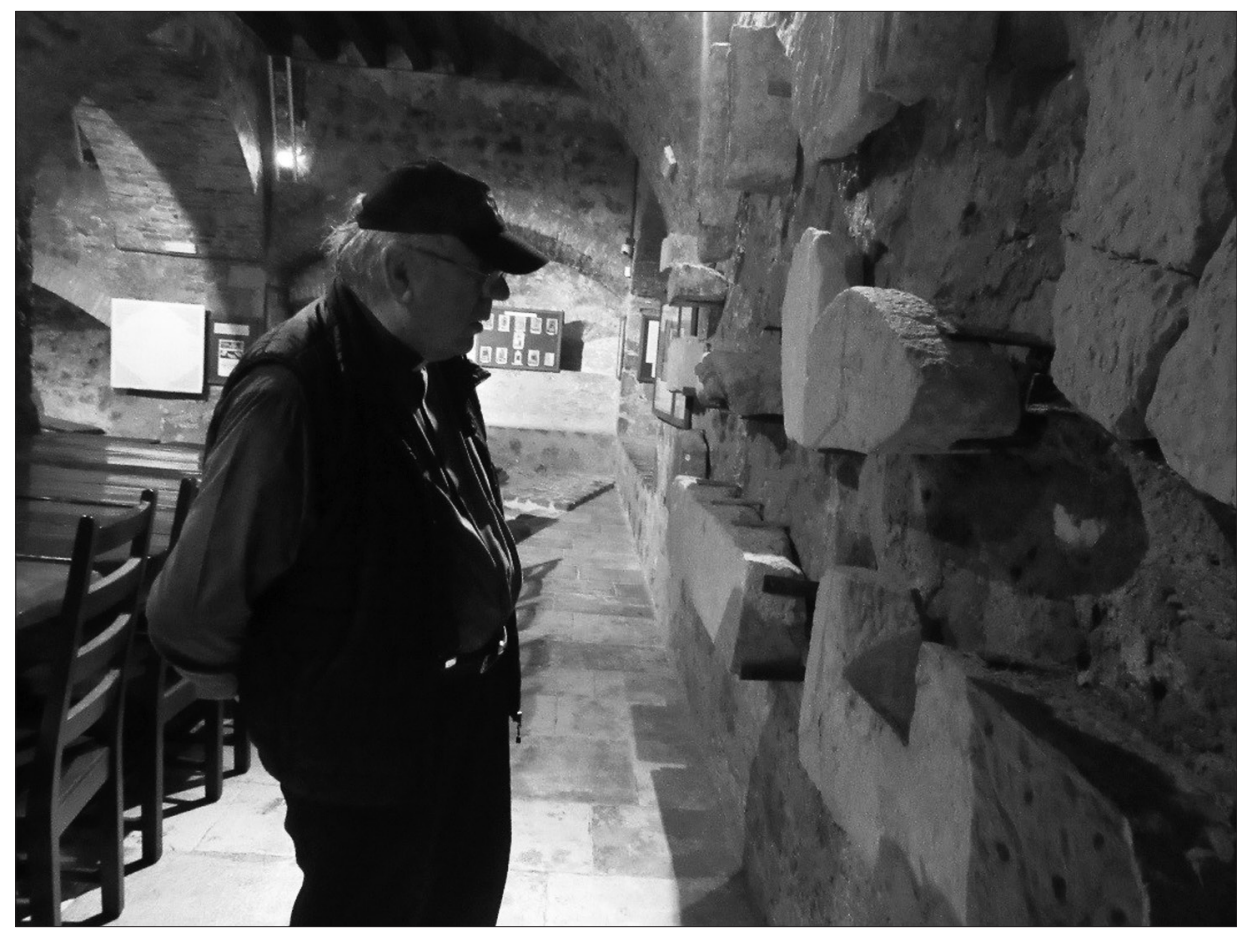

Sl. 20. M. Bogović ispred spolije na kojoj je uklesan križ (templarski?)

13. svibnja 2020. (foto: B. Ljubović)

pečat (sigillum communitatis Svenyensis) sa slikom sv. Jurja, kako sjedi na konju i udara na zmaja."89

Senj je imao organiziranu gradsku općinu i senjski kotar; bio je u 12 . stoljeću starohrvatska županija ili knežija koja je međašila sa Vinodolskom, Gatanskom i Buškom župom, a uz obalu se prostirala od Ledenica na sjeveru i do Stinice na jugu. Senj je bio u vlasti viteškog reda templara od 1184. godine kad im ga je darovao hrvatsko-ugarski kralj Bela III. i splitski nadbiskup Petar sa crkvom sv. Jurja i sa svim pašnjacima i ostalim pravima. Stalan, skoro 85-godišnji boravak templara u Senju i njihovo vršenje kraljevskih prava nad gradom preobrazili su politički i kulturni, ekonomski i crkveni život u Senju i na njegovom kotarskom području. Naskoro im se za to pružila prilika.

${ }^{89}$ V. KLAIĆ, 1899, 269. Nada Klaić smatra da je kralj mogao u Senju predati templarima samo one prihode koje je sam imao jer je Senj bio "mala zrela komuna". Templari su u Senju mogli ubirati samo "trgovinu" (N. KLAIĆ, 1988, 52, 56). 
Kad je ugarsko-hrvatski kralj Andrija II. 1217. godine pošao na križarsku vojnu u Svetu Zemlju, postavio je u Hrvatskoj i Dalmaciji za kraljevskog namjesnika templarskog velikog meštra Ugarske, Hrvatske i Slavonije i preceptora senjskih templara Poncija de Cruce. Još prije toga bio je Poncije de Cruce u Veneciji gdje je sakupio brodovlje za transport četa u Svetu Zemlju. Kralja je na toj vojni križarskoj izdašno pomogao i krčki knez Vid II. sa svojim mlađim bratom Henrikom. Možemo pretpostaviti da su se vojni priključili i neki templari iz Senja (iako nemamo za to potvrdu u izvorima). ${ }^{90}$ Veliki je meštar Poncije de Cruce sretno izvršio sve zadaće koje mu je povjerio Andrija II., pa je kralj po svome povratku kao nagradu za zasluge i odštetu za velike troškove što ih je imao veliki meštar templara u Hrvatskoj i Ugarskoj 1219. godine obdario templare mnogim posjedima, a senjskim templarima dao čitavu Gatansku županiju (Gacku dolinu), koja je tada u crkvenom pogledu spadala pod senjskog biskupa. Tako je i pod političku vlast Senja došao sav teritorij na kojem se iz tog centra vršila crkvena uprava i time se integriralo čitavo gravitacijsko područje Senja, kakvo je ostalo tijekom povijesti.

Ovakva velika moć templara morala je doći u sukob sa sve snažnijim susjedima feudalcima Krčkim knezovima koji su 1193. dobili od kralja Bele III. županiju Modruš, a 1225. godine od kralja Andrije II. Vinodol. Krčki knezovi nastojali su da pod svoju vlast ili barem pod svoj utjecaj dobiju grad Senj i Gacku dolinu. Senj je bio ključ i prolaz u njihovu modrušku župu; priželjkivali su kako bi se sjedinio sav taj veliki posjed na hrvatskom kopnu. Zato nastaju u Senju česte smutnje i nemiri, koje su nerijetko poticali Krčki knezovi. Senjski su templari bili većinom tuđinci te se nisu mogli složiti sa susjednim velikašima i plemenima, već su s njima živjeli u trajnim zadjevicama i neprijateljstvu. Senjani su 1220. godine počinili, kako kaže Vitezović, velika nasilja na moru da su sve obližnje narode natjerali u strah. ${ }^{91}$ Sve su više rasle i napetosti između senjskih građana i njihovih gospodara templara.

Sačuvan nam je dokument koji govori da je "pred templarskom crkvom" 13. lipnja 1233. godine održano sudište. ${ }^{92}$ Zacijelo su templari smatrali to mjesto na Senjskom brdu pogodno za donošenje važnih odluka.

Prijelomna godina u odnosima Senja i templara jest 1239. Izvori govore da je te godine u prosincu grad bio osvojen i zapaljen..$^{93}$ Povjesničari su to dosad uglavnom tumačili navalom nekoga vanjskog neprijatelja na Senj i templare, a kao

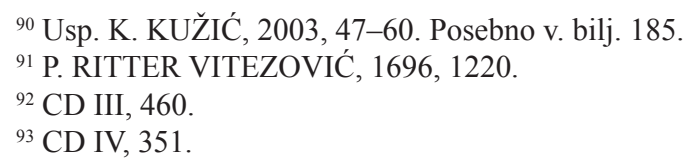


najvjerojatniji neprijatelj spominje se Venecija. Ipak mi se čini najvjerojatnijom mogućnost, na koju ukazuje Margetić, da su zapravo templari osvojili i zapalili grad. Budući da oni, kaže Margetić, nisu imali vlast u samom gradu, kada su Senjani i strani trgovci odbili plaćati templarima podavanja iz trgovačkog prometa, odlučili su ovi silom ući u grad i zaplijeniti robu na koja nisu plaćena dužna podavanja. Tom prilikom došlo je i do požara u gradu. Margetić u tom događaju vidi "labuđi pjev" templara u Senju. ${ }^{94}$ Vjerojatno su to osjetili i senjski templari i o tome obavijestili glavni kapitul hrvatskih templara koji se 1240. godine održavao u Glogovnici. Među ostalim spomenuto je da je prije nekog vremena topuski opat zamolio templarskog meštra za Ugarsku Rebmalda de Karumpe da se cistercitskoj opatiji u Topuskom ustupi jedno mjesto kraj Senja gdje bi cisterciti napravili sebi kuću koja bi im služila za prodavanje svoje robe i kupovanje što je njima potrebno. Skupština je jednoglasno odobrila molbu i dopustila da se topuskoj opatiji ustupi polovicu parcele koju je koristio prior Oprahk, ali pod uvjetom da cisterciti ne smiju ondje kupovati i primati druge terene i vinograde bez suglasnosti templara, a trgovati mogu samo za svoje potrebe. Ako templari u Senju izgrade trgovačke zgrade, moći će ondje cisterciti prodavati svoju robu i kupovati onu koja je na raspolaganju bez ikakvih nameta. ${ }^{95}$

Senjski su templari upali i u kraljevu nemilost, što bi moglo biti povezano ne samo s napadom na Senj nego i još prije s njihovim držanjem u vrijeme mongolske provale. Kako nam je poznato, nakon što su se Mongoli povukli, kralj se pokazuje vrlo darežljivim prema Krčkim knezovima jer su mu oni pritekli u pomoć kada je morao bježati pred Mongolima. Iako nemamo izravne potvrde da je izostala slična pomoć templara ${ }^{96}$, napad bana Stjepana (Babonića)

${ }^{94}$ L. MARGETIĆ, 1985-1987, 24. Margetić je dosta nejasan u pitanju ustrojenosti i moći senjske općine. Jednom u organiziranoj općini templari imaju slaba prava (Nav. dj., 23), a na drugom općina je tek 1271. godine pokazala da ima svoje organe vlasti i uprave (Nav. dj., 29).

95 "postulassent ... locum unum apud Sceigniam" (CD IV, 109-110). Obično se drži da je to mjesto bilo na području današnjeg Sv. Jurja i da su cisterciti sagradili sebi ondje kuću, a kraj nje i crkvu sv. Filipa i Jakova. Zorislav Horvat kaže da je gradnja te crkve u stilu drugih cistercitskih crkava. Misli da su još u to vrijeme senjski templari planirali napustiti Senj pa su svoja dobra prodavali benediktincima i cistercitima (Z. HORVAT, 2001, 28-31).

${ }^{96}$ Usp. Lujo MARGETIĆ, Izvještaj Ivana Tomašića o Grobničkoj bici, Grobnički zbornik, 2, Rijeka, 1992, 28-34. Margetić iz činjenice da je Bela IV. tražio pomoć od nekih država i od templara (koji su kod Tomašića nazvani Rođani), zaključuje da templari nisu kralju pružili traženu pomoć (Grobnički zbornik, 2, str. 14). Taj autor se jako trudi da dokaže kako nije bilo nekih žešćih sukoba s Mongolima. Ako je i bilo, oni su bili negdje drugdje, a ne na kvarnerskom prostoru. U jednom drugom radu (Vijesti iz vjerodostojnih i krivotvorenih isprava o provali Tatara u hrvatske primorske krajeve 1242., Radovi Filozofskog fakulteta Zagreb, 25, Zagreb, 1992, 5-14), ne spominje dokument iz CD IV, 35 u kojem se govori da su templari i monasi Sv. Jurja u vrijeme 
na templare po kraljevu nalogu ${ }^{97}$, ubrzo nakon mongolskog povlačenja, daje nam pravo da te dvije stvari uzročno-posljedično povežemo. Sukob se izrodio u krvave okršaje plemena Babonića sa Senjanima jer je zacijelo rat prešao granice ciljeva koji su bili razlogom sukoba. Važno je uočiti da sugovornici Babonićevi kod sklapanja mira nisu templari, nego predstavnici senjske općine koja ugovor potvrđuje svojim pečatom. ${ }^{98}$ Među brojnim svjedocima nalazi se i "capitulum templariorum", što znači da templari već tada u Senju vrlo malo znače. I na općem planu templari u to vrijeme ne uživaju nekadanji ugled, pogotovo nakon što su kršćani zbog njihove nerazboritosti pretrpjeli 1244. godine teški poraz kod Gaze. Senj se izgleda dosta brzo oporavio nakon požara u prosincu 1239. godine, a za vrijeme tatarske provale nije imao većih šteta. Teško bi inače bilo razumljivo da već 1248. godine Katalonci imaju u Senju svoj konzulat kako bi se što bolje regulirala i zaštitila njihova trgovina. ${ }^{99}$

Za vrijeme kraljevanja Bele IV. (1235. - 1270.) doživio je Senj novu nevolju. Kad su, naime, Mongoli pod Batu-kanom pobijedili ugarsku vojsku i počeli nemilosrdno po čitavoj Ugarskoj ubijati narod, paliti sela i gradove, pobjegao je kralj Bela IV. sa svojom pratnjom preko Zagreba u Senj i odatle dalje da potraži utočište u utvrđenim dalmatinskim gradovima. Tom su zgodom Tatari doprli do grada Senja, ali ga nisu zauzeli. Za vrijeme opsjedanja izgorio je jedan dio grada, a mnogi stanovnici izgubiše u tom metežu život. Senjski pučani orobiše tada bogate dućane krčkih, rapskih i talijanskih trgovaca i zbog te pljačke zavadi se senjska i mletačka stranka te zavlada veliko i dugo neprijateljstvo između Mlečana, Krčana i Rabljana s jedne strane i Senjana s druge strane.

Mletački dužd 1248. godine zaštićuje svoje podanike u Senju od šteta koje su pretrpjeli u Senju za vrijeme senjskog požara i tatarske provale. Dana 25. travnja spomenute godine sklapa mletački dužd u ime Krčana s preceptorom senjskih templara Jakobom Turriselis nagodbu kojom se templari obvezuju da će u ime štete što je učinjena mletačkim, krčkim i rapskim trgovcima prigodom opsjedanja i požara platiti mletačkom duždu ili njegovom nasljedniku 5.250

tatarske provale pobjegli na Krk. U slučaju da je tada senjski kraj bio opustošen, kako govore neki izvori (usp. bilj. 45), onda je velika vjerojatnost da su veliki okršaji s Tatarima bili upravo na kvarnerskom području.

${ }^{97}$ Riječ je o neprijateljstvima "inter generacionem comitis Babonek et Stephani bani et populum Sceniensem exortis iuxta templarios per preceptum domini regis" (CD IV, 181). Mir je sklopljen u veljači 1243. godine, dakle, ubrzo nakon povlačenja Mongola.

${ }_{98}^{98}$ Taj nam se pečat nije sačuvao. Sačuvao se na povelji od 1268. godine. Pečat je okrugao. U sredini je sv. Juraj u borbi sa zmajem, a okolo je natpis: $\uparrow$ S. COMVNIS CIVITATIS D SCENIA (CD V, 475). Usp. A. GULIN, 1993, 55-78.

${ }^{99}$ Radojica F. BARBALIĆ, 1970, 7. Godine 1275. učinila je sličan korak i Venecija. 
libara u malim mletačkim dinarima, a monasima sv. Jurja (benediktincima), koji su se također bili sklonili u Bašku, trebaju Bašćani nadoknaditi štetu. Nakon sklopljene nagodbe godine 1248. opet je otpočelo naseljavanje u Senj trgovaca i obrtnika s mletačkog područja Venecije i Ancone i drugih, sjevernih talijanskih gradova. U gore spomenutom dokumentu iz 1248. godine u dvjema nagodbama između Mlečana i templara spominju se benediktinski samostan sv. Jurja i benediktinci (monasi). ${ }^{100} \mathrm{U}$ nastojanju Senjana da se oslobode templara imali su oni podršku, kako je rečeno, upravo Krčkih knezova koji su malo pomalo, uz kraljevu naklonost, preuzimali u Senju ulogu koju su imali templari. Nepovoljna je za templare mogla biti i činjenica da su oni, kako stoji u ugovoru iz 1248. godine gdje se govori o zauzeću i spaljivanju Senja, u vrijeme tatarske provale, pobjegli na Krk. ${ }^{101}$ Neobično je da se u ratu vitezovi igraju skrivača. Iako Senj tada Mongoli nisu uspjeli osvojiti, templari ne vide da bi sebe i svoje blago mogli zaštititi u njemu. ${ }^{102}$ To sve upućuje na zaključak da su Senj 1239. godine zapalili templari, odnosno da su oni za to krivi. Kad bi to bio netko drugi, zašto bi baš templari trebali plaćati štetu mletačkim, rapskim i krčkim trgovcima koji su također tada bili oštećeni. Ne kaže se da štetu treba platiti senjska općina, nego upravo templari.

$\mathrm{U}$ to vrijeme bilježimo i na drugim mjestima sukobe s templarima. Ni pape ni kraljevi ne pružaju im više onakvu potporu kakvu su im pružali u prošlim vremenima. U tim okolnostima opada važnost templara. Bela IV. je čak povukao sve darovnice koje su njegovi prethodnici dali u prilog templara. Na pritisak sa strane on je, doduše, spomenute darovnice obnovio, što je papa 1253. godine potvrdio, ali jasno je bilo da oni više ne uživaju onakvu podršku kakvu su

${ }^{100}$ Monasi "qui fugiebant a Tartaris ex monasterio sancti Georgii" (CD IV, 459-460). Neki to krivo shvaćaju da su templari iz samostana sv. Jurja. Govori se o "monasima", što templari nisu.

${ }^{101}$ CD IV, 351. Jasno je da takvo zaključivanje ostavlja iza sebe dosta nedokazanoga, jer nije rečeno da su svi templari pobjegli.

${ }^{102}$ Tako bi izgledalo po onome što smo u citiranoj građi našli. Magdić, doduše, kaže da je jedan dio grada i tom zgodom izgorio (M. MAGDIĆ, 1877, 53). Aleksandar Buczynski prikazuje stvar u sasvim drugom svjetlu. On kaže: "Četrdesetih godina trinaestoga stoljeća Tatari su opustošili cijelo područje oko Senja. Tamošnji su stanovnici bili protjerani, ubijeni, ili odvedeni u roblje. Da bi se ovo područje ubuduće bolje moglo obraniti od sličnih napada i zato da bi ga ponovno napučili, Krčki su knezovi Frankopani svoje tamošnje primorske posjede odlučili naseliti porodicama sa susjednih otoka. Tim je porodicama stavljeno na raspolaganje nenapučeno područje, zajamčena im je sloboda od svih davanja, uz jedinu obvezu da područje besplatno brane u slučaju napada s kopna ili mora. Zbog toga su ih u frankopanskim povlasticama iz idućih stoljeća nazivali senjskim vojnicima." (A. BUCZYNSKI, 1997, 10). Prije nego se provjeri vrela na kojima se temelji takva tvrdnja u tako nešto ne možemo povjerovati. 
uživali za vrijeme njegova oca Andrije. ${ }^{103}$ Još očitije to proizlazi iz listine od 21. svibnja 1257. godine iz koje se vidi da je još tada krčki knez Fridrih bio kraljev povjerenik i senjski načelnik. ${ }^{104}$ Templarima su se i dalje nastavila osporavati njihova prava na Senj i Gacku. Spor se vodio upravo između templara i kralja, a nakon što je Bela IV. povjerio upravu Hrvatske i Slavonije hercegu Beli, očito je bilo na templari nemaju njegovu podršku. Stvar je uzela u svoje ruke papinska kurija, kamo su jedna i druga strana poslale svoje opunomoćenike. Preceptor za Ugarsku i hrvatsku, Franko, otišao je na generalni sabor reda u Akkon gdje mu je dana punomoć da u toj stvari zastupa red. Dogovoreno je da se templari odreknu svojih prava na Senj i Gacku, a za uzvrat dobivaju županiju Dubicu sa svim pripadnostima te uz to 1500 maraka u srebru. ${ }^{105}$ Nije jasno što je kraljevska kuća imala protiv templara. Moguće je da je već dala neka obećanja za Senj i Gacku Krčkim knezovima i da su oni u pozadini tog spora s templarima. Što se tiče Senjana, oni su svojim postupcima templarima najviše zagorčili boravak. Templari su se poslije tužili da zbog njihove zlobe ondje nisu više mogli opstati pa zato svojevoljno prekidaju spor i odriču se svih prava koja su im pripadala u gradu Senju i okrugu te na posjedu i okrugu Gacka; odriču se također i svega što su im do tada s obzirom na Senj i Gacku darovali ugarski kraljevi i hercezi te pape. Zato dobivaju 1269. godine županiju dubičku. ${ }^{106}$

Slabija podrška viteških redova sa strane crkvenih vlasti ima svoje korijene i u tome što je sada papinstvo dobilo nove snage kojima povjeravaju ključna mjesta u svojoj strategiji obnove i obrane kršćanstva. To su prosjački redovi franjevci i dominikanci. Oni nisu vojnici, ali ipak vode ne samo misije nego i inkviziciju. Već se tada nalaze na najvažnijim i najosjetljivijim mjestima.

${ }^{103} \mathrm{U}$ svojoj potvrdnici papa Inocent IV. piše: "Magistro et fratribus militie Templi in Hungaria et Sclavonia" da je kralj Bela IV. "omnes donationes et concessiones ... a predecessoribus suis factas revocandas duxisset", ali je sam poslije iste darovnice potvrdio. (G. FEJÉR, 1829, 203).

${ }^{104}$ Oštećeni Dubrovčani zbog arboratika pozvali su se "ad dominum Federicum supraddictum vicarium domini regis et potestatem Segnijensem". (CD V, 66)

${ }^{105}$ I. KUKULJEVIĆ, 1895, 91-92. Taj spis izgleda kao neki zapisnik. CD ga ne objavljuje, valjda ga drži sumnjivim. Objavio ga je A. Theiner u Vetera monumenta historica Hungariam sacram illustrantia, I, Romae, 1859, p. 311. U CD V, str. 510-513 objavljena je darovnica Bele IV. od iste godine, u kojoj su detaljno opisane granice dubičke županije i prava koja templari ondje imaju.

106 "Idem autem magister et fratres considerantes, cum apud Seniam proptrer malitiam civium profecere non possent, ceserunt spontanea voluntate ob omni lite, et omni juri quod domui Templi competebat in predicta civitate Scenia, districtu, honore, vectigalibus et tributis, et in tota possessione ac districtu de Guechke, renuntiantes etiam omnibus instrumentis, privilegiis etc summorum pontificum et regum Belae III, Andreae et Belae IV ac Colomani regis Ruthenorum et ducis Slavoniae, super Scenn et Guechke". (Usp. I. KUKULJEVIĆ, SAKCINSKI, 1886, 26-27). Ne navodi odakle je taj citat izvukao. 
O broju templara u Senju nemamo podataka. Budući da je ondje bio preceptorat, jamačno nisu u Senju bili samo pripadnici upravnoga kadra i činovništva, nego i templari vojnici, a za neki konkretniji i precizniji zaključak nemamo podataka. Ako je bilo vojnika, po svoj prilici su se oni priključili kralju Andriji II. koji je 1217. godine prolazio kroz Hrvatsku da se priključi petom križarskom ratu. Svakako nije prošao kroz Senj, a nije poznato da je bilo koji križarski put išao kroz Senj. Kroz senjski kraj prolazila je jedna skupina križara 1096. godine, ali tada još ondje nisu bili templari. ${ }^{107}$

\section{b) Franjevci}

\section{Život franjevačkog reda u Senju ${ }^{108}$}

Čovjek je sklon da si osigura ugodan i lagodan život na ovome svijetu do te mjere da i ne želi nešto bolje i više. Ideal je sve imati na raspolaganju i ne biti ovisan ni o kome. Takve sklonosti obuzimaju i kršćanina pa mu onda izblijedi slika drugoga svijeta i želja da svoje korake usmjeruje prema njemu. Te sklonosti razvile su se i u kršćanima srednjega vijeka. No, bilo je ljudi koji su u tome vidjeli jačanje duha ovoga svijeta, a slabljenje duha evanđelja, duha Kristova, duha siromaštva i duha služenja. Takav pogled na svijet promiču prosjački redovi, u prvom redu franjevci koji su to ime dobili jer su slijedili sv. Franju. Franjo želi slijediti siromašnog Krista, onoga koji nije došao da mu služe nego da on služi, kojega ovaj svijet ne zarobljava svojim ponudama, već stalno čezne za onim svijetom u kojemu Krist čovjek živi. Tako je Franjo bio obuzet Kristom da je i on dobio na tijelu rane koje je Krist dobio kad su ga na križ pribijali. Mnogima je otvorio oči i krenuli su za njim.

Franjini nasljednici, franjevci, došli su u Senj ubrzo nakon odlaska templara. ${ }^{109}$ Moguće je da su stigli još za biskupa Filipa. On je, naime, zajedno s gvardijanom splitskoga franjevačkog samostana 1248. godine dobio zadatak da ispita pravovjernost bosanskog bana Mateja Ninoslava. ${ }^{110}$ Kako su tada takve zadatke pape povjeravali najčešće prosjačkim redovima, lako bi moglo biti da je i Filip iz njih izišao. Drugim riječima, papa Filipu povjerava "franjevački" zadatak. Toma Arhiđakon nabraja 1266. godine biskupe koje je unutar svoje metropolije splitski nadbiskup posvetio ili instalirao. ${ }^{111}$ Budući da među nabrojenima novim

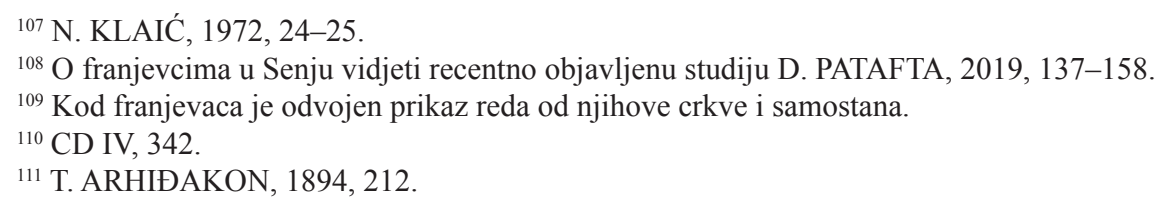


biskupima nema spomena senjskog, pretpostavlja se da je tada Filip još ̌̌iv ${ }^{112}$, što znači da su franjevci vjerojatno došli u Senj još dok je on upravljao biskupijom. U Bosni su već dominikanci, a već se pripremaju da onamo idu i franjevci jer ovi prvi nisu ispunili očekivanja.

Godine 1269. templari su dobili nadoknadu za Senj, a sva je prilika da su iz njega otišli i prije. Prava koja su oni imali nad Senjom i okolicom postupno su preuzeli Krčki knezovi. Ovi su ubrzo u Senj doveli franjevce. Budući da je odlazak templara i dolazak franjevaca vremenski vrlo blizak, nije bezrazložno misliti da su franjevci došli upravo na ono mjesto gdje su prije bili templari. Tako u stvari franjevci, a ne benediktinci, dolaze na njihovo mjesto. Kao gospodari grada jasno je da su templari bili ondje gdje će se postupno razviti kaštel. Gospodarske kuće bile su im na prostoru današnje Travice, tj. na prostoru gdje su se poslije nastanili franjevci i sagradili sebi ondje crkvu i samostan.

Nakon kršćanskog vojnika redovnika templara, na vratima grada Senja pojaviše se franjevci, učenici sv. Franje iz Asiza. Franjo se također u mladosti oduševljavao viteškim i križarskim duhom svoga vremena, ali je naglo izgubio volju za nadmetanju u vještini i snazi i za zabavama koje je nudio tadanji svijet i krenuo na put ovisnosti o drugima, siromaštva i služenja. On je toj novoj spoznaji tako dosljedno služio da su mnogi prepoznali u njegovom putu i svoj put. Franjevci su dobili podršku službene Crkve i tadašnjeg društva i svuda su ih lijepo primali. Nastanili su se u predgrađima gdje ima najviše sirotinje. Tako se zaustaviše i pred Senjom, na kraju puta koji vodi iz Slavonije preko Vratnika u primorje. To je prostor današnje Travice.

Može se reći da se i u Senju dogodilo ono što se zbilo i na planu opće Crkve: viteške redove nasljeđuju prosjački redovi. To je jedan zaokret u povijesti Crkve, a taj se zaokret na isti način dogodio i u Senju. O franjevcima u Senju sačuvano nam je relativno dosta izvornog gradiva zahvaljujući činjenici da je ono nakon zatvaranja samostana u Senju preneseno u trsatski samostan. O samostanu i crkvi imamo također više radova koje ćemo spomenuti i koristiti u ovom prikazu. Valja posebno istaknuti rad Mihovila Bolonića ${ }^{113}$ i Daniela Patafte. ${ }^{114}$ Neki kažu da stari franjevački samostan u Senju "bliz je vremenima serafskog oca sv. Franje"115, ali o tome nemamo potvrde u starijim spisima.

${ }^{112}$ U rujnu 1268. godine u diplomi utanačenja mira između Raba i Senja spominje se u Senju "segniensis J. archidiaconus, Crossicius archipresbyrer" (CD V, 475), ali se ne spominje biskup. Moguće je da je Filip već umro ili je premješten na drugo mjesto.

${ }_{113}$ M. BOLONIĆ, 1973, 254-265.

${ }^{114}$ D. PATAFTA, 2019, 137-158.

${ }^{115}$ BAS, fasc. III B, br. 7. od 30. XII 1774: De origine conventus Segniensis Franciscanorum fundatione. 
Franjevci su u Senju svakako prije 1272. godine jer te godine oni imaju već sagrađenu crkvu. Dvadeset godina kasnije (1292.) imaju sigurno i samostan, a 1298. bila je posvećena nova crkva. Marijan Žugaj nagađa da je veoma rano taj samostan imao školu za svoje kandidate jer se 1245. i 1260. godine spominju lektori u samostanu. ${ }^{116}$

Na prostoru na kojem su franjevci imali crkvu i samostan bilo je dosta kuća, ali građenih ne u gradskom, već prigradskom stilu, gdje su uz kuću i vrtovi za obrađivanje. Pored vrtova i obradive zemlje dobivali su franjevci i kuće koje su iznajmljivali i od toga živjeli. Tako darovnicom od 18. travnja 1292. godine (izdanom u Senju) neki Krčanin Mihovil de Vezanello dariva samostanu male braće u Senju "neku svoju kuću u Senju" u blizini kuća kneza Leonarda. ${ }^{117}$ Ako pretpostavimo da su darovani vrtovi i kuće u blizini franjevaca, moglo bi se reći da su i franjevci blizu kućama kneževa. To kažem zato jer je od tih kneževih kuća nastao poslije kaštel, pokraj Travice. Najvjerojatnije da su Krčki knezovi imali svoje kuće gdje je s vremenom nastao kaštel, što opet upućuje na prostor Travice kao mjesta franjevačke crkve i samostana.

Iako se iz suvremenih izvora ne može prepoznati da su Krčki knezovi sagradili franjevcima samostan i crkvu, ipak se iz tih izvora može naslutiti određena povezanost te obitelji s franjevcima u Senju. Navest ćemo nekoliko takvih izvora. Knez Ugrin, prijatelj kneza Ivana, uz suglasnost kneza Leonarda i njegova nećaka Bartola daruje franjevcima vrt blizu mjesta senjskih franjevaca. ${ }^{118}$ Elizabeta, žena pokojnog kneza Dujma, predaje 2. ožujka 1350. godine senjskim franjevcima jednu kuću u Senju koju im je njezina majka Jelena, nekoć hrvatska banica, u svojoj oporuci ostavila. ${ }^{119}$ Ista Elizabeta daruje 20. rujna 1353. godine vinograd i kuću franjevcima u Senju. ${ }^{120}$ Krčki knez Bartol, otac Stjepana i Ivana, dao je franjevcima jednoga kmeta u Gackoj. Otac je umro, a braća su se podijelila pa Stjepan na mjesto svoga dijela (duga) daje 12. kolovoza 1365. godine franjevcima u ime svoje i u ime svojih nasljednika prinos 50 solida u ime otkupa za polovicu kmeta aktualnog tečaja, a svaki mjesec će dobivati od njega i

${ }^{116}$ M. ŽUGAJ, 1989, 150.

${ }^{117}$ CD VII, 81.

${ }^{118}$ Ugrin "cum consensu et voluntate comitis Leonardi et comitis Bartoli nepotis sui" daruje franjevcima vrt "prope locum fratrum minorum de Segnia". (CD VII, 21-29)

${ }^{119}$ Godine 1350., 2. ožujka. "Elizabet relicta olim bone memorie domini comitis Duymi" daruje "ecclesiae fratrum minosrum de Segnia unan domum ... quam domum domina Elena genitrix dicte domine Elizabet, olim Croatorum banissa eidem ecclesiae in suo testamento legavit" (CD XI, 584-585).

${ }^{120} \mathrm{CD}$ XII, 217. 
njegovih nasljednika 30 solida. To znači četiri libre mjesečno. ${ }^{121}$ Ta veza između Frankopana i senjskih franjevaca lako je prepoznatljiva u 15. stoljeću kada je loza frankopanska na vrhuncu svoje moći i ugleda i kada su odlučili da Senj bude središnje mjesto njihove prostrane "državine".

Sinovi Nikole Frankopana (+1432.) nastavili su frankopanski uspon u 15. stoljeću. Stjepan II. je na svoj Modruš doveo biskupa franjevca premjestivši njegovo sjedište iz Krbave i uz podršku pape utemeljio 1460. godine Modrušku biskupiju. Sigismund je iste godine dobio novu biskupiju u Otočcu, Martin je sagradio trsatski franjevački samostan i svetište. Dujam je podigao u Slunju novi franjevački samostan. Samostan u Cetinu također je frankopanska zadužbina, ali ne znamo kojemu od Frankopana treba za to najviše zahvaliti. I druga braća imala su znatne uspjehe. Na skupu u Brinju 1435. godine izabraše sinovi Nikole Frankopana senjsku franjevačku crkvu u Senju za mjesto gdje će se pokapati njihovi pokojnici. Ondje je vjerojatno pokopan i njihov otac Nikola (+1432.), a sigurno se zna da je ondje 1393. pokopan i djed Ivan. Ondje će biti pokopana 1456. godine supruga kneza Stjepana II., najmoćnijega od braće.

No, sve je to krenulo prema neuspjehu kada im je Matijaš Korvin 1469. godine oteo Senj. Bio je to udarac od kojega se frankopanski rod nije nikada oporavio. Pokušaji povratka u Senj sve ih je više iscrpljivao, a nije davao rezultate. Samo je više rasla netrpeljivost između njih i kraljevskog prijestolja. Kraljevi su se trudili da senjskoj Crkvi i senjskim franjevcima osiguraju potporu kakvu su prije dobivali od Frankopana. Nakon što im je kralj Matijaš oteo Senj, Frankopani nisu mogli tako izdašno pomagati franjevce. No, ipak su posebnu pažnju i dalje pokazivati senjskom samostanu, koristeći ga zacijelo i kao sredstvo za ostvarivanje svojih aspiracija na ponovno zadobivanje Senja. Knez Dujam i u tim okolnostima obdaruje 1487. godine franjevački samostan u Senju s 10 dukata godišnje. ${ }^{122}$

Kraljevi, počevši od Matijaša, smatrali su se obveznima da preuzmu ne samo frankopansko pravo nego i njihove obveze prema samostanu. Matijaš uzima u zaštitu senjske franjevce da mogu ubirati prihode od kuća u Senju, koje pravo su dobili od pape. ${ }^{123} \mathrm{U}$ to vrijeme $\mathrm{u}$ senjskom samostanu su observanti bosanske

${ }^{121}$ Darovnicu je objavio M. Sladović (1856, 237-238) pod datumom 12. kolovoza 1360. godine, a od njega je prepisao Smičiklas (CD XIII, 42-43). Poslije je Smičiklas ispravljeni datum i popravljeni tekst objavio pod nadnevkom 12. kolovoza 1365. godine (CD XIII, 456-457). Nakon Smičiklasovih popravaka, ima u tekstu dosta nejasnoća.

${ }^{122}$ Vjestnik, II (1900), 1, 45.

${ }^{123}$ M. SLADOVIĆ, 1856, 226-231; Vjestnik, II (1900), 1, 43 i 49. 
vikarije. ${ }^{124}$ Svoju zaštitu i potporu samostanu dali su i Matijaševi nasljednici. Vladislav 1505. godine uz to određuje da se od prihoda senjske mitnice daje samostanu godišnje 40 mletačkih denara, što su njegovi nasljednici Vladislav i Ludovik također potvrdili. ${ }^{25}$

U vrijeme uskočke krize (1537. - 1617.) i samostan je bio u materijalnoj krizi. Ona se produljila sve do oslobođenja od Turaka nakon Bečkog rata (1683. - 1699.). Tek u 18. stoljeću život je nekako došao u normalu što se odrazilo i na život samostana. Doduše, nema više onih darovnica kao što je bilo prije turske opasnosti, a sve ono što je tada darovano nije nakon oslobođenja od Turaka vraćeno. Što se tiče imanja, novi samostan unutar gradskih zidina koncem 18. stoljeća ne posjeduje ništa "izim vrtal kod zdenca na Travici (kasnije seminarski) i jednu senokošu imenom 'fratruša". ${ }^{126} \mathrm{Uz}$ to su, prema podacima iz 1770. godine, iznosili sumu od 3530 for. Drugi samostanski prihodi bili su sljedeći: prihod od mlina u Žrnovnici, 6 vinodolskih stara pšenice (darovnica kneza Nikole Frankopana iz 1632. godine), darovi od senjske mitnice itd. No, glavni prihodi samostana bili su od misa i milostinja. U tom smislu primjećuje Sladović: "...a ponajviše življahu od prošnje proseći pšenice i karišika, janjacah i masla po Lici do Gradčaca već od prvih vekovah, pšenice i smese po madruštini do Zira, janjacah u Podgorju, ječma i mošta po Vinodolu, a zelja po Krivom Putu (Krivih putih)." ${ }^{127}$ U prvim desetljećima 17. stoljeća bila su u samostanu dvojica ili trojica redovnika. Već u drugom dijelu stoljeća bilo ih je oko petnaest. Oko toga broja bilo ih je poslije do ukidanja samostana.

Iz dvadesetih godina 18. stoljeća sačuvan nam je prijepis dokumenata iz kojih se vidi koji su stalni izvori za njihovo uzdržavanje. ${ }^{128}$ Navest ću samo neke podatke koji mi se čine značajnijima. Juraj Daničić dao je 600 dukata za kapelu sv. Josipa i ujedno da se nabave orgulje koje nisu postojale. Ostavit će

${ }^{124}$ Godine 1514. samostan je pripadao cetinskoj kustodiji koja je imala svoje sjedište u samostanu svete Marije u Cetinu gdje je 1. siječnja 1527. godine izabran Ferdinand Habsburški za hrvatskog kralja. Od 1708. godine pa do odlaska franjevaca na Trsat, pripadali su hrvatskokranjskoj provinciji Sv. Križa (J. BURIĆ, 2002, 146).

${ }^{125}$ M. SLADOVIĆ, 1856, 228; Vjestnik, II (1900), 1, 46-47.

${ }^{126}$ Samostan ima samo vrt "penes puteum Travitza pro oleribus aliisque necessariis ad culinam, nin tamen sufficientibus, et unu foenile su inclyto Regimine Ogoliense, a quo aliquid de foeno pro necessitatibus conventus acquiritur" (BAS, fasc. III B, br. 7; M. SLADOVIĆ, 1856, 213). "Fratruša" koja se nalazi "in regimine Oguliense" je današnja Vrataruša na području Krivog Puta.

${ }^{127}$ M. SLADOVIĆ, 1856, 213.

${ }^{128}$ Zbirka dokumenata svakako potječe iz Senja. Sada se nalazi u Arhivu HAZU, I d, 93. Sve je pisano jednom rukom, što znači da je riječ o prijepisima. 
im oporučno s time da je njegova žena uživa do smrti. Odredio je također da ga pokopaju u franjevačkoj crkvi "kadi leži moj pokojni otac i moja pokojna mati". Njegova grobnica bila je u svetištu nedaleko samostanske kripte. Juraj Desantić ostavio je 1691. godine za kapelu sv. Josipa 600 dukata. Ivan Miovčić dao je 1701. godine kapeli ${ }^{129}$ sv. Antuna Padovanskog 1016 dukata. Napravio je podboj (?) u toj kapeli. Ivan Hreljanović dao je kuću i 600 dukata za izgradnju kapele Gospe Karmelske, a brat Vuk Hreljanović ostavio je za tu kapelu dio svoje kuće. Neki pojedinci držali su kod fratara svoje novce, a fratrima su davali od toga dogovorene kamate. Položeni novac je čuvan, ali i posuđivan uz kamate. ${ }^{130}$ Prihode su imali također, od kripta i grobnica u crkvi. Kripte su bile obzidani grob (grobište), a pokop (sepultura) jednostavna raka. Ako je na kripti bio natpis, za to je trebalo posebno dopuštenje i novčani dodatak.

$\mathrm{Na}$ popisu nisu navedene sve grobnice od kojih su nam se sačuvali nadgrobni natpisi. Navedena je kripta Karla Portnera "na livu ruku kod velikog oltara", grobnice Aichelberga, Petra Desantića, Ivana Čudinovića, Mihovila Radojevića, Antuna Rittera, Ivana Miočića (Miošića), Vinka i Vuka Hreljanović i još oko 70 pokojnika. Svako koji je želio biti pokopan dobio je pismo i platio je prema tome gdje je i u kakvu grobnicu je pokopan. Nakon nekog vremena gubi se pravo na grobnicu. Tako stoji da je grobnica gospodina Miletića slobodna i može se ukloniti ploča s natpisom. Ivan Bihaćanin kupio je grobnicu za sebe i za muške članove svoje obitelji dok ne promijene prezime (Bihaćanin). Na rijetkim grobnicama je natpis pa se u pismu kaže opisno (pokraj tog oltara, kod vrata, uz zid i sl.). Antun Portner ostavio je 1693. godine franjevcima svoj dio tunere u Lukovom (Otočkom). Uz darovnice često su vezane (legatae) obveze pa se službeno takav ugovor naziva legat. Redovno su za to franjevci trebali u određene dane služiti mise. Da bi se prihvatio jedan legat (obveza), trebalo je dopuštenje provincijalne uprave.

Prema iskazu od 28. ožujka 1770. godine bilo je u senjskom samostanu 13 redovnika-svećenika, 5 braće laika i jedan trećoredac, što je bilo dostatno za službu u Senju. Prema popisu u spomenutom sveščiću od 30. prosinca 1774. godine bilo je u Senju 13 svećenika i 5 braće laika. Tadanji i zadnji gvardijan samostana bio je o. Juvenal Smodin koji je ujedno vršio službu samostanskog knjižničara. Uz njega su bila dva redovnika - hrvatski propovjednik ("concionator Illyricus"), jedan njemački propovjednik ("concionator ad milites germanos"), jedan je bio

\footnotetext{
${ }^{129} \mathrm{U}$ ovim se spisima oltari u crkvi redovito nazivaju kapele.

${ }^{130}$ Tako npr. Ivo Tintor je 23. ožujka 1735. godine posudio od samostana 200 dukata (BAS, fasc. I B, br. 31).
} 
orguljaš i vodio pjevanje, jedan je bio magistar redovničkih klerika i nekojih biskupijskih klerika. Drugi su se opet bavili dušobrižništvom i ispovijedanjem u gradu, dok su nekoji od njih bili bez određene službe radi bolesti. ${ }^{131}$ Očito je da su sami radili sve kućne poslove te u vrtu i sjenokoši.

Međutim, opsežne reforme cara Josipa II. kojeg je pruski kralj Fridrih II. podrugljivo nazivao "sakristanom Sv. Rimske crkve" pogodile su i franjevački samostan u Senju. Da bi materijalno osigurao siromašno niže svećenstvo i u tu svrhu osigurao potrebna sredstva, dao je 1784. godine popisati dohotke visokog klera i ostalu crkvenu imovinu svjetovnog i redovničkog svećenstva. Za provedbu te osnove trebalo je vrlo mnogo novaca. Car ih je odlučio namaknuti tako da po primjeru isusovačkog reda (1773.) dokine sve muške i ženske redove (samostane) koji se nisu bavili njegovanjem bolesnika ili nastavom. To doista i izvrši te zaplijeni njihovu imovinu i tako osnuje vjerozakonsku i naukovanu zakladu. Tom prigodom bio je ukinut i franjevački samostan u Senju, a redovnici toga samostana prijeđoše u franjevački samostan na Trsatu koji nije došao pod udar carske reforme Josipa II. ${ }^{132}$ Franjevac o. Emanuel Hoško, profesor u Rijeci i na Trsatu piše ovako: Franjevci nisu napuštali Senj u najtežim vremenima uskočko-turskih i uskočko-mletačkih ratova 16. i 17. stoljeću. Prije franjevaca morali su napustiti Senj pavlini. Njihov je red dokinuo 1781. car Josip II. premda su u svom samostanu držali gimnaziju za senjske mladiće $i$ bogoslove senjskog biskupa. Franjevce je na početku mimoišla oštrica rušilačkih crkvenih reformi cara Josipa II. Samo su 1788. bili prisiljeni kroz pola godine ustupiti samostan za smještaj vojske. Senjski franjevci su se trebali preseliti na Trsat, ali je to neslužbeno odgođeno, a oni su se smjestili u privatnoj kući. ${ }^{153}$ Franjevci su još živjeli u nadi da će nakon odlaska vojske moći mirno nastaviti živjeti u samostanu pa 1789. godine preko senjskog biskupa upućuju molbu Ugarskom namjesničkom vijeću da mogu prodati samostansku srebrninu radi zamjene inventara u crkvi i samostanu jer je postojeći dotrajao. ${ }^{134}$ Preuzimaju 1791. godine vodstvo srednje škole u Senju. ${ }^{135}$ Vodili su senjsku gimnaziju samo 11 godina, a 1802. otkazali su daljnji rad zbog nedostatka profesora. Upravo je tada

${ }^{131}$ BAS, fasc. II B, br. 7; M. SLADOVIĆ, 1856, 212-213.

${ }_{132}$ P. TIJAN, 1940, 37.

${ }^{133}$ E. HOŠKO, 2014.; BAS, fasc. VI B, br. 17; BAS, fasc. IX B, br. 41. Franjevci su tada tražili dopuštenje da mogu prodati zavjetnu srebrninu kako bi mogli zamijeniti trošni inventar crkve i samostana. (BAS, fasc. VIII B, br. 5).

${ }^{134}$ BAS, fasc. VIII B, br. 5.

${ }^{135}$ BAS, fasc. IX, br. 29. Franjevci su i dalje smješteni u privatnoj kući jer je u samostanu bila vojska. (Usp. BAS, fasc. IX, br. 41) 
senjski biskup Ivan Krstitelj Ježić (1788. - 1833.) podnio prijedlog da se na prvom katu samostana senjskih franjevaca smjeste biskupijski sjemeništarci i profesori te osnuje bogoslovsku školu za njegovu biskupiju. Nakon niza molbi i predstavki, Ugarsko namjesničko vijeće odluči da se biskupu uvaži prijedlog. Franjevci su poduzeli sve da se ta odluka promijeni. Predlagali su biskupu da izabere za sjemenište bivši pavlinski samostan u Senju ili nekadašnji isusovački kolegij u Rijeci. To je sve, međutim, bilo bez uspjeha. Ostavili su Senj tek nakon ponovnih naredbi Ugarskoga namjesničkoga vijeća i nešto prije 13. srpnja 1806. godine napuštaju samostan s namjerom da u Senju opet podignu novu kuću. No, nije im uspjelo treći put doći u Senj.

Da se franjevci nisu lako pomirili s odlaskom iz Senja, vidi se po tome što još četiri godine jedan od trsatskih franjevaca nosi naslov "predstojnik samostana u Senju". Posljednji kome pripada taj naslov bio je 1810. godine o. Barlaam Keser, rodom iz Drage (1752.); postao je franjevac 1775., a u Senju ga susrećemo 1791. godine gdje vrši službu gimnazijskog profesora. Postao je 1802. godine poglavar senjskog samostana i s njim je upravljao sve do 1806 . godine. Tada je senjska franjevačka obitelj napustila Senj i preselila se na Trsat. Taj posljednji senjski franjevac postaje 1821. godine čuvar trsatskog svetišta i gvardijan samostana. Pomogao mu je njegov zamjenik o. Bernardin Salampić, rođeni Senjanin. Upravljao je trsatskom crkvom i samostanom samo tri godine, ali je tijekom tog vremena mnogo učinio - podigao novi zvonik trsatske bazilike, prekrio krov crkve i nabavio tri zvona. Umro je 21. rujna 1827. godine na Trsatu. ${ }^{136}$

Kada su senjski franjevci napustili svoj samostan u Senju, senjski biskup Ježić, budući da mu je uspjelo od kralja Franje I. ishoditi dozvolu za otvorenje sjemeništa od 24. studenoga 1804. godine, preuređuje bivši franjevački samostan za bogoslovno učilište Senjsko-modruške ili Krbavske biskupije. Sjemenište je svečano otvoreno 1. studenoga 1806. godine. ${ }^{137}$ Time prestaje višestoljetna prisutnost sinova sv. Franje u Senju. Ostavili su tako dubok pečat u gradu da se predaja o njima i njihovom rado prenosi od koljena do koljena, a i danas je ona prisutna. Katastarski se Travica vodila na franjevcima, odnosno na trsatskom samostanu kamo su se senjski franjevci odselili (iako franjevci nakon odlaska nisu taj prostor koristili). Koristili su ga Biskupija i Sjemenište. Kada je 2009. godine Gospićko-senjska biskupija dopustila Gradu Senju gradnju doma umirovljenika na tom prostoru, 4. ožujka 2009. godine trsatski gvardijan Lucije Jagec izdao

\footnotetext{
${ }^{136}$ E. HOŠKO, 1974, br. 3, 3-4.

${ }^{137}$ M. SLADOVIĆ, 1856, 290.
} 
je tabularnu ispravu kojom se Travica prenosi u vlasništvo Gospićko-senjske biskupije ${ }^{138}$, koja je 2000. godine osnovana i naslijedila time imovinu Senjskomodruške ili Krbavske biskupije na svom području.

\section{Franjevački samostan i crkva sv. Franje u Senju}

\section{Crkva i samostan "izvan gradskih zidina"}

Kako je prije spomenuto, nema sumnje da je franjevački red postojao u Senju još 1272. godine, tj. svega 40-ak godina nakon dolaska franjevaca u Hrvatsku. Prvi pisani trag franjevačke prisutnosti u Senju potječe iz spomenute 1272. godine. Tada neki Jakov, sin Ivankov iz Senja, ostavlja maloj braći u Senju dva svoja vrta koja se nalaze kod franjevačke crkve, kraj zdenca i javnog puta. ${ }^{139}$ Franjevci, dakle, tada već imaju crkvu u Senju. Postojanje te crkve siguran je dokaz za prisutnost franjevaca u Senju.

Drugo što se tu nameće kao očito jest da je dolazak franjevaca vezan uz dolazak Krčkih knezova za gospodare Senja, nakon templara. Poslije se ispostavilo da su knezovi franjevcima sagradili crkvu i samostan. Svakako, dvadeset godina kasnije (18. travnja 1292. godine) imaju franjevci u Senju svoj samostan (locus) s gvardijanom. ${ }^{140}$ Sljedeće godine spominje se u Senju izričito samostan franjevaca male braće. ${ }^{141}$ Dakle, 1272. godine spominje se franjevačka crkva, a 20 godina kasnije i samostan. Da se u oba slučaja radi o istoj lokaciji, vidimo iz darovnice od 10. studenoga 1295. godine kada knez Ugrin, uz suglasnost Krčkih knezova Leonarda i njegova sinovca Bartola, daruje franjevcima vrt u blizini velikog zdenca i javnog puta ${ }^{142}$, kako je to rečeno i 1272. godine.

Imamo, dakle, već crkvu i samostan franjevaca kraj (velikog) zdenca i nedaleko kuća Krčkih knezova. No, 1. lipnja 1298. godine zbiva se posveta franjevačke crkve. Posvetio ju je korčulanski biskup Petar koji je ujedno podijelio oprost od godine dana svima onima koji budu na godišnjicu posvećenja ili sedam

${ }^{138}$ Biskupski arhiv Gospić, Spisi 2009., br. 71. Jedno vrijeme poslije Drugog svjetskog rata koristile su Travicu sestre Presvetog Srca Isusova.

${ }^{139} \mathrm{CD}$ V, 622, Jakov Ivankov daruje franjevcima "duos ortos meos positos Segnie apud ecclesiam et ortum ipsorum fratrum et apud puteum et viam publicam" (usp. BAS, kutija I K, br. 1), što znači da su franjevci već bili u Senju i imali ondje crkv, a onda i neki samostan.

140 "de consilio g(u)ardiani fratrum isti loci" (CD, VII, 81).

141 "conventus fratrum minorum" (CD, VII, 157).

142 "prope puteum magnum et prope locum fratrum minorum de Segnia" (CD VII, 212). Gotovo ista formulacija kao i u darovnici iz 1272. godine. Samo ovdje se ne spominje crkva, nego samostan (locus). 


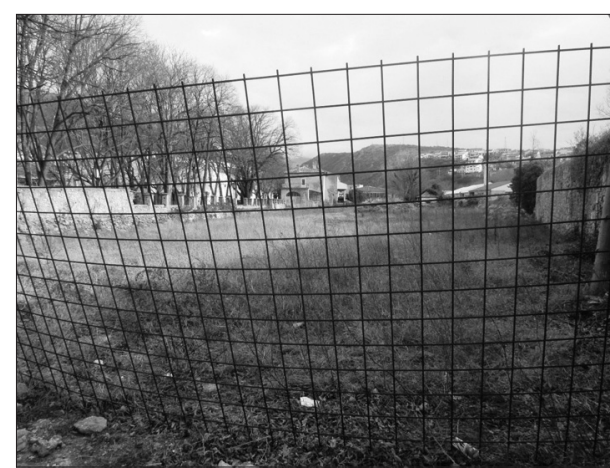

S1. 21. Građevinski radovi na pretpostavljenoj lokaciji crkve i samostana franjevaca izvan zidina, 18. siječnja 2020. (foto: B. Ljubović)

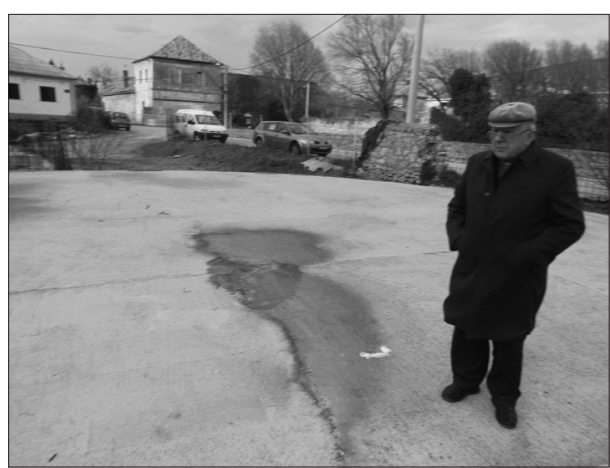

S1. 22. M. Bogović u obilasku lokaliteta Travica, 18. siječnja 2020.

(foto: B. Ljubović)

sljedećih dana pohodili istu crkvu. ${ }^{143}$ Po svemu sudeći, radi se o novoj crkvi. Franjevci su prema tome najprije sagradili (ili dobili) manju crkvu koja postoji još 1272. godine, a nakon toga pristupili su izgradnji samostana kraj crkve koji postoji 1292. godine. Kad je samostan bio dovršen, pristupili su izgradnji nove i veće crkve. To će biti ta crkva koja je posvećena 1. lipnja 1298. godine.

Tako smo dobili i samostan i crkvu koja će se održati sve do četrdesetih godina 16. stoljeća. O toj crkvi i samostanu govore Frankopani u 15. stoljeću da su je njihovi preci sagradili i bogato nadarili i ukrasili. Franjo Glavinić je zapisao u svojoj povijesti Provincije Bosne Hrvatske da je crkva sagrađena 1297. godine. ${ }^{144}$ Od njega su to preuzeli Vitezović ${ }^{145}$ i Farlati ${ }^{146}$, a poslije i drugi povjesničari.

143 "intenditis ecclesiam quam habetis in civitate Segna facere consecrari" (CD, VII 303). Senj je tada imao svoga biskupa Nikolu. Vjerojatno je korčulanski biskup imao posebnu povlasticu posvećivati franjevačke crkve i obdariti ih oprostima. Zato je crkvu on posvetio.

144 "La Chiesa et il Monastero di Segna in Dalmatia ... fù edificata ad honor di San Francesco da due fratelli conti Frangepani, come appare nelli nostri antichi Annali, cioè Leonardo e Duimo l'anno 1297, fuori delle mura della Città verso oriente, ove anco hoggidi si vedono vestigij. ... Ma dopo la perduta de' Contadi di Licha e Corbauia, fù per timor dell'incurssioni de' Martolosi transportato entro la Città l'anno 1560." (F. GLAVINICH, 1648, 27). Prostor se, dakako, u Glavinićevo vrijeme nalazio izvan zidina Senja, ali u vrijeme gradnje taj prostor uvijek se smatrao u sastavu samoga grada. Glavinić se i ovdje pokazao neprecizan u godinama.

145 "1297. Linard y Dujam Knezi Frangepani zidasse Klostar S. Ferenca pri Szenyu, koga pak Lenkovich porussi" (P. RITTER VITEZOVIĆ, 1696, 97).

${ }^{146}$ D. FARLATI, 1769, 120. 
Iz svega onoga što je gore rečeno, godina 1297. može se odnositi samo na crkvu, ali se može prihvatiti da su iza cijelog projekta izgradnje crkve i samostana stajali Krčki knezovi (iako se to izričito ne kaže u suvremenim izvorima).

Još nitko nije odgonetnuo točnu poziciju, odnosno lokaciju samostana i crkve, a kamoli da bi se mogla otkriti njezina veličina $i$ arhitektura. U prosvjednom pismu knezova Frankopana kralju Ferdinandu u rujnu 1540. godine, knezovi kažu da su njihovi preci sagradili "glasoviti hram" (famosissimum templum) ${ }^{147}$, što kaže dosta i o arhitekturi te crkve. Znademo da su u crkvi bile grobnice nekih Krčkih knezova, poslije prozvanih Frankopanima te da su u crkvi imali svoje grobnice i neki senjski građani. Od drugih pojedinosti znamo za glavni oltar posvećen sv. Franji i za tri pokrajnja: Majke Božje ${ }^{148}$, sv. Marka ${ }^{149}$ i sv. Jurja. ${ }^{150}$ Iz onoga što nam je poznato ipak možemo odrediti širi prostor na kojemu su se nalazili crkva i samostan. To je prostor današnje Travice. ${ }^{151}$

${ }^{147}$ E. LASZOVSKI, MH III ,11. Neki misle da je pročelje nove crkve u gradu građeno od kamena stare crkve. Ako je tako, onda je crkva bila doista solidno građena.

${ }^{148}$ Dana 21. lipnja 1345. godine dozvoljava se Beneventu, bivšem sucu, i njegovoj ženi podignuti žrtvenik Majci Božjoj i pred tim oltarom napraviti sebi grobnicu "in ipsorum fratrum ecclesia, in civitate Segnie posita" (CD XI, 203-204).

${ }^{149}$ CD XIII 482.

${ }^{150}$ ASV, Reg. Vat., vol. 599, f. 226v-227r. Zanimljivo je da je i u susjednoj crkvi sv. Petra postojao oltar sv. Jurja. Godine 1401. spominje se Andrija Jelmenh kao rektor oltara sv. Jurja u crkvi sv. Petra, izvan gradskih zidina.(Monumenta vaticana historiam regni Hungariae illustrantia, I/IV, 1896, 324). Ta bi činjenica nekako išla na ruku onima koji kažu da je crkva sv. Petra bila franjevačka, odnosno samostanska crkva. Ipak treba uzeti u obzir da je oltar sv. Jurja u crkvi sv. Franje dao sagraditi Stjepan Frankopan, a on to nije mogao učiniti 1401. godine jer se tada još nije ni rodio. Prema tome nema ozbiljnih razloga za tvrdnju da je crkva sv. Petra bila franjevačka samostanska crkva.

${ }^{151}$ Taj prostor senjski franjevci su koristili i nakon što su dobili crkvu i samostan u gradu. U izvješću gvardijana senjskog franjevačkog samostana 30. prosinca 1774. godine stoji da samostan ima svoj vrt kraj zdenca Travica ("penes puteum Tracitza") za ulje i druge kuhinjske potrepštine (BAS, fasc. III B, br. 7). Vlasnik toga prostora sve do nedavno bio je trsatski franjevački samostan kao nasljednik vlasničkih prava senjskog samostana nakon što su franjevci otišli 1807. godine iz Senja na Trsat. Kada se na Travici krenulo 2009. godine u izgradnju doma za starije i nemoćne u Senju, trsatski samostan prenio je vlasništvo na Gospićko-senjsku biskupiju (Biskupski arhiv Gospić, Spisi 2009., br. 71), a Biskupija je onda sklopila ugovor o gradnji s Gradom Senjom, s time da se ne mijenja vlasnik. Grad je započeo gradnju bez potrebnih arheoloških izvida, tako da se tragovi samostana i crkve više ne može ni tražiti od sile betona kojim je ispunjen cijeli prostor. I "Veliki zdenac" je zagušen betonom. Gradnja je obustavljena zbog nedostatka sredstava, ali prostor je učinjen neiskoristivim za bilo koju namjenu, osim za gradnju. Grad je 2019. godine otkupio cijeli prostor Travice i preuzeo vlasništvo nad njim. 


\section{I samostan i crkva bili su na Travici}

Već je spomenuto kako 1272. godine neki Jakov, sin Ivankov iz Senja, ostavlja maloj braći u Senju dva svoja vrta. On dosta precizno naznačuje gdje se ti njegovi vrtovi nalaze: nalaze se kraj franjevačke crkve i franjevačkog vrta, a to je sve nedaleko velikog bunara i uz javni put. ${ }^{152}$ To znači da je crkva sv. Franje u blizini velikog bunara. Znamo da je jedan bunar bio na današnjoj Cilnici gdje je u 19. stoljeću podignuta fontana. Taj ne može doći u obzir jer nije bio nikada "izvan zidina", kao što je bio franjevački samostan. Veliki bunar nalazi se i danas na Travici (samo je sada zatrpan smećem i betonom!). Mislim da bi na tom prostoru trebalo tražiti lokaciju crkva i samostana sv. Franje. Izraz "javni put" ne daje nam mnogo podataka jer je javnih putova u Senju bilo dosta. No, ako se uzme da je "veliki bunar" utvrđena točka, onda se može naslutiti kuda bi išao taj javni put. Koristan podatak imamo iz 1319. godine gdje se govori o nekom komadu zemlje uz "javni put" koji vodi prema mjestu manje braće (locum fratrum minorum). ${ }^{153}$

Gdje su se nalazili crkva i samostan dosta kaže i darovnica koju su braća Frankopani izdali u Brinju 1435. godine. Tu se kaže da su samostan i crkva "izvan i blizu zidina grada Senja". ${ }^{154}$ Prije 15. stoljeća svi poznati dokumenti tu crkvu nazivaju crkvom sv. Franje ${ }^{155}$ i da se ona nalazi u gradu Senju (in civitate Segniae). Od početka 15. stoljeća pa dalje govori se da je samostan s crkvom od početka bio izvan gradskih zidina (extra muros civitatis). Da bismo riješili prividnu proturječnost valja prije reći nešto o nastanku senjskog kaštela i zidina oko grada. Prije 1400. godine nisu poznati izrazi "unutar zidina" ili "izvan zidina". Tek kada zidine opašu Senj sa svih strana, postat će jasno što se nalazi izvan zidina, a što je unutra. Obično se misli da su Krčki knezovi počeli s gradnjom kaštela. Kaštel, čini se, 1292. godine još ne postoji jer se govori da su tada u Senju kuće Krčkoga kneza Leonarda. ${ }^{156}$ Te kuće su Krčki knezovi zacijelo naslijedili

152 Jakov Ivankov daruje franjevcima "duos ortos meos positos Segnie apud ecclesiam et ortum ipsorum fratrum et apud puteum et viam publicam". (CD V, 622)

${ }^{153}$ Dana 1. studenoga 1319. godine prodaje se komad zemlje u Senju "positam in civitate Segnie prope domum Petrich generis Curti et prope domum Georgii nepotis Malouig et viam publicam qua itur ad locum fratrum minorum". (CD VIII, 544-545)

${ }^{154} \mathrm{Tu}$ se kaže da su njihovi preci sagradili samostan i crkvu "extra et prope moenia civitatiss nostrae Segniae". (M. SLADOVIĆ, 1856, 241.)

${ }^{155}$ Usp. M. BOGOVIĆ, 1988, 21.

156 Jedna kuća darovana franjevcima 18. travnja 1292. godine nalazi se kod kuća kneza Leonarda ("apud domos comitis Leonardi") (CD VII, 81). Po svoj prilici je kod tih kuća ili na njihovom mjestu sagrađen poslije kaštel. 
od templara. Za templare je bilo potrebno imati na raspolaganju širi prostor $u$ Senju. To nije moglo biti u samom središtu grada, nego na njegovoj periferiji, ali u sastavu grada. Najizglednije je ta periferija bila na prostoru današnjeg kaštela, odnosno ondje gdje 1292. godine nalazimo nasljednike templara, Krčke knezove. Ne samo da su te kneževe kuće tada u granicama grada Senja, nego i kuće (i crkve?) sjeverno od njih pripadaju gradu. To se zacijelo može reći za područje današnje Travice i veći dio današnje Aleje, a možda i cijela Aleja. I one su se do 15. stoljeća vodile da su u gradu (in civitate). Tek kada je krajem 14. stoljeća povučen zid oko cijeloga grada, a kaštel koji je u međuvremenu sagrađen, postao glavna utvrda u tom zidu, tada se javlja izraz "izvan zidina" (extra muros) za područje sjeverno od kaštela. Tako se moglo dogoditi da se franjevački samostan nalazio do kraja 14. stoljeća u gradu (in civitate), a da se u 15. stoljeću za taj isti prostor govori da je izvan gradskih zidina (extra muros) iako se nalazio stalno na istom mjestu. Knez Dujam u svojoj darovnici od 14. rujna 1481. godine navodi da je samostan blizu gradskih zidina (prope muros civitatis). ${ }^{157} \mathrm{U}$ to vrijeme zidine su već opasivale cijeli Senj. Zidine su bile izgrađene najprije prema moru. Grad na moru teško je mogao opstati bez zidne zaštite zbog opasnosti od gusara. Valja znati da su Mlečani 1380. godine zapalili Senj, a već se tada osjećala opasnost i s kopnene strane. Trebalo je osigurati grad sa svih strana.

Treba, dakle, o tome voditi računa u traženju mjesta franjevačkog samostana i crkve jer se obično govori i piše da je franjevački samostan s crkvom sv. Franje bio od početka izvan zidina, a izvori jasno kažu da su samostan i crkva u gradu (in civitate). U vrijeme kada su samostan i crkva srušeni, tada je već bio podignut zid na crti gdje je on i danas i zato se u vrijeme rušenja govori o tim građevinama da su izvan gradskih zidina. Bilo je to 1540. godine ili nešto prije, kada su, zbog opasnosti da ne bi kuće pred zidinama Turcima poslužile kao zaklon u eventualnom napadu na Senj, porušene sve građevine koje su se tada našle izvan zidina (nakon što su te zidine napravljene). Ovo tumačenje pomiruje starija svjedočanstva da su franjevački samostan i crkva sv. Franje bili "u gradu" i kasnija svjedočanstva da su bili "izvan gradskih zidina". U prilog takvog shvaćanja ide do sada najstarija vijest o franjevcima u Senju iz 1272. godine prema kojoj se njihova crkva nalazi blizu velikog bunara (prope puteum magnum). Taj bunar se, kako je prije spomenuto, i danas nalazi na Travici. Stariji ljudi se još sjećaju toga bunara na Travici. ${ }^{158}$ Danas je on zatrpan otpadom i prekriven betonom. Ipak, i to tumačenje ima svojih slabosti jer neki stariji izvori

${ }^{157}$ D. FARLATI, 1769, 120; M. SLADOVIĆ, 1856, 243.

${ }^{158}$ Vrt koji su franjevci dobili nalazi se "positum ac situm prope puteum magnum ac prope locum fratrum minorum de Segnia". (CD VII, 212-213). 
govore da je crkva sv. Franje u središtu grada. Tako 12. srpnja 1339. godine u darovnici Tumpe, Draškovog sina, od plemena Vukovića iz Gacke, stoji da je on sagradio crkvu Majke Božje u Senju blizu crkve manje braće (franjevaca). ${ }^{159}$ Nije poznato da je postojala neka crkva Majke Božje na Travici, a znade se da je bilo crkava Majke Božje blizu današnjeg mjesta crkve sv. Franje. Jedna od njih je i ona koja je bila iza svetišta današnje katedrale. To bi išlo u prilog mišljenju onih koji kažu da su franjevci i pored crkve sv. Franje i samostana na Travici imali i u središtu grada neki sakralni prostor i kuću (samostan).

Znade se stavljati prijašnji samostan i crkva na prostor sv. Petra, gdje je bila crkva posvećena istoimenom svecu. Do zabune je došlo iz toga što je nakon što je Senj opasan zidinama uspostavljena nova župa, a možda i prije, za sve one koji su ostali izvana. Središte te vanjske župe bilo je u crkvi sv. Petra. Za to područje govori se u dokumentu iz 17. travnja 1401. godine kao o vanjskoj župi, tj. o župi svih vjernika kraj Senja koji su se našli izvan zidina. ${ }^{160}$ Ona, dakle, pripada biskupijskim pastoralnim strukturama, a ne redovničkim, odnosno franjevačkim. ${ }^{161}$ Prostor sv. Petra znači zapravo područje župe Sv. Petar, a ta je župa obuhvaćala sva naselje koje su se tada nalazila izvan zidina. U tom smislu treba shvatiti i Vitezovićeve riječi: "1558. ... Fortecza ali gornya Tverdyava Szenyszka, bê gradyena od Lenkovicha Generala, kapitana Szenyskoga, ki csini porussit vse klostre, Cirque $i$ ves vunyski varos, od straha Turskoga". ${ }^{162}$ Sve je to porušeno bilo na području (plovanije/plebanije) sv. Petra. Doista se samostan sv. Franje nalazio na prostoru župe sv. Petra. Taj podatak nam je važan i zato što se tu prvi put spominje izraz "izvan zidina", što znači da su već tada izgrađene zidine i sa sjeverne strane i da se za prostor crkve i samostana sv. Franje kaže da je "izvan zidina". Izričito ćemo to naći 12. siječnja 1435. godine u darovnici braće Frankopana senjskim franjevcima gdje oni obdaruju crkvu i samostan koji se nalaze "izvan i blizu zidina našega grada Senja". ${ }^{163}$ Već tada je, dakle, prostor crkve sv. Franje bio izvan zidina, ali ne daleko od njih, što upućuje na prostor današnje Travice. U toj darovnici prvi put se susrećemo i s imenom Frankopani za Krčke knezove.

159 "prope ecclesiam loci fratrum minorum de Segnia" (CD X, 474-476).

${ }^{160}$ Dana 17. travnja 1401. godine Andrija Jelcomh je "upravitelj oltara sv. Janje u crkvi sv. Petra koja se nalazi izvan senjskih zidina" (rector "altaris S. Agnetis, sine cura, in ecclesia S. Petri extra muros signienses sita") (Mon. Vat. Hungariae I/IV, 324, bilj. A, 17)

${ }^{161}$ Nije jasno otkuda je Valvasoru (1689.) podatak da je ondje bila ženska redovnička zajednica (J. W. de VALVASOR, IV, 1689, 75).

${ }^{162}$ P. RITTER VITEZOVIĆ, 1696, 150-151. (Usp. A. GLAVIČIĆ, 1965, 321, bilj. 1)

163 "positos extra et prope moenia civitatis nostre segnie" (E. SLADOVIĆ, 1856, 341). 
Postoji, dakle, crkva sv. Petra, ali ona se ne smije poistovjetiti s franjevačkom crkvom koja je nedvojbeno posvećena sv. Franji. No, ta franjevačka crkva nalazila se u 15. stoljeću na području "vanjske župe" (pučke, za puk, plebanije ili plovanije) kojoj je središte crkva sv. Petra. Imamo, dakle u to vrijeme gradsku župu s katedralom i plovaniju (pučku župu) s crkvom sv. Petra. Crkva i samostan sv. Franje nalazili su se na području župe sv. Petra, kao što se na tom području nalazila i crkva sv. Jurja, kako je gore rečeno. Ako je toj župi pripadalo sve izvan zidina, onda su tu: današnji prostor Aleje, Trbušnjak, Mundarićevac i drugi naseljeni prostori oko Senja. Što je više rasla turska opasnost, to je ta župa bila prostorno šira, možda je uključivala Sv. Križ i Sv. Juraj, ali je slabila u broju vjernika.

\section{Frankopani izabiru Senj za središte svoje "državine"}

Poznato nam je da je dolazak Krčkih knezova u Senj vezan uz odlazak njegovih prethodnih vlasnika - templara. Naime, 1269. godine odlaze iz Senja dotadašnji njegovi gospodari templari, a grad dobivaju Krčki knezovi. Templari su bili vojnici, ali su bili i redovnička zajednica pa se s pravom pretpostavlja da su franjevci naslijedili njihove sakralne građevine, dok su one vojnog i civilnog karaktera preuzeli novi vlasnici Krčki knezovi. O tome svjedoči i Vitezović kada kaže: "1297. Linard i Dujam knezi Frangepani zidasse Klostar s. Ferenca pri Szenyu koga pak Lenkovich porussi."164 Vitezović se oslanja na pisanje Franje Glavinića. Takvo je uvjerenje, s obzirom na gradnju samostana, bilo u 17. stoljeću, ali do 15. stoljeća izvori nam izričito ne potvrđuju da su franjevačka crkva u Senju i samostan zadužbina Krčkih knezova. Ipak se i iz starih izvora može naslutiti određena povezanost te obitelji s franjevcima u Senju.

Kako je kaštel bio sagrađen kao njihovo obitavalište i glavna utvrda u Senju, crkva i franjevački samostan mogli su knezovima poslužiti i kao mjesto za pokapanje pokojnika. Prije 15. stoljeća poznat nam je samo jedan slučaj da je netko od Krčkih knezova pokopan u franjevačkoj crkvi u Senju. To je knez Ivan V., otac kneza Nikole IV. koji se prvi nazvao Frankopan. Ivan je umro u Senju 29. studenoga 1393. godine i pokopan je u franjevačkoj crkvi 1. prosinca. ${ }^{165}$ Iz te crkve sačuvala nam se samo jedna frankopanska ploča, ona Ižote d'Este $(+1456$.), supruge Stjepana II. Frankopana, koja je sredinom 16. stoljeća prenesena u novu crkvu unutar zidina. Je li još neki frankopanski spomenik prenesen i - ako je gdje se on nalazi?

\footnotetext{
${ }^{164}$ P. RITTER VITEZOVIĆ, 1696, 97.

${ }^{165}$ F. RAČKI, 1868, 147.
} 
Za Nikolu IV., koji se prvi potpisuje Frankopan, zna se točno da je umro 26. lipnja 1432. godine, ali nigdje ne piše gdje je umro i gdje je pokopan. U senjskoj crkvi sv. Franje, izvan zidina, bio je frankopanski grb koji je poslije prenesen i stavljen na pročelje crkve sv. Franje sagrađene unutar zidina. Na tom grbu je zvijezda iz staroga grba, ali se prvi put javljaju i lavovi koji lome kruh (frangunt panem - frangipani), od čega dolazi naš naziv - Frankopani. Dakle, u staroj crkvi sv. Franje u Senju nalazio se novi frankopanski grb. Franjevcima te crkve dali su sinovi Nikole IV. Frankopana donaciju uz obvezu da se povodom obljetnice smrti njihovog djeda i oca misi zadušnica za njihove duše.

Imamo siguran podatak da je Nikolin otac, Ivan V., pokopan 1. prosinca 1393. godine u franjevačkoj crkvi u Senju. ${ }^{166}$ Čini se da na temelju toga možemo pretpostaviti da je tu pokopan i njegov sin Nikola IV. Na tom frankopanskom grbu nalazimo kraj grbonoša (anđela) i dva redovnika. Nema sumnje da su to franjevac i pavlin. Naime, za sv. Pavla pustinjaka, kojega pavlini smatraju svojim utemeljiteljem, znamo da ga se prikazuje sa stablom na osami (u pustinji). Ovdje desni redovnik drži u ruci grančicu koja simbolizira stablo. Kada se zna da je Nikola IV. najviše pomagao franjevce i pavline (Crikvenica, 1412.) ${ }^{167}$, nije prenategnuto razmišljanje da $\mathrm{i}$ ta kombinacija redovnika franjevca i pavlina ukazuje na Nikolu IV. Frankopana.

Frankopanskim grbom na pročelju franjevačke crkve u Senju bavili su se u novije vrijeme Zorislav Horvat i Predrag Marković. Horvat smatra (prihvaćajući mišljenje Dijane Vukičević Samardžija) da frankopanski grb na pročelju crkve pripada Nikolinom sinu Ivanu VI. Frankopanu koji je umro 1436. godine. ${ }^{168}$ Predrag Marković smatra pak da je taj grb dio sarkofaga Nikole IV. Frankopana, oca Ivana VI., odnosno da "možemo s velikom vjerojatnošću pretpostaviti kako je veliki grb s anđelima flankiran franjevačkim svecima ukrašavao upravo njegov nekoliko godina ranije nastao nadgrobni spomenik". Kamena ploča na pročelju, na kojoj su reljefno prikazani Isus te sa strane Petar i Pavao pa franjevački sveci, prema Markoviću, predstavlja bočnu stranu toga Nikolinog sarkofaga. No, Marković je prepoznao na fasadi ostatke ne jednog, već dvaju sarkofaga. Dio drugog sarkofaga s likovima Navještenja te sv. Jurja i sv. Katarine, pripada nešto mlađem sarkofagu za koji on smatra da pripada Nikolinom sinu Ivanu VI. koji je umro 1436. godine. ${ }^{169}$ Kako je poznato da je

${ }^{166}$ F. RAČKI, 1868, 147.

${ }^{167}$ Usp. M. MATIJEVIĆ SOKOL - T. GALOVIĆ - I. BOTICA, 2008.

${ }^{168}$ Z. HORVAT, 2005, 30.

${ }^{169}$ P. MARKOVIĆ, 2006. 14. Juraj Lokmer je sklon mišljenju da je grb djelo kipara Marka Senjanina (J. LOKMER, 2015-2016, 276, bilj. 282). 
u Mađarskoj nađena njegova nadgrobna ploča s grbom, Marković smatra da prva narudžba nije realizirana pa je uslijedila druga koju vidimo na pročelju crkve sv. Franje u Senju. ${ }^{170}$

Teško se suprotstaviti mišljenju povjesničara umjetnosti koji dobro uočavaju forme likovne stilizacije pa spomeniku po tome mogu odrediti vrijeme nastanka, ali kao povjesničar sklon sam dio drugog sarkofaga vezati ne uz Nikolina sina Ivana VI. (+1436.), već uz njegova oca Ivana V., za kojega se sigurno zna da je umro u Senju 30. studenoga 1393. godine i pokopan 1. prosinca upravo u franjevačkoj crkvi iste godine. Imajući u vidu ugled i uloge koje je imao u svojem životu, izgleda nevjerojatno da ne bi imao neki izgledniji spomenik. Tom Ivanovom spomeniku iz 1393. godine sklon sam pripisati i bočnu ploču sarkofaga s franjevačkim svecima jer je velika razlika između nje i grba Nikole IV. Frankopana (+1432.). Za njegova unuka Ivana VI. koji je umro 1436. godine nađena je nadgrobna ploča u Mađarskoj s njegovim imenom i prezimenom i datumom smrti pa je manja vjerojatnost da je pokopan u Senju. ${ }^{171}$ I pored toga što sam pod dojmom Markovićeve vrsne stručne analize ostatka sarkofaga, čelni dio sarkofaga s likovima Navještenja zajedno $s$ bočnom pločom sarkofaga na kojoj je Isus s franjevačkim svecima usudio bih se smjestiti četrdesetak godina unatrag, tj. do smrti kneza Ivana V. 1393. godine.

Dvadesetih godina 15. stoljeća, kada je već njihovo područje na kopnu višestruko veće nego ono na Krku, događa se i nominalno odvajanje Krčkih knezova od svog otoka Krka. Oni su dobili svoje zajedničko prezime Frankopan (Frangipani). U skladu s tadašnjim humanističko-renesansnim mišljenjem da najviše plemstvo ima svoje korijene u Rimu, zatražio je i moćni Nikola IV. od pape da mu to potvrdi. Tu potvrdu je dobio dvadesetih godina 15 . stoljeća. ${ }^{172}$

${ }^{170}$ P. MARKOVIĆ, 2006, 22.

${ }^{171} \mathrm{Na}$ grobnoj ploči piše: "Hic est sepultus magnificus dominus Johan(n)es goph de Frangepanibus Segnie Veglie Modrussieq(ue) comes qui obiit XX die mensis novembris anno domini MCCCCXXXVI. Requiescat in pace". (Z. HORVAT, 2005, 31)

${ }_{172}$ Nikola IV. Frankopan poslao je 1422. godine poslanstvo u Rim na čelu s Tomom Ladihovićem Jurjevim. S njime je bio i Ivan Pavlov, rodom iz Krka, pravni stručnjak (decretorum doctor), svećenik Senjske biskupije. Papa Martin V. izdaje im 13. siječnja 1422. godine garantno (salvum conductum) pismo da mogu putovati sa svojom prtljagom, knjigama i ostalim što im pripada, bez plaćanja putarine i carine (ASV, Reg. Vat., vol. 353, f. 298v). Po svoj prilici papa je tada Nikoli IV. i njegovom rodu potvrdio porijeklo od rimskih Frankopana. Taj naziv susrećemo u Nikolinoj darovnici u korist Senjskog kaptola od 6. prosinca 1426. godine. (D. FARLATI, 1769, 125; M. SLADOVIĆ, 1856, 187-189). No, knez Nikola IV. (poslije 1352. - 1432.) po prvi se put 1422. godine počinje navoditi kao Frangipan, tj. Frankapan (magnifici viri domini Nicolai de Frangiapanibus, Vegle et Modrussie etc. comitis). Usp. L. ŠPOLJARIĆ, 2015-2016, 3-40. 
Tada se jače osjetila potreba središta njihova vladanja, ili kako neki kažu, "njihove državine". Kao da je to novo središte već osjetio i Nikolin otac Ivan V. koji je upravo u Senju pokopan. Nikola IV. je bio još svjesniji od oca Ivana V. da je njegov rod nadrastao krčke okvire i da Frankopani trebaju imati središte na hrvatskom kopnu. Sva je prilika da je njegov izbor bio na Senju. Nije, dakako, Nikola IV. izabrao Senj samo zbog obiteljske zadužbine - franjevačke crkve nedaleko kaštela. Sâm Senj mu se svojim položajem i ugledom nametnuo. Uostalom, bio je staro biskupsko središte, pa se samo po sebi nudi i kao središte frankopanske državine.

Još prije nego je obdario senjske franjevce, obdario je on velikodušno crkvu i kaptol u Senju. Odredio je 1426. godine da se kanonicima i prebendarima senjske crkve daje svake godine 60 zlatnika, za što su oni bili dužni svaki dan pjevati u zoru jednu misu na čast Majke Božje za njega i za njegove pokojne. Tu obvezu on je prenio i na svoje potomke. ${ }^{173}$ Potrebu jednog središta osjetio je tim više što je imao mnogo djece i lako je bilo predvidjeti da će se sinovi međusobno razgraničiti pa je potrebno nešto učiniti da baštinjeno ne izgubi svoju cjelinu i povezanost. Drugi korak učinili su njegovi sinovi devet godina poslije kada im je otac već umro (1432.), na sastanku u Brinju 12. siječnja 1435. godine. ${ }^{174} \mathrm{Na}$ početku same darovnice ističu da to čine posebno sjećajući se svojih predaka koji su crkvu i samostan sv. Franje sagradili i dotirali mnogim dobrima i godišnjim prihodima. U tu svrhu sporazumno daruju rečenom samostanu sv. Franje u Senju za sva vremena i neopozivo svoje mlinove u selu Vilići kod Otočca sa svima vodama i ostalim što im pripada. Redovnici rečenog samostana i njihovi poglavari primiše sa zahvalnošću donaciju spomenutih knezova Frankopana uz sljedeće obveze:

1) da će u samostanu imati stalno deset redovnika-misnika, kao i odgovarajući broj klerika i slugu za službu rečenim svećenicima;

2) da će svaki od njih služiti dvije mise, jednu pjevanu za njihove pokojne, a drugu za živuće članove njihove obitelji;

3) da će samostan svake godine vršiti službu za njihovog pok. djeda te pok. oca i majku prema običaju, kao i za spomenute knezove i njihove žene po njihovoj smrti;

${ }^{173}$ M. SLADOVIĆ, 1856, 187-189.

174 "reccolendae memoriae progenitorum nostrorum qui ecclesiam et conventum b. Francisci ordinis minorum positos et situates extra et prope moenia civitatis nostrae Segniae aedificarunt et construxerunt et successive multis utilitatis et annuis reditibus dotaverunt." (M. SLADOVIĆ, 1856, 241-243; V. KLAIĆ, 1991, 222; Prijepis darovnica u Kaptolskom arhivu u Senju). 
4) u slučaju da netko od njih bilo njihovih obitelji umre izvan Senja, ali u granicama njihova vladanja ili u banovini, redovnici će doći na mjesto smrti dotičnoga člana frankopanske obitelji i dopratiti ga do Senja. ${ }^{175}$

Stjepan II. Frankopan sagradio je 1448. godine u franjevačkoj crkvi kapelu i oltar sv. Jurja. ${ }^{176}$ Godine 1459. piše on papi da je oltar sagradio od dobara kojima ga je Bog obdario i da je oltar opskrbio paramentima i dragocjenim nakitima; na tom oltaru se redovno obavlja božanska služba. Papa odgovarajući na Stjepanovu molbu podjeljuje oprost od sedam godina i toliko četrdesetnica svima koji na dan sv. Jurja posjete kapelu, pokaju se i dadu milostinju. ${ }^{177}$ Kao da je svaki od Frankopana želio sa svoje strane nekom darovnicom potvrditi svoju vezu sa Senjom. Tako i Dujam Slunjski 14. rujna 1487. godine dariva franjevački samostan u Senju da mu se svake godine o Miholji od njegovih godišnjih prihoda od mlina u Žrnovnici kod Ledenica daje 10 zlatnih dukata, a franjevci zauzvrat trebaju svake sedmice služiti misu za njihovo zdravlje i za njihove pokojne. ${ }^{178}$ Tu darovnicu potvrdio je poslije (1632.) Nikola IX. Frankopan. ${ }^{179}$

Propast plana o Senju kao središtu frankopanske državine i rušenje crkve i samostana sv. Franje izvan zidina

Nakon što im je kralj Matijaš oteo Senj, nisu Frankopani mogli tako izdašno pomagati franjevce. No, knez Dujam i u tim okolnostima obdaruje 1487. godine franjevački samostan u Senju s 10 dukata godišnje. ${ }^{180}$ Kraljevi, počevši od Matijaša, smatrali su se obveznima da preuzmu ne samo frankopansko pravo nego i njihove obveze prema samostanu. Matijaš uzima u zaštitu senjske franjevce da mogu ubirati prihode od kuća u Senju, koje pravo su dobili od pape. ${ }^{181} \mathrm{U}$ to

${ }^{175}$ M. SLADOVIĆ, 1856, 213. Kad su ti krajevi bili zaposjednuti od Turaka i opustošeni, samostan nije imao više nikakve koristi od darovanoga.

${ }^{176}$ P. LUKCSICS, 1938, br. 1026.

${ }^{177}$ ASV, Reg. Vat., vol. 499, f. 226v-227r. To nije samo oltar, nego i širi prostor oko njega. Vjerojatno je upravo pred tim oltarom Stjepan II. pokopao 1456. godine svoju suprugu Ižotu.

${ }^{178}$ Naši predšasnici veoma su štovali red sv. Franje "sub cuius nomine et vocabulo ecclesiam cum monasterio prope muros civitatis fundaverunt seu edificare fecerunt" (Vjestnik, II (1900), 1, 45). I dalje se upotrebljava izraz da su fratri "civitatis Segniae". Sladović ima godinu 1481. (M. SLADOVIĆ, 1856, 243-244) Za njega Magdić kaže da je više toga ispustio i krivo prepisao.

${ }^{179}$ M. SLADOVIĆ, 1856, 244-245.

${ }^{180}$ Vjestnik, II (1900), 1, 45.

${ }^{181}$ M. SLADOVIĆ, 1856, 226-231; Vjestnik, II (1900),1, 43 i 49. 
vrijeme u senjskom samostanu su observanti bosanske vikarije. ${ }^{182}$ Franjevci iz Bosne u velikom broju dolazili su na hrvatske prostore koji nisu bili pod Turcima i preuzimali samostane dotadašnjih konventualaca. Tako je to bilo i u Senju koji je pripadao provinciji Dalmaciji, Rapskoj kustodiji. Observanti kao reformirani franjevci imali su podršku papa i kraljeva. Papa Pavao II. podržavao je observante i dopustio im da preuzmu senjski samostan, a njegov nasljednik Siksto IV. zatražio je od kralja Matijaša 1478. godine da premjesti senjske konventualce na drugo mjesto, a samostan preda observantima. ${ }^{183}$ Svoju zaštitu i potporu samostanu dali su i Matijaševi nasljednici. Spomenuto je već kako Vladislav 1505. godine određuje da se od prihoda senjske mitnice daje samostanu godišnje 40 mletačkih denara, što su njegovi nasljednici Vladislav i Ludovik također potvrdili. ${ }^{184}$

Sve je više prijetila opasnost od Turaka. O tome je zapisao Mile Magdić: Budući da su polako Turci poslije osvojenja Like i Krbave (1528) skupa s martolozi (turski razbojnici) koji senjsku djecu lovljahu i Turkom prodavahu, sve to većma na senjsku okolicu navaljivahu. ${ }^{\text {} 85}$

Među objektima određenim za rušenje bili su i crkva i samostan male braće. ${ }^{186} \mathrm{O}$ tome nas uz Valvasora (prema M. Magdiću, str. 57) izvještava Pavao Ritter Vitezović: "1559. Razorisse sratri Kloštar s. Ferenca izvan Szenya: $i$ novoga nutripocesse zidatii..." ${ }^{187}$ Nalazimo potvrdu i u kamenom natpisu-grafitu koji je oko godine 1891. vidio u jednoj sobi na drugom katu tvrđave Nehaj Ivan Kukuljević Sakcinski i zabilježio ga (natpis nije sačuvan). Prema Kukuljeviću Sakcinskom taj natpis glasi: Na dan priblazene D. Marie Sviecharizze, ali od kandelabra, dosli jesu Turci do grada Senja, ali Senju nisu ništa naudili, nit skode napravili, jer su se Senjani hrabreno odnasli. Nego samo Turci opalise Klostar i crikvu Sv. Petra, od kojega Klostra nije ostalo nego samo stina od koje stine nachinio je pervi Ban Lenkovich napravit Fortizzu, da se brane od Turakah, na postenje Senjanov, i crikve sv Franje, da ih brani Bog i sveti Duh.

${ }^{182}$ Godine 1514. samostan je uključen u vikariju Bosna Hrvatska koja je imala svoje sjedište u samostanu svete Marije u Cetinu gdje je 1. siječnja 1527. godine izabran Ferdinand Habsburški za hrvatskog kralja. Od 1708. pa do odlaska franjevaca na Trsat pripadali su u hrvatsko-kranjskoj provinciji Sv. Križa (J. BURIĆ, 2002, 146).

${ }^{183}$ F. GONZAGA, 1587, 444. Spor konventualci/observanti zbog Senja trajao je i dalje jer se još 1490. godine konventualci tuže da su observanti senjski samostan na silu uzeli (Bullarium Franciscanum, Nova series, 1990, br. 1853).

${ }^{184}$ M. SLADOVIĆ, 1856, 228; Vjestnik, II (1900), 1, 46-47.

${ }^{185}$ M. MAGDIĆ, $1877,57$.

${ }^{186}$ Usp. A. GLAVIČIĆ, 1971, 26-27; M. MAGDIĆ, 1877, 57.

${ }^{187}$ P. RITTER VITEZOVIĆ, 1696, 151. Vidi: E. LASZOWSKI, MH, III, 1917, 11-13 i 25. Godine 1540. samostan je već srušen. 
Leta Gospodinova 1558. ${ }^{188}$ Prema Anti Glavičiću: "Sličan grafit, dvostruku sa urezanim latinskim slovima i jezikom, većim dijelom pokriven slojem maltera nedavno je otkriven u maloj prostoriji, nad samim ulazom u tvrđavu." 189

Senjski franjevci, zajedno s onima iz Trsata i Bihaća, potužili su se 1536. godine caru Karlu V. da se ne poštuju njihova prava i povlastice ${ }^{190}$, ali su već tada nastala takva vremena da im ni careva zaštita koja je usmeno uslijedila, nije mnogo značila. Senjski kapetan Ivan Lenković poslao je kralju Ferdinandu nedugo nakon toga plan obrane Senja. Po tom planu trebalo je srušiti do temelja franjevački samostan jer bi on mogao predstavljati veliku opasnost za sam grad u slučaju da ga zauzme turska vojska. Pored samostana i franjevačke crkve trebalo je srušiti i ostale građevine izvan gradskih zidina. Ferdinand je prihvatio Lenkovićev plan i 1540. godine srušeni su do temelja i crkva i samostan. Vjerojatno da je samostan i prije bio oštećen, ali je sve do 1540. godine još bio nastanjen. Tada se javiše knezovi Frankopani, ožalošćeni ne samo zbog toga što je uništena zadužbina njihovih predaka, nego i zbog toga što su oskvrnjeni njihovi grobovi. Negdje u rujnu te godine nađoše se u Cetinu Juraj Slunjski, Vuk Modruški i Nikola Tržački, a s njima je i Nikolin šurjak Stjepan Blagajski, i otuda uputiše protest kralju Ferdinandu protiv Lenkovićeva čina. Njihovi preci sagradili su uz velike troškove crkvu i samostan i svim potrebnim opremili. Crkva i samostan - kažu - nisu nikada štetili sigurnosti grada. Franjevci su ostali bez crkve i samostana, a kosti frankopanskih predaka, časnih i za državu zaslužnih ljudi, dane su psima da ih razvlače. Zatim mole da se franjevcima unutar zidina sagradi nova crkva i samostan. ${ }^{191}$ Ferdinand im odgovara 24 . listopada iste godine da Lenković nije na svoju ruku srušio kuće izvan zidina nego da je za to, nakon što su stvari proučene, on sam dao odobrenje. Što se tiče franjevaca, njima je dana na korištenje kapela Sv. Duha unutar zidina, a slaže se s time da se franjevcima sagradi u gradu novi samostan i nova crkva. ${ }^{192}$

Franjevci su i sami radili na tome da dobiju u gradu ono što su prije imali izvan grada, a kralj im je to tim lakše omogućio što ga je silila na to i obveza prema Frankopanima. Za gradnju novog samostana trebali su imati također

${ }^{188}$ I. KUKULJEVIĆ SAKCINSKI, 1891, 245, br. 819. Usp. A. GLAVIČIĆ, 1971, 26-27. J. Frančišković primjećuje: "Ovaj natpis sudeći po jeziku mogao je doduše kasnije nastati, ali utvrđuje tradiciju. Natpis je dosta nejasan pa su neki iz toga izvodili da je uz crkvu sv. Petra bio samostan sv. Franje, ili da je ondje bio neki ženski samostan."

${ }^{189}$ A. GLAVIČIĆ, 1971, 27

${ }^{190}$ M. SLADOVIĆ, 1856, 231-232.

${ }^{191}$ E. LASZOWSKI, $M H$, III, 1917, 11.

${ }^{192}$ E. LASZOWSKI, $M H$, III, 1917, 25. 
pristanak pape kojemu su uz svoju molbu priložili i Ferdinandovu dozvolu. Papa Pavao III. svojim pismom od 2. lipnja 1547. godine dao je svoj pristanak. ${ }^{193}$

Nemamo podataka kako je napredovala gradnja. Dana 14. lipnja 1550. godine, za vrijeme gvardijana Franje iz Klisa, neki Mikša Stipanović ostavlja franjevcima jednu kuću. Povelja o tome sastavljena je u samostanu sv. Franje u Senju. ${ }^{194}$ Svakako ne može biti riječ o onome izvan gradskih zidina. Izgleda da je već nova građevina osposobljena za stanovanje ili su pak franjevci svoj privremeni stan nazvali samostanom. Čini se da je samostan unutar senjskih zidina dobro napredovao jer je 1568. godine u njemu održan kapitul Cetinske kustodije pod predsjedanjem fra Ivana iz Senja. ${ }^{195}$

Kako je već rečeno, u grobnicama crkve sv. Franje bili su pokopani mnogi iz frankopanskog roda, među njima svakako i njihov djed Ivan V. (1393.), a vjerojatno i otac Nikola IV. (1432.). Malo je toga sačuvano i preneseno u novu crkvu koja je sagrađena u gradu. Sačuvana je ploča kneginje Ižote Frankopanke iz godine 1456. (rođene vojvotkinje aragonske i estenske, kćerke gospodara Ferrare i Modene, rano umrle žene Stjepana II. Frankopana, koja je umrla godine 1456.). Natpis na ploči glasi: HIC JACET CORPUS MAGNIFICAE DNAE IXOTE FILIE QUONDAM D.NICOLAI MARCHIONIS ESTENSIS ET CONSPORTIS MAGNIFICI DNI STEPHANI SEGNIE, VEGLIE ET MODROSSI COMITIS. ANNO MCCCCLVI DIE XXVI IANVARII. ${ }^{\prime 96}$ Ta je ploča, kao i neke druge, bila prenesena u novu crkvu sv. Franje u gradu. ${ }^{197}$

Iz citirane bule pape Pavla III. proizlazi kako je franjevcima dana na uporabu najprije crkva Sv. Duha u gradu, a onda im je u naknadu za porušenu crkvu i samostan izvan gradskih zidina sagrađena nova crkva i samostan u samom gradu $i$ to čini se na istom mjestu gdje se do tada nalazila, možda $u$ ruševnom stanju, prijašnja franjevačka crkva. ${ }^{198}$ Melita Viličić smatra da je franjevcima podignut novi samostan i crkva u gradu kraj crkve Sv. Duha. ${ }^{199}$ Još

${ }^{193}$ M. SLADOVIĆ, 1856, 234-236.

${ }^{194}$ Vjestnik, II (1900), 1, 48.

${ }^{195}$ F. GLAVINICH, 1648, 38.

${ }^{196}$ I. KUKULJEVIĆ SAKCINSKI, 1891, 237, br. 790.

${ }^{197}$ J. FRANČIŠKOVIĆ, 1931, 413

198 "Na tu nas misao da je crkva sv. Franje postojala baš na ovom mjestu još prije godine 1558. upućuju i nadgrobni spomenici ('lapides clamabunt') iz g. 1456.,1552.,1555. i 1556." (J. FRANČIŠKOVIĆ, 1931, 413-414).

${ }^{199}$ M. VIILIČIĆ, 1971, 105. A. Rački s pravom primjećuje da su se franjevci nakon rušenja njihovog samostana izvan zidina mogli privremeno smjestiti u neku od kuća koje su imali u gradu. (A. RAČKI, 1904, br. 32, 376) 
u vrijeme biskupa Markantuna de Dominisa (1602.) moglo se vidjeti ruševine franjevačkog samostana izvan grada.

\section{Crkva i samostan "unutar gradskih zidina"}

Na pročelju nove franjevačke crkve u gradu stavljena je ploča da je crkva sagrađena 1558. godine, tj. iste godine kada i Nehaj. ${ }^{200}$ Već je gore rečeno da je crkva bila sagrađena prije, ali je Lenković htio povezati gradnju Nehaja i crkve $\mathrm{u}$ isto vrijeme. ${ }^{201}$

U naknadu za porušeni samostan dobili su franjevci crkvu i zgradu u gradu. Ako je tu i prije bila crkva, kako neki misle, ona je bila malena i u ruševnom stanju te su je od temelja preuredili i proširili da uzmogne odgovarati svrsi $^{202}$, dok drugi misle da je riječ o sasvim novoj crkvi. ${ }^{203}$ Spomenici Franje Mudrovčića, brinjskog prefekta iz 1552. godine, bosanskog uskoka Petra Radoevića (Milašina) iz 1552. godine, Mate Gojčića iz Ličkog Novog iz 1555. godine i Jakova Suminića iz 1556. godine ugrađeni su izravno u novu crkvu jer je ona oko 1550. godine bila u građevnom smislu već dovršena. Moguće je da je kamenje zida na pročelju doneseno iz stare crkve.

Svi frankopanski spomenici koji se nalaze u novoj crkvi sv. Franje doneseni su iz stare crkve. Među njima je i gore spomenuta nadgrobna ploča frankopanske kneginje Ižote iz 1456. godine. Ne treba sumnjati da su frankopanski grb i kamena ploča s reljefom Isusa i franjevačkih svetaca također iz stare crkve. Zorislav Horvat smatra da je ta kamena ploča bila jedna od bočnih strana sarkofaga u kojemu je bilo položeno tijelo nekoga Frankopana. Meni se čini da je to upravo bio sarkofag Nikole IV. Frankopana (+1432.), čiji su se sinovi sastali u Brinju 1435. godine i odlučili da u senjskoj franjevačkoj crkvi bude grobnica svih Frankopana.

Iz pisma pape Pavla III. od 4. srpnja 1547. godine kojim dozvoljava rušenje franjevačkog samostana i crkve izvan zidina i gradnju novog samostana i crkve sv. Franje u gradu također proizlazi kako je franjevcima dana na uporabu

200 "REGNANTE SERENISSIMO PRINCIPE ET DNO DNO FERDINANDO DIVINA FAVENTE CLEMENTIA ROMANORUM. HUNGARIE BOHEMIE DALMATIE CROATIE ETC. REGE INFANTE HISPANIE ARCIDUCE AUSTRIE ETC. INVICTISSIMO TEMPORE CAPITANEATUS DOMINI JOHANIS LENKOVICH SVE MAESTATIS COMMISARII ET CAPITANEI MDLVIII."

${ }^{201}$ I. KUKULJEVIĆ SAKCINSKI, 1891, 244.

${ }^{202}$ J. FRANČIŠKOVIĆ, 1931, 413-414; B. LJUBOVIĆ, 2015-2016, 342-343.

${ }^{203}$ M. VILIČIĆ, 1970, 231. 


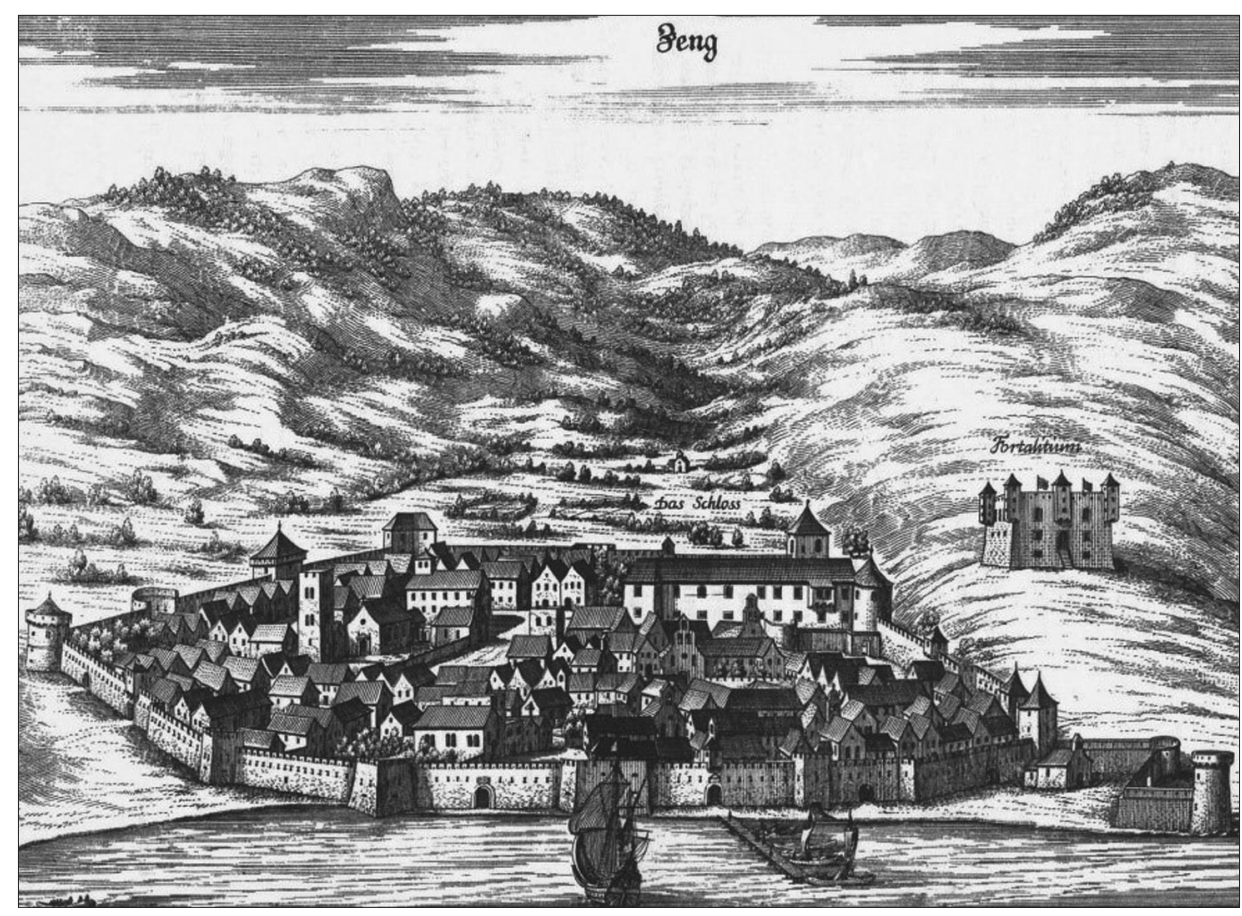

S1. 23. Veduta Senja iz 1689. J. V. Valvasora

(Die Ehre des Herzogthums Krain, Laibach, 72)

(izvor: Zagreb, Državni arhiv NRH: 1712)

najprije crkva Sv. Duha u gradu, a onda im je u naknadu za porušenu crkvu i samostan izvan grada podignuta nova crkva i samostan u gradu pokraj crkve Sv. Duha. ${ }^{204}$

Nova crkva sv. Franje bila je s vremenom dograđivana i obnavljana. Prema oskudnoj dokumentaciji teško je točno pratiti povijest njezine izgradnje. Sudeći po fotografijama, grafičkoj dokumentaciji i opisima, osim naknadno umetnutih četverouglastih prozora na pročelju 1863. godine i istovremeno postavljenog stepeništa pred glavnim ulazom, njezino glavno pročelje ostalo je autentično nepromijenjeno. ${ }^{205}$ Pročelje je izgrađeno od kamena klesanaca, urešeno lijepom ovećom rozetom i krasnim renesansnim portalom.

Potkraj 17. stoljeća Valvasorova veduta iz 1689. godine prikazuje toranj franjevačke crkve, očito kasnije dograđen, bez pokrova poput kule, sličan tada

${ }^{204}$ M. SLADOVIĆ, 1856, 234.

${ }^{205}$ J. FRANČIŠKOVIĆ, 1931, 414, 417. 
tornju katedrale, samo znatno niži. I on kasnije dobiva pokrov (1749.). Franjevci nisu baš svugdje davali važnosti tornju, a kapucini su ga sasvim ispuštali kod svojih crkava.

\section{Novi samostan}

Novi franjevački samostan spominje se u dokumentima iz 16. i 17. stoljeća. Godine 1554. u doba kada je samostan bio upravo u izgradnji, kralj Ferdinand I. određuje mu 4 forinta dohodaka senjske tridesetnice. ${ }^{206}$ Možda se potkraj 17. stoljeća samostanu dograđuje drugi kat ili se objekt samostana barem proširuje $\mathrm{u}$ drugom katu, a u svetištu se zatvara prozor do njega. O stanovitoj pregradnji samostana govori natpis nad vratima bivše blagovaonice u prizemlju (nekadašnja gostionica "Lipa") na dovratniku gotičke profilacije: "1693. O.A.M.D.G." (Omnia ad maiorem Dei gloriam). ${ }^{207}$

Samostan je građen tako da je s crkvom zatvarao oveće unutarnje dvorište "cortile" na koje se barem djelomično otvarao arkadama i krstastim svodovima u hodniku prizemlja. U nekim kasnijim planovima u njemu je urisana zelena površina. Duljim pročeljem samostan je orijentiran na glavni trg pred kaštelom (Cilnicu) koji je često bio centar događaja vezanih uz povijest grada. Objekt samostana se tako spominje i u opisu bune protiv porodice Vukasović 1720. godine. ${ }^{208}$

Iako se u dokumentima samostan sv. Franje spominje 1554., 1612. i 1720. godine ${ }^{209}$, ništa iz njih ne saznajemo o samom objektu. Ni grafička dokumentacija ne daje neke detaljnije tlocrtne podatke o tom objektu, kao ni o drugim sakralnim objektima. Ipak Valvasorova veduta iz 1689. godine prikazuje uz katedralu još jedan veći sakralni objekt (kojih je u Valvasorovo vrijeme bilo $14^{210}$, a tijekom poznate povijesti Senja tridesetak) - i uz njega toranj poput kule, kao kod katedrale, fortifikacijskog karaktera. Tek veduta iz 1749. godine pokazuje toranj crkve sv. Franje s baroknim pokrovom (kakav je i danas na njemu) uz natpis "Franc. Kloster", dok je zvonik katedrale tada još bez pokrova.

Unutrašnjost crkve sv. Franje imala je brojne natpise, među njima i jedan iz 1749. godine koji spominje obnovitelja senjske katedrale biskupa Čolića; u tekstu je povezan i s crkvom sv. Franje. Natpis glasi: "ILLUSTRISSIMO

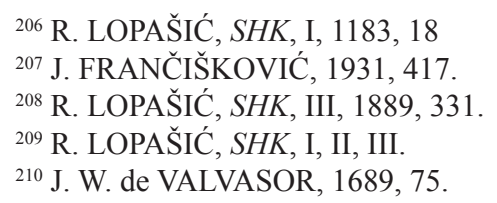




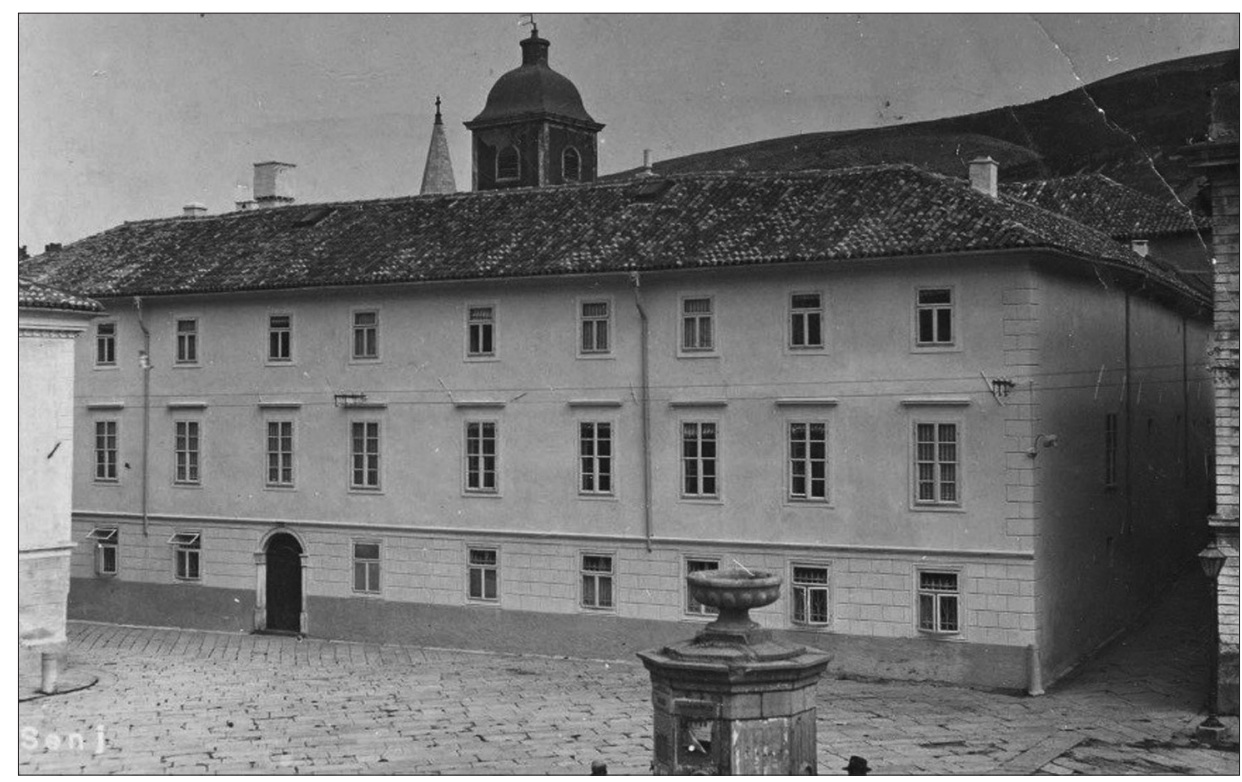

Sl. 24. Samostan franjevaca (izvor: Gradski muzej Senj)

REVERENDISSIMO DOMINO DOMINO GEORGIO WOLFGANGO CHIOLICH LEWENSBERG EPICOPO SEGNIE MODRUSSIE ET CORBAVIE ABBATI S.GEORGII INFULATO. IN ARTE GUBERNANDI MAGISTRO, IN SCIENTIIS TAM SACRIS QUAM PROFANIS DOCTORI, IN ZELO ANIMARUM VIRO APOSTOLICO, IN AMORE SERAPHICE RELIGIONIS PATRI, ECCLESIAM IN HONOREM S. FRANCISCI SOLEMNI RITU DEDICANTI VIII KALEND. FEB. MDCCIL. MONUMENTUM HOC FRATRES MINORES GRATI POSUERE."211

Kako se biskupu Čoliću pripisuje i dogradnja lijeve lađe katedrale, a s obzirom na gornji natpis koji govori o svečanom posvećenju crkve sv. Franje, nameće se pitanje je li on dao obnoviti i tu crkvu i do koje mjere?

U plan grada iz 1763. godine urisan je i tlocrt crkve sv. Franje više-manje simbolično, kao trobrodne bazilike. Plan grada iz 1779. godine sliči suvremenom urbanističkom snimku grada te ga se može uzeti kao vrlo preciznoga. Konture crkve sv. Franje odgovaraju arhitektonskom snimku iz 1894. godine s naznačenim tlocrtom samostana i tornja. U planovima grada iz 1785. i 1788. godine urisan

${ }^{211}$ I. KUKULJEVIĆ SAKCINSKI, 1891, 253. 


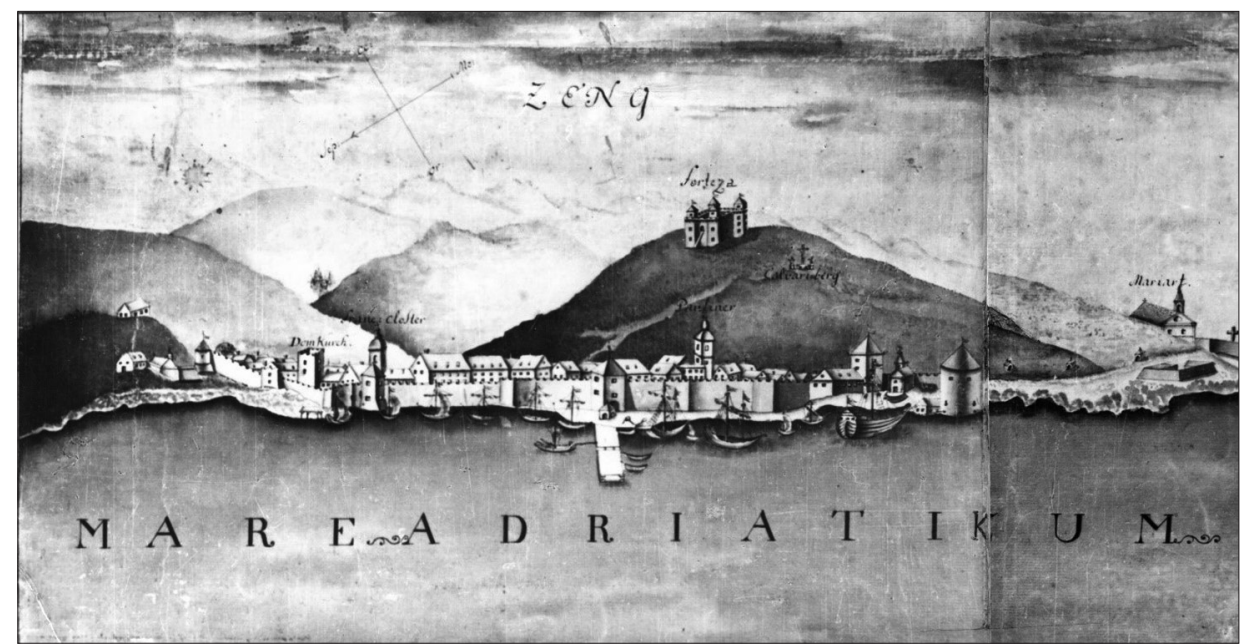

S1. 25. Veduta Senja iz 1749., A. Waldschitz (izvor: Beč, Ratni arhiv: B IX c 850)

je blok crkve i samostana, označen toranj, urisano zelenilo unutarnjeg dvorišta samostana i u legendi upisano: k-Franciscaner Closter und Kirche. ${ }^{212}$

Kada su senjski franjevci silom napustili svoj samostan u Senju, senjski biskup Ježić, pošto mu je uspjelo od kralja Franje I. ishoditi dozvolu za otvorenje sjemeništa od 24. studenog 1804. godine preuređuje bivši franjevački samostan za bogoslovno učilište Senjsko-modruške biskupije ili Krbavske biskupije. Sjemenište je svečano otvoreno 1. studenoga 1806. godine. ${ }^{213}$

Sjemenište je zahvaćeno požarom 31. prosinca 1810. godine i tek je 1816. godine popravljeno. Na planovima Senja iz 1839. i 1857. godine urisan je ovaj objekt kao "Seminarium", a kontura tlocrta crkve sa znatno manjim dimenzijama s natpisom "Franciskaner Kirche". Iz 1875. godine je kameni spomenik u klaustru bivšeg samostana, tj. sjemeništa:

"PRAECLARA CUSTOS VIRGINIUM SPES NOSTRA COELI GAUDIUM SYRTES DOLOSAS SMOVE FLUCTUS TOT INTER DEVIIS TUTAM RECLUDE SEMITAM. VIRGINI SINE LABE CONCEPTAE TUTO IN ADVERSIS PRAESIDIO ELECTAE MATRI JUNIOR CLERUS ANNO REPARATAE SALUTIS MDCCCLXXV POSUIT."

Godine 1898. zgradu sjemeništa restaurirao je biskup Maurović. ${ }^{214}$ Nakon više od sto godina svojeg djelovanja, sjemenište je 1919. godine zbog premalog

${ }^{212}$ M. VILIČIĆ, 1971, 105-106.

${ }^{213}$ M. SLADOVIĆ, 1856, 290.

${ }^{214}$ P. TIJAN, 1931, 38. 
broja klerika zatvoreno i ono malo bogoslova poslano je u Zagreb. U sjemenišnoj zgradi iza toga bijahu privatni stanovi za dva kanonika, a u ostalim prostorijama bila su smještena vjerska društva. Senjsko sjemenište odgojilo je veliki broj pravih narodnih svećenika, osobito u prvoj polovici 19. stoljeća, od kojih su mnogi po svojim župama sami osnivali škole i u njima poučavali. ${ }^{215}$

Senjski biskup dr. Ivan Starčević ponovno je otvorio sjemenište 1933. godine s 30-40 bogoslova, ali je već 1940. godine prije Drugog svjetskog rata ponovno zatvoreno. Sljedeće godine, 1941., u zgradu su smješteni uredi Velike župe Vinodol i Podgorje do 1943. godine. Iza toga zauzeše je partizani. Zgrada je u ratu 1943. godine stradala prigodom bombardiranja, osobito krov do crkve sv. Franje koja je do temelja porušena. Iza rata zgrada je ponovno uređena za urede N.O. Kotara Senj, a danas je sjedište Općinske skupštine Senj. Temeljito je restaurirana 1977./1978. godine. Zgrada je nacionalizirana i biskupija nije dobila za nju nikakve odštete, dok je gotovo do današnjih dana (2019.) u vlasništvu i posjedu sjemenišnog vrta na Travici gdje postoje dvije zgrade za stanovanje. ${ }^{216}$

\section{Nova crkva}

Nova crkva ima tri lađe: pobočne su nešto kraće od srednje; ovaj produžetak srednje lađe sav je isto od klesanog kamena i tu su se na srednjoj sjevernoj strani nalazila jedna pobočna vrata koja su kasnije naknadno probijena. U lađi nad lukovima nije bilo prozora, kako su to na katedrali jer je u ovu manju crkvu dolazilo dosta svjetla na veliku rozetu na pročelju, dok su svetište još rasvjetljavala dva polukružna prozora. Ovima su kasnije, kad su pokrajnji oltari dobili visoke retable i zastrli polukružne prozore, dodani u svakoj kapeli po dva prozora pačetvorinska radi bolje rasvjete. ${ }^{217}$

Najstariji opis crkve sv. Franje u gradu Senju daje Ivan Kukuljević Sakcinski u svojim Putnim uspomenama iz 1856. godine. ${ }^{218}$ Sličan opis crkve Mile Magdića iz 1877. godine ${ }^{219}$ razlikuje se samo u nekim detaljima. Crkva sv. Franje ima tri lađe: srednja je široka $8,50 \mathrm{~m}$, a svaka pobočna $4 \mathrm{~m}$. Cijela crkva dugačka je 29,70 m, a široka 16,50 m. ${ }^{220}$ Još imamo opise Gjure Szaba ${ }^{221}$, Pavla

${ }^{215}$ P. TIJAN, 1931, 38.

${ }^{216}$ M. VILIČIĆ, 1970, 234.

${ }^{217}$ J. FRANČIŠKOVIĆ, 1931, 415.

${ }^{218}$ I. KUKULJEVIĆ SAKCINSKI, 1873, 24.

${ }^{219}$ M. MAGDIĆ, 1877, 18-31.

${ }^{220}$ J. FRANČIŠKOVIĆ, 1931, 417.

${ }^{221}$ G. SZABO, 1940, 42-43. 


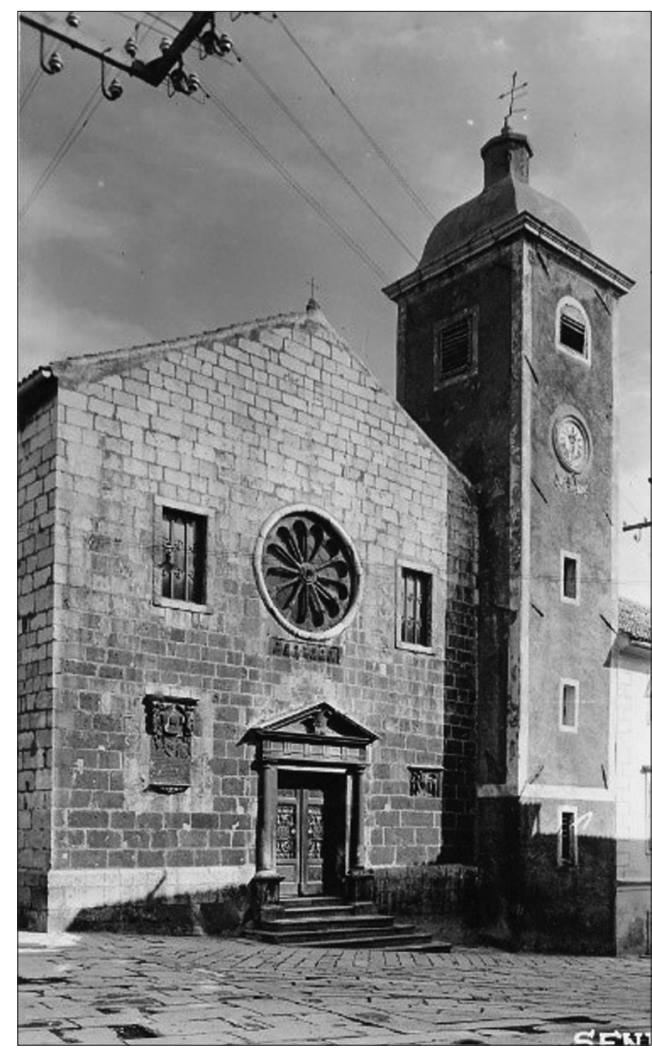

S1. 26. Sv. Franjo prije rušenja

(izvor: Gradski muzej Senj)
Tijana 222 i Josipa Frančiškovića. Najopširniji opis crkve dao je Josip Frančišković, senjski kanonik i profesor bogoslovije. ${ }^{223}$ Frančišković je prenio uglavnom sve što su rekli njegovi prethodnici pa ćemo $u$ ovom opisu njega slijediti.

Crkva je građena u stilu romanske bazilike $\mathrm{s}$ posebno lijepim pročeljem sagrađenim od tesanog kamena. Ulazna su vrata pravokutna u stilu renesanse $\mathrm{s}$ dva polustupa (kolone) uz pragove; povrh je trokut - simbol Sv. Trojstva u kojem je štit s reljefom sv. Franje kako na brdu Alvernu prima rane s križa. U sredini pročelja nalazio se okrugli prozor - rozeta - slična onoj na katedrali. Ispod rozete bilo je uzidano sedam svetaca u tehnici kamenog reljefa. Čini se da je riječ o Isusu s apostolima, a Zorislav Horvat smatra da je to vjerojatno jedna bočna strana sarkofaga koji je bio u staroj crkvi "izvan grada". Uz rozetu su bila iz novijeg vremena probijena dva velika prozora koja ne odgovaraju sklopu pročelja. S jedne strane ulaznih vrata (portala) resila su pročelje dva grba; lijevo grb nekog Frankopana u kojemu su elementi starog grba i novi frankopanski grb s lavovima koji lome kruh. To je najstariji grb s lavovima i smatram da je to grb Nikole IV. Frankopana koji je umro 1432. godine i pokopan u crkvi sv. Franje na Travici. Grb podržavaju dva anđela (putta) uz koje stoji po jedan redovnik i to franjevac i pavlin. ${ }^{224} \mathrm{~S}$ druge

${ }^{222}$ P. TIJAN, 1931, 35.

${ }^{223}$ J. FRANČIŠKOVIĆ, 1931, 411-423. Ovaj opis ćemo slijediti, ispuštajući što smatramo neispravnim, nepotrebnim i suvišnim.

${ }^{224}$ Mislim da je riječ o pavlinu jer drži u ruci grančicu kao simbol stabla koje se redovito prikazivalo na pavlinskim grbovima. Inače je Nikola IV. Frankopan bio tijesno povezan s pavlinima i franjevcima. 
strane portala (desno) je grb senjskog kapetana, generala Ivana Lenkovića ispod kojeg je bila ploča s natpisom iz 1558. godine. ${ }^{225}$ Vanjske stube pred crkvom, odnosno pred portalom, sagradio je 1863. godine patricij Jože Marković. Uz pročelje nalazio se na desnoj strani (do samostana, odnosno sjemeništa) toranj s više katova s malim prozorčićima, dok su na vrhu kod zvona bili na sve četiri strane veliki prozori s polukružnim završetkom. Kupola tornja bila je šesterokračna piramida s pijetlom koji se prema vjetru okretao. Na tornju je bila i onda neuporabiva ura. Kako toranj ne odgovara pročelju, znak je da je kasnije građen i to najprije bez pokrova, poput kule, a kasnije je stavljena kupola.

Unutrašnjost crkve bila je razdijeljena u tri lađe: pobočne su lađe bile nešto kraće od srednje; ovaj je produžetak srednje lađe prema pročelju bio sav od istog tesanog kamena (možda je cijelo pročelje od kamena tesanca od prijašnje crkve) i tu su u produžetku srednje lađe bila kasnije probijena pobočna vrata.

\section{Crkveni namještaj}

Svetište (sanktuarij) imalo je ravni strop i završavalo je ravnom apsidom, malo koso položeno prema ulici otraga. U svetištu je bio glavni oltar, drveni u baroknom stilu. U sredini retabla bila je slika patrona crkve, sv. Franje Asiškog, nad kojom je stajao barokni kip Madone (reljef Imakulate) u bogato načičkanom plaštu i s krunom. Sudeći prema stilu, veliki bi oltar poticao iz polovice 18. stoljeća kad je crkva u namještaju dobila svoj zadnji oblik te ju je biskup Čolić svečano posvetio 25. siječnja 1749. godine kako se čita na spomen ploči koja je stajala nad ulazom u sakristiju. ${ }^{226}$ Menza glavnog oltara (kao i sv. Vinka Fererskog i sv. Ante) bio je ogroman komad (blok) iz domaćeg kamena (dužina 3, m širina $1,50 \mathrm{~m}$ i visina $1 \mathrm{~m}$ ) tako da je sve - i menza i podnožje (stipes) nerazdjeljivo. Taj je kameni blok neizbrušen i zato je optočen drvom pa tako izgleda da je oltar drveni. Bit će da je ova menza još iz vremena gradnje crkve kad još nije bilo retabla, nego je valjda oltarna slika bila izvješena na zidu apside. Odatle je valjda ostao običaj u ovoj crkvi da se mjesto titulara izvjese druge slike svetaca kad se ovi u njoj slave. Crkva je građena za vrijeme Tridentinskog sabora (1545. 1563.), na kojem je bio i tadašnji senjski biskup fra Juraj Živković pa je svakako prema saborskoj odredbi došao i tabernakul na glavni oltar. ${ }^{227}$ Kasnije je stavljen

${ }^{225}$ I. KUKULJEVIĆ SAKCINSKI, 1891, 244, br. 816. Kako je već gore rečeno, crkva je bila u funkciji prije te godine, ali je graditelj želio staviti godinu kada je cijeli projekt vezan uz izgradnju Nehaja dovršen: od rušenja prijašnjih zgrada do izgradnje novih.

${ }^{226}$ I. KUKULJEVIĆ SAKCINSKI, 1891, 253-254, br. 852.

${ }^{227}$ J. FRANČIŠKOVIĆ, 1931, 416. 
novi tabernakul, dok je ovaj stari 1749. godine premješten u pokrajnju kapelu tzv. "Crne Gospe" ili Majke Božje od Loreta. Tabernakul je postavljen samo na sredinu oltara i nije bio učvršćen.

Svetište od srednje lađe dijelila je željezna ograda koja služi za pričest vjernika. Drvena propovjedaonica je istog stila kao i oltar, stavljena oko 1740. godine i rese je drveni reljefi četiriju crkvenih naručitelja; na njezinu krovu diže se anđeo s trubom. U vrijeme kada je crkva građena, uvedene su i klupe za vjernike u srednjoj lađi pa možemo pretpostavljati da su i ovdje bile. Klupe prije rušenja crkve bile su novijeg datuma. Kako je crkva bila samostanska, a ne župna, u njoj nije bilo krstionice ni spremište za sv. ulje.

U pobočnim lađama u presvođenim kapelama uza zid smješteni su pobočni oltari po tri u svakoj lađi i to ovim redom:

U lijevoj lađi počevši od ulaza:

1) oltar sv. Antuna Padovanskog, drven; u niši do oltara nalazilo se lijepo veliko starinsko gotičko raspelo od drva, nepoznatog datuma (šteta što je bilo prebojano),

2) oltar sv. Josipa,

3) oltar Majke Božje Karmelske, mramorni koji je na prednjoj strani menze bio urešen mramornim reljefom na antependiju Blažene Djevice Marije sa sinčićem u naručju. U istoj lađi kasnije je dograđena posebna kapela (kraj svetišta) s mramornim baroknim oltarom Majke Božje od Zdravlja ili Loreta, nazvane "Crna Gospa" zbog crnom bojom oličenih obraza, dok je sam kip od bijelog mramora. ${ }^{228}$ Kapela je kasnije dobila dograđena vrata probijena u zidu crkve i mali prozorčić. Iz kapele je ulaz na propovjedaonicu.

U desnoj lađi počevši od sakristije (koja je bila hodnikom vezana sa samostanom) bili su oltari:

1) oltar sv. Vinka, drveni, što ga je podigao 1767. godine Franjo Rosenfeld,

3) oltar sv. Franje Paulskog na kojem je osobito vrijedna oltarna slika talijanske škole,

2) oltar sv. Ivana apostola i evanđelista, mramorni.

Na svim oltarima sa strane titulara bilo je kipova franjevačkih svetaca. Oltari sv. Ivana i Majke Božje Karmelske bili su od kamena, a svi ostali drveni; potječu iz 18. stoljeća. Nisu imali posebne umjetničke vrijednosti, ali su dobra djela svog vremena.

${ }^{228}$ Danas je taj kip u katedrali na desnom stupu trijumfalnog luka. Do nedavno je bio na zidu u dnu svetišta gdje je danas raspelo. 
Nad ulazom u srednju lađu nalazilo se pjevalište (kor) s orguljama koje su bile postavljene možda tek u 19. stoljeću, a novije su bile iz 1904. godine. Iz svetišta i pokrajnje lađe ulazilo se u sakristiju čiji je namještaj bio novijeg datuma. Od starine nema ništa u njoj. Kad su franjevci morali napustiti Senj, sve su sa sobom odnijeli. Ostao je jedino kip sv. Franje koji se izlaže u crkvi na Porcijunkulu, a možda i monstranca koja je u franjevačkom obliku: franjevac raskriljenim rukama podržava zrake oko lunule, držak sv. Franje s ranom na prsima. Tu je bila i jedna Madona od umjetničke vrijednosti i manje vrijedna slika Spasitelja uza stup bičevanja, dar patricijske obitelji Accurti (nekad je stajala kod oltara sv. Ante).

Crkva je od svog početka imala dovoljno svijetla koje je dolazilo kroz dva polukružna prozora u svetištu sa svake strane oltara, kroz šest (tri sa svake strane) polukružnih prozora u pobočnim lađama i kroz veliku rozetu na pročelju. U svetištu je nestalo desnog prozora kad je bio nadograđen drugi kat samostana oko 1693. godine kad je podignuta i uređena blagovaonica, kako se to razabire iz natpisa na vratima blagovaonice. Kad su u 18. stoljeću pokrajnje menze dobile retable, bili su zastrti polukružni prozori i postalo je u crkvi dosta tamno. Zato su u svakoj kapeli ispod polukružnih prozora, sa svake strane oltara po jedan. Kad su još orgulje zastrle rozetu, crkva je opet bila u tami. Tada je uprava crkve uz rozetu probila 1863. godine dva velika prozora koja su davala dovoljno svijetla. Godine 1930. u crkvu je uvedena električna rasvjeta.

\section{Svečanosti u crkvi}

Crkva je bila usko povezana sa životom Grada. ${ }^{229}$ Bilo je više blagdana i svečanosti u crkvi sv. Franje koje su vjernici rado pohađali još od franjevačkih vremena kao što su križni put u korizmene nedjelje, blagdan Imena Isusova na drugu nedjelju po Bogojavljenju, Bezgrješno Začeće Blažene Djevice Marije sa zornicama kroz osminu (s posebnom pjesmom "Marija se zače danas"), Porcijunkula na 2. kolovoza s kipom sv. Franje izloženim usred crkve, pa blagdani sv. Josipa i sv. Ante Padovanskog, oba s devetnicom. Svibanjsku pobožnost 1864. godine i karmelsku pobožnost 1863. godine uveo je s bratovštinom osobno pomoćni biskup Vjenceslav Soić. U crkvi sv. Franje obavljala je senjska gimnazija mladež svoje vjerske dužnosti.

${ }^{229}$ B. LJUBOVIĆ, 2015-2016, 345. 


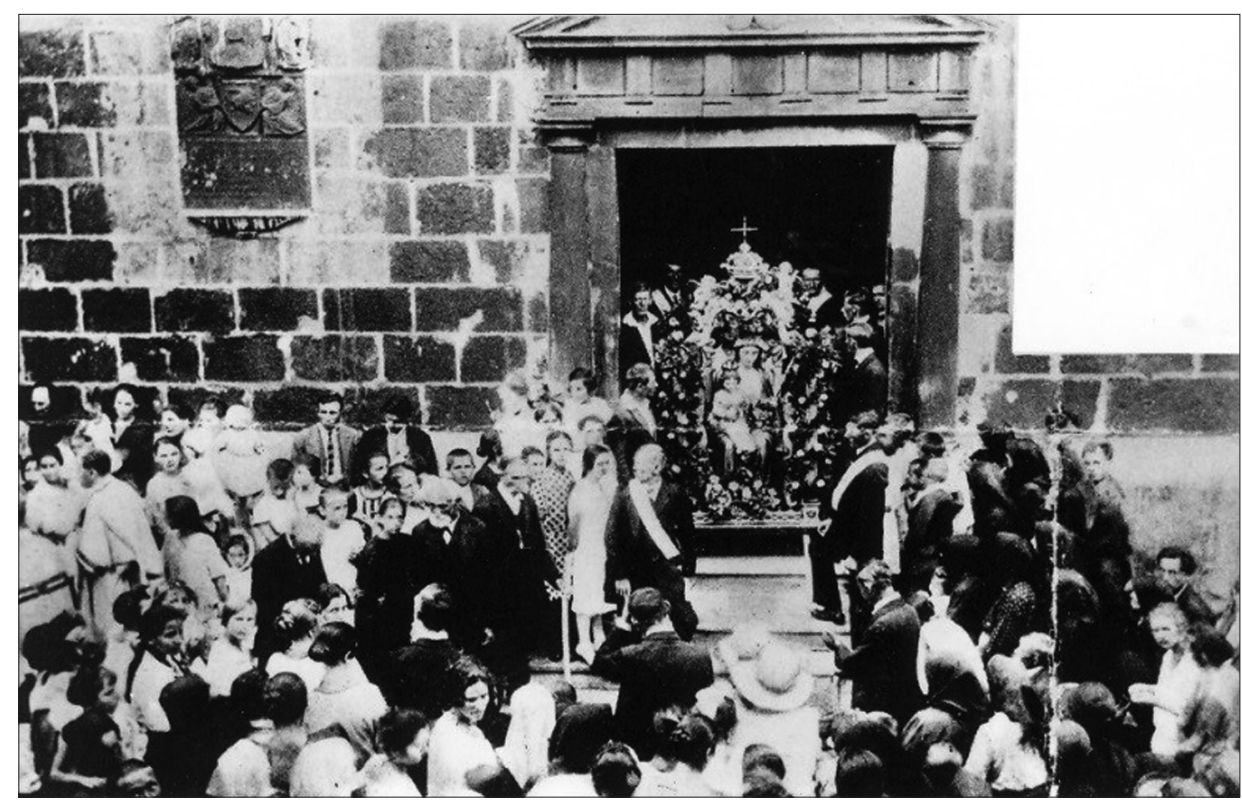

S1. 27. Crkva sv. Franje-svečanost proslave Majke Božje Karmelske (izvor: Gradski muzej Senj)

\section{Grobovi u crkvi sv. Franje}

Posebna povijesna vrijednost crkve sv. Franje u gradu Senju bila je ponajviše po tom što je tijekom 16. i početkom 17. stoljeća ${ }^{230}$ bila mauzolej senjskih uskoka i uglednih građana. Tradicija da su se u njoj pokapali zaslužni ljudi vezana je uz staru franjevačku crkvu s frankopanskim grobnicama izvan gradskih zidina. Cijela je, naime, srednja lađa nove crkve sv. Franje u gradu bila popločena nadgrobnim pločama uskočkih junaka i vojvoda te uglednih senjskih patricija. Upravo ti grobovi i njihove nadgrobne ploče dragocjeni su spomenici grada Senja i njegove povijesti. I baš zbog toga imala je ova crkva izuzetno značenje za grad Senj.

Prema Mili Magdiću²31, koji je prvi i točno prepisao sve tada (1877.) čitljivije natpise s nadgrobnih ploča (a to su kasnije potvrdili Ivan Kukuljević

${ }^{230}$ Blaženka Ljubović popisala je inventar Sv. Franje, s popisom ploča i tekstom koji je na njima pa nakon Kukuljevića Sakcinskog i Magdića imamo ne samo popis, nego i popravljeno čitanje te stanje inventara iz Sv. Franje. Stoga nema potrebe ponavljati što je rečeno i dobro prikazano (B. LJUBOVIĆ, 2015-2016, 341-442).

${ }^{231}$ M. MAGDIĆ, 1877, 9-29. 
Sakcinski i Pavao Tijan), u crkvi sv. Franje registrirane su 33 grobnice. Među nadgrobnim pločama najstariji i ujedno najljepši senjski lik je spomenik nadgrobna ploča Ižote Frankopanke, rođene kneginje aragonske i estenske (od Este), kćerke gospodara Ferrare i Modene, koja se udala za Stjepana II. Frankopana 1446. godine, rano umrla 1456. godine i bila pokopana $\mathrm{u}$ frankopanskoj grobnici u staroj franjevačkoj crkvi na Travici. Kasnije je njezina nadgrobna ploča prenesena u novosagrađenu crkvu sv. Franje u gradu i zazidana za oltarom. Reljef na kamenu prikazuje pokojnicu (ili ženu općenito) kako leži na odru $\mathrm{s}$ prekrštenim rukama. U gornjem lijevom uglu nalazi se frankopanski grb, a u desnom aragonski i estensko-

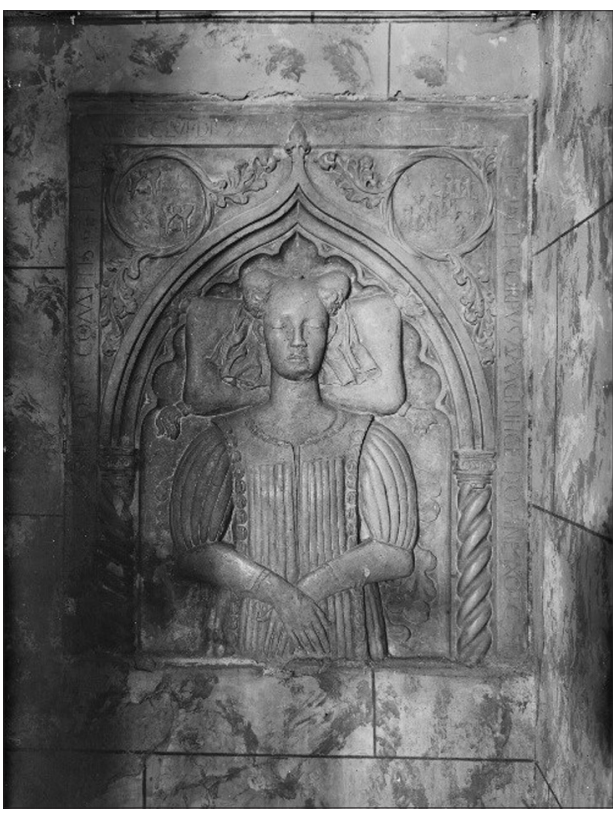

Sl. 28. Nadgrobna ploča Ižote Frankopanke u crkvi sv. Franje prije rušenja (izvor: fotoarhiv HAZU) modenski grb. Natpis na ploči glasi ${ }^{232}$ : HIC IACET CORPVS MAGNIFICE DOMINE IXOTE FILIE quodam D. Nicolai Murchionis Estensis et consortes magnifici Dni Stephani Segnie, Veglie et ModruSSIEQVE COMITIS. aNNO MCCCCLVI DIE XXVI IANVARII." (Kukuljević Sakcinski donosi duži natpis, upisano velikim i malim slovima). Vjekoslav Klaić donosi sliku nadgrobne ploče kneginje Ižote, kao i hrvatski prijevod natpisa: "Ovdje počiva tijelo velemožne Izote kćeri pok. gospodina Nikole, markgrofa estenskoga i supruge velemožnoga gospodina Stjepana kneza senjskoga, krčkoga i modruškoga. Godine 1456. dana 26. siječnja". ${ }^{233}$

Prigodom restauracije crkve sv. Franje 1888. godine kustos crkve i ravnatelj sjemeništa, kanonik Gaetan Bedini, dao je povaditi sve nadgrobne ploče s poda crkve i uzidati u stijene crkve i svetišta radi očuvanja od propasti jer su nekoje hodanjem već sasvim izlizane te se ne mogu ni pročitati. Grobovi su zazidani betonskim podom (brušenim). Nažalost, nije o tome sačuvan

${ }^{232}$ G. SZABO, 1940, 43.

${ }^{233}$ V. KLAIĆ, 1991, 241-242. 
nikakav zapisnik pa ne znamo kako su te ploče po podu bile poredane niti što se uz sanduke sa smrtnim ostacima u otvorenim grobovima još nalazilo. Prema Valvasorovom opisu Senja 1689. godine ${ }^{234}$, poznato je da su uskoci prema starom običaju bili pokapani sa svojim oružjem i ostalim znakovima. Sve radove oko otvaranja grobova nadzirao je sam Bedini bez zapisnika i prisutnosti drugih osoba te je takav postupak izazvao u građanstvu famu da je Bedini u interesu nekog inozemnog muzeja opljačkao uskočke grobove. Nadgrobne ploče, dok su bile na podu (in situ), nisu bile fotografirane pa se ne zna njihov položaj. Zato su se pronosili nepovoljni glasovi o kanoniku Bediniju, tim više što se poslije kao riječki župnik loše odnosio prema hrvatskom puku i njegovoj kulturi; u doba fašizma jedna ulica u Rijeci dobila je njegovo ime. ${ }^{235}$ No, Frančišković kaže da su nekoji živući svećenici (1931.) koji su tada bili klerici pratili (iako potajno) iskapanja i nisu ništa vrijedno zapazili te je sve iskopano opet zatrpano. ${ }^{236}$ I radnici su bili domaći ljudi pa bi bili razglasili da su što opazili, a i državne bi vlasti to spriječile. Svakako je u grobovima moglo biti stvari koje bi za našu povijest bile važne, ali ukoliko nisu istrunule, mogle su još i prije netragom iščeznuti pa Bedini, ako je možda i imao kakvu zlu nakanu, nije ništa vrijedno našao, kaže Frančišković.

Mile Magdić2 ${ }^{237}$, koji je prije restauracije crkve prvi točno popisao sve čitljive natpise s nadgrobnih ploča, registrirao je 32 grobnice, što su kasnije potvrdili i Kukuljević Sakcinski i Pavao Tijan koji ih također nabraja ${ }^{238}$ prema redoslijedu kako su uzidane u stijene crkve i svetišta. To isto je učinio i Frančiškovićc ${ }^{239}$, dok Ante Glavičić kaže da su prigodom restauracije bile registrirane 33 grobnice. ${ }^{240}$

Ploče su bile uzidane ovim redom (kako donosi Tijan):

a) u lijevoj lađi (iza križa u kapeli sv. Ante):

1) Ivan Miovčić (+1690), senjski plemić i žena Magdalena Homolić;

b) na lijevim stupovima srednje lađe:

2) Matej Tvrdislavić (+1578), senjski vojvoda;

3) Vid Čudinović (+1659), senjski plemić i žena Margareta Homolić;

c) u kapeli Majke Božje Loretske na podu pred oltarom s hrvatskim natpisom:

${ }^{234}$ J. W. de VALVASOR, 1689, 75.

${ }^{235}$ G. SZABO, 1940, 42.

${ }^{236}$ J. FRANČIŠKOVIĆ, 1931, 420.

${ }^{237}$ M. MAGDIĆ, 1877, 19-29.

${ }^{238}$ P. TIJAN, 1931, 36-37.

${ }^{239}$ J. FRANČIŠKKOVIĆ, 1931, 421.

${ }^{240}$ A. GLAVIČIĆ, 1966, 412; M. VILIČIĆ, 1970, 235-236. 
4) Francisko Rožanić (+1759) i njegovi sinovi

d) u svetištu počevši s lijeva do vrata sakristije:

5) Antun Stipšić (+1607.), postavio sin, zapovjednik senjske tvrđave

6) Matej de Blasiolis (+1564), senjski patricij

7) Matej Gojčić-Mogoroević (+1550), iz Like, građanin senjski

8) Fridrik Portner (+1682), senjski kapetan, ulomak natpisa

9) Vinko Bathalia (+1564.), žena Helena

10) Franjo Mudrovčić (+1552.) prefekt Brinjana, ranjen u boju

11) Andrija Skradinjanin (+1689.), ledenički dvorski župan, senjski plemić

12) Marko Radibratović (+1587.)

13) IŽOTA FRANKOPANKA (+1456.) žena Stjepana Frankopana (vidi gore natpis).

14) Jakov Suminić $(+1556$.)

15) Juraj Celović (+1693.), građanin senjski

16) Petar Radojević Bošnjak (+1652.) (Milašin) bosanski uskok

17) Dominik Miletić (+1641.) arhiđakon senjski

e) U srednjoj lađi na desnim stupovima:

18) Juraj Desantić (+1707.) plemić i vojvoda senjski

19) Bassani Sachi (+1552.) patricij senjski

f) Pod korom od desna prema vratima:

20) Pavao Lasinović (+1588.) vojvoda senjski

21) Juraj Hreljanović ili Sfenda (1587.), senjska .patricij.porodica

22) Geržanić Ragnac (Geržani Kranjac) (+1552.)

23) Ploča s nečitljivim natpisom

24) Grgur Parižević (+1561.), knez i vojvoda senjskih vojnika

25) Vinko Chararadić $(+1580)$

26) Vinko Smoljan (+1587.) vojvoda i građanin senjski

27) Posve izlizana ploča

28) Razaznaje se samo grob

29) Ivan Demelli de Lewensfeld (+1720.) patricij i kapetan senjski

30) Nečitljiv natpis

31) Ivan Vukotić (+1558.)

32) Vinko Brozović (+1610.) vojvoda (ovu ploču ne spominje Tijan).

Pored ovih ploča ima još jedna s grbom kralja Matijaša Korvina kod malih vrata nad škropionicom. Nad vratima sakristije su još dvije ploče, od kojih je jednu postavio senjski kapetan Rudolf Edling svojoj supruzi 1693. godine. Drugu postaviše franjevci senjskom biskupu Jurju Čoliću 1749. godine kad je 


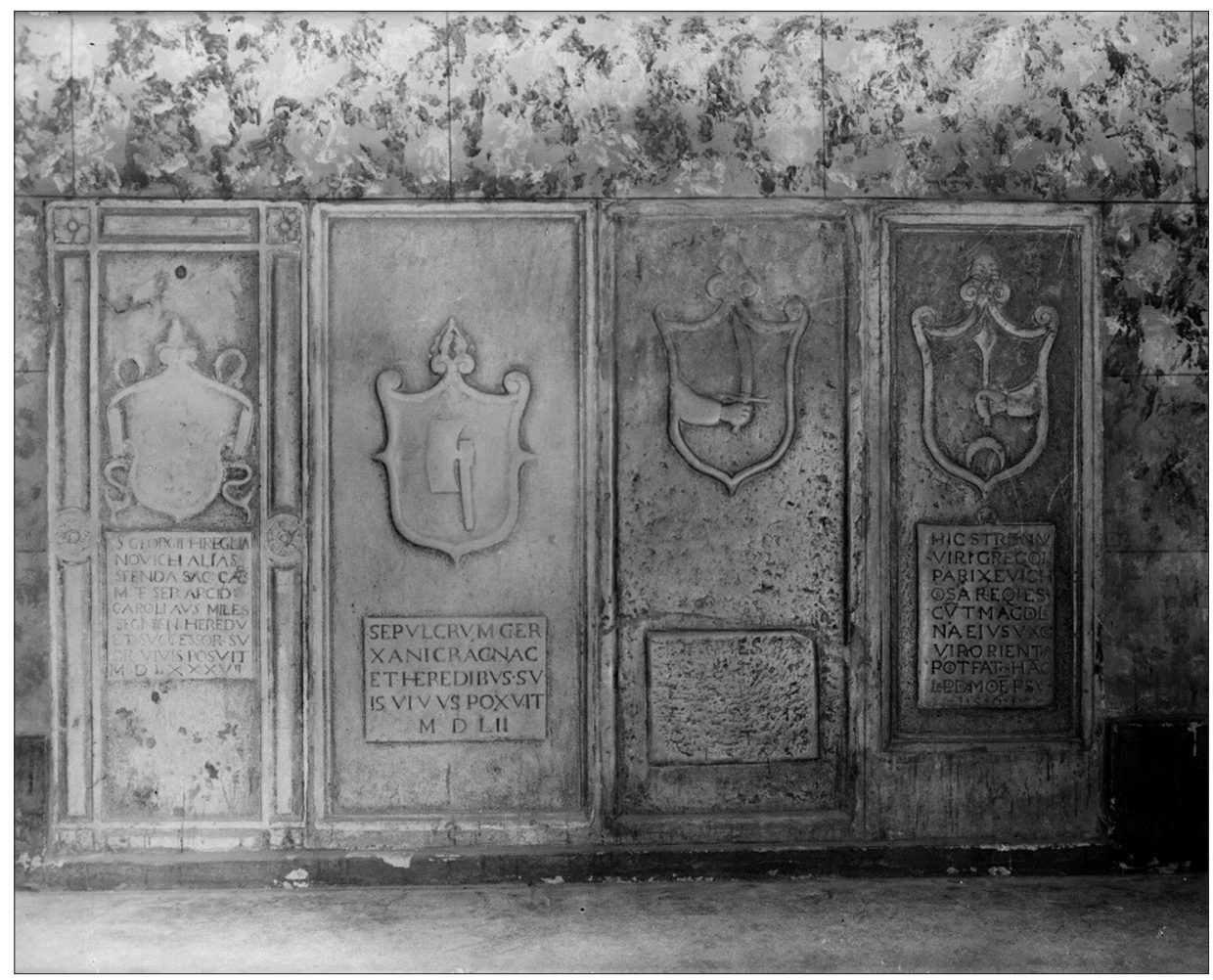

S1. 29. Nadgrobne ploče senjskih gradskih odličnika u crkvi sv. Franje prije rušenja (izvor: fotoarhiv HAZU)

ovu crkvu svečano posvetio (vidi gore natpis). U svetištu na podu lijevo od oltara ima još jedan reljef žene, natpisa nema i to je valjda jedina ploča što je ostala na podu na svom grobu.

Zanimljivo je da je Kukuljević Sakcinski znao za natpis nad grobom Jurja Daničića pa ga je priopćio u svojim Nadpisima ${ }^{241}$ jer da se nalazi u "svetilišću" crkve sv. Franje: "GENEROS. AC STRENS DOMINVS GEORGIVS DANICHICH/ CONTER. CIVITATIS SEGNS CASS.L./ARCIS PROSORS NEC NON S. R. M. EGREGIVS MILES, PROCUMB/DEO ANIMAM, PATRIAE CORPVS. FAMAM AETERNITATI CONSECRARE VOLVIT. PRO SE, SVISQ. HEREDIBVS. FECIT ANNO DOMINI MCCL." Na temelju ove vijesti tražio je Magdić grob Daničićev, ali ga nije našao.

${ }^{241}$ G. SZABO, 1940, 43; I. KUKULJEVIĆ SAKCINSKI, 1891, 254, br. 854. 
Sve su ove ploče u crkvi sv. Franje bile dragocjeni spomenici za povijest grada Senja. Budući da je ova bivša franjevačka crkva bila povezana sa životom grada, s pravom je nazvana "Panteon senjskih uskoka" - posljednje njihovo počivalište. Nažalost, rušilačko njemačko bombardiranje u ratu 1943. godine uništilo je ovu crkvu do temelja i teško oštetilo ploče i natpise od kojih je ostalo tek 20 -ak većih i manjih fragmenata koji se čuvaju u dvorištu župnog ureda.

\section{Arhitektonska snimka crkve sv. Franje iz 1894. godine ${ }^{242}$}

Godine 1894. crkvu sv. Franje arhitektonski je snimio ing. Vjekoslav Horaček koji je tada upravljao i vodio preuređenje vodovoda u Senju te su publicirani: tlocrt, uzdužni i poprečni presjeci te glavno pročelje uz opis i glavne mjere. ${ }^{243}$

Crkva sv. Franje opisuje se kao "romanska bazilika" s tri lađe gdje je srednja lađa proviđena štukatoriranim plafonom, a dvije pobočne gotički svođene. ${ }^{244}$ Također se kaže da je građena u stilu romanske bazilike. ${ }^{245}$ Strop srednje lađe i svetišta je ravan, dok su kapele u pobočnim lađama svođene kao u katedrali ili se navodi: "Crkva je sazidana posve poput stolne, ima ravnim stropom prekritu srednju lađu i po tri kapele u pobočnim lađama, koje su svođene."246 U novije vrijeme izvornu tlocrtnu dispoziciju crkve stručno je prikazao Zorislav Horvat.

Međutim, prema uščuvanim nacrtima iz 1894. godine koji u prosjecima pokazuju naknadno unesene klasicističke profilacije - kao u katedrali te kao u župnim crkvama obližnjih mjesta Novog Vinodola i Bribira - te nakon svih pregradnja i dogradnja u tlocrtu, jasno ukazuje na tipično ranogotičku franjevačku baziliku kojoj je glavna karakteristika da glavna (srednja) lađa svojom cijelom širinom funkcionalno prelazi u dugačko i široko svetište, što odgovara duhu franjevačkog reda kome je težnja što veća povezanost $\mathrm{s}$ vjernicima. ${ }^{247} \mathrm{~S}$ time se slaže i Damir Demonja koji je na temelju dostupnog materijala analizirao izvornu tlocrtnu dispoziciju crkve. ${ }^{248}$

Gotiku donose u naše krajeve franjevci i dominikanci koji su taj arhitektonski izraz primili u vrijeme njegova postojanja u Italiji. Oni, međutim,

${ }^{242}$ J. CHVALA, 1894, 1-2.

${ }^{243}$ J. CHVALA, 1894, 1-2.

${ }^{244}$ J. CHVALA, 1894, 1.

${ }^{245}$ J. FRANČIŠKOVIĆ, 1931, 414.

${ }^{246}$ G. SZABO, 1940, 42.

${ }^{247}$ M. VILIČIĆ, 1971, 106.

${ }^{248}$ D. DEMONJA, 1998, 23-33. 

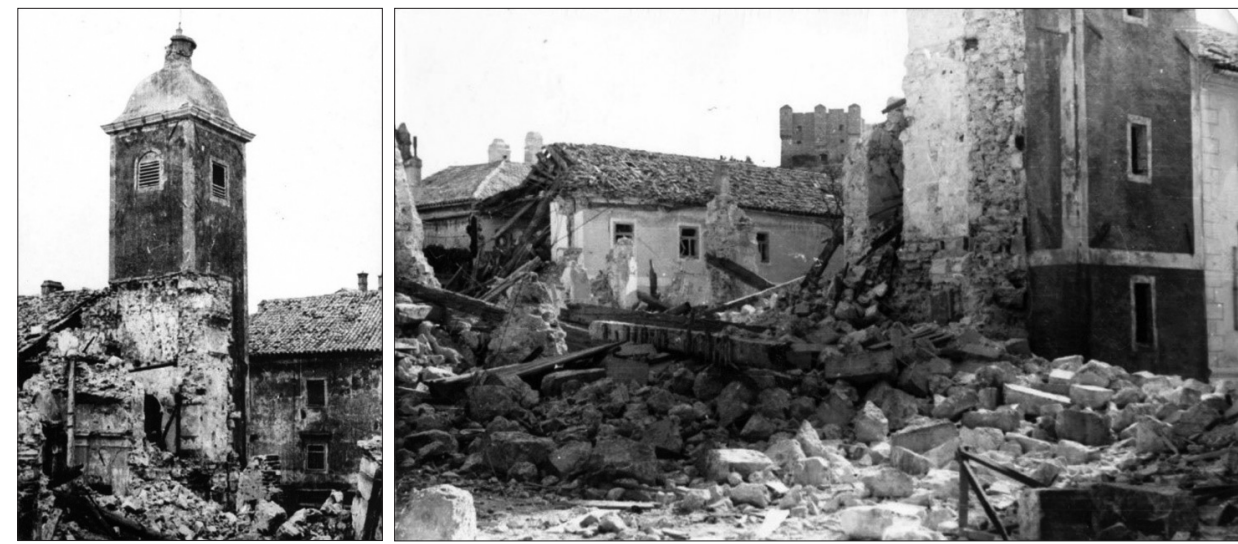

Sl. 30. a) i b) Srušena crkva sv. Franje sa zvonikom,

7. i 8. listopada 1943. godine (izvor: Gradski muzej Senj)

razvijaju njezin posebni tip: grade u prvim njezinim oblicima, uzimaju od gotike samo neke elemente i njih podređuju svojim potrebama naglašavanja asketizma i siromaštva. Zato i svu konstruktivnost gotike primjenjuju vrlo skromno, strop ostavljaju ravan, drven, izbjegavaju svu dekorativnost i redovno izgrađuju prostrane, jednobrodne propovjedničke građevine. Gradnja reprezentativnih zvonika u to je vrijeme zabranjena.

Iako je crkva sv. Franje građena sredinom 16. stoljeća kada je gotiku zamijenio duh renesanse, prostorno je bila oblikovana $u$ duhu tradicije franjevačkih crkava, a ipak s renesansnim portalom. Vjerojatno je toranj kasnije dodan, najprije poput kule - promatračnice - da bi već šezdesetak godina kasnije imao barokni pokrov.

\section{Rušenje crkve sv. Franje}

U Drugom svjetskom ratu, uz mnoge druge objekte, u Senju je porušena i crkva sv. Franje; od nje su ostali samo temelji i napuknut toranj. Godine 1943., nakon kapitulacije Italije, u Senj ulaze partizanske jedinice te on tijekom kratkog vremena do dolaska Nijemaca postaje partizanska luka i središte preko kojeg su uspostavljene pomorske i kopnene veze između Primorja i unutrašnjosti. Zato su Nijemci u dva navrata bombardirali Senj (7. i 8. listopada 1943. godine ). Za kratko vrijeme Senj je pretvoren u ruševine i tom je prilikom do temelja razorena crkva sv. Franje. U prah su pretvoreni oltari, kor, propovjedaonica, dok je inventar gotovo sav uništen. Ostao je neoštećen kip Majke Božje Loretske (koji je sada 
na glavnom oltaru Katedrale). Iz blokova kamenja izvučen je malo oštećen kip Majke Božje Karmelske ili Ribarske koji je restauriran i sada se nalazi također u Katedrali. Na blagdan Gospe Karmelske ribari ga nose u procesiji ulicama grada Senja. U stotine komada uništene su uskočke nadgrobne ploče, od kojih je sačuvano oko 20 fragmenata. Prema obećanju tadašnje Jugoslavenske akademije znanosti i umjetnosti ploče su se trebale po mogućnosti restaurirati.

\section{U kojem smjeru treba ići obnova Sv. Franje? ${ }^{249}$}

Crkva nije poslije rata imala u rukama ni pravnu ni materijalnu mogućnost da obnovi crkvu sv. Franje. Zgrada bivšeg samostana, a od 1806. Biskupskog sjemeništa, bila je nacionalizirana. Budući da je crkva sv. Franje bila značajna i za grad Senj i za hrvatsku povijest, krenule su inicijative izvan crkvenih krugova da na prostoru Sv. Franje ne bude ruševina.

Senjski konzervator Vuk Krajač pokrenuo je inicijativu da se na prostoru bivše crkve sagradi mauzolej senjskih uskoka. Na prijedlog Senjskog muzejskog društva, idejni projekt napravio je kipar i arhitekt Ivan Meštrović. Osnovan je i odbor, ali sve je stalo kada je 1962. godine umro inicijator - Vuk Krajač. Ideju je prihvatio direktor Gradskog muzeja Ante Glavičić koji je uz potporu Senjskog muzejskog društva i Skupštine Općine Senj okupio oko nje više znanstvenika i arhitekata. Općina Senj je to službeno povjerila Gradskom muzeju i Senjskom muzejskom društvu, ali je i imenovala posebni odbor. Ujedno je dr. Melita Viličić dobila zadatak da sa stručnjacima Arhitektonskog fakulteta, a uz suradnju s uvaženim arhitektima, umjetnicima, konzervatorima i muzealcima izradi projektnu dokumentaciju za izgradnju mauzoleja. ${ }^{250}$ Projekt je izrađen 1972. godine, ali su se ispriječile opet brojne prepreke pa do realizacije projekta nije došlo. ${ }^{251}$ Ipak je na kraju te faze restauriran zvonik 1990. godine. ${ }^{252}$

Nakon uspostave samostalne države Hrvatske jasno je bilo da će biti potrebno mnogo toga mijenjati, što će se odraziti i na novo definiranje prostora crkve sv. Franje. Crkvena dimenzija mogla je doći više do izražaja, ali se nije odustajalo od ideje "mauzoleja" jer je ona bila stoljećima povezana s crkvom sv. Franje. Ratne prilike nisu pogodovale nekim većim zahvatima, ali trebalo je s nečim započeti.

${ }^{249}$ Ovaj dio izrađen je prema tekstu B. LJUBOVIĆ, 2015-2016, 391.

${ }^{250}$ M. VILIČIĆ, 1970, 225-240.

${ }^{251}$ A. GLAVIČIĆ, 1970, 205-224.

${ }^{252}$ B. LJUBOVIĆ, 2015-2016, 389. Na zvonik je 1998. godine postavljeno staro zvono s te crkve; na njemu je godina 1521., a čuvalo se na izložbi Sakralne baštine Senj. 
Damir Lukanović, dipl. ing. arh. izradio je još 1991. novi projekt uređenja prostora crkve sv. Franje. Po njemu "Idejni projekt uređenja prostora bivše crkve sv. Franje u Senju, odnosno Arhitektonsko-urbanističko rješenje koje bi prostoru nekadašnje crkve dalo funkciju ovom dijelu grada i oplemenilo ga u cjelini ... poštovala srednjovjekovna jezgra grada, tlocrt nekadašnje crkve sv. Franje, a predviđeno pročelje crkve sadržavalo bi sve elemente prepoznatljivoga simbola crkve - bliske svakom građaninu Senja. Prostor bi bio uređen kao znak sjećanja na uskoke i crkvu sv. Franje, a koji bi mogao imati i višenamjenski karakter. Na tom prostoru mogle bi se služiti i svete mise prigodom određenih crkvenih blagdana, organizirati koncerti, recitali, predstave na otvorenom. Pristup ovom prostoru bi bio kroz nekadašnji ulazni portal, sada kopiju, koji bi bio dio stiliziranog ulaznog prostora crkve. Konturu pročelja činio bi metalni okvir između kojih bi se razapela metalna mreža, koja bi asocirala na raster fuga. Tu bi se nalazili $i$ nekadašnji zidni otvori kao i ploče i stilizirana kopija rozete. Prostor bi od ulica bio odvojen kamenim zidovima visine 0,50 m koji bi slijedio obrise nekadašnjih zidova crkve sv. Franje. Unutar tlocrta do iste visine podigli bi se stupovi, te bi se tu uredio prostor za sjedenje. Prostor između zidova bio bi prekriven kamenim opločenjem, $i$ to u dva nivoa: niži i viši. Na prostor u dijelu nekadašnjeg oltara postavila bi se kamena menza s reljefom iz života uskoka. U jednom dijelu povišenog nivoa mogao bi se postaviti i vječni plamen. Restaurirane nadgrobne ploče mogle bi se postaviti na sadašnji zid do dvorišta nekadašnjeg samostana sv. Franje. Ove eksponate trebalo bi natkriti nadstrešnicom kako bi bili zaštićeni od atmosferilija. Predlaže se također da se postavi nekoliko panoa s tekstovima o postojanju crkve, uskoka i o značenju sadašnjeg prostora za Grad Senj i građane Senja. Poštujući povijesne činjenice ovo idejno rješenje za prostor nekadašnje crkve sv. Franje vratilo bi u život prostor Crkve, sjećanja na uskoke, a prostoru dalo funkciju i oplemenilo jedan dio grada." ${ }^{253}$

Blaženka Ljubović, ravnateljica Gradskog muzeja Senj, ovako zaključuje svoju viziju obnove Sv. Franje: "Nakon svih dosadašnjih inicijativa o uređenju $i$ definiranju prostora razrušene crkve sv. Franje Poglavarstvo Grada Senja pokrenulo je 1995. novu akciju radi rješavanja problematike oko prostora crkve $i$ njezine sačuvane spomeničke građe kako bi se prostor konačno uredio i definirala njegova namjena. Tada je grad Senj izdvojio određena financijska sredstva za inventarizaciju sačuvane spomeničke građe iz razrušene crkve sv. Franje te utvrdilo njezino stanje $i$ brojnost kako bi se mogla nakon obrade ukomponirati u novo i konačno rješenje uređenja cjelokupnog crkvenog prostora. Na tu temu su

${ }^{253}$ B. LJUBOVIĆ, 2015-2016, 389-390. 

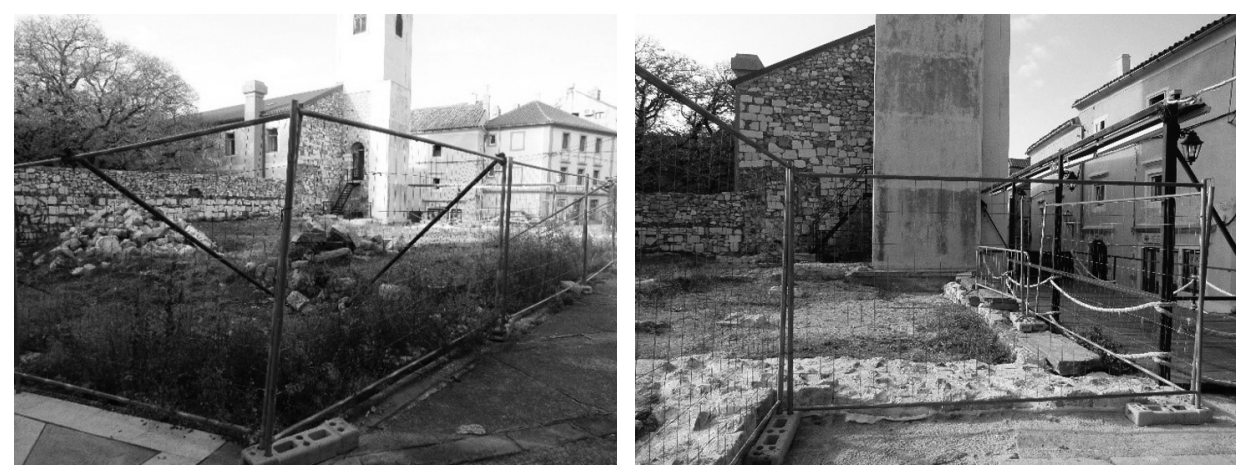

S1. 31. a) i b) Lokalitet crkve sv. Franje, 2020. (foto: B. Ljubović)

bili i razgovori sa Crkvom odnosno tadašnjom Riječko-senjskom nadbiskupijom. I danas postoji interes za uređenje i konačno definiranje cjelokupnog prostora nekadašnje crkve sv. Franje, svakako uz dozvolu i sugestiju Crkve, tj. današnje Gospićko-senjske biskupije u koji bi se ukomponirali i ostatci grobnih ploča. Taj interes uza Župu Senj, Gradski muzej Senj i Grad Senj pokazuju i senjski građani i svekolika javnost kojojje pri srcu ovaj prostor nekadašnje crkve sv. Franje, simbola grada Senja. U ovom posljednjem pokušaju uređenja prostora razmišljalo se da bi to bilo moguće prema već spomenutom idejnom rješenju D. Lukanovića."254

Ovaj dio donijeli smo opširnije jer sve navedeno stoji pred nama kao zadatak.

\section{c) Dominikanci}

Početkom 13. stoljeća nastali su u Crkvi tzv. prosjački redovi koji nisu prihvaćali samo osobno siromaštvo, već i kolektivno - red je kao zajednica prihvatio siromaštvo, za razliku od benediktinaca koji su osobno bili siromašni, ali je red mogao imati veliku imovinu. Po prilici, stoljeće nakon franjevaca dolazi u Senj i drugi prosjački red - dominikanci. U Senju se prvi put dominikanci spominju 1378. godine kada su od biskupa Portive i Senjskog kaptola dobili crkvu ili kapelu sv. Nikole ${ }^{255}$ i na tom prostoru napravili samostan i veću crkvu posvećenu istom svecu - sv. Nikoli. Sa strane dominikanaca crkvu su primili

${ }^{254}$ B. LJUBOVIĆ, 2015-2016, 390-391.

${ }^{255}$ CD XV, 365-371; CD XVI, 70-71; CD XVII, 380. O dominikancima u Senju v. P. TIJAN, 1937, 67-71; S. KRASIĆ, 1971, 293-309; S. KRASIĆ, 1974-1975, 157-246; S. KRASIĆ, 1979, 201-321; F. ŠANJEK, 2008.

${ }^{256}$ CD XVI, 70-71. 
predstavnici dalmatinske vikarije koja je 1380. godine postala samostalna Provincija Dalmacija. ${ }^{256}$

Dominikanski red podijeljen je na provincije. Unutar pojedinih provincija postojale su uže zajednice samostana koje su se zvale congregatio ili natio. Senjski samostan nalazio se unutar provincije Dalmacije, koja se protezala duž jadranske obale od Istre do Drača. Kada je većina toga područja potpala pod mletačku vlast, samostani na području Dubrovačke Republike uspjeli su se osamostaliti i osnovati 1486. godine samostalnu dominikansku kongregaciju koja je ovisila izravno o središnjoj upravi u Rimu. Sjeverni dio provincije Dalmacije koji nije bio pod mletačkom vlasti želio je također postići takvu samostalnost. Inicijativu je preuzeo senjski samostan sv. Nikole, a pridružiše mu se samostani sv. Antuna opata u Modrušu i sv. Ante u Bihaću. Trebalo je dugo raditi i na koncu je 1508. godine središnja vlast u Rimu uspostavila samostalnu kongregaciju sa središtem u Senju, uz dva već spomenuta samostana u Modrušu i Bǐšć (Bihaću). Zajednica tih samostana u spisima se naziva "senjska nacija" (natio segniensis), "hrvatska kongregacija" (Congregatio Croatiae), a katkada je nosila jedan i drugi naziv (Congregatio Segniae et Croatiae).

Kongregacija je zaživjela u teška vremena, a još su bila teža pred njom. Turci su napredovali rušeći i paleći, narod je stradavao, a stradaše i mnoge državne i crkvene ustanove. Nastradaše i samostani. Modruški se spominje zadnji put 1513. godine. Nije isključeno da su se neki dominikanci dali na put prema primorju, kao što je učinio modruški biskup 1493. godine. Ime Kongregacije zadnji put se spominje u spisima 1587. godine, a Krasić misli da je zakoračila i u 17. stoljeće. Najduže se držao senjski samostan, ali ni on nije izdržao. Iako je samostan dobivao neku potporu od vojne uprave u Senju, pomoć je bila premala za uzdržavanje crkve i samostana. Biskup Markantun de Dominis u izvješću Ad limina 1602. godine kaže da samostan više liči na gostinjac nego na samostan; u njemu žive dva-tri redovnika bez ikakvog pravila i reda. ${ }^{257}$ Samostan je bio prije 1614. godine pripojen štajersko-koruškoj provinciji, u kojoj su glavnu riječ imali Austrijanci. Dominisov nasljednik Martena piše u prosincu 1615. godine da su u samostanu dva redovnika koji primaju od državne vlasti mjesečno 4 forinta. ${ }^{258}$ Nova uprava nije naročitu pažnju pokazala prema senjskom samostanu što je svakako pridonijelo da je on napušten. Senjski samostan, pod zaštitom nesavladivog Nehaja, nije napunio ni dva desetljeća u 17. stoljeću. Nekoliko redovnika jednostavno ga je napustilo. Godine 1634. u samostan su se uselili pavlini.

${ }^{257}$ M. BOGOVIĆ, 2003, 118.

${ }^{258}$ M. BOGOVIĆ, 2003, 127. 
Iako nakon radova Stjepana Krasića o senjskoj ili hrvatskoj kongregaciji znamo više, ipak je sve to skupa jako malo. Poznato nam je da su i kod nas bili dominikanci vrsni propovjednici. Za neke imamo podataka da su vršili i druge službe. Spomenut ću njih nekoliko koji su iz Senja ili su radom vezani uz Senj. Prvi vikar senjske "nacije" bio je Dubrovčanin Donat Đorđić. Prethodno je bio provincijal dalmatinske provincije, a poslije je imenovan trebinjsko-mrkanskim biskupom. Nikola iz Senja je 1395. godine počeo poučavati na školama u Lombardiji. Ivan Blažev iz Senja imao je slobodu kretanja po svim samostanima, a mogao je boraviti i izvan samostana jer se bavio arte lignaminis. General reda daje mu 1476. godine pravo da za svoj rad može osobno primati novac. Budući da se kreće po raznim krajevima, skloni smo vjerovati da se ne radi o običnom zanatliji, već o umjetniku u drvu. Matični samostan mu je u Senju, ali se kreće i po Italiji. Dominik iz Senja, nakon što je završio studij u Italiji, bio je neko vrijeme magister u Zadarskom generalnom studiju (studium generale), na koju službu ga je general reda imenovao 1495. godine.

\section{d) Pavlini}

Isprave pavlinskih samostana nalaze se danas u Hrvatskom državnom arhivu pod nazivom Pavlinski samostani. Tu su isprave Sv. Spasa (1261.) i Sv. Jelene (1252.). Popisao ih Josip Barbarić u članku Građa za povijest Krbavske biskupije u Arhivu Hrvatske. ${ }^{259} \mathrm{O}$ pavlinskom redu kod nas imamo dosta dobrih članaka, no ipak jednu sveobuhvatnu monografiju još uvijek očekujemo. Najviše je u tom smislu učinio Kamilo Dočkal, ali on svoje djelo nije doradio do objavljivanja pa ono sada služi kao prijeko potrebna pomoć svakome koji se bavi poviješću pavlina kod nas. ${ }^{260}$ I o pavlinima u Senju mnogi su pisali, ali više onako

${ }^{259}$ Krbavska biskupija u srednjem vijeku, 1988, 262-266.

${ }^{260}$ Kamilo DOČKAL, Građa za povijest pavlinskih samostana u Hrvatskoj. Rukopis u Arhivu HAZU pod sign. XVI 29a. Isprave Sv. Spasa su XVIa (3), a Sv. Jelene XVIa (5). Jedan je primjerak rukopisa u Metropolitanskom arhivu u Zagrebu. Dorađeniji je onaj prvi.

${ }^{261}$ Najviše ćemo materijala naći kod Daniela Farlatija: Illyricum sacrum, IV i često citiranoj knjizi Manojla Sladovića. Potrebno je svakako konzultirati pisce povijesti Senja Milu Magdića (u prvom redu njegovu knjigu Topografija i povijest grada Senja, Senj, 1877.), Pavla Tijana, Antu Glavičića. Tijan je napisao više vrijednih članaka. Jedan od njih je: Grad Senj u povijesti i kulturi hrvatskog naroda u zborniku Hrvatski kulturni spomenici 1, Senj, Zagreb, 1940, str 11-34. Nezaobilazan je kao izvor informacija i sažetak senjske prošlosti Vodič po Senju i okolici, Senj 1984, profesora Ante Glavičića. Vrijedne priloge na ovu temu dala je Melita Viličić, pogotovu u djelu: Arhitektonski spomenici Senja, Rad JAZU, Knjiga 360, Zagreb, 1971.

${ }^{262}$ M. BOLONIĆ, 1973. O senjskim pavlinima v. str. 274-286. 
usput, u okviru širih tema ${ }^{261}$, tako da ni o senjskim pavlinima nemamo temeljiti prikaz. Najpotpuniji pregled dosadašnjih pisanja dao je Mihovil Bolonić262, tako da smo dobili jednu cjelovitiju sliku. Premda je Bolonićev članak i više od pregleda, ipak ni tu nisu iskorišteni svi objavljeni izvori ${ }^{263}$, a kamoli da su upotrijebljeni svi danas lako dostupni radovi. ${ }^{264}$ To je razumljivo jer ni Bolonić niti koji drugi znanstveni radnik nije do danas uzeo sebi kao glavni zadatak prikazati povijest senjskih pavlina. Ovaj prikaz, dakako, nema pretenzije da tako nešto ponudi, nego prvenstveno da pokupi i složi u logičnu cjelinu sve ono što je do danas o senjskim pavlinima rečeno.

Kao što je poznato, na početku 13. stoljeća nastaju dvije redovničke zajednice koje su se ubrzo proširile po čitavoj Katoličkoj Crkvi: franjevci i dominikanci. To je vrijeme kada se kod nas javlja i pavlinski red. Biskup Bartol iz Pečuha 1215. godine organizirao je u prve zajednice ostatke pustinjačkog života u Panoniji, a Euzebije iz Ostrogona utemeljio je red i dao im redovničko pravilo sv. Augustina. Budući da su ti pustinjaci nastojali u svom životu nasljedovati sv. Pavla iz Tebe, prvog pustinjaka, nazvani su pavlinima. U istom stoljeću proširili su se na područje Zagrebačke biskupije: Dubica (1244.), Remete (1278.) i Garić (1295.). Samostani su se neprestano umnožavali. U biskupije Senjsku i Krbavsku dolaze pavlini sredinom 14. stoljeća. Najpoznatiji samostan u ovom kraju bio je onaj sv. Nikole u Modruškom gvozdu (šumi) gdje je u 14. i 15. stoljeću bilo sjedište gvozdanske ili primorsko-istarske vikarije. Po prilici u isto vrijeme kada je samostan sv. Nikole, nastaje i samostan Sv. Spasa u uvali Ljubotina s južne strane Senja. Godine 1390. osnovan je samostan sv. Jelene u Vlaškoj dragi, sa sjeverne strane Senja. Inače je u duhu pavlinskog reda da ne osnivaju samostane u gradovima (jer su nastali kao pustinjaci), nego na osami,

${ }^{263}$ Malyusz Elmer objavio je još 1925. godine u časopisu Leveltdri közlemenyek", br. III, članak: A szlavoniai es horvätorszagi közepköri palos kolostrok oklevelei az Orsz. leveletarban. $\mathrm{Tu}$ su, među ostalim, regesti isprava pavlinskih samostana sv. Jelene kod Senja (svega 15 regesta, str. 181-185) i Sv. Spasa kod Senja (19 regesta, str. 185-194). Isprave su objavljene u cijelosti do uključivo godine 1399. u Diplomatičkom zborniku (CD). Bolonić stavlja prvi spomen Sv. Spasa u godinu 1375., a u CD XIII, 399-401 taj samostan izričito se spominje 24. rujna 1364. godine.

${ }^{264} \mathrm{Tu}$ u prvom redu mislim na zbirku isprava pojedinih samostana koja se danas (od 1958. godine) nalazi u Hrvatskom državnom arhivu u Zagrebu, u fondu Pavlinski samostani. Fascikl samostana Sv. Spasa sadrži 30 isprava, od kojih je samo 6 objavljeno u CD. Četrnaest isprava o tom samostanu objavio je Đuro Šurmin u knjizi: Hrvatski spomenici, Zagreb, 1898. Od 14 isprava samostana sv. Jelene, koje se nalaze u tom fondu, u CD objavljena je samo ona najstarija (iz 1390. godine), a Šurmin je od toga objavio samo 4 isprave, one koje su pisane glagoljicom. Pored toga u, Arhivu JAZU (HAZU) nalaze se 4 srednjovjekovne povelje koje se odnose na samostan Sv. Spasa (DV I, 111, 119, 135; DV XV, 11-12). 
ali uz putove na mjestima gdje su putnici bili najjače ugroženi. Primjeri tih triju samostana to jasno pokazuju. Za samostane Sv. Spasa i sv. Jelene dokumenti s kraja 15. stoljeća govore da se nalaze "na brigu mora". ${ }^{265}$ Ovdje riječ "brig" znači obala kraj vode. Ako se u počecima tih dvaju samostana ne primjećuje frankopanska ruka, ipak ih s pravom i Vjekoslav Klaić i Mihovil Bolonić ubrajaju u frankopanske zadužbine jer su Frankopani bili u vrijeme njihova života najsigurniji i najizdašniji zaštitnici. ${ }^{266}$ To ipak vrijedi više za samostan sv. Jelene, nego onaj Sv. Spasa.

U samom Senju pavlini dobivaju samostan i crkvu tek u novom vijeku (1634. godine), kada je već dobrano izblijedio prvotni duh reda. U Senju su oni ostali sve do 1786. godine, kada je odlukom previšnjeg cara Josipa II. red bio ukinut na području cijele Habsburške Monarhije. Sačuvao se samo u krajevima nad kojima svemoćni car nije imao vlast (Poljska). Vrijedno je da se tih bijelih otaca sjetimo jer su tragovi njihova rada veoma uočljivi u povijesnom razvoju Senja.

Već smo spomenuli da su pavlini imali svoje samostane na osami, ali su posjedovali također neke kuće u gradu Senju. Kuće u Senju imaju ne samo obližnji samostani Sv. Spasa ${ }^{267}$ i sv. Jelene ${ }^{268}$, nego i onaj udaljeniji sv. Nikole u Gvozdu kraj Modruša. ${ }^{269}$ Iz nakana darovatelja možemo donekle vidjeti što je ondašnje društvo očekivalo od pavlina. Oni bogatiji najčešće obdaruju pavline da im ovi za uzvrat služe mise i da se za darovatelja mole. Oni siromašniji traže neku protuuslugu. Senjski građanin Julijan de Lucha obdaruje 1415. godine samostan sv. Jelene uz uvjet da tamošnji pavlini vode brigu za uzdržavanje dviju djevojaka ako one ostanu neudane. ${ }^{270}$ Drugi građanin daruje istom samostanu posjede u Senju, ali zauzvrat traži da na istom mjestu u gradu pavlini sagrade kuću u kojoj će doživotno uzdržavati njega i njegovu ženu. ${ }^{271}$

${ }^{265}$ Vidi: I. KUKULJEVIĆ SAKCINSKI, 1863, 159-160; Đ. ŠURMIN, 1898, 384-387; Hrvatske glagoljične i ćirilične isprave iz zbirke Stjepana Ivšića 1100. - 1527., Acta croaticaHrvatski spomenici, 2017, 330-332.

${ }^{266}$ M. BOLONIĆ, 1973, 274-286.

${ }^{267}$ Godine 1449. kupuje taj samostan za 70 dukata dvije kuće u Senju i za 150 dukata kuću s apotekom u istom gradu. (Hrvatski državni arhiv, Pavlinski samostani, Conventus S. Salvatoris br. 13) Godine 1503. Juraj Bisernjaković daruje samostanu jednu kuću u Senju (K. DOČKAL, br. 22).

${ }^{268}$ Godine 1433. senjski građanin Matija Čudinić daruje pavlinima Sv. Jelene posjed u Senju. (Hrvatski državni arhiv, Pavlinski samostani, Conv. S. Helenae, br. 3).

${ }^{269}$ Godine 1406. oporukom senjskog građanina Jurja Draganovića samostan sv. Nikole dobiva jednu kuću u Senju. (Hrvatski državni arhiv, Pavlinski samostani, Conv. B. Nicolai de nemore Modrussiensi, br. 1).

${ }^{270}$ Hrvatski državni arhiv, Pavlinski samostani, Conv. S. Helenae, br. 2

${ }^{271}$ Hrvatski državni arhiv, Pavlinski samostani, Conv. S. Helenae, br. 3. 
Vjerujemo da nije tek slučajno da se u relativno malom broju sačuvanih darovnica na više mjesta spominje apoteka. Tako 1449. godine samostan Sv. Spasa kupuje u Senju kuću s apotekom. ${ }^{272}$ Malo poslije toga, točnije 1453. godine, Tomo, sin pokojnog Ludovika, prodaje u Senju dvije kuće s apotekama samostanu Sv. Spasa. ${ }^{273}$ I samostan sv. Nikole u Gvozdu spominje se u istom kontekstu. Naime, godine 1450. godine senjski apotekar magistar Franjo de Fulgineo vraća samostanu sv. Nikole posjed u Senju. ${ }^{274}$ Dakako da riječ "apoteka" ne treba uvijek uzeti u onom značenju koje ona danas ima jer se ta ista riječ upotrebljavala također za spremište i radionicu, ali i za dućan ili trgovinu u kojoj se moglo sve kupiti - pa i lijekovi. U zadnjem od navedenih slučajeva doista je riječ o ljekarniku, ali se ne spominje da on prodaje svoju radnju (apoteku). U najmanju ruku možemo zaključiti da su pavlini imali u Senju neke radionice i dućane, a možda je neki od njih bio i ljekarnik. Tim su se, naime, poslom pavlini sigurno bavili jer su imali samostane na osami na mjestima gdje je putnik bio najugroženiji.

Nigdje se u srednjem vijeku izričito ne spominje prosvjetna uloga pavlina u Senju. No, nema sumnje da su se i kod nas pavlini tom djelatnosti bavili, ali dokumenti o tome nisu sačuvani. Sačuvani su oni kojima se trebalo dokazivati pravo na neki posjed ili povlasticu. Njihovi posjedi nisu bili uvijek uz samostan, što znači da su udaljenu zemlju iznajmljivali i iz toga imali prihode. To vrijedi još više za kuće. Jedan i drugi samostan imali su kuće i u gradu Senju, a Sv. Spas je imao uz to i stalne zemlje, vrtove i vinograde kraj Baške gdje su poslije dobili i crkvu sv. Kuzme i Damjana. Iz onoga što nam je sačuvano možemo naslutiti da su oni uz čisto vjersku djelatnost razvijali također, zdravstvenu i šire socijalnu djelatnost.

Samostani Sv. Spasa i sv. Jelene bili su glagoljaški o čemu imamo potvrdu iz 15. stoljeća. Za Sv. Spas znamo da je za njega pisao glagoljski misal fra Juraj iz Modruša, inače dugogodišnji prior samostana. To je jasan znak visoke naobrazbe njegova samostana. Drugi podatak nam govori da je za Sv. Jelenu pisan brevijar Illirico $10 .{ }^{275}$

Oba samostana, Sv. Spasa i sv. Jelene, nestadoše u 16. stoljeću. Kada je moglo preživjeti samo ono što je našlo mjesta unutar gradskih zidina, za pavline se nije našlo mjesta u Senju. Samostan sv. Jelene izgubio je materijalnu podlogu

\footnotetext{
${ }^{272}$ Hrvatski državni arhiv, Pavlinski samostani, Conv. S. Salvatoris, br. 13.

${ }^{273}$ Hrvatski državni arhiv, Pavlinski samostani, Conv. S. Salvatoris, br. 15.

${ }^{274}$ Hrvatski državni arhiv, Pavlinski samostani, Conv. B. Nicolai de nemore Modrussiensi, br. 4.

${ }^{275}$ M. BOGOVIĆ, 2019, 90.
} 
jer mu je većina posjeda bila izložena turskim napadima i pljačkama. Samostan Sv. Spasa bio je pod tim vidom u boljem položaju jer je uz posjede u Senju imao kudikamo na sigurnijem one u Bašćanskoj Dragi koja je pod Mletačkom Republikom. Nemamo razloga sumnjati da su se redovnici upravo tamo i sklonili pa se tako u spomenutom hospiciju sačuvala navezanost na Senj sve do ponovnog dolaska pavlina godine 1634. godine. Franjevcima je u vrijeme povlačenja osigurano mjesto u gradu. Za njih su se zauzeli Frankopani i hrvatski ban pa čak i sam papa Pavao III. ${ }^{276}$ Jedan od razloga za tu prednost pred pavlinima franjevci su imali u činjenici da su mnogi članovi frankopanske obitelji bili pokopani u prijašnjoj franjevačkoj crkvi. I doista su ostaci tih pokojnika poslije pohranjeni u franjevačkoj crkvi koja je bila sagrađena unutar gradskih zidina. Sredinom 16. stoljeća još uvijek se spominju redovnici samostana Sv. Spasa u Senju. Godine 1549. iznajmljuju oni jednu kuću u Senju Franji Čubraniću. ${ }^{277}$ Jedna pavlinska kuća u Senju spominje se 1626. godine. ${ }^{278}$ Nakon ponovnog dolaska u Senj 1634. godine prior prodaje jednu kuću koju su pavlini posjedovali u gradu, što znači da je neka veza između toga reda i Senja postojala sve tamo od osnutka Sv. Spasa.

${ }^{276}$ Godine 1547. papa Pavao III. potvrđuje naredbu cara Ferdinanda da se franjevcima dade prostor unutar gradskih zidina (M. SLADOVIĆ, 1856, 234-235) Još u rujnu 1540. godine Juraj, Vuk i Nikola Frankopan, kojima se pridružio i Stjepan Blagaj, žale se Ferdinandu što je senjski kapetan Ivan Lenković dao porušiti franjevački samostan i crkvu izvan gradskih zidina, a kosti pokojnika iz frankopanske obitelji, koji su u crkvi bili sahranjeni, da stoje iskopane i razbacane naokolo. Mole da franjevci dobiju crkvu u gradu i da se u nju pokopaju ostaci njihovih predaka (E. LASZOWSKI, MH, III, 1917, 11-13). Dana 24. listopada iste godine Ferdinand odgovara da je franjevcima dodijeljeno mjesto u gradu gdje je prije bila kapelica Sv. Duha. Tamo će franjevci sagraditi sebi samostan i crkvu (LASZOWSKI, MH, III, 1917, 25-26) Papa je 1574. godine potvrdio tu odluku (M. SLADOVIĆ, 1856, 234). Napominjem da se ovdje ne govori o crkvi Sv. Duha pri kojoj se nalazio hospicij, a nalazila se izvan zidina. I ona je bila nastradala i u vrijeme kralja Ljudevita započeta je gradnja u gradu. Senjani 27. lipnja 1549. godine mole kralja za pomoć kako bi se crkva s hospicijem mogla dovršiti u gradu i da siromasi koji su u hospiciju imaju pripomoć jednaku iznosu koji se daje franjevcima (K. DOČKAL, 346-347).

${ }^{277}$ Hrvatski državni arhiv, Pavlinski samostani, Conv. S. Salvatoris, br. 23. Ovo donosimo po rukopisu dr. Josipa Barbarića: Građa za povijest krbavske biskupije u Arhivu Hrvatske (referat na simpoziju o Krbavskoj biskupiji u srednjem vijeku, Rijeka, 1985, str. 27. Napomena - to je objavljeno: Josip BARBARIĆ, Građa za povijest Krbavske biskupije u Arhivu Hrvatske, u: Krbavska biskupija u srednjem vijeku (Zbornik radova znanstvenog simpozija u povodu 800. obljetnice osnutka krbavske biskupije, održanom u Rijeci od 23. do 24. travnja 1986. godine), Rijeka - Zagreb, Visoka bogoslovska škola u Rijeci i "Kršćanska sadašnjost", 1988, 247-270. Kamilo Dočkal samostanu sv. Nikole posvećuje 40 stranica.

${ }^{278}$ Hrvatski državni arhiv, Pavlinski samostani, Razni samostani. Tu se u popisu povelja Sv. Spasa pod br. 25 nalazi opširan regest darovnica. 
Dakako da se od 1634. godine, kada su pavlini dobili samostan i crkvu sv. Nikole u Senju, njihova nazočnost i djelatnost kudikamo jače osjećala.

Kada je 1734. godine, prigodom stogodišnjice dolaska pavlina u Senj, prikazana predstava o Genovevi, među glumcima (i gimnazijalcima) nalazimo desetoricu s prezimenom Vukasović. Ta je obitelj doista bila vezana uz pavline i njihovu crkvu. Kamilo Dočkal prenosi mišljenje nekih starijih pavlinskih pisaca da je Filip Vukasović, koji je živio u 18. stoljeću, podigao u crkvi sv. Nikole oltar Gospine Krunice. ${ }^{279}$ Međutim, taj oltar nalazi se u crkvi još 1634. godine, ali valja čitati i poruku predaje. Vjerojatno je Filip Vukasović taj oltar obnovio i uresio. U katedrali, iznad sakristijskih vrata, nalazi se danas grb porodice Vukasovića. To je odmah kraj pavlinskog oltara Gospe Žalosne, što bi moglo uputiti na zajedničko podrijetlo.

Pavlinski samostan u našim stranama ne uživa u novom vijeku onaj ugled koji je imao u srednjem vijeku. Česte su tužbe na redovnike i sa svjetovne i s crkvene strane. U svom izvješću Svetoj Stolici 1741. godine senjski biskup Benzoni predbacuje pavlinima brojne ispade. Za osnivanje senjske gimnazije 1725. godine velike zasluge imao je Benzonijev prethodnik Pohmajević. U gimnaziji je vidio prigodu ne samo da se osposobi mladež za razne civilne službe, nego također da se nadoknadi bar donekle nedostatak sjemeništa i sjemenišne škole jer su od tada svećenički kandidati mogli u pavlinskoj gimnaziji završiti tzv. humaniores. Bez sumnje da je za to povjerenje prema pavlinima utjecala i njihova školska djelatnost u Lepoglavi. To ne znači da je svuda bilo takvo zadovoljstvo s njihovim radom. Benzoni kaže da je bio prisiljen zabraniti svećeničkim kandidatima da pohađaju pavlinsku gimnaziju. ${ }^{280}$

U vrijeme Marije Terezije nisu bili pavlini ni u carskoj milosti. Brojne reforme i na crkvenom polju tražile su temeljito preustrojstvo crkvenih struktura. Svako naseljenije mjesto trebalo je imati svoju crkvu i svoga svećenika. Svećenik je tu ne samo zbog čisto vjerske djelatnosti nego i zbog toga da država preko njega može opismenjavati sve slojeve društva. No, crkve je trebalo izgraditi, a svećenike uzdržavati. Da bi proradile te nove ustanove i službe, bila su potrebna znatna materijalna sredstva. Otkuda ih namaknuti? Dokidanjem starih ustanova koje se ne pokazuju perspektivne u planu prosvjetiteljskog apsolutizma, stvorio se od prodanih dobara vjerozakonski fond iz kojeg su se mogle financirati nove ustanove i službe. U broj nepotrebnih došao je cijeli pavlinski red. Pavlini nisu bili izravno uključeni u rad s narodom (pastoral) pa u duhu prosvjetiteljske

${ }^{279}$ Hrvatski državni arhiv, Pavlinski samostani, Razni samostani, 20-27.

${ }^{280}$ M. BOGOVIĆ, 2003, 177 i 194. 
etike nisu morali više opstojati. Kraljevsko namjesničko vijeće u Budimu uputilo je 14. ožujka 1786. godine dopis senjskom biskupu u kojem mu nabraja razloge za ukidanje pavlinskog reda i način na koji to treba provesti u pojedinim samostanima. Samostanska stega pavlinskog reda u ugarskom kraljevstvu i priključenim zemljama potpuno je opala. Budući da nije potrebno ni preporučljivo daljnje njihovo uzdržavanje, odlučilo je Njegovo Veličanstvo da se spomenuti red u svim carsko-kraljevskim nasljednim državama u potpunosti dokine i da se članovi reda koji su još sposobni za poučavanje u školama ili za dušobrižništvo za to iskoriste, a ostali neka se stave u mirovinu. Ukinuće će se provesti posredstvom kraljevskih povjerenika koji će biti poslani svi u isto vrijeme, tj. 20. tekućeg mjeseca za svako mjesto. Pavlinima koji su već dobili župe neka se doda odgovarajući broj suradnika iz njihova reda, davši im sve prihode koje su prethodno imali od svog samostana. Za sada neka se smatraju kao ekspavlini. Na kraju se upozorava mjesnog biskupa da pošalje izvještaj kako se to sve odvilo u samostanima na području njegove biskupije. Vojna uprava u Karlovcu, pod čiju su nadležnost spadali samostani na Kapeli i u Senju, dodaje 19. ožujka iste godine da će samostan i crkva sv. Nikole u Senju biti sekularizirani, tj. neće ubuduće služiti u crkvene svrhe. ${ }^{281}$ Godine 1869. vojna uprava je pristala da se pavlinska zgrada koristi za školske potrebe. Nakon što su 19. travnja 1873. godine pavlinske zgrade bile oštećene u potresu, planirano je rušenje starih građevina i izgradnja nove školske zgrade. ${ }^{282}$

\section{Samostan Sv. Spasa kod Senja}

Oko tri kilometra južno od Senja, ispod Jadranske magistrale, u sunčanoj uvali Spasovac (bivša draga Ljubotina) još i danas vide se ostaci starog pavlinskog samostana i crkve Sv. Spasa. ${ }^{283}$ Zorislav Horvat kaže da je jedini vidljivi ostatak bivšeg samostana podzid nad strmim stijenama nad morem: "Faktura zida i način slaganja kamena lijep su i kvalitetan rad i očito potječu iz srednjega vijeka. Taj zid podupire terasu, iza koje je nekoliko zgrada. Za jednu od njih - u njoj je danas 'kafić' - da je nekada bila pavlinska crkva. Ni izvana ni iznutra taj se objekt ne

${ }^{281}$ BAS, fasc. V, br. 26. Biskupov izvještaj nisam našao.

${ }^{282}$ BAS, Spisi 1873., br. 2157. Iako je pavlinska imovina oduzeta u korist Vjerozakonskog fonda, neka suglasnost crkvenih vlasti bila je potrebna jer je taj fond trebao koristiti u crkvene svrhe.

${ }^{283}$ Anž Frankopan u darovnici od 5. lipnja 1485. godine naziva crkvu Sv. Spasa crkvom Spasitelja mira (Đ. ŠURMIN, 1898, 385). Mjesto se danas zove Spasovac. To ime posve je istisnulo naziv Ljubotina.

${ }^{284}$ Z. HORVAT, 1999, 131. 


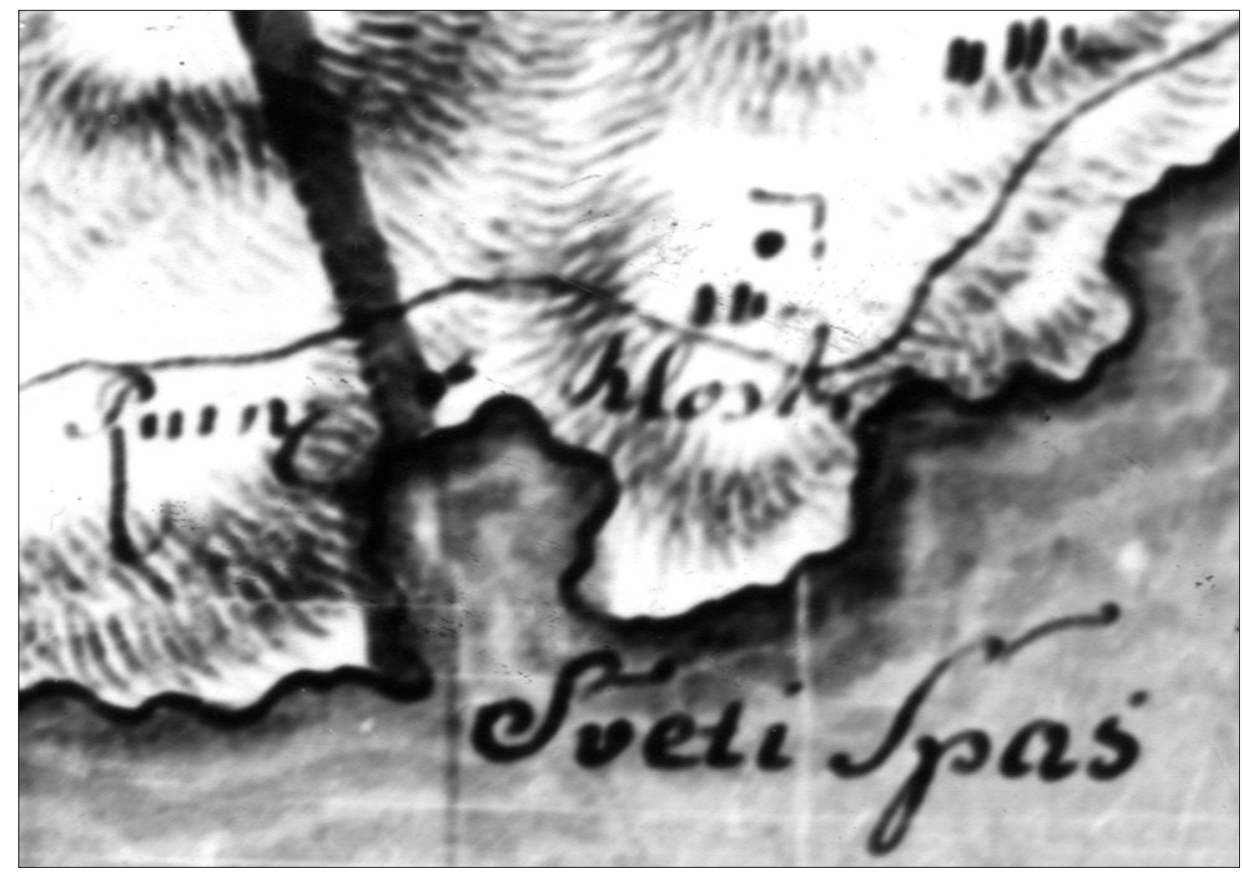

Sl. 32. Sv. Spas prema prikazu Senja iz 1765.

(izvor: Beč, Ratni arhiv: Inl C VII N to)

razlikuje od ostalih stambenih i sličnih građevina u okolici. Općeniti je dojam da pavlinski samostan Sv. Spasa na Ljubotini nije bio velik."

Prva vijest o samostanu Sv. Spasa datira iz 29. rujna 1364. godine. Samostan sv. Nikole u Gvozdu daje u najam spomenutog datuma jednu kuću u Senju Dominiku Ivanovom. Priora toga samostana zastupa prior samostana Sv. Spasa brat Florijan, a s njime je i član toga samostana Urban. ${ }^{285}$ Jasno je da je samostan stariji od prve vijesti koju imamo o njemu.

U darovnici iz 1375. godine navode se podaci koji potvrđuju kojem redu i na kojem se mjestu nalazi samostan. Tu se spominje Jakov "prior samostana Sv.

285 "frater Florianus prior conventus sive monasteri sancti Salvaroris in valle Glubotine prope Segniam" (CD XIII, 399-401). U već spomenutom rukopisu Kamilo Dočkal ovaj samostan obrađuje na 97 stranica. Vidi također: D. FARLATI, 1775, 305-306.

${ }^{286}$ Jakov je "prior monasterii sancti Salvatoris ad Glubotinnam, diecesis Segniensis, ordinis beati Pauli primi heremite" (CD XV, 142). Jakov je prior i 9. kolovoza 1381. godine. (Hrvatske glagoljične i ćirilične isprave iz zbirke Stjepana Ivšića 1100. - 1527., Acta croatica - Hrvatski spomenici, 2017, 33) 
Spasa u Ljubotini, Senjske biskupije, reda blaženoga Pavla prvog pustinjaka". Uz priora je i samostanski brat Juraj. ${ }^{286}$ U vrijeme toga priora, 1377. i 1381. godine, samostan je imao i neke kuće u gradu Senju. ${ }^{287} \mathrm{Za}$ vrijeme priora Krizogona kupljena su dva zemljišta u području Ljubotine, jedno 1387., a drugo 1394. godine. ${ }^{288} \mathrm{U}$ crkvi Sv. Spasa 1399. godine sagrađen je oltar na čast Majke Božje. ${ }^{289} \mathrm{U}$ ispravi od 5. lipnja 1495. godine imamo i neke dodatne precizacije. Anž Frankopan daje pomoć "crikvi Spasitelja mira, ka crikva častno szdana jest na brigu mora v drazi, ka se zove Ljubotina, na južnu stranu Senja". ${ }^{290}$

Na samostan Sv. Spasa kod Senja odnosi se darovnica kneza Žigmunda (Sigismunda) Frankopana - listina izdana u njegovom stolnom mjestu Otočcu 8. svibnja 1452. godine. Ovom darovnicom isti knez daruje pavlinima Sv. Spasa jedno mlinište u Švici. Iz rečene isprave donosimo ovdje sljedeće: "Mi knez Žigmund de Frankopan, knez krčki i modruški i pročaja ... dasmo i darovasmo jedno mesto na Švici, kadi je podobno jedan malin učiniti svetomu Spasu vikuvičnim zakonom. A ti dobri ljudi gospodin vikariš Stanislav od molstira svetago Mikule z Gozda i fratar Filip, priur od svetago Spasa blizu Sena z drage ka se zove Ljubotina sa vsim svoim kuventom ... obećaše ... za zdrave naše i za naše grihe dokle smo živi vsaki misec tri mise peti, a kada bismo mi pomankali, da za našu dušu viku vičnim zakonom imaju obsluževati te tri mise vsaki misec po nih veru i po nih konšenciju." 291

Po smrti kneza Sigismunda (1465.) redovnici samostana Sv. Spasa zajedno s onima sv. Jelene - smatrajući njegovu braću i sinovce baštinicima njegove kneževine - podnose im svima zajedno, sakupljenima na zajedničkom sastanku u Senju, zajedničku molbu kojom ih mole da im potvrde sve njihove posjede koje su im darovali njihovi preci. U vezi s tom njihovom zajedničkom molbom oni izdaju u Senju zajedničku ispravu od 5. ožujka 1466. godine kojom na molbu priora Sv. Jelene Martina i priora Sv. Spasa Jurja potvrđuju darovnice za "2 malina, ki su na Švici, jošće treti malin, ki e svete Jelene v Bočašćeh, v koj malinici sta 2 malina pod Banim dvori s slapi i s potoci, i druge pošešione, a to e sinokošu svete Jelene na Vetrnom dolci, za Knežu goricu; jošće takoe tri ždribi

${ }^{287} \mathrm{CD}$ XV, 141 i 144; CD XVI, 164 i 165.

${ }^{288}$ CD XVII, 118-119, 630-631.

${ }^{289}$ CD XVII, 488.

${ }^{290}$ I. KUKULJEVIĆ SAKCINSKI, 1863, 159-160; Đ. ŠURMIN, 1898, 384-387; Hrvatske glagoljične i ćirilične isprave iz zbirke Stjepana Ivšića 1100. - 1527., Acta croatica - Hrvatski spomenici, 2017, 330-332. U citiranju su, radi lakšeg čitanja, razriješene kratice.

${ }^{291}$ Hrvatske glagoljične i ćirilične isprave iz zbirke Stjepana Ivšića 1100. - 1527., Acta croatica-Hrvatski spomenici, 2017, 133-135. 
zemle v brinskom poli, ko se zove Drščino selo: jošće takoe selo svetoga Spasa Podgvozdaci, ko se zove Šavšće selo, jedan ždribi zemle; jošće takoe pol male vasi $v$ Bočašćeh sa vsim ča $k$ nei pristoi; i takoe $v$ Botocih jedan ždribi zemle velike mere gradske sa v'sim ča k nemu pristoi; jošće takoe jedno selo $v$ Vinodoli, ko e svete Marie na Ospi pod Novim, ko se zove Belgrad." Redovnici će za to moliti za njih i za njihove pokojne. ${ }^{292}$ Isto su učinili knezovi Frankopani sakupljeni 1467. godine u Modrušu, kada ponovno potvrđuju pavlinskim samostanima Sv. Spasa i sv. Jelene kod Senja njihove posjede i njihova prava. ${ }^{293}$

Navodimo i poznatu donaciju knezova Frankopana koji darovnicom od 5. lipnja 1495. godine - izdanom "v našem gradu Brinah" - daruju pavlinskom samostanu Sv. Spasa kod Senja "i na pomoć crikvi Spasitelja mira, ka crikva častno sazdana jest na brigu mora v drazi, ka se zove Ljubotina, na južnu stranu Sena ... va vladanji našem brinskom selo ko se zove Mali Prokičci, sa vsimi seli $i$ ča k nim pristoji, iznimljući van tri ždrebi zemle, ki dani biše od naših prvih crikvi svetoga Spasa poli Sena i svetoj Marii na Crikvenici i svetoj Jeleni poli Sena." Fratri su im dali 90 zlatnih dukata. Fratri će za njih svake nedjelje misiti na čast Svete Trojice, a jedna molitva neka bude za svećenika Tomka Bukvića. ${ }^{294}$ Knez Lacko Kosinjski dao je 1461. godine napraviti oltar za crkvu Sv. Spasa, za što je trebao prodati neke zemlje. Modruški biskup Nikola iz Kotara oslobađa iste godine plaćanje desetine na te zemlje. ${ }^{295}$

${ }^{292}$ I. KUKULJEVIĆ SAKCINSKI, 1863, 98-99; Đ. ŠURMIN, 1898, 247-249; V. KLAIĆ, 1991, 253; Hrvatske glagoljične i ćirilične isprave iz zbirke Stjepana Ivšića 1100. - 1527., Acta croatica - Hrvatski spomenici, 2017, 175-177. Ovdje je i prijevod na latinski (178-179).

${ }^{293}$ Đ. ŠURMIN, 1898, 282. Ovdje je samo regest.

${ }^{294}$ I. KUKULJEVIĆ SAKCINSKI, 1863, 159-160; Đ. ŠURMIN, 1898, 384-387; Hrvatske glagoljične i ćirilične isprave iz zbirke Stjepana Ivšića 1100. - 1527., Acta croatica - Hrvatski spomenici 2017, 330-332. Samostanu sv. Jelene darovano je dvije godine prije selo Košćice, a fratri su dali knezu 300 zlatnih dukata. Ovdje je njihov prilog bio manji pa bi se iz ovoga moglo zaključiti da je ovaj samostan bio siromašniji. Dakako, uzdarje može ovisiti i o većoj vrijednosti dara.

${ }^{295}$ M. SLADOVIĆ, 1856, 143; K. DOČKAL, Sv. Spas, 49. A. GLAVIČIĆ, 1966, 415-416. Ante Glavičić otkrio je u Nehaju ploču slomljenu na dva dijela, on kaže nadvratnicu, na kojoj Ivan i Lacko Kosinjski preporučuju redovnike sv. Pavla. Spominje se i crkva, ali je natpis nejasan u dijelu gdje treba biti ime titulara (A. GLAVIČIĆ, 1981-1982, 87-89). Glavičić je pročitao "Spiritus" (Duh), ali svakako treba čitati "Salvator" (Spas), tim više što je Lacko sagradio oltar u crkvi Sv. Spasa. Najvjerojatnije je ova ploča/nadvratnica iz te crkve. Slično Branko Fučić stavlja pronađeni glagoljski natpis (fra) Šimuna Mećarića na franjevačku crkvu u Senju (B. FUČIĆ, 1982, 320), a franjevci nisu bili glagoljaši. I Šimun bi prije pripadao pavlinima iz Sv. Spasa ili iz Sv. Jelene za koje znamo da su bili glagoljaši. Inače Šimuna nalazimo na dva mjesta da ga se naslovljuje s "pop" prvi put 1478. godine (P. RUNJE, 2007, 128), a drugi put 1488. (Đ. ŠURMIN, 1898, 334; Hrvatske glagoljične i ćirilične isprave iz zbirke Stjepana Ivšića 1100. - 1527., Acta croatica - Hrvatski spomenici, 2017, 275). Tekst na mjestu titule na natpisu je nejasan. 
Kako je razvidno iz gore citirane darovnice kneza Anža Frankopana od 5. lipnja 1495. godine, samostan Sv. Spasa još je uvijek na životu. Isti samostan spominje se među pavlinskim samostanima i u buli pape Julija II. 1504. godine. Prema tome, samostan Sv. Spasa postojao je još svakako početkom 16. stoljeća. Daljnji život samostana i crkve Sv. Spasa nije nam poznat jer nemamo pisanog spomena o njemu. Vjerojatno je i on napušten u prvoj polovici 16. stoljeća zbog turske navale, kao i drugi samostani i crkve izvan senjskih zidina. Sladović misli da je to bilo 1558., tj. kada je sagrađena kula Nehaj. ${ }^{296}$ Melita Viličić kaže da se samostan Sv. Spasa spominje u dokumentu iz 1639. godine u popisu luka: "... 1. Nayprvo porat od Segnia pocamsi Sveti Spas, kadi ye klostar pust fratar svettoga Paula parvoga eremite: onde je porat dobar za brode magnie i vechie." Ruševine samostana urisane su na zemljopisnoj karti iz 1765. godine, odnosno na granici senjskog područja urisana je ruševina u uvali Sveti Spas i uz nju je upisano: Ruine Kloster. To je današnji zaselak Spasovac oko 3 km južno od Senja prema naselju Sv. Juraj. Pavlinski historičar Benger također spominje da su samostani sv. Jelene i Sv. Spasa vjerojatno bili porušeni oko 1558. godine, za vrijeme gradnje tvrđave Nehaj kad je Lenković rušio i ostale samostane izvan gradskih zidina.

Na starim kartama grada Senja iz 18. stoljeća samostan se navodi kao ruševina. Ostaci starog samostana, crkve i gospodarskih zgrada još su i danas vidljivi (3 km južno od Senja niže Jadranske magistrale u sunčanoj uvali nalazi se zaselak Spasovac). Sačuvani su zidovi sa kontraforima, izrađeni od obrađenih kvadara s malterom od kreča i pijeska. Prilikom građevinskih radova i uređenja dvorišta (pred gostionicom) stari zidovi su većim dijelom porušeni. Čini se da je zgrada u koju je sada smještena gostionica stara crkva Sv. Spasa pred kojom su prije rata pronađeni grobovi s ljudskim kostima. Danas je Spasovac posjed Tuge i Miće Krmpotića. ${ }^{297}$ Bivša draga Ljubotina tek u novije vrijeme prozvana je Spasovac po ostacima nekadašnje pavlinske crkve i glagoljaškog samostana sv. Spasa.

Samostan je imao brojne posjede u Bašćanskoj Dragi na susjednom Krku, a 1455. godine dobio je ondje i crkvu sv. Kuzme i Damjana. ${ }^{298}$ Od tada su ondje

296 "Ove godine opuštena i razorena biahu po svoj prilici i vitališta (hospitia) u Sv. Spasu (med Senjom i Sv. Gjurgjem) i Sv. Jeleni, o kojih bula pape Julija II. g. 1504. pominje." (M. SLADOVIĆ, 1856, 236)

${ }^{297}$ A. GLAVIČIĆ, 1966, 415-416.

${ }^{298}$ D. FARLATI, 1775, 305-306. Više o ovom samostanu/hospiciju v. kod M. BOLONIĆ, 1973, 284-286. 


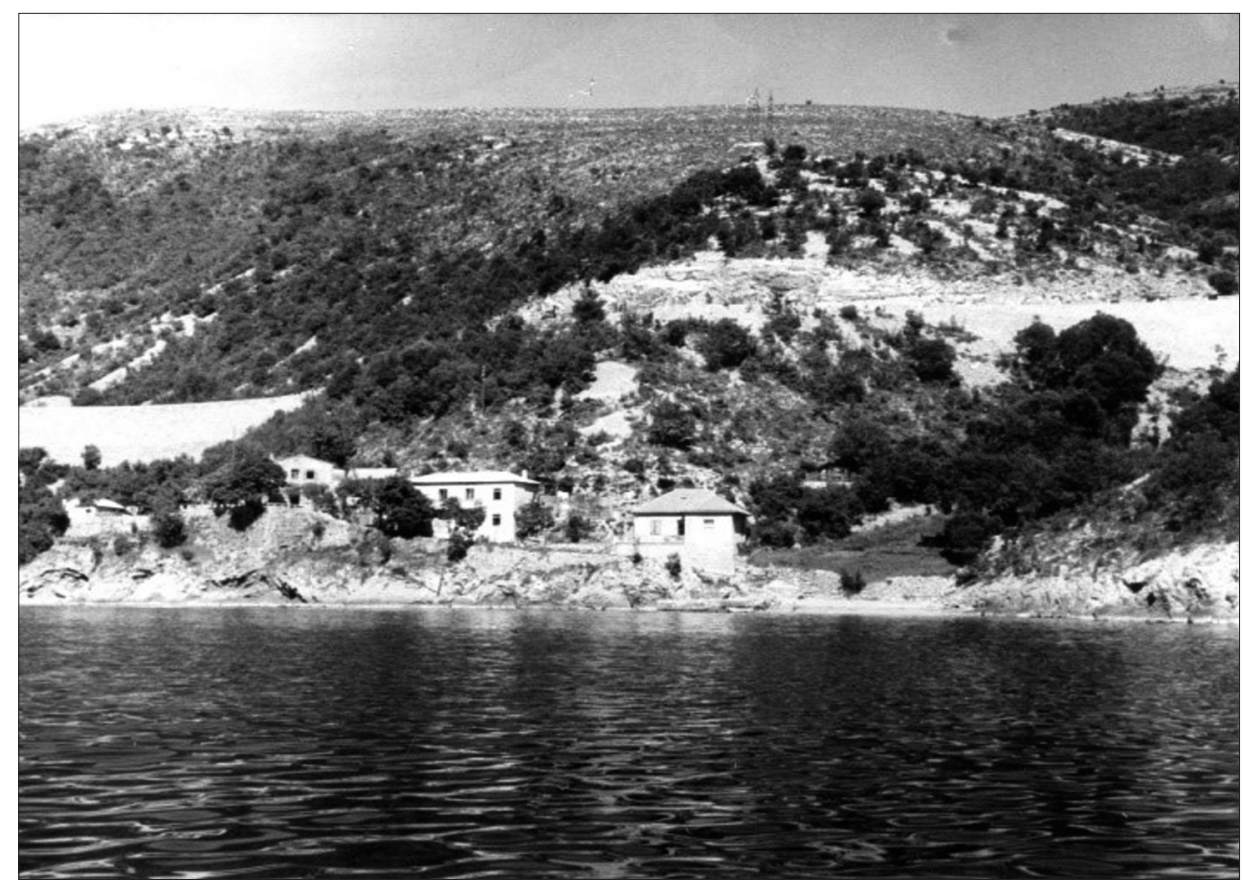

S1. 33. Spasovac kod Senja (nekadašnja Ljubotina), pogled s mora (izvor: Gradski muzej Senj)

postojali samostanski gostinjac (hospicij) koji se katkada spominje kao zasebni samostan, ali je zapravo stalno bio u manjoj ili većoj ovisnosti o samostanu Sv. Spasa. Dapače, kada je ovaj nestao, a 1634. godine osnovan pavlinski samostan sv. Nikole u Senju, gostinjac u Bašćanskoj Dragi bio je ovisan o tom samostanu. Datum darivanja te crkve (20. kolovoza 1455.) pavlinima Sv. Spasa smatra se početkom pavlinskog hospicija u Baški. Prema K. Dočkalu hospicij je 1610. godine pretvoren u samostan. Ova se crkva nalazila na zapadnom kraju uvale zvane Zarok gdje joj se i danas vide posljednji ostaci. Dolaskom Mlečana 1480. godine imali su pavlini ovog hospicija raznih neprilika jer im je matični samostan bio izvan dosega mletačkih vlasti. U vrijeme ukidanja pavlinskog reda (1786.) imovina tog gostinjca tretira se kao imovina Sv. Nikole u Senju. Hospicij je zatvoren negdje oko 1791. godine kad ga je mletačka vlada prodala za 27.000 lira. Tako da je taj samostan/hospicij, premda udaljen od Senja, najjasniji garant pavlinske nazočnosti u Senju sve tamo od 14. stoljeća pa do ukinuća reda. 


\section{Samostan sv. Jelene u Vlaškoj dragi}

Samostan sv. Jelene u Vlaškoj dragi mlađi je od samostana Sv. Spasa. Počeci mu sežu u godinu 1390. kada je senjski arhiđakon Radovan darovao pavlinima crkvu sv. Jelene na tom mjestu. Crkvu je sagradio njegov otac Luka. ${ }^{299}$ Ubrzo je uz crkvu bio sagrađen i samostan. Darovnicu su potvrdili senjski biskupi, najprije Ivan de Cardinalibus (1390.), a poslije njega njegov sinovac Leonardo (1399.). ${ }^{300}$

O sadašnjem stanju piše 1999. godine Zorislav Horvat: "Danas je to ruševina na samoj morskoj obali, obrasla travom i dračem. Najviše je zida sačuvala samostanska crkva. Samostan je bio malih dimenzija i skromne izvedbe, ukupno veličine tlocrta - bez crkve - 21/21 m. Nenatkriveni dio klaustra je 6/10, no nije jasno kako je izgledao natkriveni dio i je li se protezao uokolo (na) sva četiri strane, ili tek djelomično. Debljina samostanskih zidova vrlo je mala. Crkva se nalazi na južnoj strani samostana te ima pravokutno svetište. Zidovi su crkve više oštećeni na južnoj strani, te je očito da je brod bio svođen bačvastim, vjerojatno šiljastim svodom. Ziđe je svetišta nešto manje sačuvano, tako da nema tragova svoda, no na južnom se zidu nekada nalazio omanji neostakljeni prozor. Svetište je postavljeno ekscentrično s obzirom na brod, tako da je oboje prislonjeno uz ravni zid samostana. Te odgovara naknadnoj prigradnji samostana uz crkvu i pojednostavljuje tlocrtno rješenje samostana. Samostan Sv. Jelene je manje površine nego drugi pavlinski samostani." ${ }^{\prime 301}$ Poput pavlinskog samostana Sv. Spasa, tako su knezovi Frankopani obilno dotirali i ovaj samostan sv. Jelene. Među prvim takvim darovnicama u korist samostana sv. Jelene spominje se ona kneza Sigismunda od 11. kolovoza 1444. godine kojom pavlinima Sv. Jelene kod Senja poklanja jedno pusto mlinište na Švici gdje su bila dva njegova mlina, s time da ih poprave i uživaju. Prior samostana je tada fratar Karin. ${ }^{302}$

I drugi sin kneza i bana Nikole IV. "knez Dujam IV. Frankopan krčki i modruški i pročaja", na molbu priora Karina, ispravom od 8. studenog 1445.

${ }^{299} \mathrm{Za}$ izvore i literaturu o ovom samostanu vrijedi ono što je rečeno u bilješci 249. Kamilo Dočkal je ovom samostanu posvetio 54 stranice.

${ }^{300}$ CD XVII, 253-254. Jedna isprava objavljena je kod Lajos THALLÓCZI - Samu BARABÀS, 1910, 342-343. Ni iz jednog dokumenta ne proizlazi da je taj samostan imao posjede na Krku, kako bi htio Bolonić (M. BOLONIĆ, 1973, 279).

${ }^{301}$ Z. HORVAT, 1999, 132-135. Usp. također zbornik Kultura pavlina, 1989, 102-103.

${ }^{302}$ I. KUKULJEVIĆ SAKCINSKI, 1863, 63; Đ. ŠURMIN, 1898, 156-157; Hrvatske glagoljične i ćirilične isprave iz zbirke Stjepana Ivšića 1100. - 1527., Acta croatica - Hrvatski spomenici, 2017, 88. 


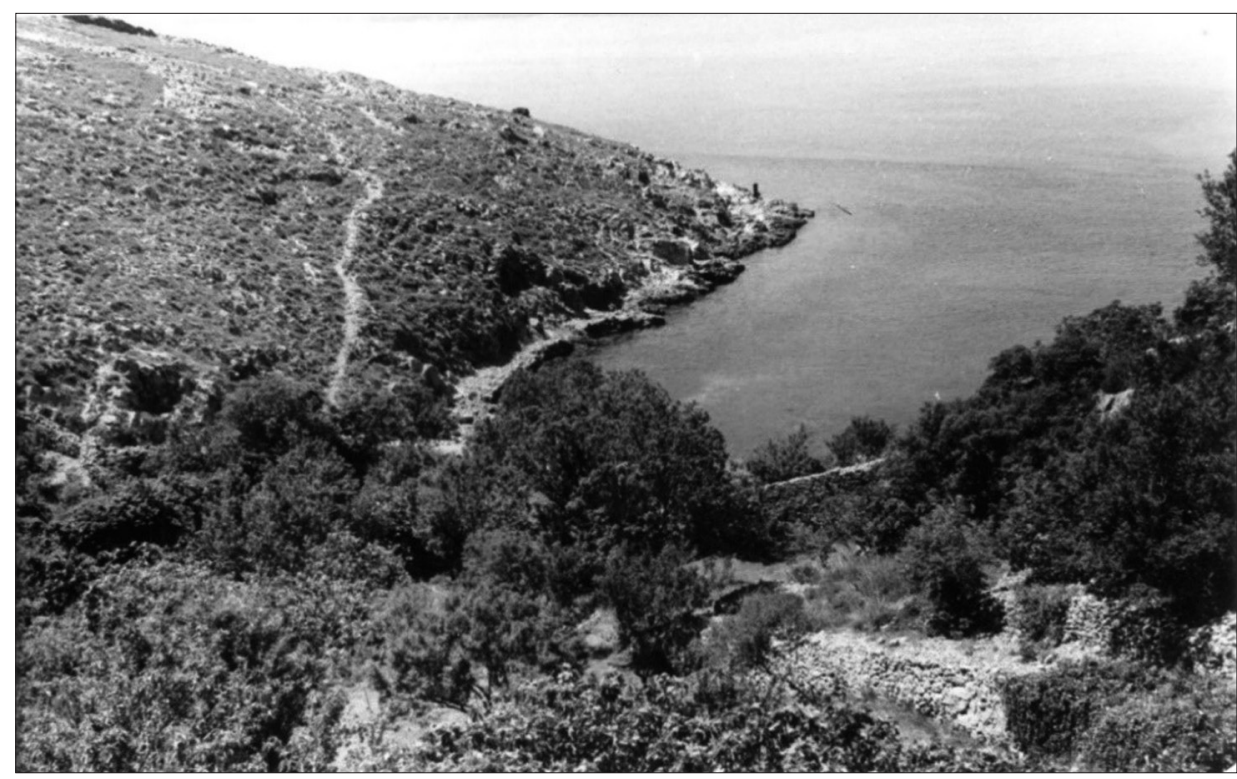

S1. 34. Pogled na lokalitet samostana sv. Jelena - Vlaška draga

(izvor: Gradski muzej Senj)

godine (izdanom u Senju) dozvoljava "fratrom svete Jelene ... dopustismo i darovasmo crkvi Sv. Jelene da možete mliti prez ujamka vekuvečnim zakonom v više rečenih naših malinih." ${ }^{1303}$ Isti knez Dujam izdaje, ponovno u Senju, 17. travnja 1447. godine, i drugu darovnicu kojom daruje "Sv. Jeleni sinokošu onu, ku je držal stari arhižakan Radovan Lukačić ka se zove za kamenim na Čudnići". ${ }^{304}$

I kneginja Elizabeta (Jalža), supruga pokojnog kneza Bartola, svojom darovnicom izdanoj u Jelovici 26. ožujka 1461. godine poklanja samostanu sv. Jelene "Dolac vetrni, ka je pod knežu goricu k Brinam". ${ }^{305} \mathrm{Kad}$ su se braća i sinovci pokojnog kneza Sigismunda (+1465.) sastali u Senju na sastanak, izdali

${ }^{303}$ I. KUKULJEVIĆ SAKCINSKI, 1863, 65; Đ. ŠURMIN, 1898, 160; Hrvatske glagoljične i ćirilične isprave iz zbirke Stjepana Ivšića 1100. - 1527., Acta croatica - Hrvatski spomenici, 2017, 91 .

${ }^{304}$ I. KUKULJEVIĆ SAKCINSKI, 1863, 68; Đ. ŠURMIN, 1898, 169-170; Hrvatske glagoljične i ćirilične isprave iz zbirke Stjepana Ivšića 1100. - 1527., Acta croatica - Hrvatski spomenici, 2017, 95.

${ }^{305}$ I. KUKULJEVIĆ SAKCINSKI, 1863, 90-91; Đ. ŠURMIN, 1898, 237-238; Hrvatske glagoljične i ćirilične isprave iz zbirke Stjepana Ivšića 1100. - 1527., Acta croatica - Hrvatski spomenici, 2017, 166-167. 
su zajedničku ispravu od 5. ožujka 1466. godine kojom samostanima Sv. Spasa i sv. Jelene potvrdiše sve njihove stečene posjede..$^{306}$

Nakon što im je 1469. godine kralj Matijaš oteo Senj, Frankopani su pomagali samostane u Senju i okolini, želeći time također imati u njima saveznike za ponovni povratak u Senj. Knez Martin Frankopan listinom od 15. ožujka 1475. godine - na molbu fratra Filipa "ki biše v to vrime priur svete Jelene" poklanja pavlinima Sv. Jelene kod Senja "edno mesto, kadi učine ednu hišu i edan vrt. Ko mesto ko se imenue ondi kadi e stal Špiranac i e ega brat Repac, a to est poli zeml u crek'vnu". ${ }^{307}$ Kneza Anža fratri su zamolili za pomoć kako bi se i dalje u crkvi sv. Jelene služba Božja mogla primjereno slaviti. Knez Anž uslišava molbu i daruje Sv. Jeleni selo Košćice. Vjerojatno je nešto u crkvi bilo oštećeno. Knez tumači kojim pravom on to čini. Nakon smrti kneza Žigmunda selo je pripalo njegovoj supruzi Jeleni. Ona je dio sela darovala crkvi i samostanu sv. Jelene. Nakon Jelenine smrti selo je došlo u ruke Anžu i njegovoj sestri Barbari. U dogovoru s Barbarom Anž daje cijelo selo crkvi i samostanu sv. Jelene. Selo se nalazi između Marinaca, Kutereva, Krasna i Ljubičića. ${ }^{308}$ Uz to, Anž obećava da će on i njegovi nasljednici štititi i braniti samostan, što znači da se već tada u samostanu osjećala ugroza. Ipak, to nije bilo čisto darovanje jer su fratri Anžu dali 300 zlatnih dukata i obećali da će svaki dan u zoru služiti misu za Anža i za njegove. ${ }^{309}$

Nije poznato što je bilo kasnije sa samostanom i crkvom sv. Jelene kod Senja. Svakako je 1504. godine još postojao jer papa Julije II. u svojoj buli od 5. svibnja 1504. godine, uz ostale pavlinske samostane i onog Sv. Spasa (Sancti

${ }^{306}$ I. KUKULJEVIĆ SAKCINSKI, 1863, 98-99; Đ. ŠURMIN, 1898, 247-249; Hrvatske glagoljične i ćirilične isprave iz zbirke Stjepana Ivšića 1100. - 1527., Acta croatica - Hrvatski spomenici, 2017, 175-177. Samu darovnicu vidi gore kod samostana Sv. Spasa.

${ }^{307}$ I. KUKULJEVIĆ SAKCINSKI, 1863, 113-114; Đ. ŠURMIN, 1898, 275-276; Hrvatske glagoljične i ćirilične isprave iz zbirke Stjepana Ivšića 1100. - 1527., Acta croatica - Hrvatski spomenici, 2017, 1209-1210. To su oni potvrdili ponovno 4. svibnja 1477. godine (samo regest kod Đ. Šurmina, 1898, 282). 62-63)

${ }^{308}$ Stjepan Pavičić opisao je na kojem prostoru bi se to selo prostiralo. (S. PAVIČIĆ, 1962,

${ }^{309} \mathrm{Za}$ isto darivanje imamo dvije originalne povelje koje su u nekim stvarima razlikuju. U drugoj (I. KUKULJEVIĆ SAKCINSKI, 1863, 152-154; Đ. ŠURMIN, 1898, 368 i 370; Hrvatske glagoljične i ćirilične isprave iz zbirke Stjepana Ivšića 1100. - 1527., Acta croatica - Hrvatski spomenici, 2017, 314-316) ne spominje se kneginja Jelena niti se navode granice Košćica. Izgleda da je ova druga napisana kao prva, a nakon intervencija i pritužbi, nastala je ona prva koja detaljnije opisuje odnose i darivanje. U obje povelje dolazi sintagma "dasmo i prodasmo". Izgleda da nije ugrožen samo samostan s crkvom sv. Jelene u Vlaškoj dragi, nego su ugrožena i frankopanska dobra jer se daruje nesigurno (Košćice) da bi se dobilo sigurno (300 zlatnih dukata). 


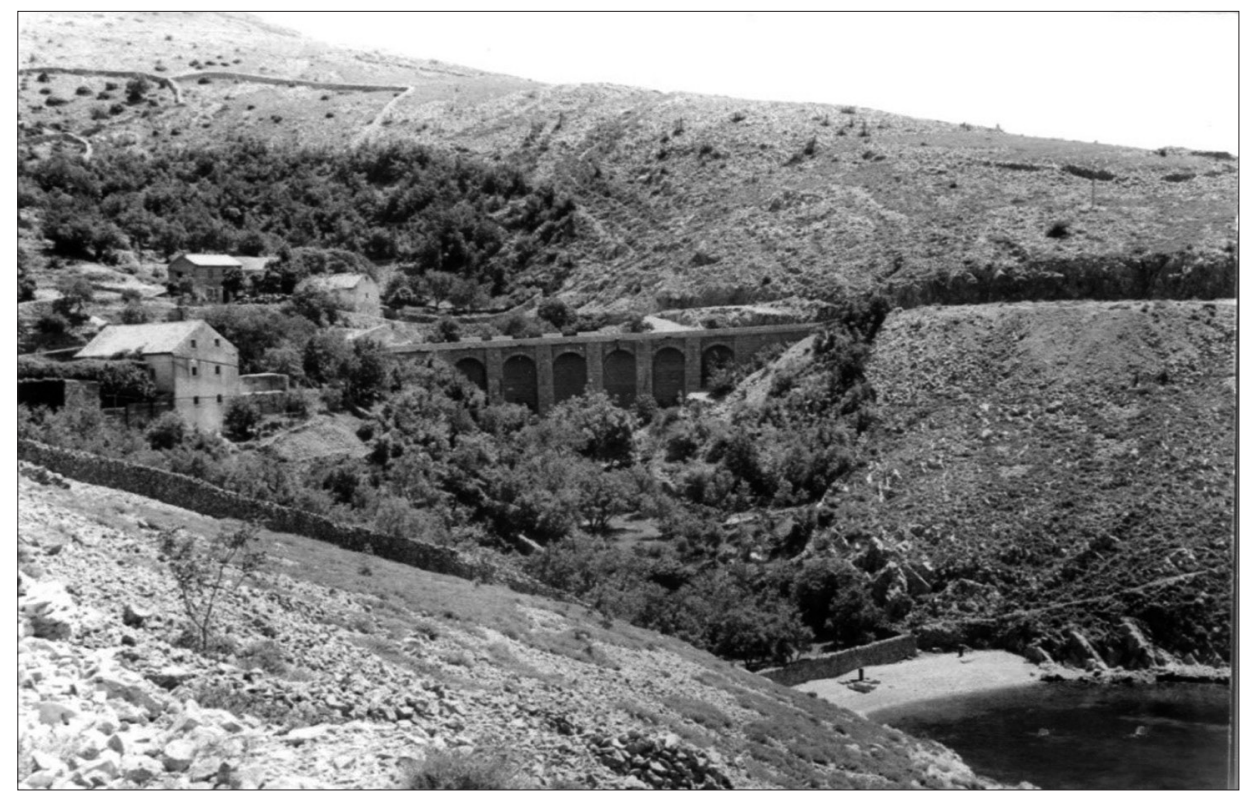

Sl. 35. Ostatci zidova samostana sv. Jelene u Vlaškoj dragi (izvor: Gradski muzej Senj)

Salvatoris) u Senju spominje također samostan sv. Jelene (sanctae Helenae). ${ }^{310}$ Međutim, vjerojatno je i on, kao i samostan Sv. Spasa, polovicom 16. stoljeća bio napušten i porušen zbog turskih nadiranja na Senj u to doba. M. Sladović drži da su prigodom rušenja samostana i crkava izvan senjskih zidina polovicom 16 . stoljeća bili porušeni i pavlinski samostani sv. Jelene i Sv. Spasa. ${ }^{311}$ Vjerojatno to nije učinjeno zbog turske opasnosti za Senj, već se kvalitetno kamenje napuštenog samostana i crkve koristilo za gradnju Nehaja. Da navedemo ovdje još i ovo što nam je o samostanima Sv. Spasa i sv. Jelene zabilježio isti Sladović: "Koliko bijaše otacah u Sv. Spasu i Sv. Jeleni ne čitam, ali gledeći na malenkost nekadašnje zgrade i na povedanje ovdašnjih staracah biaše jih do četiri, pet, koji su pristajućim brodom iz za nevremena ili tamne noći vrlo pripomoćni bili. Strah turski razagna i njih, koje lepa zidanom obalom proviđena luka Spasova pominje." 312

Od staroga samostana sv. Jelene ostale su samo ruševine. Na staroj karti iz 18. stoljeća zapadno od Senja u četvrtoj dragi (selo Pijavica) nalazi se oznaka

\footnotetext{
${ }^{310}$ M. SLADOVIĆ, 1856, 217-218.

${ }^{311}$ M. SLADOVIĆ, 1856, 236-237.

${ }^{312}$ M. SLADOVIĆ, 1856, 224.
} 
"ruševina samostana". Ustvari to su ostaci neke veće građevine (tzv. grčke kuće) izrađene od kamena u tehnici suhozida, a koja je vjerojatno pripadala stanovnicima doturskog doba. ${ }^{313}$ Pravi ostaci pavlinskog samostana sv. Jelene nalaze se u petoj dragi, zapadno od ruševina crkve sv. Jelene, po kojem je i prozvan bunjevački zaselak Sveta Jelena (iz kraja 17. stoljeća), oko $4 \mathrm{~km}$ zapadno od Senja. Na spomenutoj karti, na tom mjestu nalazi se samo crkva sv. Jelene, od koje se i danas vide sačuvani ostaci gotičkih svodova i zidova s neznatnim ostacima fresaka. Da je i taj samostan napušten u isto vrijeme kada i ostali sakralni i drugi objekti izvan zidina (a ne tek u 18. stoljeću po ukidanju samostana za cara Josipa II.), kaže M. Viličići ${ }^{14}$ da svjedoči baš ta zemljopisna karta iz 1765. godine na kojoj je već upisan kao "Ruine Kloster" na sjevernoj strani granice senjskog područja uz uvalu St. Helena, današnju Svetu Jelenu. Tamo se još vide ruševine tog samostana koji se spominje u velikom broju darovnica Frankopana iz 15. stoljeća.

U svojim Putnim uspomenama Kukuljević Sakcinski navodi: "Prvi znamenitiji predmet koj pada u oči, bijahu ruševine pavlinskog samostana sv. Jelene, koj pol ure od Senja udalje po jednom brdašcu leži. Crkvica sv. Jelene je pokraj njekoliko kuća sačuvana, a ne daleko od nje stoji klana sv. Josipa, možebitna tužnu uspomenu Josipa cara, koji je pokraj inih i taj samostan digo. Red pavlinski imao je uobće u Hrvatskoj, a napose u senjsko-modruškoj biskupiji znameniti broj samostana.. Ovi samostani čuvahu mnogu hrvatsku starinu, ponapose glagolske rukopise i listine." ${ }^{1315}$

Područje četvrte i pete drage (Pijavica i Sv. Jelena) tijekom srednjeg vijeka pripadalo je samostanu sv. Jelene i senjskim građanima. Tu, kao i na čitavom području senjskog kotara u dotursko vrijeme, prostirali su se zeleni vinogradi, livade i manji gajevi i voćnjaci uz nešto obradive zemlje kako se to i danas može vidjeti. Na strani daleko od mora, uvijek suncu okrenuti nalaze se bezbrojni zarušeni zidovi lijeha (terasa). Unutar takvih vrtova ponegdje se nalaze tzv. grčki bunar i zidine, podivljala loza, ostaci gospodarskih zgrada i kuća četvrtastog tlocrta, debelih zidova izrađenih u tehnici suhozida. Nekoć, u dotursko vrijeme sva je ta zemlja bila obrađena. Čini se da ta zemlja nije bila tako gola i škrta, a to nam potvrđuju stari Bunjevci koji tu generacijama žive.

Između četvrte i pete drage je mala livada, ravnica uz more, tzv. "Kulina". Iznad ceste sačuvani su ostaci masivnih zgrada i većih zidina čije su ruševine

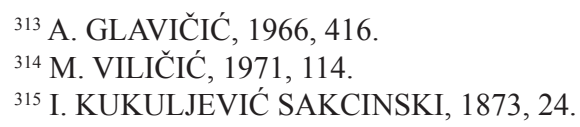


zatekli Bunjevci u 17. stoljeću te ih prozvali "Kulina". Niže ovih zgrada su podzidane terase s debelim slojem zemlje crvenice. Čitav taj prostor bio je kultiviran i u njemu se živjelo, što dokazuju ostaci rimske keramike u zemlji na ledini pod cestom. Sa sjeverne i južne strane četvrte i pete drage (Pijavice i Sv. Jelene), a iznad magistrale nalaze se stari napušteni vrtovi, tzv. "Brdina", gromače s podzidima i lijehama prastarih nastambi u tehnici suhozida bez upotrebe maltera $(40 \times 4 \mathrm{~m})$. To su kuće Hrvata koji su ovdje živjeli prije iseljenja pred Turcima (15. - 16. stoljeće); narod ih zove "grčke kuće ili zidine". Tu se nalaze keramike izrađene na lončarskom kolu (od pečene ilovače), domaća i uvozna roba. Stanovnici "Brdine" (pod Kresom) uglavnom su bili stočari i ratari. Njihove najbolje zemlje nekada su se nalazile, a i danas se nalaze na području Klarićevca, Francikovca i Vrataruše. Pored toga bavili su se vinogradarstvom i ribarenjem.

\section{Crkva i samostan sv. Nikole u Senju}

Na današnjem Pavlinskom trgu - jedinom ovećem prostoru gdje se grad otvara prema moru - nalazio se do druge polovine 19. stoljeća stari samostan $\mathrm{s}$ crkvom sv. Nikole iz 14. stoljeća koji je zbog trošnosti porušen 1874. godine s dijelom gradskog bedema i prastarim vratima sv. Jeronima ("Rumenja vrata" od hrvatskog oblika Rumin-Jeronim). ${ }^{316}$

Prvi spomeni crkve sv. Nikole u Senju vezani su uz dolazak dominikanaca. ${ }^{317}$ Naime, senjski biskup Portiva na molbu dominikanske provincije Dalmacije 24. svibnja 1378. godine daje dominikancima, u dogovoru s kaptolom, crkvu ili kapelu sv. Nikole u Senju. Rečenu molbu preporučila je hrvatsko-ugarska kraljica Elizabeta. Crkva se tada nalazila izvan grada Senja, nasuprot gradskim vratima koja se nazivaju Ruminja vrata. Uz crkvu sv. Nikole nalazila se tada i crkva sv. apostola Filipa i Jakova. ${ }^{318}$ Ruminja vrata ne mogu biti "morska vrata", nego vrata koja su vodila na granice grada prema potoku, preko kojega se nalazila crkva ili kapela sv. Nikole. Ruminja vrata su, dakle, bila na kraju ulice koja se danas zove Ruminja vrata, a vodi od Male place (Frankopanskog trga) prema Pavlinskom trgu.

${ }^{316}$ Ruminja vrata nisu "morska vrata". Ona su izlazila prema potoku (bujici). Potok je tada bio i gradska granica, tako da se crkva sv. Nikole nalazila izvan grada jer je bila preko potoka. Krajem 14. stoljeća ili početkom 15. na tom mjestu grad je prešao preko potoka i tada se i Sv. Nikola našao unutar grada.

${ }^{317} \mathrm{O}$ njihovom boravku u Senju u dijelu o dominikancima.

${ }^{318} \mathrm{CD}$ XV, 366. Krajem 14. stoljeća došlo je do pomicanja gradskih vrata pa se i crkva sv. Nikole tada našla unutar zidina. 
Spomenutu darovnicu biskupa i kaptola potvrdili su također Krčki i senjski knezovi (Frankopani), senjski podžupan, vikar, suci, cijelo vijeće i općina. Darovnicu u ime dominikanaca primio je o. Ivan iz Šibenika koji je u to vrijeme bio generalni vikar provincije Ugarske za Dalmaciju i Albaniju. Uz njega se kod preuzimanja spominju još i ovi redovnici: prior ninskog samostana Toma stariji iz Zadra, Pavao iz Krka, Toma mlađi te Jakov iz Zadra. Spominju se također i svi senjski kanonici. Iz navedenog dokumenta proizlazi da crkvu nisu gradili dominikanci, nego da je ona već postojala i bila vlasništvo kaptola i njima je darovana. Budući da crkvi sv. apostola Filipa i Jakova više ne nalazimo spomena, zacijelo je ona uključena u kasniji samostanski kompleks. Nakon najnovijih iskapanja, može se vidjeti dimenzije crkve koja je 1874. godine porušena, ali svakako da je put prema toj crkvi imao više faza: od početne kapele do respektabilne crkve koja je na koncu po veličini slična crkvi sv. Franje u Senju.

Samostan je uskoro bio sagrađen i nastanjen redovnicima, Prvi put se spominje, prilikom odjeljivanja provincije Dalmacije od provincije Ugarske 1380. godine u buli pape Urbana VI. kojom je ustanovljena dalmatinska dominikanska provincija. Tom bulom provinciji je dodijeljeno 14 samostana ugarske provincije, među njima i senjski. ${ }^{319}$ Taj samostan bio je neko vrijeme središte Senjske ili Hrvatske dominikanske kongregacije, što znači da je imao neki ugled i veličinu. Kao i drugi samostani i dominikanski je dobio neke posjede, ali su oni izvan zidina početkom 16. stoljeća izgubljeni, a tako su izgubljeni i prihodi za uzdržavanje. Kralj Ferdinand I. 1554. godine određuje od dohodaka tridesetnice 24 forinta i samostanu sv. Nikole. ${ }^{320}$ Pomoć nije bila redovita niti je mogla zadovoljiti potrebe samostana i crkve. ${ }^{321}$ Kako je njihovo materijalno stanje bivalo sve teže, obratili su se za pomoć i papi. U Rimu je njihova molba dugo čekala na red jer je Urban VIII. tek 1635. godine odgovorio na njihovu molbu podijelivši oproste oltaru Majke Božje. ${ }^{322}$ No, dominikanci su skoro 20 godina prije napustili samostan i Senj.

Dominikanci su, dakle, u Senju ostali do drugog desetljeća 17. stoljeća. U samostanu su kratko vrijeme boravili augustinci323, a 1634. godine i samostan i crkvu preuzimaju pavlini.

${ }^{319}$ S. KRASIĆ, 1971, 299.

320 "St Nicolaus Closter, darinnen die weisen bruder wohnen 24 gulden" (R. LOPAŠIĆ, SHK, I, 18).

${ }^{321}$ No, za taj prihod morali su ponovno moliti 1604. i 1612.(14). godine.

${ }^{322}$ D. FARLATI, 1769, 139. Farlati dodaje da nije poznato zašto su otišli.

${ }^{323}$ M. MEDVED, 2015-2016, 443-452. 
Premda je ovaj dolazak pavlina u Senj relativno novijeg datuma, nije nam mnogo poznato o njihovoj djelatnosti. ${ }^{324} \mathrm{U}$ darovnici od 10. ožujka godine 1634. godine ${ }^{325}$ biskup Agatić kao razlog dovođenja pavlina navodi nebrigu dotadašnjih redovnika, tj. dominikanaca i augustinaca, za uzdržavanje crkve i samostana te vjerski nemar istih redovnika. Izgleda da su dominikanci napustili samostan prije dolaska Agatića (1617.), a kad je on preuzeo biskupiju pokušao je dovesti onamo svoje augustince. ${ }^{326}$ Oni su došli u Senj, ali su samostan napustili i prije nego su učinili ozbiljne korake da ga obnove. Rezultat toga je bio da je samostan kroz to vrijeme sve više stradavao. Biskup se okrenuo pavlinima u kojima vidi dobre pastoralne radnike, kojih je inače bilo u gradu premalo. Izričito navodi da ga za to nisu pavlini molili (vjerojatno da ne poremeti odnose između dviju redovničkih zajednica) niti ga je itko izvana na to nagovorio. Učinio je to po svom osobnom nahođenju ("ex mera nostra liberalitate") i to u ime vlasnika i nasljednika. Te neuobičajene riječi sigurno imaju neki posebni razlog, a premalo imamo elementa za korisna nagađanja oko tih razloga. ${ }^{327}$ Prema jednoj bilješci M. Sladovića čini se da se ovdje radi o pavlinima koji su došli izvana, tj. da se ne radi o pavlinima koji su već tada bili u Senju (u pavlinskom samostanu u Sv. Jeleni ili Spasovcu). On naime kaže da se u ovom slučaju radi o redovnicima većinom strancima. Evo što je o njihovom redu zabilježio M. Sladović: "U samostanu sv. Nikole bijahu poprije dominikanci (oci reda sv. Dominika), a još prije augustinovci. Pavline potvrdi cesar Ferdinand III (5.XII.1646.) pa Leopoldo (10.LX.1660) i oni učahu

${ }^{324}$ U Pavlinskom fondu Arhiva Hrvatske imamo za većinu pavlinskih samostana posebni popis i fascikl za pojedini samostan. Sv. Nikola u Senju, međutim, nema tako nečega jer se on, poput drugih samostana, nije mogao pohvaliti srednjovjekovnim darovnicama. Spis o tom samostanu nalazimo u fasciklu: Razni samostani. Tu je također, darovnica biskupa Agatića iz 1634. godine (br. 6) i Inventar samostana i crkve iste godine, što ga je sastavio pavlin Nikola Vlahović (br. 7). U Biskupskom arhivu u Senju (BAS) sačuvano je malo spisa oko godine kada je samostan ukinut (fasc. II, br. 14, fasc. VI, br. 23, fasc. IX, br. 30). Većina građe nalazi se u Hrvatskom državnom arhivu u fondu Generalcommando jer se samostan nalazio unutar Vojne krajine. Najopširniji i najcjelovitiji prikaz tog samostana dao je u spomenutom rukopisu Kamilo Dočkal.

${ }^{325}$ M. SLADOVIĆ, 1856, 232-233.

326 Vidi o tom pokušaju članak Marka Medveda, Augustinci pustinjaci u Senju, Senjski zbornik, 42-43, Senj, 2015-2016, 443-452.

${ }^{327}$ Kamilo Dočkal, a i Pavao Tijan, smatraju na temelju ovih riječi da je samostan bio biskupijsko vlasništvo, biskupija ga je jedno vrijeme "iznajmila" dominikancima, a 1634. godine pavlinima. Ne znamo koliko je to svoje pravo biskup osnivao na ispravi iz 1378. godine kada je njegov prethodnik Portiva darovao dominikancima kapelu sv. Nikole u Senju (usp. CD XIII, 366). Pri prosudbi svakako treba imati u vidu da su tada u Senju civilna i vojna uprava i da je između njih bila trajna napetost pa je zbog toga treća (crkvena) vlast katkada nastupala kao kompromisno rješenje. 
šest latinskih školah, a jedan mimo to katehezu u stolnoj crkvi i držahu nemačke propoviedi za službujuću nemačku gospodu. Začudo je da je malo našieh imenah među onim Pavlini naći, većinom Nemci i gdje koji Slovenac iz dežele." 328

Samostan koji je biskup Agatić htio spasiti od propasti jer je bio u lošem stanju $^{329} \mathrm{u}$ ime pavlina preuzeo je generalni prokurator i provincijal o. Ivan Bakić (Pakitio) koji je postao prior. Uz njega na početku nalazimo još samo Nikolu Vlahovića. ${ }^{330}$

Biskup ne daje pavlinima posebni zadatak. Njemu su oni poznati po čestitosti i učenosti (doctrina), ali ne bismo samo iz toga smjeli zaključiti da ih je doveo s ciljem da poučavaju mladež, osobito kandidate za svećenike, kako se obično komentira njihov dolazak 1634. godine.

Kako je već spomenuto, biskup Agatić kaže 1634. godine da je samostan veoma ruševan (extremam minari ruinam). ${ }^{331} \mathrm{Da}$ je to bilo tako, vidi se i iz inventara koji je iste godine sastavljen. ${ }^{332} U$ inventaru nemamo, doduše, opis crkve i samostana kao građevine, ali se po siromašnom inventaru može zaključiti na opću zapuštenost tih ustanova.

U sakristiji se nalazi jedan srebrni i jedan slomljeni kalež od nenaznačenog materijala, zatim jedan od bakra bez vrijednosti. Slijedi srebrna kadionica i lađica, mali srebrni križ i komadi drugoga i slomljeni kip svetoga Nikole. I to je sve što je u sakristiji vrijedno spomenuti. Napominjemo da je taj slomljeni kip sv. Nikole vjerojatno još iz one prve crkvice. Dominikanci izgleda nisu više postavljali sv. Nikolu na oltar, bar ne na onaj glavni. Pavlini su poslije izgradili raskošan glavni oltar, ali on je bio posvećen Presvetom Trojstvu. Nijedan od ta dva reda nije posebno štovao sv. Nikolu. Inače bi crkva sv. Nikole postala crkva senjskih mornara, a ne ona na Artu. Na glavnom oltaru dva su drvena svijećnjaka. Na slikama su tri polukrune. Ne kaže se o kakvim se slikama radi, ali vjerojatno je već tada na oltaru Presveto Trojstvo.

Drugi oltar posvećen je sv. Vinku. Na četvrtom i petom oltaru jednako su loši svijećnjaci. Također ne znamo kome su oltari posvećeni. Na petom oltaru,

${ }^{328}$ M. SLADOVIĆ, 1856, 233.

329 "Ipsum claustrum extremam minari ruinam" (M. SLADOVIĆ, 1856, 232).

${ }^{330}$ Hrvatski državni arhiv, Pavlinski samostani, Razni samostani br. 7.

${ }^{331}$ U Agatićevoj darovnici iz godine 1634. spominje se da su u samostanu prije bili dominikanci i augustinci. Nema nigdje drugdje tragova boravka augustinaca u tom samostanu, čak ni u Senju. Moguće da je, prije nego je pozvao pavline, Agatić razgovarao s riječkim augustincima, među kojima je i sam prije nego je postao biskupom boravio i kojima je pripadao i da je neki dogovor već bio postignut, ali nije bio do kraja realiziran.

${ }^{332}$ Hrvatski državni arhiv, Pavlinski samostani, Razni samostani, br. 7. 
posvećenom Gospinoj krunici, na glavi Majke Božje nalazi se pet (!) srebrnih kruna. Uz to se u crkvi nalaze još dvije bezvrijedne zastave.

U samostanu se nalaze stol i ormar bez vrijednosti, peć, četiri limena tanjura i dvije zdjele, bez kreveta. Sastavljač inventara, pavlin Nikola Vlahović, ovako završava: "Ovaj siromašni, bijedni i zapušteni samostan povjeren je našemu redu." Zatim slijede neki dodaci iz kojih doznajemo za prve poduzete korake. Prvi prior Ivan Bakić kupio je jednu kuću za kuhinju i blagovaonicu za 100 dukata koje je dao Martin Gregorovic za jednu samostansku kuću u Senju. ${ }^{333}$ Kao prokurator samostana spominje se Vinko Čolić. Godine 1640. uz Bakića se spominje i Nikola Vlahović.

Prema grafičkom dokumentarnom materijalu teško je zaključiti o izgledu crkve. Da su je podigli dominikanci, mogli bismo vjerovati da je građena u duhu rane gotike, na način na koji su franjevci i dominikanci izgrađivali svoje crkve. No, kako svi dokumenti govore o tome da je ona dominikancima darovana, znači da je izgrađena prije, od drugih graditelja. Ne znamo je li to bilo u duhu romanike ili gotike. Darovana crkva svakako nije mogla zadovoljiti potrebe samostanske crkve pa je proširivana i nadograđivana. Danas se nakon iskapanja ne mogu pročitati konture te $\operatorname{crkv}(\mathrm{ic}) \mathrm{e}$.

Crkva i samostan bili su poslije i uređivani i prošireni, kako zbog potrebe samostanskog osoblja, tako i zbog sve značajnije uloge pavlina u Senju, o čemu je već gore bilo govora. ${ }^{334}$ Najveće proširenje bilo je onda kada je uz samostan dograđena gimnazijska zgrada koju je sâm car na vlastiti trošak sagradio. To je bilo oko 1725. godine jer te godine je gimnazija počela raditi. Od 1746. do 1749. građen je novi glavni oltar. Još je sagrađen i oltar Žalosne Gospe. Nakon zatvaranja samostana i crkve ovaj posljednji prenesen je u senjsku katedralu gdje se i danas nalazi. Uza nj je bila vezana istoimena bratovština, koja je također prenijela svoje sjedište uz katedralnu crkvu. Glavni oltar rastavljen je 1707. godine, a 1790. godine složen u župnoj crkvi u Puntu gdje se i danas nalazi. ${ }^{335}$

Samostan s crkvom sv. Nikole prikazan je u planovima i vedutama grada Senja 17. i 18. stoljeća. U Stierovoj veduti iz 1660 . godine iza zidina na obali

${ }^{333}$ Iz ovoga se vidi da su pavlini imali neprekinutu vezu sa Senjom i nakon što su nestali samostani Sv. Spasa i sv. Jelene.

${ }^{334}$ M. Sladović piše $(1856,233)$ da pavlini koji su došli u Senj 1634. godine nisu bili iz naših strana, nego da su stranci, što da se vidi iz njihovih njemačkih prezimena. Međutim, očito je da su prvi imali naša prezimena. Poslije su zbog potrebe njemačkog propovjednika u Senju te njemačkih i latinskih škola došli i neki stranci. Jednako je očito da samostan sv. Nikole u Senju nije bio na liniji glagoljaške tradicije koju su držali prijašnji samostani na našem području.

${ }^{335}$ K. DOČKAL, Samostan sv. Nikole, 24. 


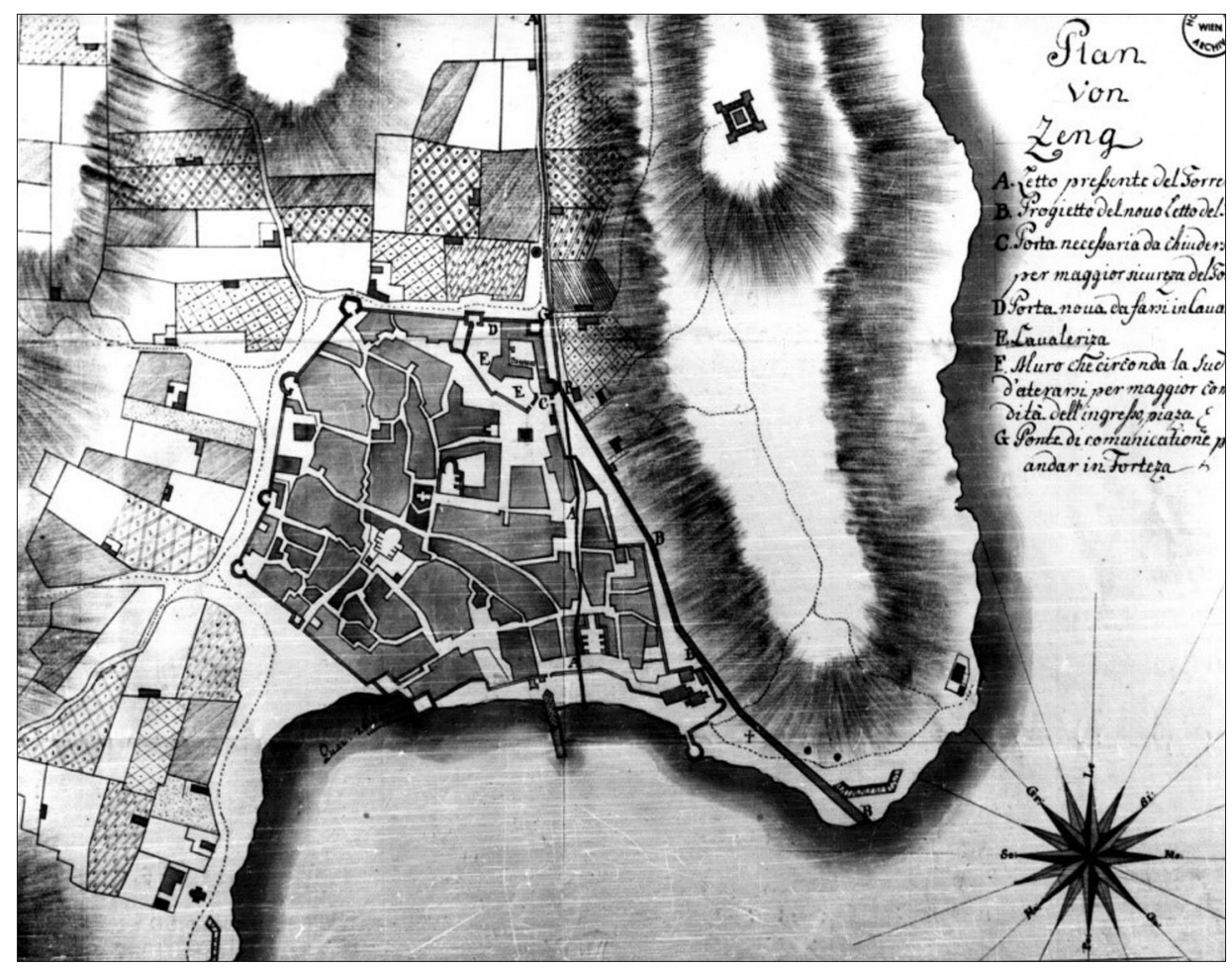

Sl. 36. Crkva sv. Nikole i sv. Franje sa samostanom na Planu Senja iz 1763. (izvor: Beč, Arhiv dvorske komore, O-162)

može se nazrijeti objekt koji bi mogao predstavljati crkvu sv. Nikole. Prikazana je bez tornja s preslicom nad zabatom. Slično je tako narisana i u Valvasorovoj knjizi 1689. godine gdje se u opisu Senja spominje i crkva sa samostanom. Međutim, veduta iz godine 1749. prikazuje iza zidova objekt crkve s tornjem, s pokrovom poput onoga na tornju franjevačke crkve - dok je toranj katedrale i dalje bez pokrova i sliči obrambenoj kuli. Nad tornjem crkve sv. Nikole piše: Pauliner.

Na planu iz 1763. godine jasno je prikazan njezin tlocrt kao trobrodne bazilike iako su tlocrti drugih sakralnih objekata na tom planu gotovo samo simbolički urisani. Nije, međutim, naznačeno unutarnje dvorište samostana, nego je vidljiv samo cjelokupni sklop crkve i samostana koji je bio situiran na dovoljnoj udaljenosti iza gradskih zidina. Na tom planu urisana je bujica koja je

${ }^{336}$ J. W. de VALVASOR, 1689, 179. 
tekla Senjom i koja je mnogo puta nanijela štete gradu. Ovdje se vidi kako njezin tok prolazi pokraj crkve i samostanskim sklopom te je vjerojatno mnogo puta oštetio njezine objekte. Plan iz 1779. godine već pokazuje projekt širenja grada izvan zidina. Neki manji objekti prizidani su uz gradske zidine prema moru. Sklop crkve i samostana udaljen od zidina ima naznačen presvođen prolaz do zidina. I plan grada iz 1785. godine, nakon napuštanja samostana po pavlinima, prikazuje kompleks crkve i samostana iza zidina grada. Naznačen je slovom 1-napušteni pavlinski samostan i crkva (l-Das aufgeschobene Pauliner Kloster und Kirche). U zidinama prema moru pred samostanskim objektom urisana su mala vrata, označena s e-pavlinska vratašca (e-Das Pauliner Thurl). I ovdje je urisana bujica, što je po njezinom toku očito da je podrivala objekt ( $A$ bis $B$ der Lauf des Schadlichen Wildbach Torrente gonannt). Plan iz vremena nešto prije 1800. godine prikazuje unutar tamnije obojene površinske plohe samostan. Isto piše i na planu iz 1857. godine (exPauliner Kloster). Još se vide linije zidine uz more. Na situacijskom planu iz 1839. godine vidi se da nema više zidina prema moru, ne vide im se više ni tragovi pred objektom crkve i samostana. Na samostanskom kompleksu piše: "bivši pavlinski samostan" (exPauliner Kloster). Isto piše i na planu iz 1857. godine na kome je već urisana i regulirana luka, $\mathrm{s}$ druge strane, pred magazinima soli. Iz vremena između ta dva plana je litografija Knara koja prikazuje Senj u to doba. Zidina prema moru više nema i u prvi plan dolazi samostan - tada škola - s crkvom sv. Nikole. Tek iz nešto kasnijeg vremena, iz 1869. ili 1873. godine, potječe najstarija sačuvana fotografija Senja $\left(\right.$ Standlova $\left.{ }^{337}\right)$, koja prikazuje frontu Senja prema moru. Tu se jasno vidi crkva sv. Nikole s tornjem i trokatni samostanski objekt. To je bila velika građevina s četverokutnim tornjem i okruglom kupolom kakvi su bili uobičajeni u Primorju.

Godine 1770. pavlini su trebali odgovoriti na neki upitnik s obzirom na njihov boravak u pojedinim samostanima, na njihovu djelatnost i prihode. $\mathrm{U}$ senjskom samostanu bio je tada prior Florijan Grosshänden. Donosimo u nešto skraćenoj verziji priorove odgovore. Tekst je potpisao uz priora i provincijal za Istru i Vinodol Stanislav Kattanar. Evo što piše prior: "Osnivač ovog samostana bio je presvijetli i prečasni gospodin senjski i modruški biskup Ivan Krstitelj Agatić koji je godine 1634. desetog ožujka uveo oce u grad Senj, davši im crkvu posvećenu sv. Nikoli, biskupu i ispovjedniku, sa samostanom uz crkvu, zauvijek i neopozivo, nakon što su je napustili dominikanci i augustinci. Nije poznato koliko je bilo redovnika u času dolaska. Da ih je bilo malo, vidi se iz pisma prečasnog i presvijetlog biskupa Agatića kao i iz skučenosti prostora koji im

${ }^{337}$ HKS, slika 24. 
je dodijeljen. $S$ vremenom je rastao broj, sigurno i do 24 osobe, a samostan ih je mogao lako hraniti $i$ uzdržavati jer se hrana i odjeća mogla za nisku cijenu nabaviti, a samostan je potporom careva i darovima građana mogao biti proširen. Sada se broj penje jedva do dvanaest redovnika i tri sluge, ali ni toliki broj ovaj siromašni samostan ne može dolično uzdržavati. Grad je, naime, pao u bijedu tako da se ne dobiva ni milostinja ni darovi, niti ljudi mogu dati nešto za mise jer su cijene potrepština za život previsoke. Godine 1661. uzvišeni car Leopold I. udijelio je ocima povlasticu da sagrade pekaru za svoje potrebe i za potrebe grada. Od toga dobivaju godišnje 45 forinti." 1338

Godine 1725. slavni carKarlo VI. osnovaoješest razreda škole (humaniores) i povjerio pavlinima da poučavaju senjsku mladež u kreposti i pismenosti, a za to su godišnje dobivali od prihoda senjske carinarnice (ex Telonio) 400 forinti. Preblagom carskom i kraljevskom odlukom iz kase vrhovnog predstavništva u Ljubljani dodjeljivano je poslije uz to još 54 forinta. Također iz kase glavnog poreznog ureda u Senju godišnje 39,16 forinti. Za služenje misa jedva dobiva 64,48 forinti. Izvan grada ima vrt kod izvora za koji treba godišnje odslužiti 12 misa, a samostan dobiva 9 forinti. Svega ukupno 612,4 forinti. ${ }^{339}$

Pavlini su, dakle, ostali u Senju do 1786. godine. Car Josip II. ukida taj samostan spomenute godine i od onda je u njemu škola do 1874. godine kada se samostan i crkva sv. Nikole ruše zbog dotrajalosti. Tom zgodom oltar Majke Božje Žalosne prenesen je u senjsku katedralu, dok je glavni oltar sv. Nikole prodan župnoj crkvi sv. Trojice u Puntu na otoku Krku gdje se i danas nalazi (lijep barokni oltar s rezbarijama i skulpturama u drvu i sa slikom Kristova krštenja od Maggiota). Zbog svoje umjetničke vrijednosti ovaj je oltar u popisu spomenika kulture. Kako na njemu piše, rađen je od 1746. do 1749. godine (Dieser Altar ist angefangen gruenden im Jahre 1746. und ausgefertig 1749.). Čini se da je rađen u Tirolu kako piše u Inventaru župne crkve u Puntu. O njegovom pak podrijetlu

${ }^{338}$ Biskup Glavinić piše 1695. godine da je u samostanu pet pavlina. Bedeković kaže da je 1706. samostan proširen te da je prikladan za osam redovnika, dok je prije mogao primiti samo pet. Sama samostanska zgrada nije zacijelo tako malena, nego nije bila sva uređena za stanovanje. Najveće proširenje i preuređenje bilo je oko 1725. godine kad su pavlini preuzeli brigu za školu i od kada su imali stalnu državnu dotaciju. U sljedećem desetljeću broj je mogao biti najveći. Prema izvještaju biskupa Čolića, godine 1748. bilo ih je 14. Godine 1770. nalazimo u samostanu 12 redovnika i 3 sluge. Prigodom ukidanja samostana bilo je po prilici isto brojno stanje. Iz različitih spisa došao sam do ovih imena: Alfonz Dolinić, Leonard Herko, Viktor Orlić, Nepomuk Skornjak i Starika. U Senju su ostali samo Orlić i Herko radi škole. Ostali su otišli na župe ili u mirovinu.

${ }^{339} \mathrm{BAS}$, fasc. II, br. 14. Zbroj inače iznosi 611,64 forinta. Tu treba dodati i legate u vrijednosti od 2090 forinti. 
i prijenosu u Punat govori nam drugi natpis na samom oltaru: "Bi razvršen ov oltar u crikvi sv. Mikule monaci sv. Pavla reda leta 1787. Bi postavan na Punat u crikav sv. Trojice 5. misecza marča na 17 leta 1790. Mene expaulina imenom Seraphin Trulich, laicus". ${ }^{340}$

Dokumenti o pavlinskim samostanima sačuvali su nam se relativno dobro najviše zbog toga što je prigodom dokidanja reda trebalo utvrditi što je bilo u posjedu pojedinih samostana, odnosno čime se dokazuje da je što samostansko vlasništvo. Sačinjeni su tada inventari pavlinskih crkava i samostana, ali još nisam naišao na inventar samostana i crkve sv. Nikole u Senju, premda se u više navrata o njemu govori. Od prodanog samostanskog pokućstva i srebra već je 1787. godine dobiveno 1548 forinti. Prodaja se nastavila, ali je dosta toga bilo podijeljeno. Od pokretnina dosta je dano članovima samostana pri odlasku iz župe. Misno ruho dano je siromašnijim crkvama na području karlovačke Vojne krajine. Dosta toga prešlo je u vlasništvo drugih crkava u Senju. Što je još danas od inventara sačuvano, moći ćemo utvrditi tek onda kada budemo imali popis predmeta koji su se našli u vrijeme dokidanja samostana i sekulariziranja crkve. Tijan misli da je samostan po veličini bio sličan onome franjevačkom. ${ }^{341} \mathrm{I}$ crkva je u 18. stoljeću morala biti velika poput one franjevačke. To zaključujemo na temelju sačuvanih oltara koji su dospjeli u Punat i senjsku katedralu. Najveća proširenja i dogradnje bile su u prvoj polovini 18. stoljeća. Ipak će se pri svemu tome raditi po svoj prilici o obnavljanju starih zidova i nekoj dogradnji, a ne o gradnji iz temelja. Kako inače shvatiti da se 1787. o crkvi kaže da je ruševna. Iste je godine već bio iznesen prijedlog da se i crkva i samostan poruše kako bi se oslobodio prostor za brodogradilište s odgovarajućim spremištem. ${ }^{342} \mathrm{Na}$ mjestu srušene crkve i samostana kasnije je bila tržnica i ribarnica.

Prije nego je crkva bila 1874. godine porušena, posjetio ju je Ivan Kukuljević Sakcinski i očitao s nadgrobnih ploča šest natpisa koji su poslije objavljeni. Tako su nam se bar u knjizi sačuvali. ${ }^{343}$ Evo tih natpisa:

1. Natpis nad grobom Ivana Foljanića iz 1514. godine O VIATOR! GESTA, DECOR. OPES. AETASQUE FLORIDA. QUID PRODEST HIC MAGNALI (?) TAM (?) IACEO IOANNES FOLLIANICH. Rq COMES EN ENMANIS (?) VIRQq PIEQq PIET. EXPECTANS. MDXIII. KAL. XIX. FEBR.

${ }^{340}$ Historijat i inventar župne crkve u Puntu, 1956, 3.

${ }^{341}$ Ondje, str. 20-27, 48. P. TIJAN, 1937, 67-71.

${ }^{342}$ Hrvatski državni arhiv, Generalcommando Karlovac, kut. 14, br. 17.

${ }^{343}$ I. KUKULJEVIĆ SAKCINSKI, 1891, 240, br. 801 i 802; 241, br. 803 i 804; 247, br. 828; 249 , br. 835 . 
2. Natpis nad grobom obitelji Gvainix iz 1514. godine MDXIV. B . G. M. S. HACQ . LOCVPLEX BONETAS IN VRBE NVDVS

ET IN NVDO NVNC REQVIESCIT HVMO. HAEC AVE NATI PIA SVNT MONVMENTA GVAINI QVAE CVM TOTA POSTERITATE MANENT. ET QVOS VNA DOMVS GENVIT. NON DIVIDAT VRNA. VT SIMVL EXVRGANT VOCE IVBENTE DEO.

3. Natpis na grobu senjskog građanina Jakoba Marina Dubrovčanina de Crivaldis iz 1516. godine

BREVE AEVVM TEMPVS INCERTVM. IACOBVM MARINVM DE CRIVALDIS RAGVSEUM CIVEM SEGNIENSEM. CATHARINAMQVE CRVAOGNE EIVS VXOREM SIBI SVISQVE HANC DOMVM STATVERVNT CONDERE. MDXVI

4. Natpis nad grobom senjskog župnika arhiprezbitera i vikara Ilije Anijevića, što ga podigoše izvršitelji njegove oporuke modruški biskup Šimun Kožičić Benja i dominikanac o. Albert Bilšić, iz 1517. godine ELIAE ANIEVICH PLEBANO GORITIENSI ARCHIPRESBYTERO ET VICARIO SEGNIENSI SIMON EPICOPUS MODRUSSIENSIS ET FRATER ALBERTUS BILSICH ORDINIS PRAEDICATORUM IADERTINI. TESTAMENTI EIUS EXECUTORES POSUERUNT. ANNO MDXVII.

5. Natpis na grobu Radoja Vlatkovića iz 1587. godine

STRENVI RADOII WLATKOVICH SAC. CAES. MAIEST. ET SERENISS. ARC. AVSTR. MILES SEGNIENSIS HEREDVMQVE SVORVM. VIVVS POSVIT. DIE VII. APRILIS MDLXXXVII.

6. Natpis na grobu Antuna Bonifačića

OVO IE GROB ANTVNA BONI-

FACIA. I NIEGOVA OSTANKA.

Još godine 1936., prigodom uređenja tadanjeg Frankopanskog trga (danas Pavlinskog trga) nailazilo se na urušene grobnice i ljudske kosti. To se ponovilo godine 1958. prigodom postavljanja spomenika "Na vječnoj straži", na dubini od 0,40 - 0,70 m, među zidovima bivše crkve i gradskih bedema naišlo se na dvije oštećene grobnice, a kod hotela "Nehaj" na dijelove samostanskog zida, grobnice i ljudske kosti. 

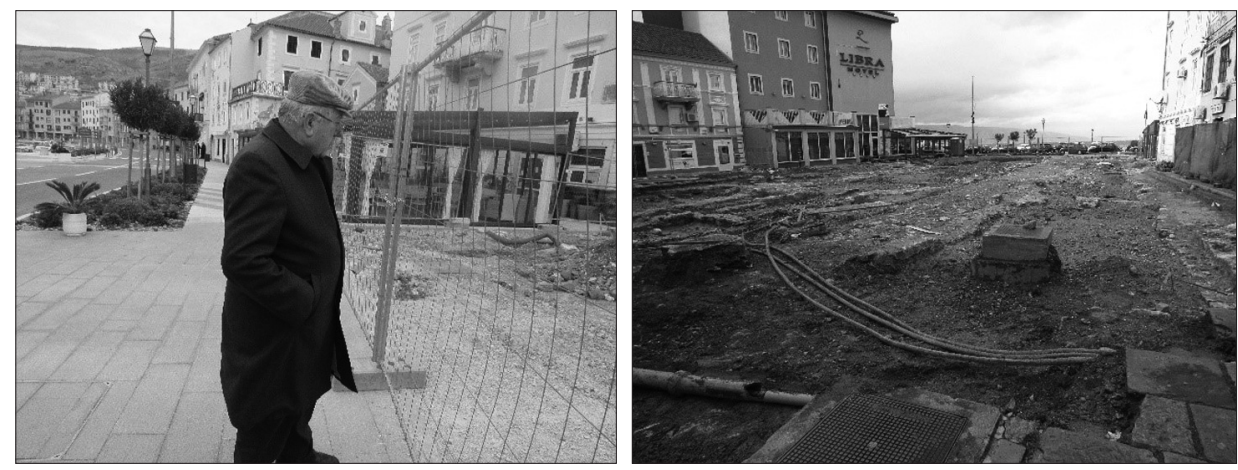

S1. 37. a) i b) M. Bogović u obilasku Pavlinskog trga tijekom radova na uređenju, 18. siječnja 2020. (foto: B. Ljubović)

\section{e) Augustinci}

Augustinci su u Senjskoj biskupiji svoj samostan imali u Brinju. Znamenitiji augustinski samostan bio je onaj u Rijeci. Poznat nam je jedan augustinac iz Senja u tom samostanu - Mansuet Favilla. Kada je 1617. godine umro senjski biskup Vincenc Martena, Sveta Stolica je željela da ga naslijedi ugledni augustinac iz riječkog samostana Ivan Krstitelj Agatić, Riječanin. Među onima koji su bili pitani o stanju Senjske biskupije i o prikladnosti Agatića za senjsku biskupsku stolicu bio je i spomenuti augustinac iz Senja. Kad je Agatić preuzeo biskupiju, našao je u Senju napušteni i ruševni dominikanski samostan sv. Nikole. Dvojac Agatić - Favilla svakako je odigrao glavnu ulogu da se u taj samostan dovedu augustinci. Dosadašnji autori nagađali su da bi u Senju postojao augustinski samostan, ali konkretno otkada i dokada nije nitko potvrdio. Neki su čak mislili da su augustinci bili prije dominikanaca. Sigurno postojanje i vremenski određeno opisao je nedavno Marko Medved. Medved razložno njihov dolazak stavlja oko 1622. godine. ${ }^{344}$ Njihov dolazak svakako nije mogao biti prije nego je Agatić preuzeo upravu biskupije. Njegov prethodnik Martena 1615. godine u izvješću "Ad limina" spominje dominikanski samostan u Senju s dva redovnika ${ }^{345}$, što znači da je odlazak dominikanaca bio oko godine dolaska Agatića na senjsku biskupsku stolicu. Svakako nema razloga dolazak

${ }^{344}$ M. MEDVED, 2015-2016, 443-452.

345 "Sunt enim fratrum monasteria duo: primum Sancti dominici, bini solum fratres tenunt, qui stipendio vivunt florenorum quatuor, quod illis solvit Princeps, et locatibus et eleemosynis; in secundo minorum fratrum Sancti Francisci item sunt duo" (M. BOGOVIĆ, 2003, 126-127). Medved je to previdio. 
augustinaca u Senj stavljati u vrijeme prije Agatićeva biskupskog imenovanja. Ako je papinsko imenovanje bilo 7. srpnja 1617. godine, dolazak augustinaca mogao je biti najranije 1618. godine. Prvi izričiti spomen samostana u Senju je 6. svibnja 1623. godine na augustinskom kapitulu u Koruškom Velikovcu. Tu je bio kao treći definitor i prior senjskog samostana Mansuet Favilla. Favilla je bio, dakle, prior samostana, ali i jedini redovnik koji u njemu živi. No, pitanje je li i on živio baš u tom starom napuštenom samostanu kad je imao obiteljsku kuću u Senju.

Nakon Faville, od priora senjskog augustinskog samostana spominju se 1624. godine Kristofor Kučić, 1626. godine prior je Nikola Šitar (Schittar). On je 1628. godine dobio dva klerika: Petra Kučića i Bonaventuru iz Hvara. Prior senjskog samostana spominje se i 1629 . godine, ali ne spominje mu se ime. $\mathrm{Za}$ razdoblje od te godine do 1633 . Medved nije imao na raspolaganju spise augustinske provincije pa se ne može ništa pouzdano reći. Zna se da se senjski samostan već 1633. godine ne spominje među provincijskim samostanima, što znači da je u međuvremenu dokinut. ${ }^{346}$ Najsigurniji dokaz da se to i dogodilo jest činjenica da je biskup Agatić 1634. godine samostan predao pavlinima.

Nesigurnost u vezi s uzdržavanjem samostana osjeća se još na spomenutom kapitulu iz 1623. godine. Tada je pročitana predstavka riječkog samostana u kojoj se predlaže da se uzdržavanje samostana veže uz posjede u Baški na otoku Krku jer su navodno ondje bili posjedi nekadanjeg brinjskog augustinskog samostana. Ta mogućnost bila je veoma tanka. Istina, ondje su mnogi samostani s kopna imali svoja imanja, ali nije poznato da to vrijedi i za brinjske augustince. Jedina veza može biti s Brinjem što je brinjski augustinski samostan knez Ivan Frankopan predao pavlinima. Nastao je spor, ali svakako krajem 15. stoljeća brinjski samostan pripada pavlinima. Svi su pavlinski samostani na području Senjske biskupije u Primorju i zaleđu imali svoje posjede na Krku jer je to u ono vrijeme bila najveća sigurnost. Pavlinski samostan Sv. Spasa imao je u Bašćanskoj Dragi hospicij sv. Kuzme i Damjana koji je poslije prerastao u samostan. Samostan Sv. Spasa je u prvim desetljećima 16. stoljeća napušten i porušen, ali povezanost redovnika Sv. Kuzme i Damjana sa Senjom gdje su pavlini imali svoje kuće, ostala je trajna. Zato su mnogo veću šansu da dobiju materijalnu potporu iz Baške imali pavlini. To se vidi nakon što su pavlini preuzeli samostan sv. Nikole u Senju jer postavljali su se i kao baštinici samostana Sv. Spasa koji je osnovao najprije hospicij, a onda i samostan sv. Kuzme i Damjana u Bašćanskoj Dragi. Sve u svemu, inicijativa nije zaživjela. Na kapitulu 1633. godine nije izabran prior niti

${ }^{346}$ M. MEDVED, 2015-2016, 447 i 450. 
se poslije u aktima augustinske provincije spominje augustinski samostan pa se može smatrati da već te godine augustinci nisu više prisutni u Senju. Biskup Agatić bio je nezadovoljan neradom i nezainteresiranošću svoje donedavne redovničke braće i 10. ožujka 1634. godine podjeljuje samostan pavlinima.

Za bolje razumijevanje svih tih događaja dobro se prisjetiti da se sve to događa u vrijeme najžešćih uskočkih ratova i njihove pacifikacije protjerivanjem iz Senja. Biskupska kurija bila je također trošna i ruševna pa je Agatić boravio u Bakru ili u obiteljskoj kući u Rijeci.

Možemo zaključiti da je senjski i modruški biskup Ivan Krstitelj Agatić (1617. - 1640.) pozvao augustince da preuzmu napušteni dominikanski samostan u Senju. Marko Medved je uvjerljivo dokazao da su oni oko 10 godina (1622./1623. - 1632.) taj samostan vodili kao svoj, postavljali priora, ali da nisu uložili toliko koliko je trebalo da se samostan održi. Već 1633. godine ne nalazi se Sv. Nikola na popisu njihovih samostana.

\section{Ženske redovničke zajednice}

\section{a) Milosrdnice}

Milosrdnice su najbrojnija ženska redovnička zajednica u Crkvi. Osnovao ih je sv. Vinko Paulski koji je redovnicama otvorio vrata njihovih klauzura i poslao ih u svijet k najpotrebitijima. U Zagreb su došle 1845. godine, u Rijeku 1858., a u Senj 1896. godine. ${ }^{347}$

Najprije su došle 1896. godine u konvikt "Ožegovićianum" i ostale do njegovog zatvaranja 1945. godine. Dvije godine poslije otvorenja nove zgrade "Ožegovićianuma, dakle 1898., dolaze u Bogoslovsko sjemenište i ostaju do njegovog zatvaranja 1919. godine. Djelovale su u gradskoj bolnici i ubožnici (Domu starih) od 1906. do 1932. godine i u banovinskoj bolnici od 1938. do 1944. godine. Ta bolnica je nasljednica prethodne senjske bolnice koja je bila trošna, pa je 1932. godine srušena i napravljena na istom prostoru nova.

Biskup Antun Maurović dobio je od grada bivšu vojarnu i preuredio ju je za odgojni zavod. Zgrada zavoda koju je kupio 1857. godine biskup Mirko Ožegović bila je trošna i malena za zadaću koju je zavodu dao utemeljitelj, biskup Ožegović. Maurović je uredio bivšu vojarnu ili kaštel koji je od tada nosio naziv "Ožegovićianum". Kako je gore spomenuto, sestre milosrdnice došle su dvije godine nakon otvorenja novog Zavoda. Ovdje je njihova uloga

${ }^{347}$ B. VRAČIĆ - A. KOVAČIĆ, 1998, 128-130. 


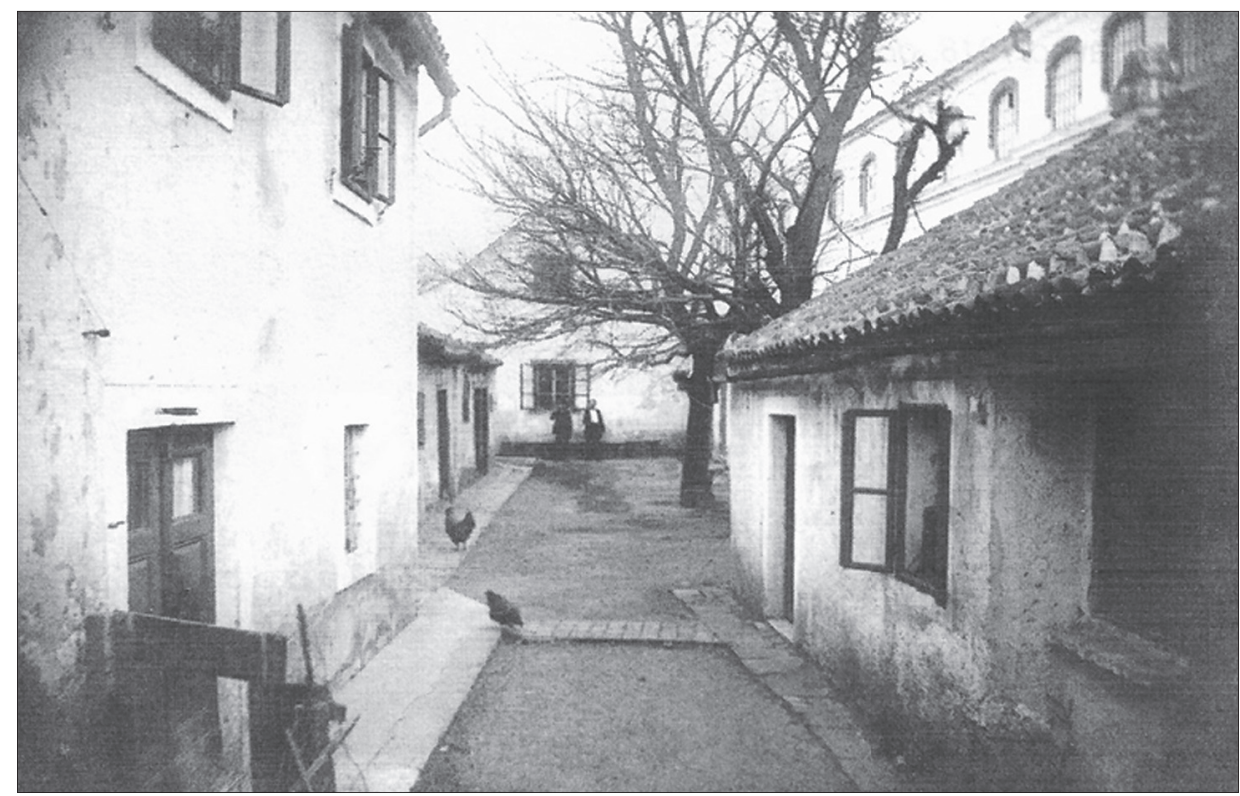

Sl. 38. Bolnica i ubožnica u Senju (izvor: B. VRAČIĆ - A. KOVAČIĆ, 1998.)

bila vođenje domaćinstva, ali su sudjelovale i u odgojnom procesu pitomaca. Redovito je bilo u Zavodu šest sestara. Zbog ratnih neprilika, 12. veljače 1945. godine napustile su Senj i otišle u kuću maticu u Zagreb. Istu ulogu imale su sestre u Bogoslovskom sjemeništu od 1898. do 1919. godine, kada je ono zatvoreno. Godine 1933. na mjesto milosrdnica došle su sestre Presvetog Srca Isusova.

Sestre su 1906. godine počele raditi u Gradskoj bolnici ili Domu starih. Zaposlene su bile četiri sestre. Kada je stara bolnička zgrada 1932. godine srušena da bi se napravila nova, sestre su prestale raditi uz dobiveno obećanje da ce ih se pozvati kada bolnica bude osposobljena. Međutim, kada je nova bolnica sagrađena, dovedene su u nju sestre Presvetog Srca Isusova. Sestre milosrdnice su se potužile na takav postupak i 1938. godine preuzimaju prijašnje obveze u bolnici. Je li to plod njihove pritužbe ili se nešto drugo dogodilo što je bio razlog odlaska sestara Presvetog Srca Isusova? Ove su se, naime, sestre tužile na postupak ravnatelja bolnice Polačeka i u njegovom postupku vide glavni razlog napuštanja bolnice. ${ }^{348}$ Nakon što su za njih nastupili nepodnošljivi ratni uvjeti,

${ }^{348}$ D. MLAKIĆ, 1999, 183-185. 
12. siječnja 1944. godine svih šest sestara, koje su radile u bolnici, napustile su bolnicu i Senj.

\section{b) Družba sestara Presvetog Srca Isusova}

Od ženskih redovničkih zajednica najprisutnije su bile u Senju sestre (Presvetog) Srca Isusova. Njihov dolazak u Senj dogodio se 1933., a odlazak iz Senja 1997. godine (djelovale su u Senju 64 godine). Tijekom tog razdoblja vodile su domaćinstvo u Biskupskom sjemeništu (1933. - 1940), radile su u banovinskoj bolnici u Senju (1935. - 1938.), vodile dječje obdanište (1939. - 1943.), radile u Konviktarskom vrtu (1960. - 1970.), vodile domaćinstvo u Biskupskom domu (1963. - 1969.) i župnom stanu (1947. - 1997.), a u katedrali su dugo vodile orguljašku, sakristansku i vjeroučiteljsku službu. Nakon uspostave samostalne hrvatske države predavale su vjeronauk u školi.

Družba sestara Presvetog Srca Isusova razvila se iz katoličke udruge Kćeri Srca Isusova koju je u Trstu 1879. godine osnovao o. Arcangelo da Camerino, franjevac kapucin, u suradnji s nekoliko djevojaka, među kojima je bila i Marija Kozulić, kasnije utemeljiteljica Družbe. Marija Kozulić rođena je u Rijeci 20. rujna 1852. godine. Vrativši se iz Trsta u svoj rodni grad Rijeku, osniva ondje 1895. godine Zavod Presvetog Srca Isusova za žensku mladež i dječji vrtić. Zajedno sa svojim suradnicama živi redovničkim životom. Napisala je za njih redovničke konstitucije koje je 6. srpnja 1899. godine odobrio senjsko-modruški biskup Antun Maurović. Naglasak nove redovničke zajednice je na brizi za napuštenu djecu i napuštenu mladež. Nova redovnička zajednica posvećena je Srcu Isusovu. O tomu kako je Rijeka prihvatila Družbu, podosta govori i naziv koji se uobičajio za Mariju Kozulić - "Riječka majka". Ona je svojem krsnom imenu dodala i redovničko "Krucifiksa". Sjedište Družbe bilo je u ulici Pomerio u zgradi koja se i danas naziva Sakrakor (Sacro Cuore). Godine 1914. sestre su otvorile prvu filijalu izvan Rijeke, u Risiki na otoku Krku. Tu su se skrbile za djecu i mladež poučavajući ih domaćinskim poslovima. Kasnije se krčki biskup Antun Mahnić zauzeo da ostanu ondje.

Nakon Prvog svjetskog rata sudbina sestara ovisila je o političkom rješenju pripadnosti Rijeke. Kada je Rijeka pripala Italiji, devet sestara Hrvatica odlazi na područje novoosnovane Države SHS i živi najprije kratko vrijeme u Risiki i Vrbniku. Tako nastaje hrvatski ogranak sestara. Posredovanjem Vladimira Nazora dolaze one u Dječji dom u Crikvenicu gdje je Nazor bio ravnatelj. Utemeljiteljica Marija Krucifiksa Kozulić umrla je u Rijeci 29. rujna 1922. godine, a upravu talijanskog ogranka u Rijeci preuzima njezina sestra Irena. 


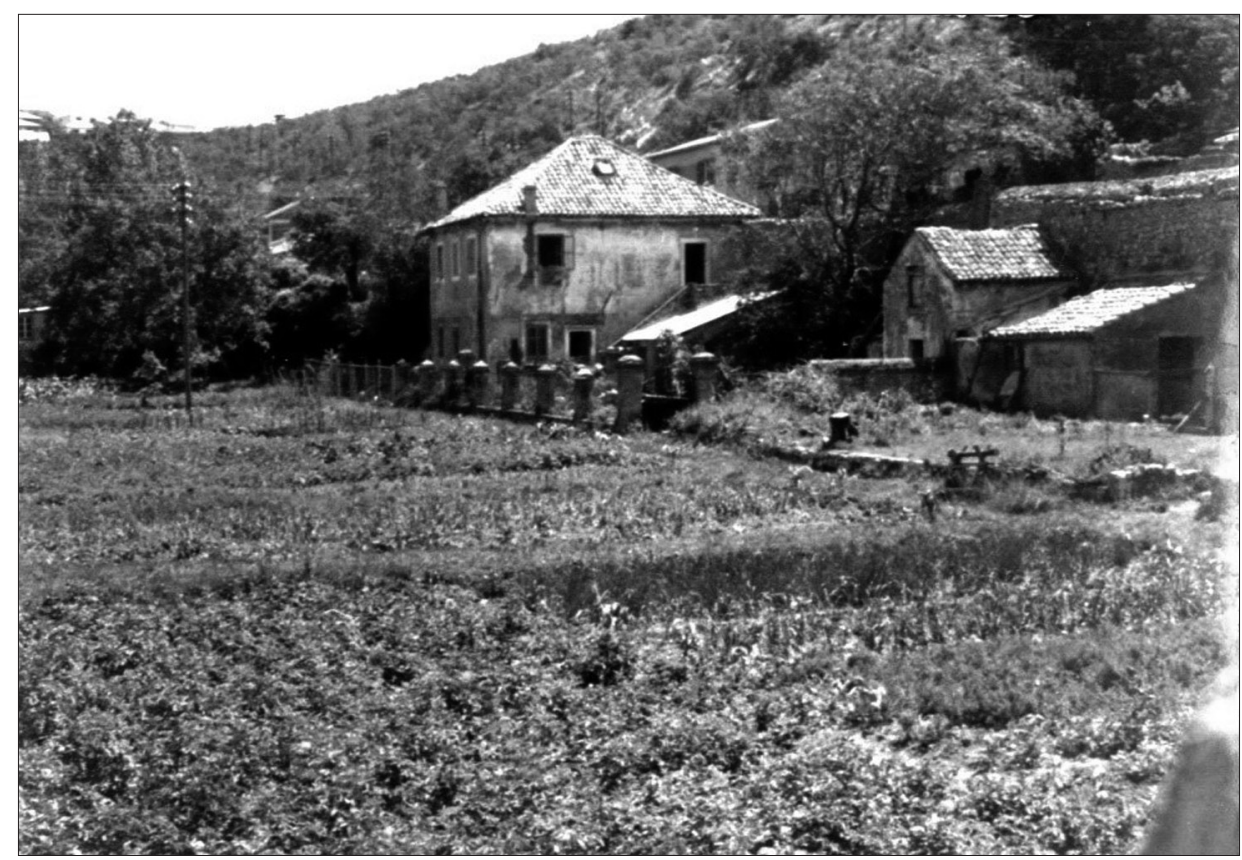

S1. 39. Sjemenišna kuća s vrtom na Travici (izvor: Sakralna baština Senj)

Hrvatske sestre kupile su 1927. godine kuću u Crikvenici. Kada je Rijeka nakon Drugog svjetskog rata vraćena Hrvatskoj, hrvatske sestre preuzele su i kuću talijanskih sestara u Rijeci koje su otišle u Italiju. Godine 1971. preneseno je sjedište iz Crikvenice u Rijeku, najprije u staru kuću maticu u ulici Pomerio, a kada je 1975. izgrađena samostanska kuća na Drenovi, sjedište Družbe prešlo je onamo.

U Senj je sestre prvi pozvao biskup Ivan Starčević 1933. godine da preuzmu vođenje kućanstva u sjemeništu. ${ }^{349}$ Najprije su došle tri sestre i jedna kandidatica, a ubrzo su došle još dvije sestre i još jedna kandidatica jer dotadašnji broj nije dostajao za onoliki posao. Biskup se pobrinuo da sestre reguliraju svoj status kao redovnice jer to nakon odvajanja od talijanskih sestara u Rijeci nije bilo crkveno-pravno riješeno. Godine 1934. dekretom Svete kongregacije za redovnike pobožna bratovština sestara postaje redovnička zajednica biskupskog prava. Sestre su dobile na korištenje i sjemenišnu kuću na Travici gdje su spavale

${ }^{349}$ O djelovanju sestara u Senju v. Dobroslava MLAKIĆ, Družba sestara Presvetog Srca Isusova, Zagreb - Rijeka, 1999, 180-192. 

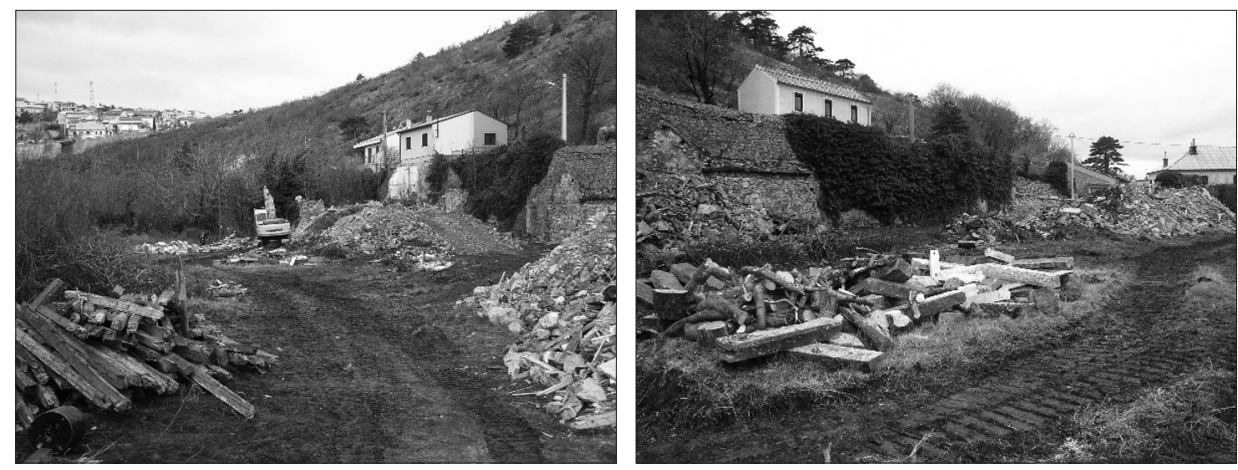

Sl. 40. a) i b) Travica, radovi na izgradnji Doma umirovljenika, 2011.

(foto: B. Ljubović)

jer nije bilo mjesta u sjemeništu. Kada je sjemenište 1940. godine zatvoreno, sestre su spremile dosta sjemenišnog inventara na čuvanje u kući na Travici. Ondje je bio tzv. Sjemenišni vrt koji su i dalje obrađivale.

$\mathrm{Na}$ Travicu se uselio i preč. Josip Banić kada je 1947. godine imenovan senjskim župnikom. Od tada su sestre vodile i župnikovo domaćinstvo. Redovito su na Travici bile dvije sestre i dvije kandidatice. Kada je Banić 1963. umirovljen, vodile su brigu o njemu sve do smrti 1973. godine. Uz to, sestre su se brinule za čišćenje katedrale, župne crkve, a pomagale su također, u župnoj katehizaciji.

Banićev nasljednik na župi, Josip Frković, nastanio se na drugom katu stambene zgrade u ulici Marka Balena br. 3 (u produžetku nekadašnje Crkve sv. Duha). Ondje je bio i župni ured. Župnik je dobio dvije sestre Srca Isusova kao pomoćnice u vođenju kućanstva.

Kada je 1969. godine biskup Burić postao prvi nadbiskup novoosnovane Riječko-senjske nadbiskupije, on se s kancelarijom i drugim biskupskim uredima preselio u Rijeku. Dotadašnja biskupijska zgrada u Senju postala je župni stan u koji su se, pored župnika, preselile i sestre kao domaćice, katehistice i orguljašice te su ondje bile do 1997. godine.

Pet sestara počele su 1. travnja 1935. godine raditi u banovinskoj bolnici u Senju. Sestre milosrdnice potužile su se senjskom biskupu da bi one trebale imati prednost kod zapošljavanja u bolnici. Naime, milosrdnice su radile u staroj bolnici, a kada je ona srušena dobile su obećanje da će ih pozvati kada se izgradi nova bolnica. Međutim, u novosagrađenu bolnicu 1935. godine primljene su sestre Presvetog Srca Isusova. One su otišle iz bolnice 1938. godine i došle su milosrdnice. Nije jasno jesu li milosrdnice došle jer je uvažena njihova žalba ili je uprava bolnice na čelu s dr. Polačekom dala otkaz sestrama Presvetoga Srca 
Isusova, a pozvala milosrdnice. Svakako se Sestre Presvetoga Srca Isusova tuže da im je dr. Polaček bio nenaklon, pa su one 30. travnja 1938. godine napustile rad u bolnici.

Od 1939. do 1943. godine sestre su radile u Dječjem obdaništu uz tvornicu duhana na Staroj cesti. Čini se da je to isto obdanište koje su prije držale sestre iz Družbe "Immaculata" i šibenske franjevke. Dvije sestre radile su kao odgajateljice, a jedna je bila zaposlena u kuhinji. U obdaništu su bila djeca radnica u tvornici duhana. Kada je 1943. godine zbog ratnih razaranja tvornica prestala raditi, zatvoreno je i obdanište. Od 1960. do 1970. godine sestre Presvetog Srca Isusova radile su na bivšoj ekonomiji zavoda "Ožegovićianum", u ulici Kajetana Knežića 4. Prije toga tu ekonomiju su držale šibenske sestre franjevke od Bezgrješne, a kada su one dale otkaz, biskup Burić je pozvao sestre Srca Isusova iz Crikvenice. Sestre su uzdržavale domaće životinje, uređivale voćnjak i obrađivale vrt za uzdržavanje biskupijskih ustanova i za svoje uzdržavanje. Vrt je 1970. godine prodan, a sestre su premještene na druga mjesta.

Nakon što je 1963. godine dovršena nova biskupska rezidencija u bivšoj Prepozituri (palača "Carina"), biskup i biskupijski uredi premješteni su iz samostana sestara franjevki u novu kuću, a kućanstvo preuzimaju sestre Srca Isusova. One su ondje ostale sve do preseljenja ordinarijata u Rijeku 1969. godine, kada je osnovana Riječko-senjska nadbiskupija sa sjedištem u Rijeci. Tada su i sestre Benigna Prelc i Helena Vučić otišle iz Senja. One su uz poslove domaćinstva odradile zahtjevan posao oko namještanja biskupskog doma i pomaganja u pripremanju novoga nedaleko toga, a s. Benigna je uz to i vodila crkveni zbor. U Senju su sestre Presvetog Srca Isusova u najtežim vremenima podmetnule svoja ramena i u manualnim poslovima i u pastoralu, ali su također, u svjedočenju svoje vjere u duhu karizme svoje Družbe, ostavile duboki trag u kršćanskom Senju.

\section{c) Franjevke}

\section{Samostan Družbe "Immaculata"}

Današnju zgradu na Staroj cesti br. 13 sagradila je 1744. godine porodica Domazetovića, kako to svjedoči ploča s natpisom i grbom iste obitelji. Domazetovići su starinom iz Bosne, a prebjegli su u Senj pred Turcima. Poslije Prvog svjetskog rata, zgradu je preuredio dr. Korewa u prvo zubarsko lječilište u Hrvatskoj i tada je ta barokna palača promijenila svoj izgled. Godine 1920. došle su sestre Družbe "Immaculata" ili "Maria" kojima je kuća matica bila u Rijeci. 
Shematizam Senjsko-modruške ili Krbavske biskupije navodi 1925. godine da one u Senju drže dječje obdanište ili zabavište. ${ }^{350}$ To su one držale i 1929. godine jer ih biskup Marušić u siječnju te godine preporučuje krčkom ordinarijatu da mogu po krčkim župama skupljati ulje za kućne potrebe. Obdanište je bilo za djecu majki koje su radile u tvornici duhana. ${ }^{351} \mathrm{Kad}$ su 1928. godine kupile spomenutu kuću na Staroj cesti, u nju su smjestile internat za žensku mladež ili Dom sv. Terezije Maloga Isusa za polaznice gimnazije. Na drugom katu samostana bila je kućna kapelica u čast sv. Terezije. ${ }^{352}$

Nakon smrti utemeljiteljice te redovničke družbe Terezije Herczeg 1929. godine, riječki biskup je dokinuo tu redovničku družbu jer nije imala svoj novicijat niti potrebnu materijalnu podlogu. ${ }^{353}$ Senjska filijala, jer nije podložna riječkom biskupu, nastojala je i dalje djelovati pod istim imenom, ali crkvene vlasti to nisu dopustile. Preporučile su sestrama da se uključe u neku od Crkve priznatu redovničku zajednicu. Najprije su to odbile i htjele i dalje djelovati kao kongregacija "Immaculata". Ordinarijat nije popustio jer nisu imale dovoljno uvjeta za to i jer ne provode pravi duhovni život. Pokazale su volju da se uključe u Družbu sestara Presvetog Srca Isusova, ali to nije dolazilo u obzir jer još nije bio riješen njihov crkveno-pravni status nakon razlaza s riječkim ogrankom. Tako je došlo do vezivanja uz šibenske franjevke.

\section{Samostan franjevki}

Senjski ordinarijat je zatražio od Šibenske biskupije svjedočanstvo o podobnosti kongregacije šibenskih franjevki. Biskup šibenski Jerolim Mileta 3. lipnja 1930. godine dao je pozitivni odgovor uz dodatak da sestre u Senju (Stanislava Šuljić, Jolanda Mandić i Bernarda Frolja) žele biti primljene u tu Družbu; traži suglasnost da se može uputiti molba u Rim. ${ }^{354}$ Kada su dobivena pozitivna izvješća, mogle su sestre doći u Senj. ${ }^{355}$

${ }^{350}$ Pod latinskim nazivom: "Sorores Charitatis Congregationis "Maria" in asylo Segniae. Tada su u tom dječjem obdaništu radile tri sestre. (Schematismus cleri... 1925, 40)

${ }^{351}$ BAS, Spisi 1929., br. 212.

${ }^{352}$ Zacijelo je bila želja osnivača "Terezianuma" da ustanova bude za gimnazijalke ono što je "Ožegovićianum" bio za gimnazijalce. Međutim, "Terezianum" je u tom smislu daleko od "Ožegovićianuma". U njemu je povremeno bilo nekoliko gimnazijalki, ali nikada se on nije razvio u instituciju koja ima svoje ustrojstvo i kućni red. To vrijedi i za vrijeme dok su "Terezianumom" upravljale članice kongregacije "Immaculata" i za vrijeme kada su njime upravljale šibenske franjevke.

${ }^{353}$ M. MEDVED, 2015, 104.

${ }^{354}$ BAS, Spisi 1930., br. 1313.

${ }^{355}$ BAS, Spisi 1930., br. 1247. 
Jedna i druga strana složile su se s prijedlogom Ordinarijata da se nekretnine prenesu na Družbu iz Šibenika. To su kat. čest. 490/518 u gradu Senju - kuća broj 41417/376 s dvorištem od 207 č. hvati, i čestica kat. br. $519 / 1$ - dvorište u predgrađu u površini od 87 č. hvati. ${ }^{356}$ Pet sestara iz Družbe "Immaculata" primljeno je u njihovu Družbu, s time da su trebale proći novicijat. Biskup Mileta odredio je petnaestodnevne duhovne vježbe. ${ }^{357}$ Filijala u Senju službeno je otvorena 27. studenoga 1930. godine. Dopuštenje za otvaranje novicijata u Senju izdao je kapitularni vikar mons. Ivan Starčević. On je također imenovao mons. Antuna Golika duhovnim upraviteljem i savjetnikom za sestre. ${ }^{358}$ Tako je uspostavljen samostan šibenskih sestara franjevki od Bezgrješne u Senju koje su nastavile djelatnost prijašnjih sestara. Golik je svoju službu vršio do kraja rata, a onda se morao skloniti u Italiju. Uz novicijat, franjevke su vodile i dječje obdanište (zabavište) i internat za žensku mladež ili Dom sv. Terezije Maloga Isusa za polaznice gimnazije. Učiteljice novakinja bile su s. Roža Lovrić (1930. - 1931.) i s. Marija Budiša (1931. 1937.; 1940. - 1944.). Otvaranjem novicijata u Senju nije dokinut onaj u kući matici u Šibeniku, tako da je Družba do 1944. godine, kada je senjski prestao djelovati, imala dva novicijata.

Senj je u Drugom svjetskom ratu teško stradao, a nije ni samostan ostao čitav. Kanonik Matija Glažar izvješćuje 5. lipnja 1945. godine o stanju samostana i sestara. Glažar iznosi sljedeće: "Dom sv. Terezije znatno je oštećen uslijed zračnih napadaja. Bomba doduše nije direktno pogodila kuće, no jedna je bomba pala u praonicu, a više njih na cestu pred kuću. Time je sama kuća pretrpjela osjetljivu štetu. Krov je izrešetan, polupani prozori, veliki dio plafona ispao. U kući zasad ne stanuje nijedna od časnih sestara. Preko dana borave u njoj sestre Augustina i Jelena, i paze na namještaj. Spavaju kod sestara Srca Isusova. Dvije sestre Terezija i Tomislava, vode kućanstvo preuzv. gosp. Biskupa koji, jer je biskupski dvor razrušen, stanuje izvan grada u jednoj privatnoj kući. Zbog bombardiranja sklonile su se časne sestre predstojnica, Petronila i Antonija na Vratnik i dobile jednu sobu u župnom stanu. Tu je sestra predstojnica i umrla. Druge dvije sestre (Petronila bolesna) su još i sada na Vratniku, no stanuju u jednoj seljačkoj kući. Tri sestre otišle su otišle u Ogulin (Rafaela, Ivana i Frana) voditi kućanstvo u jednom zavodu. Sada preuzeše kuhinju u jednoj menzi, a spavaju u župnom 366-367.

${ }^{356}$ BAS, Spisi 1930., br. 2898; Majka Klara Žižić i njezina družba 1706. - 2006., 2009,

${ }^{357}$ BAS, Spisi 1930., br. 2900.

${ }^{358} \mathrm{Ne}$ slažu se podaci kada su te ustanove proradile. 
stanu. Dvije sestre otišle su u Vrata u Gorskom kotaru i nastanile su se u kući mons. Golika." ${ }^{339}$

Nakon rata osposobljena je za stanovanje zgrada časnih sestara franjevki u Senju zvana "Terezianum", s tim da se u njoj privremeno smjesti biskup i biskupska kancelarija. Nakon što je popravljena i osposobljena za svoju funkciju senjska katedrala, počelo se misliti i na izgradnju biskupske kurije. Budući da na vrijeme nije mogla biti obnovljena teško oštećena kurija, ta je u međuvremenu ruševina s čitavim vrtom i gospodarskim zgradama bila 1958. godine eksproprirana u svrhu gradnje tvornice pokućstva Drvnoindustrijskog poduzeća Senj. U tim okolnostima smatralo se da je najjednostavnije rješenje - obnoviti bivšu kuriju senjskog prepošta ("Prepozituru"). ${ }^{360}$ Kada je obnova dovršena, biskup se s ordinarijatom preselio od sestara franjevki u obnovljenu zgradu u kojoj je domaćinstvo povjereno sestrama Presvetoga Srca Isusova.

Konvikt "Ožegovićianum" imao je svoje gospodarstvo u Ulici Kajetana Knežića br. 3. Kada je konvikt zatvoren, gospodarstvo je došlu pod izravnu upravu Biskupije koja je gospodarstvo povjerila sestrama franjevkama kod kojih se poslije rata biskup sa svojim uredima nastanio. Sestre su radile u vrtu do 1960. godine. ${ }^{361}$ Budući da su neke oboljele, a nije bilo drugih da ih zamijene, sestre su spomenute godine otkazale brigu za vrt. Ordinarijat je tada poslao onamo sestre Srca Isusova. ${ }^{362}$ Time se otvorilo pitanje potreba i smisao daljnjeg ostanka sestara franjevki u Senju. One su otprije radile na tome da dobiju prikladnu kuću u Zagrebu. Da bi mogle sagraditi u Zagrebu pogodnu kuću i na pristupačnom mjestu, prodane su druge nekretnine u Zagrebu i kuća u Senju. ${ }^{363}$ Tako su 1964. godine sestre, nakon 34 godine rada i djelovanja, napustile Senj.

Sestre su od 1959. godine interdijecezanska redovnička zajednica jer su se proširile izvan Šibenske biskupije. ${ }^{364}$ Tijekom cijelog razdoblja svoga boravka u Senju sestre su bile uključene na razne načine u župni pastoral. S. Petronila C̆ugura vodila je katedralni zbor u Senju od 1952. do 1964. godine. ${ }^{365}$

${ }^{359}$ BAS, Spisi 1945., br. 98. Mons. Golik je svoju kuću u Vratima preuredio za dječje zabavište i u nju doveo sestre milosrdnice. One su zbog ratnih nevolja 1942. godine napustile kuću. U tu su se, dakle, kuću sklonile sestre iz Senja.

360 Službeni vjesnik, 1964, br. 1, 18.

${ }^{361}$ D. MLAKIĆ, 1999, 186.

${ }^{362}$ BAS, Spisi 1960., br. 1040: Franjevke 9. listopada 1960. godine otkazuju rad u vrtu, a 5. studenoga ordinarij odgovara da će ga idućeg tjedna preuzeti sestre Srca Isusova.

${ }^{363}$ Majka Klara Žižić i njezina družba 1706. - 2006., 2009, 401.

${ }^{364}$ Majka Klara Žižić i njezina družba 1706. - 2006., 2009, 366-370, 391, 394.

${ }^{365}$ Majka Klara Žižić i njezina družba 1706. - 2006., 2009, 644-645. 


\section{Dom sv. Terezije ili "Terezianum"}

U drugom dijelu 19. stoljeća i u prvom dijelu 20. stoljeća nastaju u katoličkim zemljama mnoge redovničke zajednice koje vode brigu o djeci i mladeži. Naime, industrijska revolucija izvlačila je mnoge ljude iz okružja vlastite obitelji i djeca i mladež nisu više mogli dobiti onaj odgoj koji je davala stabilna obitelj. To se osjetilo i u Rijeci u fazi njezinog jakog industrijskog razvoja. Crkva je odgovarala kroz redovničke zajednice. U Rijeku dolaze salezijanci, a nastaju i dvije ženske redovničke zajednice: Sestre Srca Isusova i Družba "Immaculata" (od Bezgrješne) koju je osnovala Terezija Herczeg. S tom idejom dolaze u Senj 1920. godine sestre iz Družbe "Immaculata". Kad su kupile kuću u Senju osnovale su dječje obdanište i internat za gimnazijalke koje su nazvale Dom sv. Terezije ili "Terezianum".

Očito je da je ta ustanova željela davati gimnazijalkama ono što je "Ožegovićianum" pružao gimnazijalcima. Nemamo podataka kako je ta nova ustanova funkcionirala. Ponuda je bila izazovna pa je zacijelo bilo i gimnazijalki koje su ponudu prihvatile. No, ta ustanova se u to vrijeme borila za svoj opstanak pa je teško vjerovati da je složeni odgojiteljski posao u takvim okolnostima mogao biti na visokoj razini. Još gore je bilo kada je riječki biskup zabranio daljnje djelovanje Družbe nakon što je 1929. godine umrla njezina utemeljiteljica. Da bi mogle nastaviti redovnički živjeti i djelovati, dogovorile su se sestre da će na šibenske sestre Trećeg reda sv. Franje ili od Bezgrješne prenijeti svoju imovinu, a one će ih primiti u svoju Družbu. Nakon nekoliko godina šibenske sestre otvaraju u Senju i dječje zabavište (obdanište) i "Terezianum". Pavao Tijan zabilježio je još 1931. da sestre u Senju vode obdanište ${ }^{366}$, a Biskupska kancelarija u Senju izdala je 20. kolovoza 1966. godine uredovnu potvrdu da je u Senju postojao i djelovao đački internat za srednjoškolsku žensku mladež pod imenom "Terezianum" i to od 1933. godine do konca Drugog svjetskog rata. Spomenuti internat bio je vlasništvo časnih sestara franjevki, a bio je registriran kod građanskih vlasti i imao dozvolu djelovanja. ${ }^{367} \mathrm{U}$ zborniku sestara pak navodi se da su sestre 1934. godine otvorile u Senju dječje zabavište i internat za gimnazijalke pod imenom Dom sv. Terezije, tzv. "Terezianum". ${ }^{368} \mathrm{Za}$ tu ustanovu imamo podatke da je kroz nju prošao veći broj gimnazijalki i da je imala svoja pravila odobrena od crkvene vlasti. Prema nekim podacima ta ustanova djelovala je sve do 1948. godine, kada je državna vlast zabranila crkvenim institucijama da

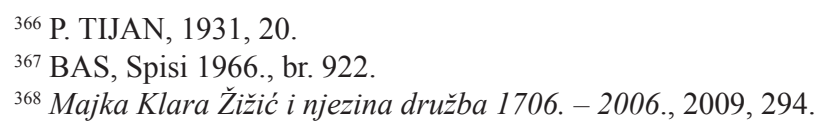




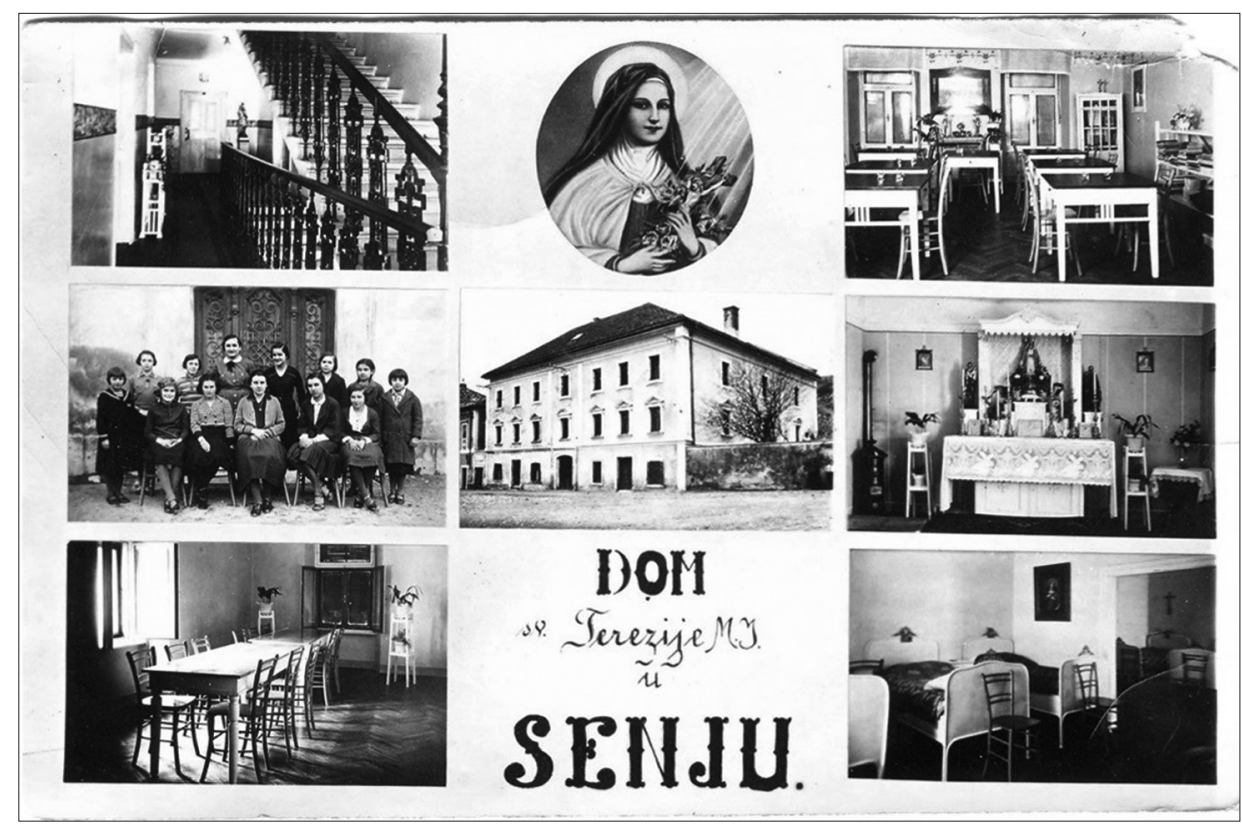

Sl. 41. Dom sv. Terezije ili "Terezianum" (izvor: Sakralna baština Senj)

drže odgojne zavode, osim za đake koji su se opredijelili za crkvena zvanja. Ako je do te godine i bilo gimnazijalki u Domu, moglo se raditi o malom broju jer je u istoj kući bio i Biskupski ordinarijat.

\section{Zaključak}

Redovništvo se u Crkvi u obliku organiziranih zajednica javlja poslije 313. godine. Nakon podjele kršćanstva na Zapad i Istok, na Katoličku i Pravoslavnu Crkvu, redovništvo na senjskom području ostalo je vjerno Zapadu, a od Istoka je baštinilo glagoljicu i staroslavensko (starohrvatsko) bogoslužje. Od muških redovničkih zajednica među prvima se u Senju i okolici javljaju benediktinci (12. stoljeće) i osnivaju svoje opatije u Svetom Jurju, Senjskoj Dragi i iznad Senja. Godine 1183./4. u Senj dolaze i osnivaju svoj samostan templari. Od prosjačkih redova prvi dolaze franjevci, vjerojatno još u vrijeme biskupa Filipa. Prvi sigurni trag o njihovoj prisutnosti u Senju datira iz 1272. godine. Prema dostupnim podacima, znamo da su dominikanci došli u Senj 1378. godine. Najduže su se u Senju i okolici zadržali pavlini - od 1364. do 
1786. godine - sa svojim samostanima u Ljubotini (Spasovcu) kraj Senja, Vlaškoj dragi i u samom Senju. Augustinci su djelovali ovdje kratko vrijeme, od 1622./3. do 1632. godine. Nakon prestanka djelovanja muških redovničkih zajednica potkraj 18. stoljeća, na "duhovnu scenu" u Senju krajem 19. stoljeća dolaze ženske redovničke zajednice: milosrdnice (od 1896. do 1945. godine), Družba sestara Presvetog Srca Isusova (od 1933. do 1997. godine), Družba "Immaculata" (od 1920. do 1930. godine) i franjevke (od 1930. do 1964. godine). Potonje dvije zajednice vodile su u Senju đački internat za žensku mladež pod nazivom Dom sv. Terezije ili "Terezianum". Kontinuitet redovničkog života u Senju i okolici, još od 12. stoljeća, prekinut je 1997. godine odlaskom zadnjih časnih sestara.

Redovnici i redovnice nisu u Senju i okolici bili samo akteri na vjerskopastoralnom području, nego je njihov utjecaj bio eminentno prisutan na području odgoja, obrazovanja, gospodarstva i graditeljstva, a templarima je čak, povjerena i uprava nad Senjom. O životu i djelovanju tih redovničkih zajednica svjedoče brojni pisani tragovi, kao i kameni ostaci njihovih samostana i crkava.

\section{Literatura}

\section{Izvori}

Archivio Segreto Vaticano (ASV), Reg. vat., vol. 212, f. 359rv.

ASV, Reg. Lat., vol. 1058, 225v-228r.

ASV, Reg. Vat., vol. 353, f. 298v.

ASV, Reg. Vat., vol. 499, f. 226v-227r.

ASV, Reg. Vat., vol. 599, f. 226v-227r.

ASV, Registri Supplicantium, vol. 459, f. 52v-53r.

BAS, fasc. I B, br. 31 .

BAS, fasc. II B, br. 7 .

BAS, fasc. II, br. 14.

BAS, fasc. III B, br. 7 .

BAS, fasc. IX B, br. 41.

BAS, fasc. IX, br. 29, 30, 41.

BAS, fasc. V, br. 26.

BAS, fasc. VI B, br. 17.

BAS, fasc. VI, br. 23.

BAS, fasc. VIII B, br. 5 .

BAS, kutija I K, br. 1. 
BAS, Spisi 1873., br. 2157.

BAS, Spisi 1929., br. 212.

BAS, Spisi 1930., br. 1247, 1313, 2898, 2900.

BAS, Spisi 1945., br. 98.

BAS, Spisi 1960., br. 1040.

BAS, Spisi 1966., br. 922.

Biskupski arhiv Gospić, Spisi 2009., br. 71.

Biskupski arhiv Senj (BAS), F I, 49 B.

Kamilo DOČKAL, Građa za povijest pavlinskih samostana u Hrvatskoj. Rukopis u Arhivu HAZU pod sign. XVI 29a.

Državni arhiv Zadar, Sudski arhiv u Rabu, Acta de Stantiis, 326-327.

Historijat i inventar župne crkve u Puntu, 1956.

Hrvatski državni arhiv, Generalcommando Karlovac, kut. 14, br. 17.

Hrvatski državni arhiv, Pavlinski samostani, Conv. B. Nicolai de nemore Modrussiensi.

Hrvatski državni arhiv, Pavlinski samostani, Conv. S. Helenae.

Hrvatski državni arhiv, Pavlinski samostani, Conventus S. Salvatoris.

Hrvatski državni arhiv, Pavlinski samostani, Razni samostani.

Kaptolski arhiv Senj, I, 22.

\section{Tiskani izvori}

Toma ARHIĐAKON, Historia Salonitana u: Franjo RAČKI (ur.), Zagrabiae, 1894.

Mile BOGOVIĆ, Senjsko-modruška ili Krbavska biskupija. Izvješća biskupa Svetoj Stolici 1602.-1919., Zagreb, 2003.

Arpad BOSSANY, Regesta supplicantionum, Klement papa 1342-1352, Budapest, 1916.

Bullarium Franciscanum, Nova series, IV/2, Grottaferrata, 1990.

Camera apostolica, I, Zagreb - Rim, 1996.

Camera apostolica, II, Zagreb - Rim, 2001.

Codex diplomaticus Regni Croatiae et Slavoniae, II, III, IV, V, VI, VII, VIII, X, XI, XII, Tadija SMIČIKLAS (ur.), Zagreb, 1904. - 1914.

Codex diplomaticus Regni Croatiae et Slavoniae, XIII, Marko KOSTRENČIĆ - Emilij LASZOWSKI (ur.), Zagreb, 1915.

Codex diplomaticus Regni Croatiae et Slavoniae, XV, Marko KOSTRENČIĆ (ur.), Zagreb, 1934.

Codex diplomaticus Regni Croatiae et Slavoniae, XVI, Marko KOSTRENČIĆ (ur.), Zagreb, 1976.

Codex diplomaticus Regni Croatiae et Slavoniae, XVII, Stjepan GUNJEČA (ur.), Zagreb, 1981.

Šime DEMO, Kanonske vizitacije Senjske i Modruške (Krbavske) biskupije. Personalne vizitacije župe Senj (18. stoljeće), Zagreb, 2007. 
Georgius FEJÉR, Codex diplomaticus Hungariae ecclesiasticus et civilis, IV/2, Budae, 1829.

Hrvatske glagoljične i ćirilične isprave iz zbirke Stjepana Ivšića 1100. - 1527., Acta croatica - Hrvatski spomenici, Josip BRATULIĆ (ur.), Zagreb, 2017.

Ivan KUKULJEVIĆ SAKCINSKI, Acta Croatica - Listine hrvatske, Zagreb, 1863.

Emilij LASZOWSKI, Monumenta Habsburgica Regni Croatiae, Dalmatiae, Slavoniae, III, Zagreb, 1917.

Radoslav LOPAŠIĆ, Spomenici Hrvatske krajine, I, Zagreb, 1883.

Radoslav LOPAŠIĆ, Spomenici Hrvatske krajine, II, Zagreb, 1885.

Radoslav LOPAŠIĆ, Spomenici Hrvatske krajine, III, Zagreb, 1889.

Paulus LUKCSICS, Diplomata Pontificum saec. XV, vol. II., Monumenta Hungariae Italica, Budapestini, 1938.

Šime LJUBIĆ, Listine o odnošajih izmedju južnoga slavenstva i Mletačke Republike, Knjiga 1, Zagreb, 1868.

Monumenta vaticana historiam regni Hungariae illustrantia, I/IV, Budapest, 1896.

Đuro ŠURMIN, Hrvatski spomenici, Zagreb, 1898.

Lajos THALLÓCZI-Samu BARABÀS, Codex diplomaticus comitum de Frangepanibus, 25, Budapest, 1910.

\section{Knjige i zbornici}

Slavica BABIĆ (ur.), Spomenica Sv. Jurja, Sveti Juraj, 2003.

Mile BOGOVIĆ (ur.), Krbavska biskupija u srednjem vijeku, Rijeka - Zagreb, 1988.

Mile BOGOVIĆ, Moji predšasnici biskupi u Senju, Otočcu, Krbavi, Modrušu, Vinodolu i Rijeci, Senj, 2017.

Mile BOGOVIĆ, Glagoljica - bitna odrednica hrvatskog identiteta, Zagreb, 2019.

Aleksandar BUCZYNSKI, Gradovi Vojne krajine, I, Zagreb, 1997.

Josip BURIĆ, Biskupije Senjska i Modruška u XVIII. stoljeću, Zagreb - Gospić, 2002.

Đurđica CVITANOVIĆ - Vladimir MALEKOVIĆ - Jadranka PETRIČEVIĆ (ur.), Kultura pavlina, Zagreb, 1989.

Daniele FARLATI, Illyricum sacrum, IV, Venetiis, 1769.

Daniele FARLATI, Illyricum sacrum, V, Venetiis, 1775.

Branko FUČIĆ, Glagoljski natpisi, Zagreb, 1982.

Branko FUČIĆ, Terra incognita, Kršćanska sadašnjost, Zagreb, 1997.

Francescus GLAVINICH, Origine della provincia Bosna Croatiae, Udine, 1648. (Pretisak: Rijeka, 2014.)

Franciscus GONZAGA, De origine seraficae religionis franciscanae, Roma, 1587.

Hrvatski kulturni spomenici 1, Senj, Zagreb, 1940.

Nada KLAIĆ, Izvori za hrvatsku povijest do 1526. godine, Zagreb, 1972.

Nada KLAIĆ, Vinodol od antičkih vremena do knezova Krčkih i Vinodolskog zakona, Pazin - Rijeka, 1988. 
Vjekoslav KLAIĆ, Krčki knezovi Frankapani, Rijeka, 1991.

Ljudevit KRMPOTIĆ, Izvještaji o utvrđivanju granica Hrvatskog kraljevstva od 16. do 18. stoljeća, Hannover - Karlobag - Čakovec, 1997.

Ivan KUKULJEVIĆ SAKCINSKI, Putne uspomene iz Hrvatske, Dalmacije, Arbanije, Krfa i Italije, Zagreb, 1873.

Ivan KUKULJEVIĆ SAKCINSKI, Nadpisi sredovječni i novovjeki na crkvah i javnih $i$ privatnih sgradah u Hrvatskoj i Slavoniji, Zagreb, 1891.

Krešimir KUŽIĆ, Hrvati i križari, Zagreb, 2003.

Mile MAGDIĆ, Topografija i poviest grada Senja, Senj, 1877.

Lujo MARGETIĆ, Bašćanska ploča, 2. dopunjeno izdanje, Povijesno društvo Rijeka i Vitagraf, Rijeka, 2000.

Mirjana MATIJEVIĆ SOKOL - Tomislav GALOVIĆ - Ivan BOTICA, Privilegia fundationis monasterii sanctae Mariae Czriqueniczae - Fundacijske isprave samostana svete Marije u Crikvenici, Grad Crikvenica, Crikvenica (izvršni nakladnik Glosa d.o.o. Rijeka), 2008.

Marko MEDVED, Riječka Crkva u razdoblju fašizma: nastanak biskupije i prvi talijanski upravitelji, Zagreb, 2015.

Dobroslava MLAKIĆ, Družba sestara Presvetog Srca Isusova, Zagreb - Rijeka, 1999.

Ivan OSTOJIĆ, Benediktinci u Hrvatskoj i ostalim našim krajevima, sv. II, Split, 1964.

Stjepan PAVIČIĆ, Seobe i naselja u Lici - Zbornik za narodni život i običaje južnih Slavena, Zagreb, 1962.

Pavao RITTER VITEZOVIĆ, Kronika aliti spomen vsega svieta vikov, Zagreb, 1696. (Pretisak, Zagreb, 2015.)

Petar RUNJE, Tragom stare ličke povijesti, II. izdanje, Ogulin, 2007.

Petar RUNJE, Prema izvorima, Provincijalat franjevaca trećoredaca (Novo i staro, knj. 2), Zagreb, 1990.

Petar RUNJE, Prema izvorima II. Rasprave i članci o hrvatskim franjevcima trećoredcima glagoljašima, Povijesno društvo otoka Krka, Krk - Zagreb (Krčki zbornik, sv. 68. Posebno izdanje, sv. 61.) i Provincijalat franjevaca trećoredaca glagoljaša (Biblioteka Novaja i vethaja, knj. 9), 2012.

Schematismus Cleri Dioecesium Segniensis et Modrušiensis seu Corbaviensis pro anno 1915., Segniae, 1915.

Schematismus cleri dioecesium Segniensis et Modrušiensis seu Corbaviensis et administrature apostolicae pro Castua eiusque territorio pro anno 1925., Segniae, 1925.

Manoilo SLADOVIĆ, Povesti biskupijah Senjske i Modruške ili Krbavske, Trst, 1856. (Pretisak: Gospić, 2003.)

Franjo ŠANJEK, Crkva i kršćanstvo u Hrvata, sv. I, Srednji vijek, Zagreb, 1988.

Franjo ŠANJEK, Dominikanci i Hrvati: osam stoljeća zajedništva (13. - 21. stoljeće), Kršćanska sadašnjost, Dominikanska naklada Istina, Zagreb, 2008.

Pavao TIJAN, Senj - kulturno-historijska šetnja gradom, Zagreb, 1931. 
Johann Weichard de VALVASOR, Die Ehre des Hertzogthums Crain, IV, Laibach (Ljubljana), 1689.

Melita VILIČIĆ, Arhitektonski spomenici Senja, Rad JAZU, Knjiga 360, Zagreb, 1971.

Vjestnik Kr. hrvatsko-slavonsko-dalmatinskog zemaljskog arkiva, 2, Zagreb, 1900.

Berislava VRAČIĆ - Alfonza KOVAČIĆ, Sestre milosrdnice II., Zagreb, 1998.

Terezija ZEMLJIĆ (ur.), Majka Klara Žižić i njezina družba 1706. - 2006., Šibenik, 2009.

Marijan ŽUGAJ, I conventi dei Minori Conventuali tra $i$ Croati dalle origini fino al 1500., Roma, 1989.

\section{III. Članci}

Anđelko BADURINA - Tomislav GALOVIĆ, Sv. Dujam i sv. Anastazije u hagiotopografiji Hrvatske, u: Joško BELAMARIĆ - Bratislav LUČIN - Marko TROGRLIĆ - Josip VRANDEČIĆ (ur.), Splitska hagiografska baština: povijest, legenda, tekst (Zbornik radova s međunarodnog znanstvenog skupa održanog u Splitu od 26. do 27. rujna 2011.), Split, Književni krug Split (Biblioteka Knjiga Mediterana 76) i Odsjek za povijest Filozofskog fakulteta u Splitu (Prinosi i rasprave / Contributiones et studia 4), 2014. 415-439 + 2 zemljovida, 1 grafikon, 11 slika.

Radojica F. BARBALIĆ, Brodarstvo u Senju i Podgorju kroz prošlost, Senjski zbornik, 4, Senj, 1970, 5-32.

Josip BARBARIĆ, Građa za povijest Krbavske biskupije u Arhivu Hrvatske, u: Krbavska biskupija u srednjem vijeku (Zbornik radova znanstvenog simpozija u povodu 800. obljetnice osnutka krbavske biskupije, održanom u Rijeci od 23. do 24. travnja 1986. godine), Rijeka - Zagreb, Visoka bogoslovska škola u Rijeci i "Kršćanska sadašnjost", 1988, 247-270.

Mile BOGOVIĆ, Crkvene prilike u Senju u 14. stoljeću i Statut Senjskog kaptola, Senjski zbornik, 15, Senj, 1988, 15-27.

Mihovil BOLONIĆ, Crkveni patronat na području Senjsko-modruške biskupije, Senjski zbornik, 5, Senj, 1973, 219-318.

Josip CHVALA, Crkva sv. Franje u Senju, Viesti društva inžinira i arhitekata, 15, br. 1, Zagreb, 1894, 1-2.

Damir DEMONJA, Prilog interpretaciji crkve Sv. Franje u Senju, Radovi Instituta za povijest umjetnosti, Zagreb, 22, 1998, 23-33.

Malyusz ELMER, A szlavoniai es horvätorszagi közepköri palos kolostrok oklevelei az Orsz. leveletarban, Leveltdri közlemenyek, III, 1925, 181-185 i 185-194.

Josip FRANČIŠKOVIĆ, Gdje je bila Opatija sv. Jurja?, Bogoslovska smotra, 15, br. 4, Zagreb, 1927, 489-492.

Josip FRANČIŠKOVIĆ, Crkva sv. Franje u Senju, Bogoslovska smotra, 19, br. 4, Zagreb, 1931, 411-423. 
Tomislav GALOVIĆ, Početci glagoljaštva Rogovske opatije, u: Tanja KUŠTOVIĆ Mateo ŽAGAR (ur.), Meandrima hrvatskoga glagoljaštva (Zbornik posvećen akademiku Stjepanu Damjanoviću o 70. rođendanu), Hrvatska sveučilišna naklada, Zagreb, 2016, 139-150.

Tomislav GALOVIĆ, Senjska ploča II. (neispisani kameni predložak), Senjski zbornik, 42-43, Senj, 2015-2016, 327-340.

Tomislav GALOVIĆ, "Sancti Gregorii monasterium, cui Urana est uocabulum", u: Božo DOŠEN (ur.), Braća Vranjani i vransko područje tijekom povijesti (Zbornik radova sa znanstvenog skupa Braća Vranjani i vransko područje tijekom povijesti održanog u Biogradu 25. travnja 2014.), Ogranak Matice hrvatske u Zadru, Zadar i Općina Pakoštane, 2017, 239-255.

Tomislav GALOVIĆ, Milan Moguš i Bašćanska ploča, Senjski zbornik, 45, Senj, 2018, 265-285.

Ante GLAVIČIĆ, Izvještaj o značajnim arheološkim nalazima u tvrđavi Nehaj u Senju, maja 1964. godine, Senjski zbornik, 1, Senj, 1965, 315-323.

Ante GLAVIČIĆ, Arheološki nalazi iz Senja i okolice, Senjski zbornik, 2, Senj, 1966, 383-426.

Ante GLAVIČIĆ, Arheološki nalazi iz Senja i okolice (II), Senjski zbornik, 3, Senj, 1968, 5-45.

Ante GLAVIČIĆ, Informacija za obnovu tvrđave "Nehaj" i izgradnju "Uskočkog mauzoleja" u gradu Senju 1972-1975 godine, Senjski zbornik, 4, Senj, 1970, 205-224.

Ante GLAVIČIĆ, Informacija o obnovi tvrđave Nehaj 1968-70 i izgradnji uskočkog mauzoleja u Senju, Vijesti muzealaca i konzervatora Hrvatske, 20, br. 1, Zagreb, 1971, 26-27.

Ante GLAVIČIĆ, Arheološki nalazi iz Senja i okolice (V), Senjski zbornik, 9, Senj, 1981-1982, 63-90.

Ante GLAVIČIĆ, Pregled starokršćanske i srednjovjekovne baštine Like, Podgorja i grada Senja, Senjski zbornik, 30, Senj, 2003, 21-82.

Ante GULIN, Pečati i grbovi grada Senja, Senjski zbornik, 20, Senj, 1993, 55-78.

Zorislav HORVAT, Srednjovjekovna pavlinska arhitektura na području Senjske i Modruško-krbavske biskupije, Senjski zbornik, 26, Senj, 1999, 123-178.

Zorislav HORVAT, Ruševna crkva na groblju sv. Filipa i Jakova u Sv. Jurju kraj Senja, Senjski zbornik, 28, Senj, 2001, 21-32.

Zorislav HORVAT, Pregled sačuvanih nadgrobnih ploča krčkih knezova Frankopana, Senjski zbornik, 32, Senj, 2005, 25-58.

Emanuel HOŠKO, Posljednji senjski franjevac, Marijin Trsat, 8, 1974, br. 3, 3-4.

Franjo Emanuel HOŠKO, Franjevci vode Senjsku gimnaziju na prijelazu iz 18. u 19. stoljeće, Senjski zbornik, 41, Senj, 2014, 277-292. 
Vjekoslav KLAIĆ, Darovnica Bele III (IV) krčkim knezovima za Senj jest patvorina, Vjestnik Kr. hrvatsko-slavonsko-dalmatinskog zemaljskog arkiva, 1, Zagreb, 1899, 263-274.

Slavko KOVAČIĆ, Ordini religiosi in Croazia durante il medioevo, u: Luciano VACCARO (prir.), Storia religiosa di Croazia e Slovenia, Centro Ambrosiano (Europa ricerche), Milano, ITL. spa, 2008, 221-232.

Slavko KOVAČIĆ, Sveti Benedikt i njegovo djelo u Crkvi i našem narodu (u povodu 1500. obljetnice rođenja sv. Benedikta), Crkva u svijetu, 4, 1980, 327-339.

Slavko KOVAČIĆ, Sveti Benedikt i njegovo djelo u Crkvi i hrvatskome narodu, u: Želimir PULJIĆ - Marijan SIVRIĆ (prir.), Benediktinci na području Dubrovačke nadbiskupije, Dubrovačka biskupija, Dubrovnik, 2010, 97-112.

Vladimir KRALJIĆ, Novi arhivski nalazi o glagoljskoj tiskari u Senjskoj Dragi, Senjski zbornik, 6, Senj, 1975, 77-80.

Vladimir KRALJIĆ, Benediktinska opatija Sv. Križa u Senjskoj Dragi, Senjski zbornik, 8, Senj, 1980, 325-328.

Stjepan KRASIĆ, Hrvatska dominikanska kongregacija (1508-1587), Bogoslovska smotra, 41, br. 2-3, Zagreb, 1971, 296-312.

Stjepan KRASIĆ, Regesti pisama generala dominikanskog reda poslanih u Hrvatsku (1392-1600), Arhivski vjesnik,17-18, Zagreb, 1974-1975, 157-246.

Stjepan KRASIĆ, Regesti pisama generala dominikanskog reda poslanih u Hrvatsku (1392-1600), Arhivski vjesnik, 21-22, Zagreb, 1978-1979, 201-321.

Branko KRMPOTIĆ, Benediktinci u gradu Senju i okolici, Senjski zbornik, 8, Senj, 1980, 318-324.

Ivan KUKULJEVIĆ SAKCINSKI, Priorat vranski sa vitezi templari i hospitalci Sv. Ivana u Hrvatskoj, Rad JAZU, 81, Zagreb, 1886.

Ivan KUKULJEVIĆ SAKCINSKI, Regesta documentorum regni Croatiae, Dalmatiae et Slavoniae saeculi XIII., Starine, 27, Zagreb, 1895, 1-168.

Juraj LOKMER, Katedrala Uznesenja Blažene Djevice Marije u Senju i senjski biskupi do početka XVII. stoljeća, Senjski zbornik, 42-43, Senj, 2015-2016, 235-326.

Blaženka LJUBOVIĆ, Inventarizacija i zaštita građe iz razrušene crkve sv. Franje u Senju i njezina buduća namjena, Senjski zbornik, 42-43, Senj, 2015-2016, 341-442.

Lujo MARGETIĆ, Senjski statut iz 1388., Senjski zbornik, 12, Senj, 1985-1987, 19-95.

Predrag MARKOVIĆ, Mramorni reljefi venecijanske radionice Bon u Senju i krčki knezovi Frankopani, Radovi Instituta za povijest umjetnosti, 30, Zagreb, 2006, 9-28.

Marko MEDVED, Augustinci pustinjaci u Senju, Senjski zbornik, 42-43, Senj, 20152016, 443-452.

Marija PANTELIĆ, Senjski Lobkowiczov glagoljski kodeks iz 1359. - prototip srednjovjekovnih "liber horarum" za laike, Senjski zbornik, 8, Senj, 1980, 355368 . 
Daniel PATAFTA, Franjevci u Senju - od konventualaca do opservanata, Senjski zbornik, 46, Senj, 2019, 137-158.

Andrija RAČKI, Stari samostani hrvatskog primorja, Katolički list, 1904, br. 31, 364 368.

Andrija RAČKI, Stari samostani hrvatskog primorja, Katolički list, 1904, br. 32, 374 377.

Franjo RAČKI, Pokret na slavenskom jugu koncem XIV. i početkom XV. stoljeća, Rad Jugoslavenske akademije znanosti i umjetnost, Knjiga III, Zagreb, 1868.

Službeni vjesnik, 1964, br. 1, 18.

Gjuro SZABO, Arhitektura grada Senja, Hrvatski kulturni spomenici 1, Senj, Zagreb, 1940, 35-52.

Ferdo ŠIŠIĆ, Rukovet spomenika o hercegu Ivanišu Korvinu i o borbi Hrvata s Turcima (1473-1496), Starine, 38, Zagreb, 1937, 1-180.

Luka ŠPOLJARIĆ, Hrvatski renesansni velikaši i mitovi o rimskom porijeklu, Modruški zbornik, 9/10, 2015-2016, 3-40.

Pavao TIJAN, Dominikanci u Senju i Senjskoj biskupiji, Kalendar Gospine krunice, 4, Zagreb, 1937, 67-71.

Pavao TIJAN, Grad Senj u povijesti i kulturi hrvatskog naroda, Hrvatski kulturni spomenici 1, Senj, Zagreb, 1940, 11-34.

Pavao TIJAN, Gdje je bila hiža arhižakna Silvestra Bedričića u kojoj je 1507./8. djelovala Senjska glagoljska tiskara, Senjski zbornik, 21, Senj, 1994, 109-116.

Marko TROGRLIĆ - Tomislav GALOVIĆ, Benediktinci u hrvatskoj historiografiji zadnjih 50 godina (1965. - 2015.), Služba Božja: liturgijsko-pastoralna revija, 58/4, 2018, 421-442.

Melita VILIČIĆ, Kakvu namjenu dati prostoru porušene crkve sv. Franje u Senju, Senjski zbornik, 4, Senj, 1970, 225-240.

\section{Internetski izvori}

SENJSKI SAMOSTANI, Senj - moj virtualni muzej, URL: https://www.facebook. com/2060876087281881/photos/a.2954223551280459/2954228464613301 (2021-7-11) 


\section{THE HISTORY OF MONASTICISM IN SENJ AND THE SURROUNDINGS}

\section{Summary}

Monasticism appeared in the Church as an organised community after 313, i.e. after Christianity gained freedom. In Croatia, monasticism was also influenced by the West and the East, the Western and Eastern Churches, i.e. the Catholic and Orthodox Churches. Monasticism in Senj and the surroundings remained faithful to the West, however, it inherited the Glagolitic script and Old Slavic (Old Croatian) worship from the Eastern heritage, due to which it played an important role of local, national and even global proportions. The Benedictines came to the Senj area in the $12^{\text {th }}$ century and had their abbeys in Sveti Juraj, Senjska Draga and Senj. The Templars also came to Senj in the $12^{\text {th }}$ century, the Franciscans a century later, and the Dominicans in the $14^{\text {th }}$ century. The Pauline monasteries in Ljubotina (today Spasovac) and Vlaška Draga (today Sveta Jelena) date from the $14^{\text {th }}$ century, and their presence in Senj itself was recorded in 1634 . Around 1622, the Augustinians operated in Senj for a short time. When it came to material support for the monks, the Frankopans stood out in particular, and after them were King Matthias Corvinus and his successors on the throne. Of the women's religious communities that appeared later, the activities of the Sisters of Charity (in the $19^{\text {th }}$ and $20^{\text {th }}$ centuries), the Sisters of the Sacred Heart of Jesus (in the $20^{\text {th }}$ century), the Sisters of the Immaculata (in the $20^{\text {th }}$ century) and the Franciscans (also in the $20^{\text {th }}$ century) were noted in Senj.

The religious communities in this area made a great contribution in a religious sense, as well as in education, the spread of literacy and culture, and the development of the economy and construction. With the departure of the Sisters of the Sacred Heart of Jesus from Senj in 1997, the thousand-year continuity of monastic life and work in Senj and its immediate surroundings was interrupted.

Keywords: Senj, monastic communities, monastery, church, Frankopans 